\title{
Ultrarövid impulzusok erősítése következő generációs titán-zafír lézerrendszerekben
}

\author{
Ph.D. értekezés
}

SZERZÖ:

\section{Nagymihály Roland Sándor}

TÉMAVEZETŐ

Dr. Börzsönyi Ádám

tudományos munkatárs

Szegedi Tudományegyetem, Optikai és Kvantumelektronikai Tanszék

TUDOMÁNYOS TANÁCSADÓ

Dr. Osvay Károly

egyetemi docens

Szegedi Tudományegyetem, Optikai és Kvantumelektronikai Tanszék

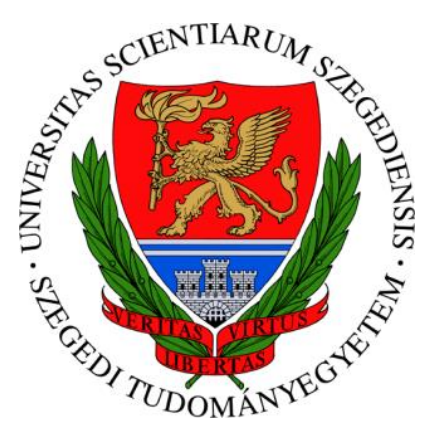

Fizika Doktori Iskola

Optikai és Kvantumelektronikai Tanszék

Természettudományi és Informatikai Kar

Szegedi Tudományegyetem

Szeged

2018 


\section{Tartalomjegyzék}

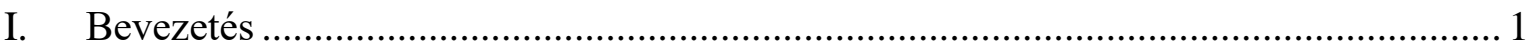

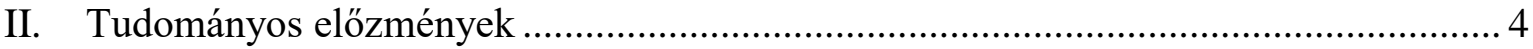

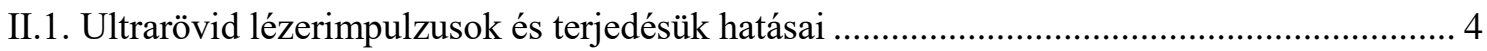

II.1.1. Komplex elektromos térerősség és a spektrális fázis .................................................... 4

II.1.2. Impulzusok terjedése lineáris optikai közegben ............................................................ 7

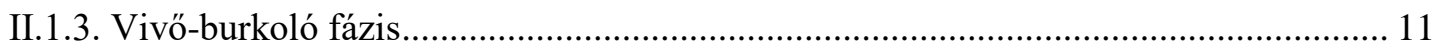

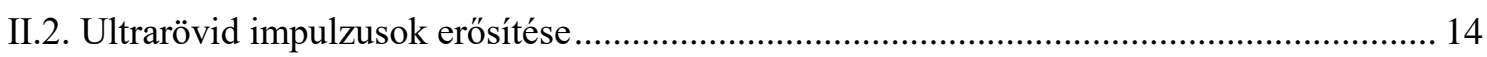

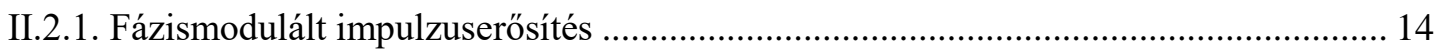

II.2.2. Ultrarövid impulzusok erösítése Ti:Sa kristályban .................................................... 16

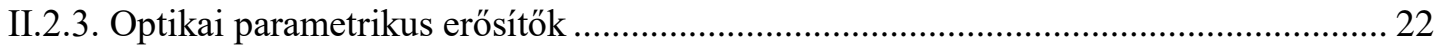

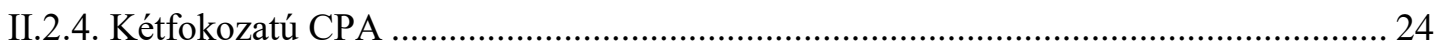

II.2.5. Polarizáció-kódolt fázismodulált impulzuserösítés ....................................................... 25

II.2.6. Átlagteljesítmény felskálázása koronglézerek segítségével ....................................... 27

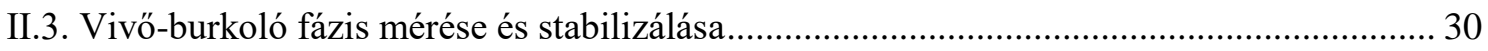

II.3.1. CEP-csúszás mérése: f-to-2f és 0-to-f interferometria .............................................. 30

II.3.2. Alrendszerek fáziscsúszásának mérése: spektrálisan bontott interferometria .............. 31

II.3.3. Spektrálisan bontott interferometria soksugaras interferométerrel ............................. 34

II.3.4. Abszolút CEP mérése: stereo-ATI .............................................................................. 34

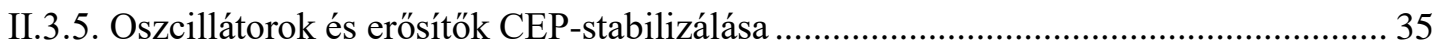

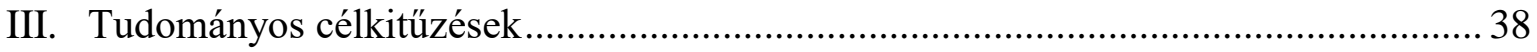

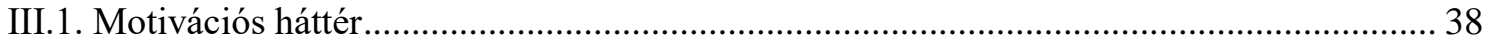

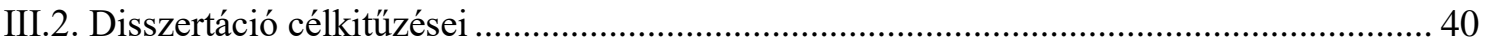

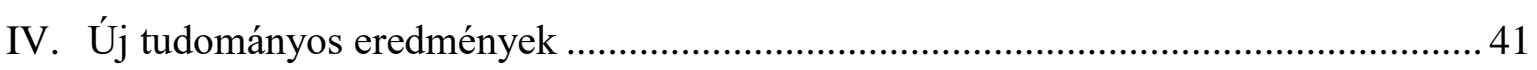

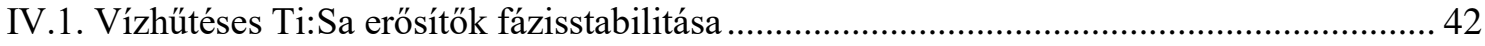

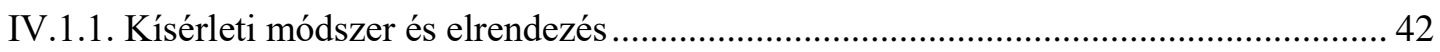

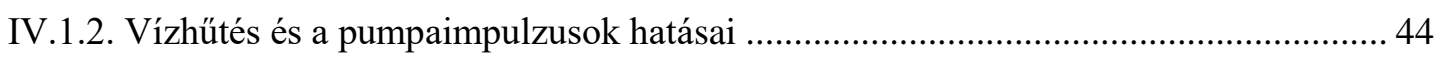

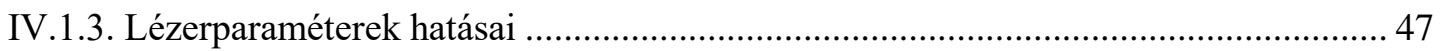

IV.1.4. Ismétlési frekvencia hatásának részletesebb elemzése .......................................... 49

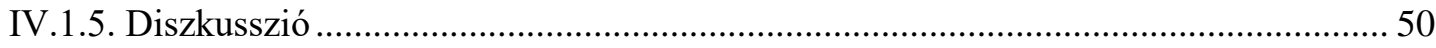

IV.2. Kriogenikus hütésủ Ti:Sa erősítők fázisstabilitása ..................................................... 52

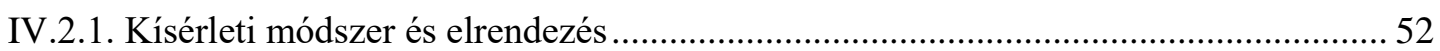

IV.2.2. Kiértékelési módszer és zajforrások azonosítása .......................................................5

IV.2.3. Vákuum- és hütőrendszer hatásainak mérése ….................................................. 57

IV.2.4. Ismétlési frekvencia és erösítés hatásai ................................................................... 58

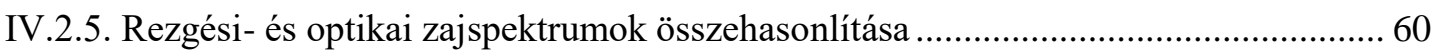


IV.2.6. Diszkusszió

IV.3. Ultranagy csúcsteljesítményü impulzusok előállítása Ti:Sa korongerősítőkben ................ 63

IV.3.1. Pumpálás közbeni energiakicsatolás korongerősítőben........................................... 64

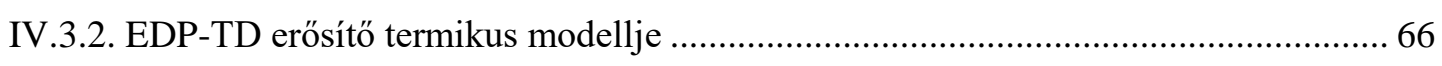

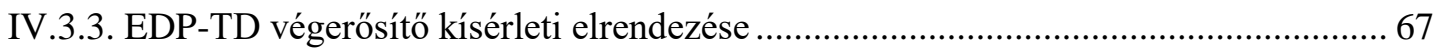

IV.3.4. Egylövéses erősítési kísérletek ................................................................................ 70

IV.3.5. 10 Hz-es pumpálás termikus hatása ..................................................................... 71

IV.3.6. Hullámfront torzulásának mérése …................................................................ 73

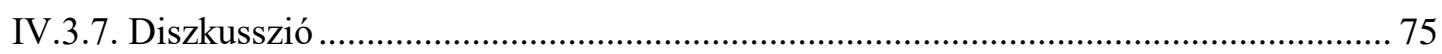

IV.4. EDP-TD végerősítők átlagteljesítményének felskálázása................................................. 76

IV.4.1. Vizsgált geometriák és lézerparaméterek ………...................................................... 76

IV.4.2. Kétdimenziós modell: hőmérsékleti peremfeltétel ................................................... 77

IV.4.3. Kétdimenziós részletes modell ......................................................................... 79

IV.4.4. Eredmények egycsatornás hütés esetére ………................................................. 80

IV.4.5. Eredmények kétcsatornás hütés esetére ................................................................... 83

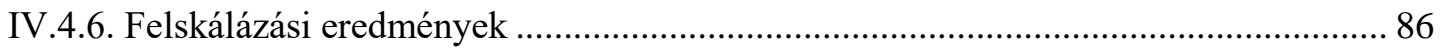

IV.4.7. Modell összehasonlítása a kísérleti eredményekkel ................................................. 88

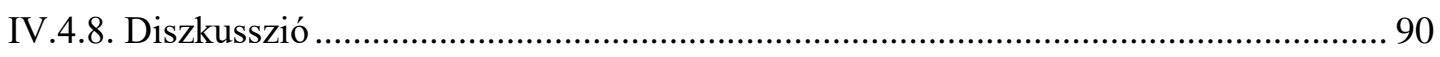

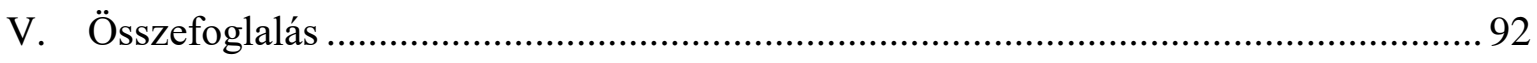

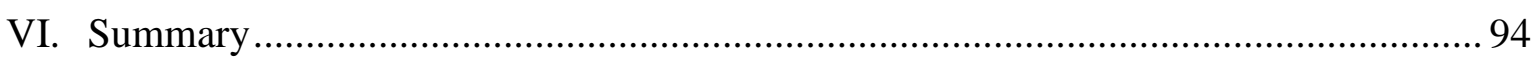

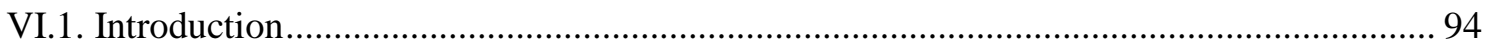

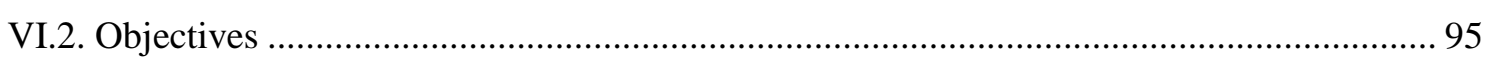

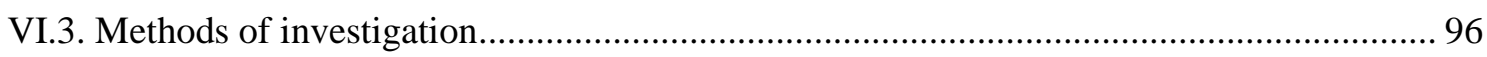

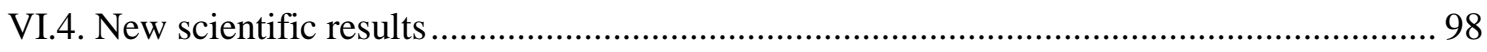

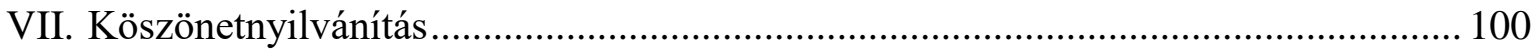

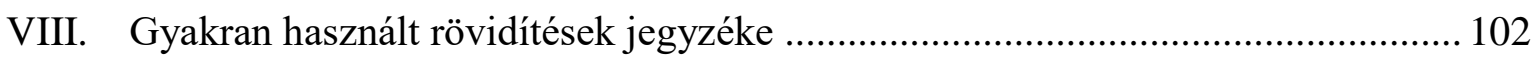

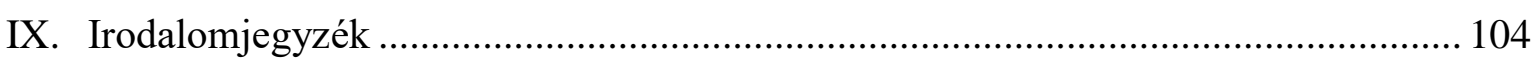

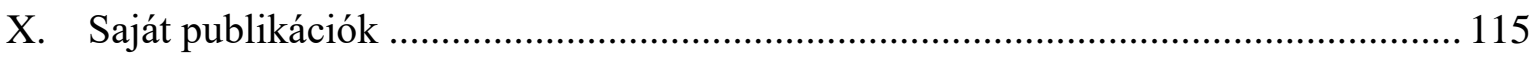

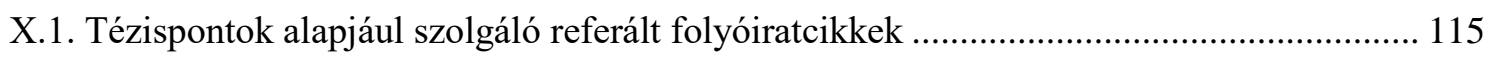

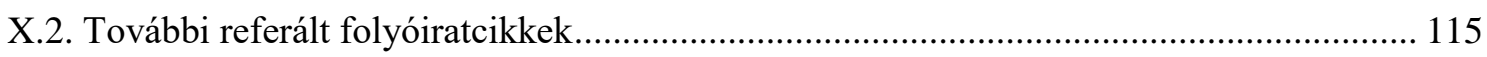

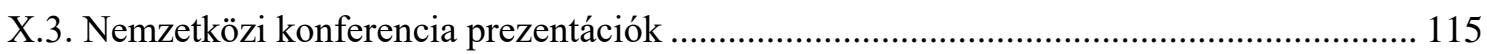

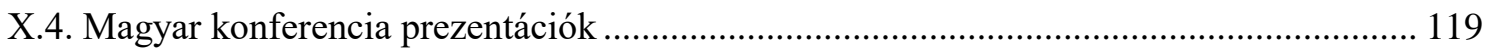

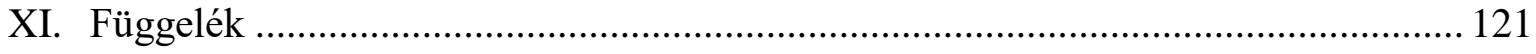

XI.1. Hőterjedés folyadékokban és szilárdtestekben ........................................................... 121

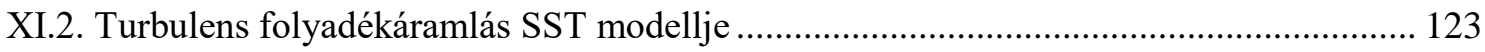




\section{Bevezetés}

Az emberiség a mérési precizitásban az utóbbi évszázad során óriási ugrást ért el. Mind az ipari, mind pedig a tudományos területeken nagy előrelépést jelentett a koherens fénynyalábok előállítására alkalmas lézer feltalálása [1], amely a precizitás egy új fokának felfedezését indította el. Ennek egyik kicsúcsosodása, hogy az Einstein által 1917-ben megfogalmazott indukált emisszióra vonatkozó elméletből eljutottunk a lézerek kutatásban, orvostudományban, sőt a mindennapokban való széleskörü használatához. A lézerek, mint potenciálisan nagy intenzitású koherens fénynyalábok előállítására alkalmas eszközök segítségével az anyag addig lineáris tartományba eső válaszától eltérő, nemlineáris effektusok kimutatása is lehetségessé vált. Számos elméleti munkát serkentettek ezek az újonnan felfedezett jelenségek, amelyek közül többre csak a közelmúltban volt lehetőség kísérleti bizonyítékot szerezni. Az ugyancsak Einstein által, 1916-ban megjósolt gravitációs hullámok létezésének kísérleti bizonyítékát 2016-ban, éppen száz évvel később a lézerek segítségével sikerült kimutatni [2]. A gravitációs hullámok interferometrikus módszerrel való detektálása egyike a fizika alapvető felfedezéseinek, és a mérési precizitás egyik csúcsát képviseli.

A rövid időskálán lejátszódó jelenségek megfigyelése a természet építőköveinek alapvető megértéséhez szükséges lépés a kutatók számára. Ehhez olyan rövid felvillanásokra van szükség, amelyek időtartama a vizsgált jelenségénél rövidebb, ezáltal feloldva azt. A lézerek fejlödésének egyik kulcsmomentumát ezért az ultrarövid (továbbiakban jellemzően az 1 ps alatti időbeli hosszúságú) impulzusok elóállítása jelentette ( $\left.1 \mathrm{ps}=10^{-12} \mathrm{~s}\right)$, amely megnyitotta az utat az olyan rövid természeti jelenségek megfigyelése felé, mint atomok és molekulák mozgása. Ezek a mozgások a femtoszekundumos ( $\left.1 \mathrm{fs}=10^{-15} \mathrm{~s}\right)$ időskálán játszódnak le, és ismeretük számos kémiai és biológiai jelenség megértéséhez alapvető fontosságú [3]. Az ultrarövid impulzusok előállítására elsőként szerves festékanyagokból álló aktív közegeket alkalmaztak, majd szilárdtesteken, gázokon, optikai szálakon, valamint félvezetökön alapuló elrendezésekkel is sikerült ultrarövid hullámcsomagokat generálni. Az energiatárolási képességek terén nyújtott teljesítményük, valamint kedvező fizikai tulajdonságaik miatt a szilárdtest alapú lézerek bizonyultak a legsikeresebbnek. Számos hordozó anyagot, jellemzően kristályokat használtak, amelyeket olyan fémionokkal adalékolva, mint az itterbium ( $\mathrm{Yb})$, titán (Ti), holmium (Ho), erbium (Er), vagy a túlium $(\mathrm{Tm})$, a láthatótól $(600 \mathrm{~nm})$ egészen a középinfravörös hullámhosszakig $(2 \mu \mathrm{m})$ értek el femtoszekundumos tartományba eső impulzusokat eredményező lézermüködést. A szilárdtest lézerek közül mind az ultrarövid impulzusok előállítására, mind pedig azok erôsítésére abszorpciós és emissziós sávjaik, illetve kiváló fizikai tulajdonságaik miatt a titán ionokkal adalékolt zafír ( $\mathrm{Ti}_{\mathrm{Al}} \mathrm{Al}_{2} \mathrm{O}_{3}$, továbbiakban $\boldsymbol{T i}: \mathrm{Sa}$ az angol Ti:Sapphire elnevezés után) kristályok lettek messzemenően a legsikeresebbek. Az ultrarövid impulzusok generálásukat követően az előállításhoz szükséges lézerelrendezés stabilitási megfontolásai miatt, jellemzően alacsony energiával rendelkeznek, amely számos alkalmazáshoz nem elegendő. Lehetőség van azonban az impulzusokban tárolt energia megnövelésére, amit optikailag pumpált lézererősítőkben szokás elvégezni. A lézererősítők segítségével ultranagy intenzitású elektromágneses tér állítható elö, amellyel a fény-anyag kölcsönhatás révén plazmát kelthetünk, továbbá akár elektron, vagy proton gyorsítást érhetünk el, valamint röntgen- illetve gamma impulzusokat is létrehozhatunk. Az így kapott sugárforrások nem csupán az alapkutatásban, de például az orvosi diagnosztikai és terápiás eljárásokban is kiemelt fontosságúak.

A legkorszerúbb lézerek segítségével néhány optikai ciklusból álló, több terrawatt $\left(1 \mathrm{TW}=10^{12} \mathrm{~W}\right)$, illetve megközelítőleg tíz optikai ciklusból álló és akár több petawatt $\left(1 \mathrm{PW}=10^{15} \mathrm{~W}\right)$ csúcsteljesítményü impulzusok állíthatóak elő. A fény tér- és időbeli lokalizációjának új szintre emelését 
a nagyintenzitású lézerek segítségével előállított, az elektromágneses spektrum extrém ultraibolya tartományába eső sugárzás felhasználásával sikerült elérni, amely révén megszületett az attoszekundumos tudomány ( 1 as $\left.=10^{-18} \mathrm{~s}\right)$. Az attoszekundumos időtartományba eső impulzusok segítségével megfigyelhetővé vált az elektronok molekulákban és atomokban való kollektív és individuális mozgása, amely széleskörü betekintést nyújtott például az ionizált gázokban és félvezetőkben bekövetkező elektroneloszlás-változásokra [3]. Ennek köszönhetően a nagyintenzitású, néhány ciklusú lézerimpulzusok napjaink egyik legfontosabb alkalmazása az izolált attoszekundumos impulzusok elóállítása. Ahhoz, hogy kontrollált módon tudjunk a lézertér és például nemesgázok kölcsönhatásából magasharmonikus sugárzást létrehozni, majd abból izolált attoszekundumos elektromostér-oszcillációkat nyerni, a keltő lézertér csúcsintenzitásának megléte nem elegendő. A néhánytól az egyciklusú impulzusokig a vivőhullám és a burkoló egymáshoz viszonyított pozíciója, illetve annak változásai a fény-anyag kölcsönhatás kimenetelét alapvetően meghatározzák. Emiatt a lézerimpulzusok mind amplitúdóban, mind pedig fázisban kontrollált előállítása kiemelt fontosságú. Egy mérés során a mintára vagy másodlagos forrásba érkező impulzusok paramétereinek stabilitása kritikus lehet. Különösen igaz ez az állítás a fázis impulzusról impulzusra, valamint a hosszabb időskálán bekövetkező változásaira.

A lézererősítők müködésének egyik fö problémája az erősítő közegben fellépő hőterhelés. Szilárdtest lézerek esetén ugyanis az aktív közeg gerjesztése fénnyel történik, amely intenzitás spektrumának nagy része a lézerközeg abszorpciós sávjába esik. Az erősítő közegben tárolt energiát indukált emisszió révén kicsatoljuk, azonban az erősítés mellett energiaveszteség is jelentkezik, amely hő formájában terheli a közeget. Az említett probléma az elnyelt átlagteljesítménnyel skálázódik.

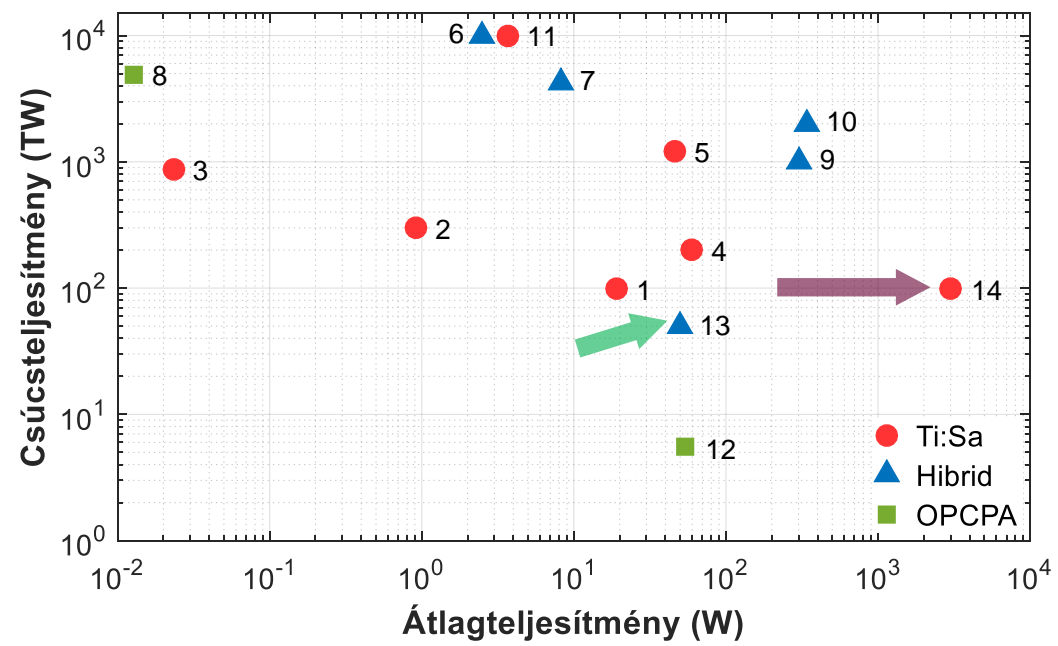

I.1. ábra Néhány lézerrendszer csúcs- és átlagteljesítményének összehasonlítása. Pirossal jelöltem a Ti:Sa alapú rendszereket: 1 [4], 2 (HERCULES) [5], 3 (J-KAREN) [6], 4 (VEGA 2) [7], 5 (BELLA PW) [8], 11 (ELI-NP HPLS) [9], 14 (k-BELLA projekt, tervezés alatt) [10]. Kékkel jelöltem a hibrid, optikai parametrikus (OPCPA) és Ti:Sa erősítőkön alapú rendszereket: 6 (APOLLON) [11], 7 [12], 9 (ELI-Beamlines HAPLS) [13], 10 (ELI-ALPS HF-2PW) [14], 13 (ELI-ALPS HF-100) [14]. Végül két optikai parametrikus erősítésen (OPCPA) alapú rendszert is felvázoltam, ezeket zölddel jelöltem: 8 [15], és 12 (ELI-ALPS SYLOS 1) [16].

A lézererősítőkben lévő aktív közegek több geometriában is előfordulhatnak, jellemzően hengeres rúd alakúak. Ugyanakkor számos olyan konfigurációt is találhatunk, amelyekben téglatest, korong, vagy akár optikai szál formájában jelenik meg az erősítő közeg. Az aktív közeg geometriájának nem csupán az erősítő elrendezés és a pumpálás szempontjából van jelentősége, hanem annak hűtését is alapvetően meghatározza. Jellemzően ugyanis a pumpanyaláb révén intenzív hőterhelés éri az aktív közeget, amely 
effektív hütést igényel emiatt. Ennek eredményeképpen az adott erősítő rendszer által előállított impulzusenergia, ismétlési frekvencia, és így átlagteljesítményének felskálázását az erősítő egységek hütése erősen limitálja. A legtöbb esetben szobahőmérsékleten, jellemzően vízhűtéses módszerrel hűtik a lézererősítők aktív közegét. Nagy átlagteljesítményű nyalábok előállítása során azonban szükséges kriogenikus hőmérsékletre lehüteni a lézerközeget, amely révén annak fizikai, illetve spektroszkópiai tulajdonságai előnyösen változnak meg, és így kedvezőbb lézermüködés érhető el. Néhány fontosabb nagy csúcsteljesítményü lézerrendszert az I.1. ábra szemléltet. A legmodernebb, jelenleg telepítésre kerülő lézerek közül az I.1. ábrán 9-es és 10-es számmal jelölt rendszerek kiemelkedőek a csúcs- és az átlagteljesítmény tekintetében is. A tervezés alatt álló, 13-as és 14-es számmal jelölt lézerek megvalósításához további kutatás-fejlesztés szükséges (I.1. ábra, zöld és lila nyilak).

Értekezésem során a Ti:Sa alapú lézererősítés során fellépő fázisinstabilitások feltérképezésén, valamint a nagyenergiájú erősítők csúcs- és átlagteljesítményének felskálázási lehetőségeinek vizsgálatára fogok fókuszálni. A munkám során keletkezett új tudományos eredmények megértéséhez szükséges alapvető fogalmakat, mérési módszereket, illetve berendezéseket a dolgozat első szakaszában fogom ismertetni. Ez a rövid tudományterületi összefoglaló tartalmazza az ultrarövid impulzusok terjedésének, illetve erősítésének matematikai leírását. Ismertetni fogom a nagyintenzitású erősítő rendszerek felépítését és müködését. Röviden bemutatom továbbá a lézerek átlagteljesítményének növelésére nagy sikerekkel alkalmazott koronglézer architektúra jellemzöit. Végül pedig be fogom mutatni az impulzusok vivőhulláma és burkolója közötti fáziskülönbség jellemzőit, és a stabilitásával kapcsolatos problémákat. Az elméleti alapok bemutatását követően rátérek tudományos munkám motivációira, valamint néhány pontban összegezni fogom a célkitüzéseimet. A dolgozat hátralévő részében a kutatásaim során keletkezett új tudományos eredményeimet fogom részletezni. Ezek az eredmények magukban foglalják a víz- és kriogenikus hütésü multipasszos erősítők spektrális- és vivőburkoló fázisának stabilitásával kapcsolatos mérések eredményeit. Továbbá, tárgyalni fogom a nagyenergiájú Ti:Sa erősítők átlagteljesítményének növelését lehetővé tevő új típusú, koronglézer geometriájú erősítő elrendezés vizsgálata során született eredményeket. Végül bemutatom a koronglézer architektúrán alapuló nagyenergiás erősítők felskálázásával kapcsolatos szimulációim eredményeit.

A disszertációmban ismertetett kísérleti munkát a Szegedi Tudományegyetem Optikai és Kvantumelektronikai Tanszékének TeWaTi Femtoszekundumos Lézer Laboratóriumában, valamint a Berlinben található Max-Born-Institut für Nichtlineare Optik und Kurzzeitspektroskopie im Forschungsverbund Berlin e. V. intézetben végeztem el. A nagyenergiájú korongerösítőkkel kapcsolatos numerikus modellezést az ELI-ALPS Kutatóközpont (ELI-HU Nonprofit Kft.) számítástechnikai infrastruktúrájának felhasználásával valósítottam meg. 


\section{Tudományos előzmények}

\section{II.1. Ultrarövid lézerimpulzusok és terjedésük hatásai}

Az ultrarövid impulzusok matematikai leírása a tér- és időfüggő elektromos tér segítségével oldható meg. A mágneses térkomponenst jellemzően nem vesszük figyelembe az elektromágneses impulzusok tárgyalása folyamán, mivel annak a relativisztikus fény-anyag kölcsönhatások során van szignifikáns hatása. Konvencionális módszer a femtoszekundumos impulzusok tárgyalását félklasszikus közelítésben elvégezni, amelyet én is követni fogok. Ebben az esetben a hullámcsomagok terjedését, valamint anyaggal való kölcsönhatását a Maxwell-egyenletek írják le, amelyben az anyag elektromágneses hullámokra adott válaszát a makroszkopikus polarizációval adjuk meg. Praktikus tulajdonsága ennek a leírásmódnak, hogy az impulzust mérhető mennyiségek segítségével adjuk meg. A szokást megtartva, az elektromos térerősséget komplex reprezentáció segítségével fogom leírni, amely különösen hatékony módja az elektromágneses hullámcsomagok terjedési problémáinak.

\section{II.1.1. Komplex elektromos térerősség és a spektrális fázis}

Matematikailag egy ultrarövid impulzus (sorozat) különbözö frekvenciájú monokromatikus hullámok összegeként írható le. Ahhoz azonban, hogy a hullámok összege valóban az időben jól lokalizált térerősség amplitúdó csúcsokat adjon, a különböző, de közeli frekvenciájú hullámok fázisának egymáshoz képest rögzített állapotban kell lennie. Az ilyen hullámcsomagok időbeli karakterisztikájának meghatározásához tekintsünk el az elektromos térerősség térbeli és polarizációs függésétől, azaz legyen

$$
\mathbf{E}(x, y, z, t)=E(t)
$$

Bár az elektromos térerősséghez kapcsolt, mérhető mennyiségek valósak, érdemes áttérni a komplex térerősséget tartalmazó tárgyalásmódra $[17,18]$. Az idő- és a frekvenciatartomány közötti kapcsolatot a komplex Fourier-transzformáció teremti meg, amelyet felhasználva a valós $E(t)$ tér és az annak megfelelő $\tilde{E}(\omega)$ térerősség spektrumra érvényes az

$$
\tilde{E}(\omega)=\mathcal{F}\{E(t)\}=\int_{-\infty}^{\infty} E(t) e^{-i \omega t} d t=|\tilde{E}(\omega)| e^{i \varphi(\omega)}
$$

összefüggés, ahol $\omega$ a körfrekvenciát, $|\tilde{E}(\omega)|$ a spektrális amplitúdót, valamint $\varphi(\omega)$ a spektrális fázist jelöli. A spektrális fázis fogalmára, valamint fontosságára később részletesen kitérek. Az $E(t)$ időfüggő elektromos térerősség az $\tilde{E}(\omega)$ spektrum ismeretében az inverz Fourier-transzformációval kapható meg, mely szerint

$$
E(t)=\mathcal{F}^{-1}\{\tilde{E}(\omega)\}=\frac{1}{2 \pi} \int_{-\infty}^{\infty} \tilde{E}(\omega) e^{i \omega t} d \omega
$$

Mivel $E(t)$ valós függvény, érvényes az $\tilde{E}(\omega)=\widetilde{E}^{*}(-\omega)$ reláció, amelyből azonban jól látható, hogy negatív frekvenciák esetén is nem zéró elektromos térerősség amplitúdót kaphatunk. Ez ugyan elméleti szempontból nem tiltott, gyakorlati szempontból azonban érdemes kerülni a számolások egyszerübb kivitelezésének érdekében. Éppen ezért érdemes bevezetni az 


$$
\tilde{E}^{+}(\omega)=|\tilde{E}(\omega)| e^{i \varphi(\omega)}=\left\{\begin{array}{lll}
\tilde{E}(\omega) & \text { ha } & \omega \geq 0 \\
0 & \text { ha } & \omega<0
\end{array}\right.
$$

konvenciót, amely alapján a negatív frekvenciatartományban nincs zérótól különböző amplitúdójú térerősség. A gyakorlatban nem csak a frekvenciatartományban, hanem időben is érdemes komplex reprezentációjú elektromos térdefiníciót használni. Ekkor a csak pozitív frekvenciákat tartalmazó, időfüggő komplex elektromos térerősség az

$$
\tilde{E}^{+}(t)=\frac{1}{2 \pi} \int_{-\infty}^{\infty} \tilde{E}^{+}(\omega) e^{i \omega t} d \omega
$$

egyenlet segítségével definiálható, míg a pozitív frekvenciákhoz tartozó komplex térerősség spektrum pedig az

$$
\tilde{E}^{+}(\omega)=\int_{-\infty}^{\infty} \tilde{E}^{+}(t) e^{-i \omega t} d t
$$

összefüggéssel kapható, vagyis $\tilde{E}^{+}(t)$ és $\tilde{E}^{+}(\omega)$ a komplex Fourier-transzformáción keresztül feleltethetőek meg egymásnak a (II.2) és (II.3) egyenletekhez hasonlóan. A pozitív frekvenciákhoz tartozó térerősséghez hasonlóan a negatív frekvenciákhoz rendelt $\widetilde{E}^{-}(t)$ és $\widetilde{E}^{-}(\omega)$ mennyiségek is definiálhatóak.

Az $\widetilde{E}^{+}(t)$ térerősséget a (II.2) kifejezéshez hasonlóan egy amplitúdó és egy fázistag szorzataként felírni, amely az

$$
\tilde{E}^{+}(t)=\frac{1}{2} \varepsilon(t) e^{i \Gamma(t)}
$$

kifejezéssel tehető meg. Egy laboratóriumban is megtalálható valós impulzusforrás esetén az elektromos térerősség spektrális amplitúdója csak egy adott $\omega_{0}$ frekvencia körül felvett $\Delta \omega$ szélességü frekvenciatartományon lesz nullától mérhetően különbözö. Az $\omega_{0}$ és a $\Delta \omega$ értékét az adott impulzusforrásban található lézerközeg emissziós spektruma határozza meg. Az $\omega_{0}$ értéket szokás a vivőhullám frekvenciájának nevezni, amelyet felhasználva a következő kifejezést írhatjuk fel a komplex térerősségre:

$$
\tilde{E}^{+}(t)=\frac{1}{2} \varepsilon(t) e^{i \varphi_{C E}} e^{i \Phi(t)} e^{i \omega_{0} t}=\frac{1}{2} \tilde{\varepsilon}(t) e^{i \omega_{0} t}
$$

ahol $\Phi(t)$ az időfüggő fázis, míg $\varepsilon(t)$ a valós térerősség burkoló, míg $\tilde{\varepsilon}(t)$ pedig a komplex térerősség burkoló. A konstans fázistagban található $\varphi_{C E}$ mennyiséget szokás vivő-burkoló fázisnak (carrierenvelope phase, $\boldsymbol{C E P}$ ) nevezni, amely dolgozatom egy részének központi témája, a II.1.3. szakaszban fogok kitérni részletesen. A vivőhullám és a burkoló fogalmának bevezetése jelentősen egyszerüsíti az ultrarövid impulzusok terjedésének és anyaggal való kölcsönhatásának leírását, azonban figyelmesen kell eljárnunk ezzel kapcsolatban. Ha az impulzus frekvenciaspektrumának szélessége jóval kisebb, mint a vivőhullám frekvenciája, azaz

$$
\frac{\Delta \omega}{\omega_{0}}<<1
$$


akkor ez a definíció jól érvényesül. Ez azt jelenti, hogy $\varepsilon(t)$ és $\Phi(t)$ változása az impulzus egy optikai ciklusán belül kicsiny, vagyis érvényes az

$$
\left|\frac{d \tilde{\varepsilon}(t)}{d t}\right| \ll \omega_{0}|\tilde{\mathcal{E}}(t)|
$$

reláció. A (II.9) és (II.10) összefüggések által rögzített feltételek által definiált approximációt lassan változó burkoló közelitésnek (slowly varying envelope approximation, SVEA) nevezzük. A jelenleg korszerü impulzusforrások már alkalmasak egyciklusos impulzusok előállítására, amely megköveteli az imént bevezetett közelítések felülbírálását az impulzusterjedés és a különböző anyaggal létrehozott kölcsönhatások pontos tárgyalására. A vivőhullám frekvenciáját úgy szokás megválasztani, hogy a spektrális amplitúdó $\omega_{0}$-ra centrált legyen. Ez a módszer bár gyakorlati szempontból rendkívül elönyös az egyszerüsége miatt, azonban valós lézerrendszerek spektruma gyakran strukturált, ami az előbbi megválasztást nem teszi lehetővé. Éppen ezért érdemes egy pontosabb definícióval élni, amely az

$$
\omega_{0} \equiv\langle\omega\rangle=\frac{\int_{-\infty}^{\infty} \omega\left|\tilde{E}^{+}(\omega)\right|^{2} d \omega}{\int_{-\infty}^{\infty}\left|\tilde{E}^{+}(\omega)\right|^{2} d \omega}
$$

kifejezéssel adható meg. A (II.11) összefüggés az intenzitás spektrális eloszlásának súlyozott átlaga, és érdemes megemlíteni, hogy ez a módszer az időképben is konzisztensen használható.

Egy ultrarövid impulzus (II.2) összefüggésben bevezetett spektrális fázisának jellemzéséhez szokás azt a vivőfrekvencia körül Taylor-sorba fejteni a következő módon:

$$
\varphi(\omega)=\varphi_{0}+\varphi_{0}^{\prime} \cdot\left(\omega-\omega_{0}\right)+\frac{1}{2 !} \varphi_{0}^{\prime \prime} \cdot\left(\omega-\omega_{0}\right)^{2}+\frac{1}{3 !} \varphi_{0}^{\prime \prime \prime} \cdot\left(\omega-\omega_{0}\right)^{3}+\ldots,
$$

ahol

$$
\varphi_{0}^{(m)}=\left.\frac{d^{m} \varphi(\omega)}{d \omega^{m}}\right|_{\omega=\omega_{0}}
$$

a különböző rendủ fázisderiváltakat jelöli. Ezek a mennyiségek igen szemléletes fizikai jelentéssel bírnak, ezért külön elnevezést kaptak a szakirodalomban a következőek szerint: csoportkésleltetésnek (group delay, $\boldsymbol{G D}$ ) nevezzük a

$$
\left.G D \equiv \frac{d \varphi(\omega)}{d \omega}\right|_{\omega=\omega_{0}}=\varphi_{0}^{\prime}
$$

mennyiséget, míg csoportkésleltetés-diszperziónak (group delay dispersion, GDD) a

$$
\left.G D D \equiv \frac{d^{2} \varphi(\omega)}{d \omega^{2}}\right|_{\omega=\omega_{0}}=\varphi_{0}^{\prime \prime}
$$

értéket, továbbá jelentősége miatt szokás definiálni a harmadrendü diszperziót (third order dispersion, TOD) a

$$
\left.T O D \equiv \frac{d^{3} \varphi(\omega)}{d \omega^{3}}\right|_{\omega=\omega_{0}}=\varphi_{0}^{\prime \prime \prime}
$$


kifejezéssel. Ezeken túl a gyakorlati alkalmazások szempontjából meg szokás említeni a negyed- (fourth order dispersion, FOD) és ötödrendü diszperziót (fifth order dispersion, QOD) is, amelyek a (II.13) formula alapján definiálhatóak. A fázisderiváltak segítségével tetszőleges impulzus spektrális fázisa karakterizálható adott vivőfrekvencián. Érdemes megemlíteni, hogy a femtoszekundumos impulzusok diagnosztikája során ezen mennyiségeket határozzuk meg.

\section{II.1.2. Impulzusok terjedése lineáris optikai közegben}

Az ultrarövid impulzusok lineárisan diszperzív optikai közegen való áthaladása során azok időbeli alakja megváltozik, amely az egyes frekvenciakomponensek közötti fázisviszony átrendeződik az adott közeg törésmutatójának frekvenciafüggése következtében. Érdemes megvizsgálni, miként hat egy impulzus időbeli struktúrájára a terjedés során akkumulált fázisváltozás, hiszen azok bármely lézerrendszer esetén számos optikai komponensen haladnak át.

Vizsgálatunkhoz tekintsünk az egyszerüség kedvéért egy időben Gauss-eloszlású térerősség burkolóval leírható impulzust. A korábbi tárgyalásmódhoz képest annyi változtatást végezzünk el, hogy egydimenziós térbeli terjedést is adjunk hozzá a számolásunkhoz. Ekkor legyen a z irányban terjedő impulzus intenzitásburkolójának a kiindulási pontban mért $\tau_{0}$ félértékszélessége, amely a maximális intenzitás felénél mért időbeli szélesség (full width at half maximum, FWHM). Továbbá, legyen a térerősség maximális amplitúdója $E_{0}$, a vivőhullám frekvenciája $\omega_{0}$, illetve rendelkezzen az impulzus a $t=0$ helyen $\phi_{0}$ kezdőfázissal. Az impulzus valós időfüggő térerőssége ekkor az

$$
E(z=0, t)=E_{0} \exp \left[-2 \ln (2) \frac{t^{2}}{\tau_{0}^{2}}\right] \cdot \exp \left[i \omega_{0} t+i \phi_{0}\right]
$$

alakban írható fel. Elvégezve a (II.17) összefüggésen a komplex Fourier-transzformációt, a megfelelő

$$
\tilde{E}(\omega)=\frac{E_{0} \tau_{0}}{\sqrt{\ln (2)}} \exp \left(i \phi_{0}\right) \cdot \exp \left[-\frac{\tau_{0}^{2}}{8 \ln (2)}\left(\omega-\omega_{0}\right)^{2}\right] .
$$

komplex térerősség spektrumot kapjuk. Matematikai okokból a Gauss-burkolójú időalakhoz Gausseloszlású spektrum adódik, amely $\omega_{0}$ frekvenciára centrált. Észrevehetjük, hogy a $\Delta \omega$ spektrális sávszélesség és a $\tau_{0}$ időbeli hossz között a

$$
\Delta \omega \cdot \tau_{0}=4 \ln (2)
$$

összefüggés áll fent. Megjegyzem, hogy a (II.19) összefüggés Gauss-eloszlású impulzusalakra vonatkozik, azonban más függvénnyel leírt impulzusalakokra is hasonló kifejezés nyerhető [17]. A (II.17) és (II.18) kifejezésekkel leírt impulzus esetén feltettük, hogy minden spektrális komponens azonos $\phi_{0}$ fázissal rendelkezik, így az impulzus spektrális fázisa konstans minden frekvencián. Ezért az impulzus időbeli félértékszélessége ebben az esetben minimális kell, hogy legyen. Ezt a Fouriertranszformáció által egy adott $\Delta \omega$ spektrális sávszélesség által megengedett legrövidebb $\tau_{0}$ értéket transzformáció-limitált impulzusidőnek nevezzük. Más impulzusalakokra vonatkozó, transzformáció limithez tartozó sávszélesség-idő produktumok értékével kapcsolatban például a [17] forrásmunkában tájékozódhatunk.

Tekintsünk egy $n(\omega)$ törésmutatóval rendelkezö lineáris optikai közeget, amelyen való áthaladás során a (II.18) kifejezéssel leírt Gauss-alakú spektrum változatlan marad. Ugyanakkor, az közegben $z$ távolságú terjedés után az elektromos térerősség időbeli alakját az 


$$
\begin{aligned}
& E(z, t)=\frac{1}{2 \pi} \int_{-\infty}^{\infty} \tilde{E}(\omega) \exp [i(\omega t-k z)] d \omega= \\
& =\frac{1}{2 \pi} \int_{-\infty}^{\infty} \tilde{E}(\omega) \exp [i \omega(t-n(\omega) z / c)] d \omega
\end{aligned}
$$

összefüggéssel kiszámolva látható, hogy az impulzus frekvenciakomponenseit egy

$$
\varphi(\omega)=\omega \cdot n(\omega) \cdot \frac{z}{c}
$$

alakú spektrális fázisváltozás éri. A (II.21) kifejezésben definiált spektrális fázistolást a (II.12) összefüggéssel megadott Taylor-sorba fejtve megkaphatóak a közegre adott $\omega_{0}$ vivőfrekvencián értelmezett fázisderiváltak értékei. A spektrális fázis Taylor-sorából második rendig behelyettesítve a (II.20) egyenletbe az

$$
E(z, t)=\frac{1}{2 \pi} \int_{-\infty}^{\infty} \tilde{E}(\omega) \exp \left[i \omega t-i\left(\varphi_{0}+G D \cdot\left(\omega-\omega_{0}\right)+\frac{1}{2} G D D\left(\omega-\omega_{0}\right)^{2}\right)\right] d \omega
$$

összefüggést nyerjük. Ebbe behelyettesítve a (II.18) egyenlettel definiált térerősség spektrumot, és elvégezve az integrálást az

$$
E(z, t)=E_{0} \frac{\tau_{0}}{\sqrt[4]{\tau_{0}^{2}+(4 \ln (2) \cdot G D D)^{2}}} \exp \left[-2 \ln (2) \frac{(t-G D)^{2}}{\tau^{2}}\right] \exp [i \Phi(z, t)]
$$

időfüggő elektromos térerősséget kapjuk. Az elektromos térerősséghez hasonlóan az időfüggő fázis is kiszámítható, amely a

$$
\Phi(z, t)=\Phi_{0}-\varphi_{0}+\omega_{0} t+\frac{(t-G D)^{2}}{2 \cdot G D D+\frac{\tau_{0}^{4}}{8(\ln (2))^{2} \cdot G D D}}+\frac{1}{2} \arctan \left(\frac{2 \ln (2) \cdot G D D}{\tau_{0}^{2}}\right)
$$

alakot fogja felvenni [17,19-21]. A (II.23) kifejezés alapján a másodrendig figyelembe vett diszperzióval rendelkező impulzus időbeli hosszára a

$$
\tau=\tau_{0} \sqrt{1+\left(\frac{G D D \cdot 4 \ln (2)}{\tau_{0}^{2}}\right)^{2}}
$$

formula adódik. A (II.23) összefüggésből tükröződik, hogy a csoportkésleltetés, azaz a GD az impulzus időbeli eltolását adja meg, és a (II.25) kifejezésből jól láthatóan az impulzus időbeli alakjára nincs hatással. A GD fizikailag azt jelenti, hogy az impulzus burkolója ennyi idővel késik, mivel az nem a frekvenciakomponensek

$$
v_{p} \equiv \frac{\omega}{k}=\frac{n(\omega)}{c}
$$

fázissebességével, hanem a csoportsebességgel, azaz a 


$$
\left.v_{g} \equiv \frac{d \omega}{d k}\right|_{k=k_{0}}=\frac{c}{n\left(\omega_{0}\right)+\left.\omega_{0} \frac{d n(\omega)}{d \omega}\right|_{\omega=\omega_{0}}}=\frac{z}{G D}
$$

kifejezéssel definiált sebességgel terjed, ahol $k=2 \pi / \lambda$ az adott hullámhosszhoz tartozó hullámszám, valamint $c$ a vákuumbeli fénysebesség.

Belátható, hogy a másodiknál magasabb rendủ fázisderiváltak szintén az impulzusok időbeli alakjának torzulását eredményezik. Erről numerikus szimulációk elvégzésével egyszerüen meggyőződhetünk, amelyek eredményeként az egyes fázisderiváltak hatásait az ötödik rendig összefoglalóan a II.1. ábra szemlélteti.
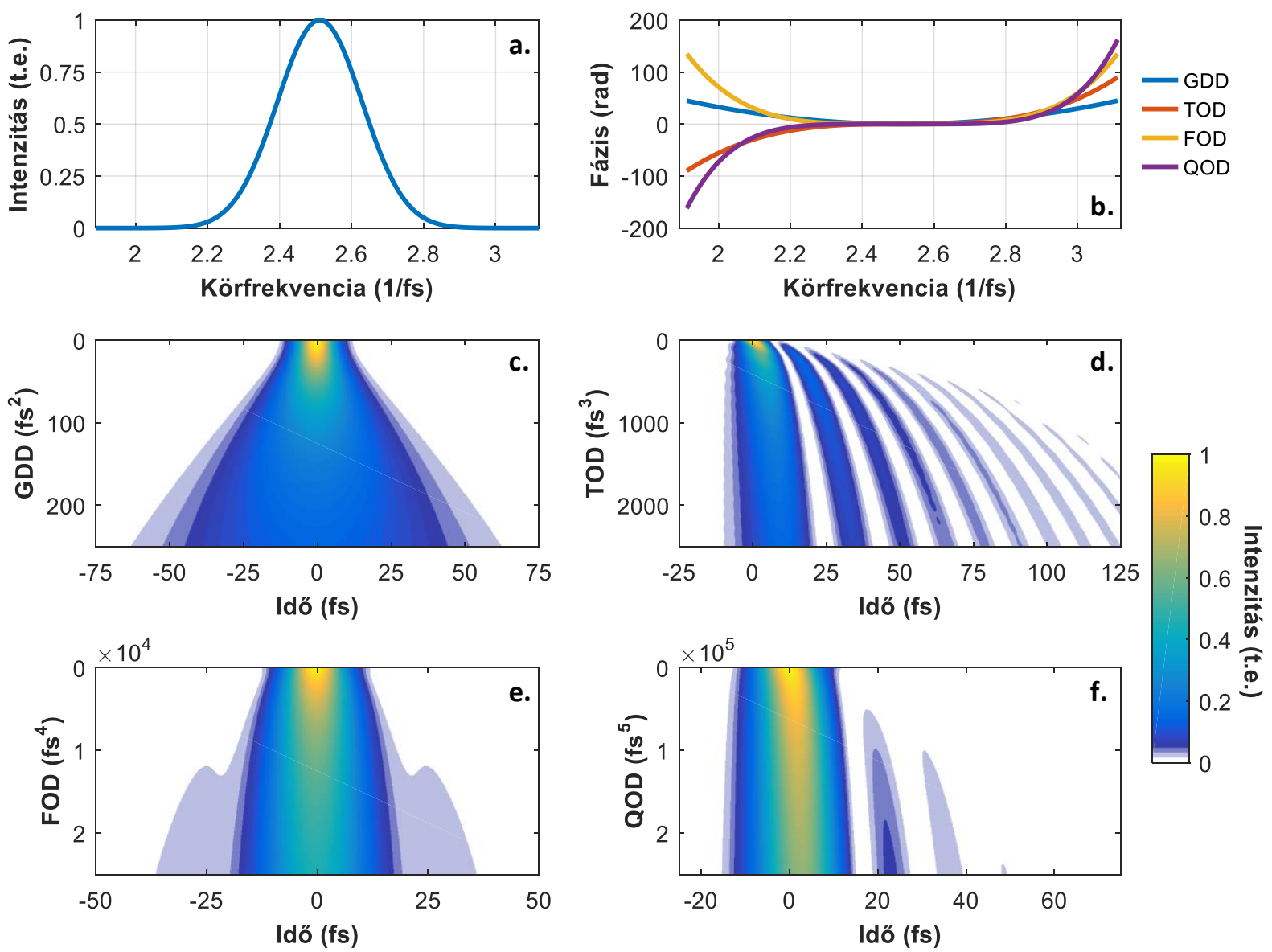

II.1. ábra Szimulált intenzitás spektrum egy 10 fs időbeli hosszúságú transzformáció-limitált impulzus esetén, ahol $\omega_{0}$ központi frekvencia $750 \mathrm{~nm}$ hullámhossznak felel meg (a). Spektrális fázis $250 \mathrm{fs}^{2} \mathrm{GDD}, 2500 \mathrm{fs}^{3}$ TOD, $25000 \mathrm{fs}^{4} \mathrm{FOD}$, valamint $250000 \mathrm{fs}^{5}$ QOD esetén (b). Intenzitás spektrumból az adott rendű fázissal számolt időbeli intenzitásalak változása másodrendủ (c), harmadrendủ (d), negyedrendű (e), illetve ötödrendű diszperzió esetén (f). A színkódolás az impulzus normált intenzitásértékeit adja meg.

A II.1. ábrán egy szimulált 10 fs transzformáció-limitált időbeli hosszúsággal rendelkező impulzus Gauss-típusú intenzitásspektruma (II.1. ábra, (a) rész) figyelhető meg, amely esetén a központi frekvencia $750 \mathrm{~nm}$ hullámhossznak felel meg. Amennyiben a spektrális fázis csak a különbözö magasabb rendủ tagokból áll, a II.1. ábra (b) részén látható fázisgörbéket kapjuk. A II.1. ábra (b) részén ábrázolt spektrális fázisokat az impulzus időbeli alakjának kiszámítása során behelyettesítve megkapható az egyes fázistagok időbeli alakra gyakorolt hatása egymástól függetlenül. Tisztán másodrendủ diszperzió esetén a II.1. ábra (c) részén látható GDD-idő térképet kapjuk, amelyről 
leolvasható, hogy az eredetileg 10 fs hosszú impulzus szimmetrikusan kiszélesedik a GDD növelésével, amely összhangban van a (II.25) kifejezéssel. Az impulzus időbeli megnyúlása a csúcsintenzitás jelentős csökkenésével jár együtt. Áttérve a TOD hatására, a II.1. ábra (d) részén vázolt TOD-idő térkép kapható, amelyen az impulzus aszimmetrikus kiszélesedését, valamint a TOD növelésével egyre több mellékimpulzus megjelenését figyelhetjük meg. A mellékcsúcsok jelentősen rontják az impulzus kontrasztját, hiszen egyre kevesebb energia koncentrálódik a föcsúcsban. A II.1. ábra (e) részén ábrázolt FOD-idő térképről szintén szimmetrikus kiszélesedés, valamint az impulzus mindkét oldalán ún. vállak megjelenését láthatjuk, amely ismételten az időbeli kontraszt leromlását eredményezi. Végül pedig a QOD-idő térképet tekintve a II.1 ábra (f) részén, a TOD hatásához hasonló struktúrát figyelhetünk meg, amely a magasrendű fázistagok időbeli torzító hatásának általános viselkedésére ad következtetést: a páros rendek szimmetrikus kiszélesedést, míg a páratlan rendek pedig aszimmetrikus kiszélesedést és mellékimpulzusok megjelenését eredményezik. Az impulzus időbeli hosszának változására a II.2. ábra alapján belátható, hogy a GDD hatása a legjelentősebb.
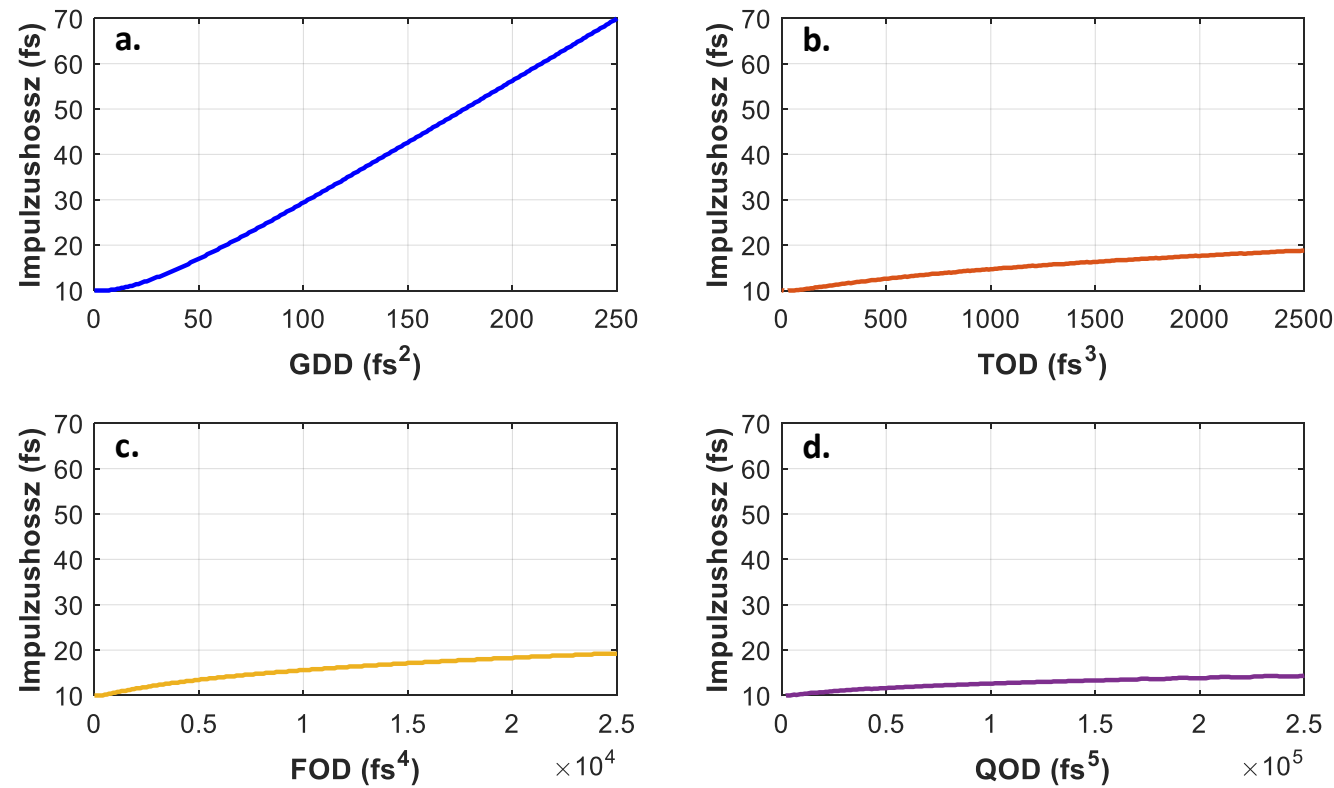

II.2. ábra Impulzushossz változása a GDD (a), TOD (b), FOD (c), illetve a QOD (d) különböző értékei esetén a II.1. ábra (a) részén látható 10 fs időbeli hosszúságú impulzusok esetén.

Érdemes azonban megemlíteni, hogy bár a GDD-nél magasabb rendek az impulzus időbeli félértékszélességére jóval kisebb hatással vannak, azonban ezek torzító hatása mégis jelentős, hiszen egyre kevesebb energia koncentrálódik az impulzus főcsúcsában. Ennek eredményeként, az impulzus csúcsintenzitása és kontrasztja jelentősen lecsökken, amely a felhasználás szempontjából rendkívül hátrányos. Amennyiben az impulzus BK7 vagy ömlesztett kvarc üvegen halad keresztül, a fázisderiváltak közül a GDD hatása jelentős az időbeli alakra nézve. Magasabb diszperziójú közegek, például zafír, vagy nehéz flint üvegek esetén ugyanakkor már a TOD is jelentős mértékben lép fel. Érdemes megemlíteni, hogy a TOD-nál magasabb rendek általában a II.1. ábrán vizualizált értékekhez képest jóval kisebb szinten lépnek fel, így azokat a gyakorlatban általában elhanyagolják. Az optikai közegek diszperzióját szokás az ún. fajlagos fázisderiváltakkal, vagyis az egységnyi hosszúságú közegbeli terjedés esetén fellépő diszperzió értékével jellemezni. Ezeket az értékeket az SGD (specific group delay), SGDD (specific group delay dispersion), STOD (specific third order dispersion), stb. elnevezésekkel adják meg. 
Ha az impulzus időbeli alakja strukturált, azaz a föcsúcsban található energiához képest további mellékcsúcsokban is koncentrálódik nem elhanyagolható mennyiségü energia, az időbeli félértékszélesség definíció nem ad pontos jellemzést. Ilyenkor érdemes bevezetni a $\Delta \tau$ négyzetes középérték (root mean square, $\boldsymbol{R M S}$ ) időbeli hossz fogalmát, amely elöáll a

$$
\Delta \tau^{2}=\left\langle\left(t-\langle t\rangle^{2}\right)\right\rangle=\int_{-\infty}^{\infty}(t-\langle t\rangle)^{2} I(t) d t=\int_{-\infty}^{\infty}|(t-\langle t\rangle) E(t)|^{2} d t
$$

formában, ahol $\langle t\rangle$ az időbeli intenzitás profil tömegközéppontja, $I(t)$ pedig az impulzus időbeli intenzitásprofilja [22]. Az RMS időbeli hossz figyelembe veszi a strukturált spektrális intenzitással, illetve a magas rendű tagokat tartalmazó spektrális fázissal rendelkező impulzusok időbeli alakjának torzulásait.

\section{II.1.3. Vivő-burkoló fázis}

A II.1.1. alfejezetben leírt SVEA közelítés közelítőleg három oszcillációs ciklus alatti impulzusok esetén érvényességét veszti. Tekintettel arra, hogy már az ezredforduló első évei óta rutinszerủ feladat a néhány ciklusos lézerimpulzusok elóállítása [23-29], a vivőhullám oszcillációjának burkolóhoz képesti fluktuációját figyelembe kell vennünk. Ekkor ugyanis a vivőhullám és a burkoló közötti fáziskülönbség, azaz a vivő-burkoló fázis hatással lesz az impulzus terjedésére és a közeggel való kölcsönhatás kimenetelére. Ezt a fázis értéket néha szokás abszolút fázisnak is nevezni. Két irányzat szerint szokás a vivő-burkoló fázist definiálni: az oszcillátorok esetén a vivő-burkoló offszet frekvencia meghatározást alkalmazzák, jellemzően a frekvencia metrológia témakörében; addig az izolált és erősített impulzusok esetén a vivő-burkoló fázist szokás használni.
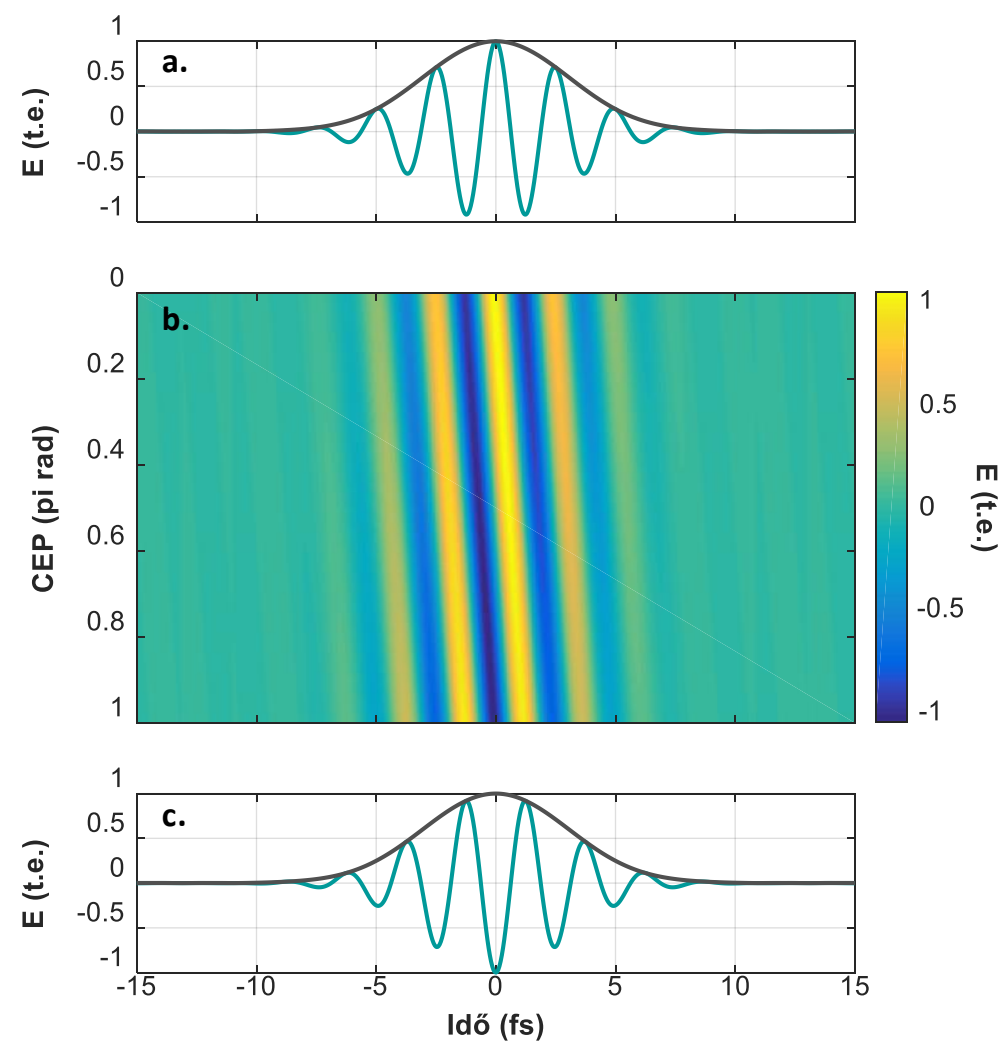

II.3. ábra Vivőhullám és a burkoló egy 5 fs félértékszélességű intenzitásburkolóval rendelkező impulzus esetén. A burkoló maximuma és a vivőhullám legközelebbi maximuma közötti időbeli különbség arányos a CEP értékével. 
Jelen munkában az utóbbi definíciót használtam fel, amely szerint

$$
\varphi_{C E} \equiv \Phi\left(z^{*}, t^{*}\right)
$$

ahol az $E\left(z^{*}, t^{*}\right)=\max (|E(z, t)|)$, a (II.23) és (II.24) kifejezések érvényesek. Az időbeli reprezentációt felhasználva tekintsünk egy izolált néhány ciklusos impulzust, amely esetén a $\varphi_{C E}$ vivő-burkoló fázis szemléletes jelentését a II.3. ábráról olvashatjuk le. Az impulzus burkolójának csúcsértéke és a vivőhullám térerősségének az előbbihez legközelebbi maximuma közötti időkülönbségre vonatkozóan felírható a

$$
\varphi_{C E}=\Delta t \cdot \omega_{0}
$$

összefüggés, amely megadja a CEP időbeli reprezentációjában vett definícióját.

Térjünk most át a frekvenciatérbeli reprezentációra és tegyük fel, hogy az adott impulzus egy $z$ vastagságú lineárisan diszperzív közegen halad keresztül. Ekkor a (II.21) kifejezéssel definiált fáziseltolódás jön létre az egyes frekvenciakomponensek esetén. Továbbá, mivel a burkoló a fázissebességgel, addig a vivőhullám a csoportsebességgel terjed, a CEP értéke megváltozik a közegben való terjedés során. Felhasználva a fázissebesség és a csoportsebesség (II.26) és (II.27) meghatározásait, a CEP változására, vagy csúszására a

$$
\Delta \varphi_{C E}=\omega_{0} z\left(\frac{1}{v_{g}}-\frac{1}{v_{p}}\right)=\left.z \frac{\omega_{0}^{2}}{c} \frac{d n(\omega)}{d \omega}\right|_{\omega=\omega_{0}}
$$

kifejezés nyerhető [30]. Érdemes megemlíteni, hogy mivel a teljes $2 \pi$ fázis csúszások nem eredményeznek változást az impulzus vivőhullámának burkolóhoz viszonyított helyzetében, a CEP csúszásának megadásánál ezeket szokás eliminálni a

$$
\Delta \varphi_{C E, m}=\Delta \varphi_{C E} \bmod 2 \pi
$$

kifejezés segítségével. A spektrális fázis Taylor-sorában található nulladik és első rendủ deriváltjait felhasználva a CEP csúszására a

$$
\Delta \varphi_{C E}=\varphi\left(\omega_{0}\right)-\left.\frac{d \varphi(\omega)}{d \omega}\right|_{\omega=\omega_{0}} \cdot \omega_{0}=\varphi_{0}-G D \cdot \omega_{0}
$$

kifejezést kaphatjuk. A fázisstabilitásra vonatkozó méréseim kiértékelése során mindvégig a (II.33) közelítés segítségével határoztam meg a CEP csúszásának és zajának értékét, így dolgozatomban is ezt a kifejezést fogom használni.

Izolált impulzus helyett egy impulzussorozatot tekintve a frekvencia spektrum finomszerkezetében is megfigyelhető $\Delta \varphi_{C E}$ hatása. Tekintsünk ehhez egy femtoszekundumos lézeroszcillátort, amelyben az impulzus minden körbejárás során $\Delta \varphi_{C E}$ fázistolást szenved, amelyre vonatkozóan érvényes az

$$
f_{C E O}=\frac{\Delta \varphi_{C E}}{2 \pi T_{r}}=\frac{\Delta \varphi_{C E}}{2 \pi} f_{\text {rep }}
$$

összefüggés, ahol $f_{\text {rep }}=c / 2 L$ a lézer ismétlési frekvenciája, valamint $L$ a rezonátor hossza. Az $f_{C E O}$ mennyiséget nevezzük vivö-burkoló offszet frekvenciának vagy frekvenciafésủ offszetnek. Ha az időben ekvidisztáns, $1 / f_{\text {rep }}$ távolságra lévő, és $\Delta \varphi_{C E}$ fázisváltozással rendelkező impulzusokból álló sorozatot 
Fourier-transzformáljuk, egy $f_{\text {rep }}$ beosztású frekvenciafésüt kapunk, amely minden foga azonos $f_{C E O}$ offszettel rendelkezik (II.4. ábra). A II.4. ábra alapján belátható, hogy a spektrum előállítható az

$$
f_{m}=f_{C E O}+m \cdot f_{\text {rep }}
$$

összefüggés segítségével.

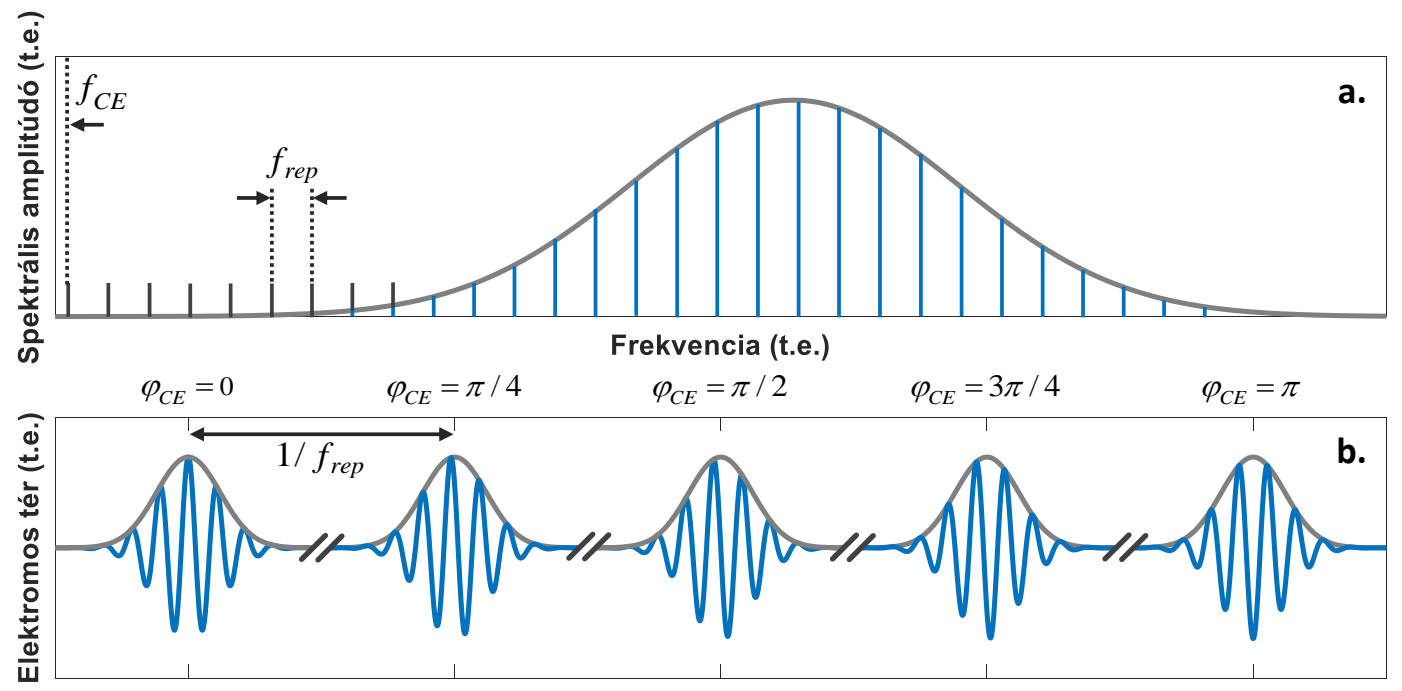

Idő (t.e.)

II.4. ábra Impulzussorozat a frekvencia (a) és az időtartományban (b). A CEP impulzusról impulzusra való csúszásának értéke azonos minden impulzus esetén, és értéke $\pi / 4$.

Az így kapott frekvenciafésű nagy jelentőséggel bír, hiszen felhasználható egy ismeretlen $f_{x}$ frekvencia meghatározására. Ugyanis, ha $f_{r e p}$ és $f_{C E O}$ ismertek, akkor az ismeretlen frekvencia és a frekvencia fésü $\Delta f$ lebegési frekvenciájának segítségével az

$$
f_{x}=f_{\text {CEO }}+m \cdot f_{\text {rep }} \pm \Delta f
$$

összefüggés alapján [30]. Ennek eredményeként a lézeroszcillátorok a frekvencia metrológia alapvető eszközeivé váltak. Fontos megjegyezni, hogy az impulzusok $\Delta \varphi_{C E}$ fázisának stabilizálása, azaz az $f_{C E O}$ frekvencia értékének rögzítése az ultrapontos frekvencia metrológia szempontjából kiemelt fontosságú [31,32]. 


\section{II.2. Ultrarövid impulzusok erősítése}

A lézerek megjelenése óta a fény és az anyag kölcsönhatásának vizsgálata óriási fejlődésnek indult. Mindennek oka, hogy az addig elérhetetlen fényintenzitás hiányában a közegeknek a fénnyel való gerjesztésre adott csupán lineáris válaszát sikerült feltérképezni. Kísérleti bizonyítást nyert azonban, ha a gerjesztő tér intenzitása kellően nagy, az addig lineáris optikai közeg új effektusokat mutat, amely a nemlineáris polarizációs válasznak köszönhetö. Az első nemlineáris effektusokat rögtön a lézer megjelenését követően, az 1960-as években demonstrálták. A beeső lézertér segítségével új frekvenciákat állítottak elő [33], optikai rektifikációt értek el [34], továbbá kimutatták egy optikai közeg törésmutatójának a lézertér hatására bekövetkező megváltozását [35]. A lézerintenzitás gyors növekedését az említett évtizedben a $Q$-kapcsolás ( $Q$-switching) [36,37], illetve a módusszinkronizáció (mode-locking) megjelenése tette lehetővé [38-40]. Az utóbbi effektus az ultrarövid impulzusok előállításának alapját képezi és alkalmazása óriási fejlődést eredményezett az elérhető lézerintenzitás növelésében [29]. A módusszinkronizáció felhasználásával az 1970-es években megszületett az első generációs femtoszekundumos technológia [41], amelyet a festéklézerek megjelenése tett lehetővé. A passzív módusszinkronizáción alapuló festéklézerek segítségével elsőként tudtak 1 ps alatti impulzushosszt előállítani [42-45]. Bár a festéklézerek fejlődésével a femtoszekundumos impulzusok előállítása is lehetővé vált [46,47], az alacsony szintü energiatárolási képességek ( $\mathrm{mJ} / \mathrm{cm}^{2}$ nagyságrendü telítési energiasủrüség) következtében az elérhető impulzusenergia, és így az intenzitás értéke is limitált volt [48]. Az impulzusok időtartamának csökkentése és a csúcsintenzitás növelése érdekében számos szilárdtest alapú erősítő közeget vizsgáltak meg az 1980-as években, amikor is az évtized végén a Ti:Sa megjelenésével [49,50], majd a módusszinkronizált Ti:Sa lézer kísérleti demonstrációjával [51] új korszak vette kezdetét.

\section{II.2.1. Fázismodulált impulzuserősítés}

Az impulzusenergia növelésével az elérhető csúcsintenzitás is jelentősen emelkedett, amely főként az erősítő közegben való terjedés során jelentett óriási problémát. Mint ismeretes, adott közeg törésmutatója megfelelően nagy intenzitás értékek esetén intenzitásfüggővé válik, amit az $n_{2}$ nemlineáris törésmutatóval szokás figyelembe venni:

$$
n(I)=n_{0}+n_{2} I,
$$

ahol $n_{0}$ a lineáris törésmutatót jelöli. A törésmutató változása az intenzitás függvényében az impulzusok spektrális és térbeli fázistulajdonságait is megváltoztatja. Az akkumulált nemlineáris fázisváltozást az ún. B-integrállal szokás megadni, amely a

$$
B=\frac{2 \pi}{\lambda} \int_{0}^{L} n_{2} I d x
$$

formulával írható fel, ahol $\lambda$ az impulzus központi hullámhossza, valamint $L$ a közeg hossza. Az impulzus térbeli intenzitás-eloszlásának torzulása a nemlineáris fázisváltozás által a B-integrállal kiszámolt értékkel megadható a nyalábkeresztmetszet mentén. A térbeli intenzitás változások mellett, az impulzus spektrális-, és így időbeli karakterisztikája is megváltozik, amely jellemzően káros impulzustorzulást jelent. A térbeli torzulás a gyakorlatban részleges-, vagy teljes önfókuszálásként jelentkezik, amely egy erősítőben katasztrofális következményekkel járhat: mind az erősítő közeg, mind 
pedig az erősítőben található optikák is sérülhetnek. Egy tökéletes Gauss-nyaláb esetén a nemlineáris fázistolás teljes önfókuszáláshoz vezet, amennyiben az impulzus csúcsteljesítménye átlépi a

$$
P_{c r}=\frac{\lambda_{0}^{2}}{2 \pi n_{0} n_{2}}
$$

kifejezéssel definiált kritikus értéket, ahol $\lambda_{0}$ a központi hullámhossz. Tipikusan a Ti:Sa alapú erősítő rendszereknél azonban az erősített nyalábban a pumpanyaláb által eredményezett intenzitás modulációk miatt a részleges önfókuszálás jelenti a legnagyobb problémát, amely forrópontok (hot spot) megjelenését okozza az intenzitás térbeli eloszlásában. A forrópontok intenzitás lokálisan nagy értéke miatt számos alkalmazás szempontjából használhatatlanná teszik a nyalábot, valamint könnyedén károsíthatják az erősítő közeget, illetve a rendszerben található optikákat is [52,53].

A hatékony erősítés létrehozásához mind a pumpa-, mind pedig az erősített impulzus energiasűrűségét megfelelően magas értéken kellett tartani. Ezzel szemben a nemlineáris törésmutató által eredményezett impulzustorzulások minimalizálása, valamint a roncsolások elkerülése miatt a nyaláb méretének növelése, illetve az erősítő közeg és minden más optikai elem apertúrájának felskálázása volt szükséges a konvencionális erősítés fenntartásához. A problémát a fázismodulált impulzuserösités (chirped pulse amplification, CPA) módszerének alkalmazása oldotta fel [54-60]. A metódus lényege, hogy az erősítendő lézerimpulzus spektrális fázisát valamilyen diszperzív elrendezésben módosítva elsőként időben kinyújtjuk az eredeti hosszának ezerszeresére, vagy nagyobb időbeli hosszra, amely révén lecsökken annak csúcsintenzitása, de az energiasürüség továbbra is megmarad. Ezzel a lépéssel elérhető, hogy a B-integrál értéke alacsonyan tartható az erősítés folyamán. Az impulzus spektrális fázisát az erősítést követően a nyújtás során felhasználttal közel azonos, de ellentétes előjelü diszperzió segítségével kompenzáljuk, amely révén időben újra összenyomva jóval nagyobb csúcsintenzitás érhető el, mint amit a közvetlen erősítés lehetővé tett volna. A CPA módszert a II.5. ábra foglalja össze.

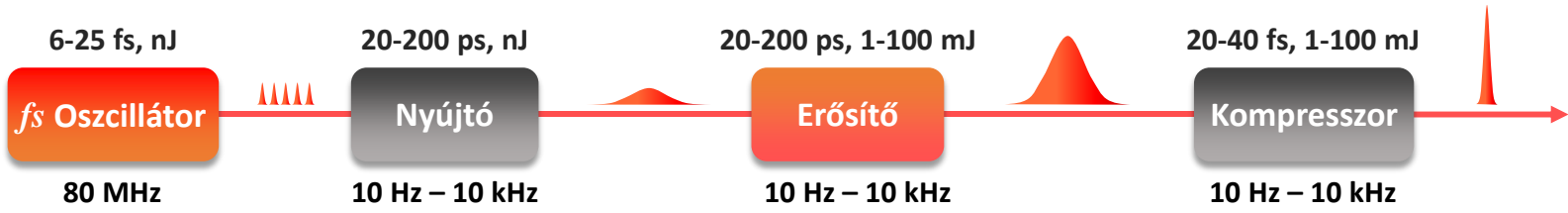

II.5. ábra A CPA technika elvi felépítése a tipikus müködési impulzusparaméterekkel az egyes részegységek esetén.

A II.5. ábrán leírt sémára épül gyakorlatilag minden nagyintenzitású lézerrendszer. Kutatási témámra való tekintettel, a Ti:Sa alapú lézerrendszerekre jellemző paramétereket tüntettem fel a II.5. ábrán jelölt alrendszerek esetén.

A femtoszekundumos Ti:Sa oszcillátorok tipikusan 70-80 MHz ismétlési frekvencián, $\mathrm{nJ}$ energiájú impulzusokat generálnak akár 6 fs időbeli hosszúsággal, és az annak megfelelő extrém nagy sávszélességgel. Az ismétlési frekvenciát az erősítést megelőzően le kell csökkenteni, ugyanis az oszcillátor teljes impulzussorozatának erősítése akár csak a mJ nagyságrendig is, extrém pumpalézer igényeket, valamint hőterhelést jelentene az erősítő fokozatokban. Az impulzusok ismétlési frekvenciájának lecsökkentését polarizációs elven, egy Pockels-cella és két polarizátor segítségével szokás elvégezni. Ezt az elérhető pumpalézer ismétlési frekvenciájának, valamint az erősítő kristály hütési kapacitásának függvényében jellemzően $10 \mathrm{~Hz}$ és $10 \mathrm{kHz}$ közötti értékre állítják be. Az erősítés értéke által igényelt mértékủ impulzusnyújtást az impulzus spektrális komponenseinek fázisviszonyát 
változtatva tipikusan 20 és 200 ps közötti impulzushosszig szokás megvalósítani, amely több módszerrel is elvégezhető: szögdiszperziós hatáson alapuló prizmás, diffrakciós rácsos elrendezések, vagy anyagi diszperzión alapuló, üvegtömbök felhasználásával. Újabb eszközként megjelentek az ún. grism impulzusnyújtók is, amelyek esetén prizmák egyik oldalán diffrakciós rács található. A nyújtást követően az impulzust akár több fokozatban felerősítjük jellemzően 6-8 nagyságrenddel, amely a néhány mJ-tól akár $100 \mathrm{~mJ}$-ig terjedő impulzusenergiát eredményez. Az erősítést két elrendezésben szokás elvégezni: a néhány $\mathrm{mJ}$ energiaszint eléréséhez regeneratív [4,61] vagy multipasszos [62,63] erősítési sémát alkalmaznak, míg a $10 \mathrm{~mJ}$ - $100 \mathrm{~mJ}$ energiák esetén már csak multipasszos elrendezést használnak [64,65]. Végül az impulzus spektrális komponenseit visszarendezve egy, a nyújtóval ellentétes előjelü diszperzióval rendelkező, jellemzően diffrakciós rácsos elrendezés segítségével az impulzust közel eredeti hosszára nyomjuk össze. Az impulzusnyújtó $\left(\varphi_{s t r}\right)$, a kompresszor $\left(\varphi_{\text {comp }}\right)$, valamint két alrendszer közötti anyagi diszperzió $\left(\varphi_{m e d}\right)$ révén akkumulált fázisra vonatkozóan jól összenyomott impulzus esetén érvényes a

$$
\varphi_{s t r}(\omega)+\varphi_{\text {med }}(\omega)+\varphi_{\text {comp }}(\omega)=0
$$

kifejezés. A (II.40) formula alapján belátható, hogy jól összenyomott, erősített impulzust akkor kapunk, ha a kompresszor spektrális fázisjáruléka megegyezik a nyújtó és az erősítés során fellépő anyagi diszperzió fázisával, csak ellentétes előjellel [53]. A (II.40) kifejezésben található fázistagokat Taylorsorba fejtve megkaphatóak az egyes alrendszerekhez tartozó fázisderiváltak értékei, amelyekre vonatkozóan elmondható, hogy jól összenyomott impulzust csak akkor kaphatunk, ha nem csak a GDD, hanem a TOD, sőt az FOD is jól kompenzált a kompresszor révén. Gyakran azonban a magasabb rendü fázisderiváltak nem kompenzálhatóak ki tökéletesen a kompresszor révén. Pontos korrekciót az ún. akuszto-optikai programozható diszperziós szürök (acousto-optic programmable dispersive filter, $A O P D F)$ segítségével lehet elvégezni [66].

\section{II.2.2. Ultrarövid impulzusok erősítése Ti:Sa kristályban}

A Ti:Sa kristály lézerközegként való alkalmazásának első demonstrációja óta nagyszámú vizsgálat tárgyát képezi, és napjainkban is az ultrarövid impulzusokat előállító lézerrendszerek legelterjedtebb erősítő közege.
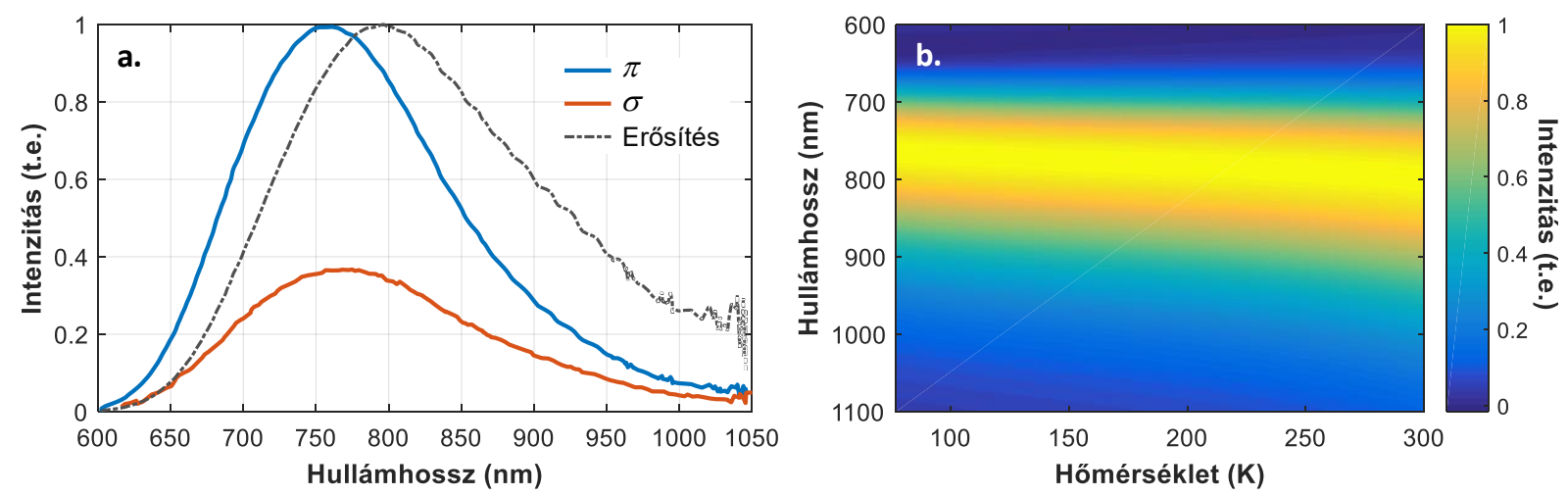

II.6. ábra Ti:Sa szobahőmérsékleten mért fluoreszcencia spektruma a $\pi$ - és a $\sigma$-polarizáció irányában, illetve az erősítési spektrum a $\pi$-polarizációra (a) [50]. Az erősítési spektrum változása a hőmérséklet változása esetén 77 K és 300 K között Poisson-eloszlással közelítve [67].

Ennek egyik fö oka a kristály rendkívül széles, közelítőleg 600 és $1100 \mathrm{~nm}$ közötti emissziós spektruma (II.6. ábra, (a) rész) és nagy stimulált emissziós hatáskeresztmetszete, amely révén jól használható 
szélessávú impulzusok keltésére és erősítésére is. A jóval nagyobb abszorpciós és erősítési hatáskeresztmetszet miatt a $\pi$-polarizációs irány használata a tipikus a Ti:Sa kristályok esetén. Fontos, hogy a Ti:Sa fluoreszcencia és erősítési spektruma a hőmérséklet csökkenése esetén eltolódik az alacsonyabb hullámhosszak felé [67], valamint a szélességük lecsökken (II.6. ábra, (b) rész). A $490 \mathrm{~nm}$ körüli maximummal rendelkező abszorpciós spektruma hatékonyan pumpálhatóvá teszi például Nd:YAG, vagy Nd:YLF lézerek másodharmonikusa segítségével. A Ti:Sa legfontosabb optikai, spektroszkópiai, lézer és fizikai tulajdonságait a II.1. táblázat foglalja össze. Az abszorpciós tulajdonságokat tovább vizsgálva, a látható tartományban fekvő abszorpciót meghatározó $\mathrm{Ti}^{3+}$ ionok koncentrációja relatíve tág határok között változtatható a zafír hordozó megfelelő adalékolásával [68].

II.1. táblázat Ti:Sa kristály optikai, spektroszkópiai, lézer aktivitási, illetve fizikai tulajdonságai.

\begin{tabular}{|c|c|c|c|}
\hline Tulajdonság & Érték & Mértékegység & Referencia \\
\hline \multicolumn{4}{|l|}{ Törésmutató (800 nm, $293 \mathrm{~K})$} \\
\hline$n_{o}$ & 1,7601 & & {$[70,71]$} \\
\hline$n_{e}$ & 1,7522 & & {$[70,71]$} \\
\hline Nemlineáris törésmutató & $2,9 \cdot 10^{-16}$ & $\mathrm{~cm}^{2} / \mathrm{W}$ & [72] \\
\hline$S G D D_{o}(800 \mathrm{~nm})$ & 580 & $\mathrm{fs}^{2} / \mathrm{cm}$ & {$[70,71]$} \\
\hline$S G D D_{e}(800 \mathrm{~nm})$ & 566 & $\mathrm{fs}^{2} / \mathrm{cm}$ & {$[70,71]$} \\
\hline Abszorpciós spektrum csúcsértéke (300 K) & 490 & $\mathrm{~nm}$ & [50] \\
\hline$\sigma_{a, \pi}$ & $6,5 \cdot 10^{-20}$ & $\mathrm{~cm}^{2}$ & [50] \\
\hline$\sigma_{a, \sigma}$ & $2,8 \cdot 10^{-20}$ & $\mathrm{~cm}^{2}$ & [50] \\
\hline Emissziós spektrum csúcsértéke (300 K) & 795 & $\mathrm{~nm}$ & {$[50,73]$} \\
\hline$\sigma_{e, \pi}$ & $3,9 \cdot 10^{-19}$ & $\mathrm{~cm}^{2}$ & {$[50,73]$} \\
\hline$\sigma_{e, \sigma}$ & $1,6 \cdot 10^{-19}$ & $\mathrm{~cm}^{2}$ & {$[50,73]$} \\
\hline Fluoreszcencia idötartam (300 K) & 3,15 & $\mu \mathrm{s}$ & [50] \\
\hline Emissziós spektrum félértékszélessége (300 K) & 225 & $\mathrm{~nm}$ & {$[50,67]$} \\
\hline Telitési energiasürüség & 0,84 & $\mathrm{~J} / \mathrm{cm}^{2}$ & [74] \\
\hline \multicolumn{4}{|l|}{ Kvantum hatásfok: } \\
\hline$\eta_{q}(300 \mathrm{~K})$ & 0,8 & & [50] \\
\hline$\eta_{q}(77 K)$ & $\sim 1$ & & {$[50]$} \\
\hline \multicolumn{4}{|l|}{ Hövezetési együttható: } \\
\hline$k(300 \mathrm{~K})$ & 35 & $\mathrm{~W} / \mathrm{m} / \mathrm{K}$ & [75] \\
\hline$k(77 K)$ & $10^{3}$ & $\mathrm{~W} / \mathrm{m} / \mathrm{K}$ & [75] \\
\hline$k(35 K)$ & $1,6 \cdot 10^{4}$ & $\mathrm{~W} / \mathrm{m} / \mathrm{K}$ & [76] \\
\hline
\end{tabular}

Fontos azonban megemlíteni, hogy a szennyezés kialakítása során $\mathrm{Ti}^{4+}$ ionok is bejutnak a hordozóba, amelyek a közeli infravörös tartományban nem kívánt abszorpciót eredményeznek, és a szélessávú lézermüködést lerontják. Ezt az effektust megfelelő növesztési technikával és utólagos gyártási eljárásokkal lehetséges kompenzálni, így magas optikai és lézer minőségű kristályokat lehet elöállítani [77]. A Ti:Sa kristályban létrejövő lézermüködés négyszintes energiarendszerrel írható le [52]. Mivel a Ti:Sa kettőstörő kristály, a II.1. táblázatban a spektroszkópiai tulajdonságokat a $\pi$ - és a $\sigma$-polarizációs irányok mentén is megadtam. A spektroszkópiai- és lézerparaméterei mellett nagy jelentőségü, hogy magas szobahőmérsékleti hővezetési együtthatóval rendelkezik (zafír hordozó tulajdonsága), amely az abszorbeált pumpateljesítményből disszipálódó hő hatékony leadása szempontjából elengedhetetlen. 
Kutatói tevékenységem során született eredményeim a Ti:Sa alapú erősítő fokozatok tulajdonságaival, illetve azok tovább fejlesztéseivel kapcsolatosak, így elengedhetetlennek tartom, hogy az ultrarövid impulzusok lézererősítésének elméleti alapjait bemutassam. Az erősítés folyamatának megértéséhez érdemes elsőként egydimenziós esetben kezelni a problémát. Ekkor az erősítő közeget rezonáns, kétszintes rendszerként kezelve meg kell oldanunk a Maxwell-egyenleteket az elektromos térerősségre nézve [78,79]. A megoldás során megkapjuk az elektromos tér terjedését, a makroszkopikus polarizációt, valamint a populáció inverziót leíró egyenleteket. Bevezetve a $T_{1}$ és $T_{2}$, úgynevezett longitudinális és transzverzális relaxációs időket, az egyenletek megoldásának egyszerüsítéséhez bizonyos feltételezésekkel élhetünk. A $T_{1}$ mennyiség nem más, mint az ion gerjesztett állapotának időtartama, míg a $T_{2}$ mennyiség pedig az ion-fonon kölcsönhatás által meghatározott időtartam. Lézeraktív kristályokban a $T_{1} \gg T_{2}$ reláció érvényes, mégpedig a Ti:Sa közeg esetén $T_{1} \approx$ $\mu s$, valamint $T_{2} \approx p s$ időbeli tartományokba esik. Feltéve, hogy az erősítendő impulzus burkolójának és a közegbéli populáció inverziónak a változása a $T_{2}$ idő alatt elhanyagolható, akkor a tér terjedésére és a populáció inverzióra a

$$
\begin{aligned}
& \frac{\partial I}{\partial t}+c \frac{\partial I}{\partial z}=c \sigma_{e}(\omega) N \cdot I, \\
& \frac{\partial N}{\partial t}=-c \cdot \frac{\gamma \sigma_{e}(\omega)}{\hbar \omega} N \cdot I,
\end{aligned}
$$

egyenleteket nyerjük, ahol $I \equiv\left(\varepsilon_{0} c / 2\right)|E|^{2}$ a tér intenzitása, $N$ a populáció inverzió, $\sigma_{e}(\omega)$ a lézerközeg emissziós hatáskeresztmetszete, $c$ a közegbéli fénysebesség, $\gamma$ pedig egy általánosítási faktor. Négyszintes rendszer esetén, mint a Ti:Sa, $\gamma=1$ érvényes. A (II.41) és (II.42) egyenletekből integrálás segítségével megkapható az

$$
I(z, t)=I_{0}(t) \cdot\left[1-\left(1-\frac{1}{G_{0}}\right) \exp \left(-\frac{J_{0}(t)}{J_{s a t}}\right)\right]^{-1},
$$

összefüggés, amely az intenzitást adott $z$ pontban adja meg az erősítő közegben való terjedés során [80]. A (II.43) összefüggés a bemeneti $I_{0}(t)$ intenzitás és a közeg paramétereinek függvényéven adja meg az impulzus intenzitásának fejlődését, és Frantz-Nodvik egyenletnek szokás nevezni. Jelöljük $\sigma_{e r}$-rel az emissziós hatáskeresztmetszet rezonanciánál (emissziós spektrum csúcsánál) felvett értékét, amely segítségével felírható a

$$
G_{0}=\exp \left[\sigma_{e r} \int_{0}^{z} N\left(z^{\prime}\right) d z^{\prime}\right]
$$

kisjelü erősítés. Továbbá $J_{s a t}=\hbar \omega_{e r} /\left(\sigma_{e r} \gamma\right)$ az úgynevezett telítési energiasürüség, valamint a beeső impulzus pillanatnyi energiasürüsége $J_{0}(t) \equiv \int_{0}^{t} I_{0}\left(t^{\prime}\right) d t^{\prime}$, amely az egységnyi területen áthaladó fotonok száma a $t$ időpillanatig, és $t \rightarrow \infty$ határesetben a beeső impulzus energiasürüsége lesz [74]. A (II.43) kifejezés alkalmas a monokromatikus impulzusok erősítő közegen való egyszeri áthaladásának elemzésére, azonban a gyakorlati alkalmazásokban sokpasszos elrendezések szükségesek a kívánt erősítés eléréséhez. Továbbá, az ultrarövid impulzusok széles spektrummal rendelkeznek, valamint az előző alfejezetben említett limitációk miatt fázismoduláltak is. Emiatt érdemes az előzőekben felírt 
egydimenziós modellt kiegészíteni többpasszos elrendezésekre, valamint a CPA sémának megfelelően a fázismodulált impulzusok kezelésére.

A többpasszos erősítés leírásához az erősítendő impulzus közegen való áthaladása után meg kell határozni a megmaradó kisjelü erősítés értékét. Ha az $n$-edik passzban mérhető $G_{0}^{(n)}$ kisjelű erősítés és $I^{(n)}(t)$ intenzitás profil ismertek, akkor az $n+1$-edik passzban az erősítő közeg teljes $z=L$ hossza után a kisjelü erősítésre a

$$
G_{0}^{(n+1)}=\exp \left[\frac{J_{\text {sat }} \ln \left(G_{0}^{(n)}\right)-\left(J_{0}^{(n+1)}(\infty)-J_{0}^{(n)}(\infty)\right)}{J_{\text {sat }}}\right]
$$

alakú kifejezést kapjuk, ahol az exponensben lévő első tag a közegben az $n$-edik passz előtt tárolt energiasürüséget, míg a második tag pedig az $n+1$-edik passzban kicsatolt energiasürüséget jelenti. Mivel pedig az egyes erősítő közegen való átmenetek között az impulzus erősítőn belüli reflexiói révén, valamint a kristály felületén is veszteségek léphetnek fel, amelyeket figyelembe kell venni az erösítés kiszámítása során. A (II.43) összefüggést szokás még a kimeneti energiasürüségre vonatkozóan felírni, amely így a

$$
J_{L}(t=\infty)=J_{\text {sat }} \cdot \ln \left[1+G_{0}\left(\exp \left(\frac{J_{0}(t=\infty)}{J_{\text {sat }}}\right)-1\right)\right]
$$

alakú kifejezést kapjuk, amely jól használható többpasszos erősítők modellezésére. A (II.46) összefüggés alapján az erősítő müködésének két tartományát tudjuk megkülönböztetni. Amennyiben a beeső impulzus energiasürúsége jóval kisebb, mint a telítési energiasürüség, valamint ebből következően $G_{0} J_{0} / J_{\text {sat }} \ll 1$, a (II.46) kifejezés alapján az erősítés a

$$
G \approx G_{0}
$$

alakra egyszerüsödik. Ebben az esetben az erősítés exponenciálisan növekszik az erősítő közeg hosszával. Nagy beeső energiasürüség esetén, amelyre $J_{0} / J_{\text {sat }} \gg 1$, az erősítés a

$$
G \approx 1+\frac{J_{\text {sat }}}{J_{0}} \ln \left(G_{0}\right)
$$

összefüggést nyerjük [52]. A (II.48) kifejezésből jól látható, hogy az erősítés nagy beeső energiasűrűségek esetén az erősítő közeg hosszával már csak lineárisan növekszik: az erősítő ilyen típusú működését nevezzük telítődésnek. Ebben az esetben az erősítő hatékonysága maximális, azaz a tárolt energiából a közeg által megengedett legnagyobb mennyiséget konvertáljuk erősített impulzusenergiává. Érdemes továbbá megemlíteni, hogy a gyakorlatban a telítődés azt is jelenti, hogy az erősítés kevésbé lesz érzékeny a beeső impulzus energiájára, amely a működés stabilitását maximalizálja.

Az erősítés leírásának további kiegészítéséhez fázismodulált impulzusok esetére szükséges az emissziós hatáskeresztmetszet frekvenciafüggésének ismeretében a $G_{0}(\omega)$ kisjelủ erősítés és a $J_{\text {sat }}(\omega)$ telítési energiasürúség frekvenciafüggését implementálni a (II.43) összefüggésbe. Továbbá, mivel a nagy intenzitású erősítők előtt az impulzusokat eredeti 10 fs körüli hosszukhoz képest $10^{3}-10^{4}$ faktorral megnyújtják, a pillanatnyi frekvenciát érdemes $\omega(t)=\omega_{0}+2 b t$ alakban felírni, ahol $\omega_{0}$ a központi frekvencia, és $b$ az úgynevezett lineáris fázismodulációs vagy csörp együttható. A csörp együtthatót a

$$
b=\frac{\Delta \omega}{2 \tau_{s t r}}=\frac{\pi c \Delta \lambda}{\tau_{s t r} \lambda_{0}^{2}}
$$


kifejezés segítségével számolhatjuk ki, ahol $\tau_{s t r}$ a kinyújtott impulzus időbeli félértékszélessége, míg $\Delta \omega$ és $\Delta \lambda$ az impulzus spektrumának frekvencia- és hullámhosszbéli félértékszélessége. A kisjelü erősítés frekvenciafüggésére a

$$
G_{0}(\omega)=\exp \left(\frac{\hbar \omega N_{0} L}{J_{\text {sat }}(\omega)}\right)=\exp \left(\frac{J_{\text {sto }}(\omega)}{J_{\text {sat }}(\omega)}\right)
$$

összefüggés nyerhető, ahol $J_{s t o}(\omega)$ a már említett tárolt energiasürüség:

$$
J_{\text {sto }}(\omega)=A \cdot J_{p} \eta_{c} \frac{\lambda_{p}}{\lambda_{0}}
$$

amelyben $A$ a kristály teljes hosszán vett pumpaabszorpció, $J_{p}$ a pumpanyaláb energiasürüsége, $\eta_{c}$ az úgynevezett kvantum hatásfok, valamint $\lambda_{p}$ a pumpa hullámhossza. A kvantum hatásfok az adott közegre jellemző paraméter, amely leírja a nem sugárzás alapú átmenetek okozta veszteségek arányát [81]. Az így kapott modell a kísérletekkel jellemzően a kisjelü erősítés tartományában jól egyező eredményeket szolgáltat, azonban a telítődés tartományában eltérések mutatkoznak a laboratóriumi mérésekből származó eredményekhez képest. Az eltérések egyértelmüen a transzverzális nyalábprofil elhanyagolásának, valamint az erősítés során fellépő torzító hatások megjelenésének köszönhetőek [74]. Az mérésektől való eltérések megértéséhez tekintsük át röviden az erősités során fellépő impulzustorzulásokat.

Bármely lézerközegbéli erősítés során az impulzusok torzulásokat szenvednek a térbeli, spektrális és időbeli tartományokban. Mivel a jelen munkában ismertetésre kerülő eredmények mindegyike a Ti:Sa alapú rendszerekhez köthető, az ilyen lézerekben előforduló fontosabb torzulásokat a II.7. ábrán soroltam fel [52].

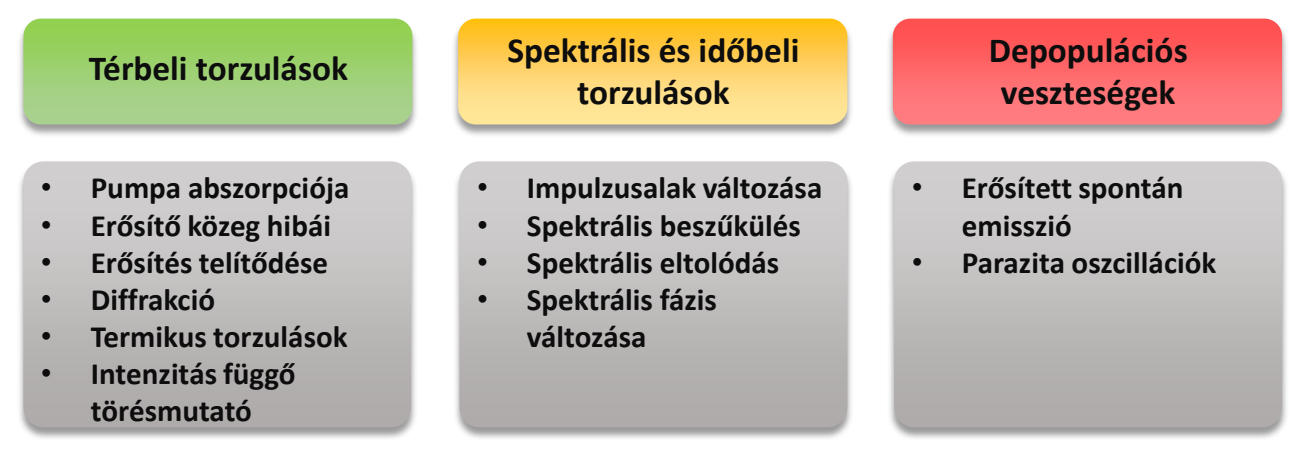

II.7. ábra Erősített impulzusok térbeli, spektrális és időbeli torzulásai, valamint az erősítés veszteségei.

A térbeli torzulásokkal kezdve, a pumpanyaláb profilja a kristályban pumpált térfogatában létrejövő populáció inverzió homogenitását alapvetően meghatározza. Amennyiben a pumpanyaláb intenzitás eloszlása aszimmetrikus, vagy nem kívánt csúcsokat tartalmaz, az inhomogenitások az invertált közegen való áthaladás során az erősítendő impulzusokban is megjelennek az erősítés térfüggése által. Az optimális erősítés elérése az négyszög alakú (flat-top) térbeli intenzitás eloszlású pumpaimpulzusok segítségével lehetséges, amely homogén invertált térfogatot eredményez az erősítő közeg belsejében. Érdemes megemlíteni, hogy az erősítő közeg belsejében a gyártás során keletkező inhomogenitások, például a kristály rácshibái, vagy a szennyező fémionok nem egyenletes eloszlása az erősítést nagymértékben befolyásolják. Az utóbbi két évtizedben a Ti:Sa kristályok magas minőségü előállítása rutinszerü feladattá vált [68], amely révén az imént említett problémák gyakorlatilag eliminálhatóak. Az erősítés folyamán fellépő telítődés szintén módosíthatja az erősítendő impulzusok térbeli intenzitás eloszlását, amelyet az erősítés térbeli eloszlásának változása eredményez. Ha ugyanis a bejövő impulzus 
energiasürüsége összemérhető a telítési energiasürüséggel, az impulzus gyengébb intenzitású részei, általában a nyaláb szélei, jobban fognak erősödni, mint a központi rész. Az erősítőkben fellépő diffrakció bármely optikán való levágás, vagy szándékos apertúra elhelyezésre révén szintén káros lehet az erősített impulzus térbeli profiljára. Ezeket jellemzően az erősítő fokozat körültekintő tervezésével el lehet kerülni, azonban bizonyos esetekben apertúrák elhelyezése indokolt lehet, amely Fresnel-gyürük megjelenését eredményezheti. Két további térbeli torzító hatást érdemes még megemlíteni, amelyek azonban kiemelést érdemelnek. Az egyik ilyen effektus az erősítő kristály pumpált térfogatában a pumpaenergia hőként való disszipációja révén létrejövő termikus lencsehatás, valamint hullámfront torzulás. A pumpanyaláb intenzitásának inhomogén eloszlása jellemzően a pumpált térfogat centruma felé magasabb, míg a szélek felé alacsonyabb hőmérsékletet eredményez a kristályban, amely olyan törésmutató profilt eredményez, amely révén a közeg lencseként müködik. A hőmérsékletprofil inhomogenitása miatt mechanikai feszültségek léphetnek fel, amelyek további torzító hatást fejthetnek ki az impulzusokra. A másik kiemelten kezelendő torzító hatás az erősítő közeg törésmutatójának intenzitásfüggése révén kialakuló törésmutató változás, amely a nagyintenzitású erősítőkben jellemző. Ekkor az erősítendő impulzus olyan megváltozott törésmutató profilt érzékel, amely képes lefókuszálni az impulzust. Ezt az effektust nevezzük önfúkuszálásnak (self-focusing), amely jelentkezhet a teljes nyalábra vonatkozóan, vagy a nyalábkeresztmetszet egyes részleteire nézve is. Az utóbbi forrópontok megjelenését, filamentációt, illetve végső soron a nyaláb szétesését eredményezheti [52].

Térjünk most át az erősítés során fellépő spektrális és időbeli impulzustorzulásokra, amelyek az erősítés után elérhető csúcsintenzitást alapvetően befolyásolják. Az erősítő közeg erősítési spektruma véges, a frekvencia mentén nem egyenletes, a spektrum maximumától távolodva a széleken erősen lecsökken. Mindaddig, amíg az erősítendő impulzus spektruma kis sávszélességü, és a közeg erősítési spektrumának lassan változó centrumához közel esik, az erősített spektrum a bemenővel közel azonos szélességü lesz. Ha azonban az előbbi feltétel sérül, miszerint az erősítendő impulzus spektruma kellően széles, az erősítőben való terjedés során az impulzus spektruma beszükül, hiszen a spektrum szélei jóval kevésbé erősödnek, mint a központi része. Ezt az effektust nevezzük spektrális beszükülésnek (gain narrowing). A beszükült spektrum eredményeként az erősített impulzusok már nem nyomhatóak össze az eredeti hosszukra, s így az időbeli hossz megnő. Mivel ez az effektus megszabja az erősített impulzusok elérhető legrövidebb időbeli hosszát, a Ti:Sa alapú rendszerek egyik legnagyobb limitációját is jelenti. További fontos effektus az ún. spektrális eltolódásnak (gain shifting), amit az erősítés során fellépő telítődés hoz létre. Mivel az impulzus elülső fele nagyobb erősítést fog látni, mint a hátsó fele, köszönhetően az elülső fél által már kicsatolt energiának, az erősen fázismodulált impulzus spektruma el fog tolódni. Emellett a telített erősítőkben a spektrum centrális része már kevésbé erősödik, mint a spektrum szélei, így a szélek a centrumhoz viszonyított eredeti intenzitásukhoz képest megemelkednek. Ezáltal a spektrum a jellemzően Gauss-típusú bemeneti profilból flat-top alakúvá válik. Ti:Sa erősítők esetén általában a hosszabb hullámhossz felé tolódik el az erősített impulzusok spektruma [82]. Fontos figyelembe venni továbbá, hogy az erősítő közeg diszperziója révén módosítja az erősítendő impulzus spektrális fázisát. Konkrétan a közeg lineáris diszperziója révén a jelentősebb diszperziós rendeket tekintve GDD-t és TOD-t ad hozzá az impulzus spektrális fázisához, amelyeket egy CPA rendszer tervezése esetén figyelembe kell venni. Ha az erősített impulzusok csúcsintenzitása kellően nagy, az erősítő közegben fellépő nemlineáris fázistorzítás rendkívül megnehezítheti az impulzusok későbbi időbeli összenyomását.

Érdemes külön kezelni az erősítő kristályban fellépő nem kívánt, úgynevezett parazita effektusokat a tér- és időbeli torzulásoktól. Ezek a depopulációs veszteségek ugyanis az adott közeg felső 
energiaszintjének élettartamától, geometriájától és az adott erősítőben fellépő erősítéstől függenek. Jellemzően a legnagyobb problémát az erösitett spontán emisszió (amplified spontaneous emission, $\boldsymbol{A S E}$ ) okozza az erősítők jelentős részében. Nagymértékű ASE kialakulásához előnyös a nagy erősítés és nagy erősítő közegbéli úthossz együttes jelenléte az adott erősítőben. Fontos, hogy az ASE kialakulásához nem lehet küszöbértéket rendelni például a szükséges pumpaintenzitásra vonatkozóan. Amennyiben az erősítő kristály egy pontjából adott térszögben kiinduló ASE a közeg felületeiröl való reflexiók révén nagy úthosszat tud bejárni, annak intenzitása jelentős mértékben meg tud emelkedni. Ekkor a populáció-inverzió olyan szinten lecsökkenhet a megnövekvő ASE által, hogy az erősítő hatékonysága jelentősen lecsökkenhet.

\section{II.2.3. Optikai parametrikus erősítők}

A Ti:Sa alapú CPA rendszerek limitált impulzushossza és rögzített spektrális tartománya korlátokat szabnak az alkalmazhatóság tekintetében. Számos lézer-anyag kölcsönhatás vizsgálatához, mint például a magasharmonikusok keltése, illetve a femtoszekundumos pumpa-próba spektroszkópia esetén azonban spektrálisan hangolható forrásra lehet szükség, amely akár néhány ciklusos impulzusok előállítására is alkalmas [83]. Ennek eredményeként az utóbbi két évtizedben jelentős figyelem fordult az optikai parametrikus erösitésen (optical parametric amplification, $\boldsymbol{O P A}$ ) alapuló fényforrások fejlesztésére.

Az OPA folyamat során egy nem nulla $\chi_{2}$ szuszceptibilitással rendelkező nemlineáris kristályban egy nagyobb körfrekvenciájú és intenzitású pumpaimpulzus $\left(\omega_{p}\right)$ energiája átadódik a kisebb körfrekvenciájú és intenzitású magimpulzusnak $\left(\omega_{s}\right)$, továbbá egy harmadik impulzus is keltődik $\left(\omega_{i}=\right.$ $\omega_{p}-\omega_{s}$ ), amit idler-nek nevezünk (II.8. ábra, (a) rész). A parametrikus erősítést szokás a lézermüködéshez hasonlóan, virtuális energiaszintekkel leírni: az $\omega_{p}$ foton a kristályt az alapállapotból egy virtuális gerjesztett állapotba juttatja, majd az $\omega_{s}$ és $\omega_{i}$ körfrekvenciájú fotonok kibocsátásával visszajutunk az alapállapotba (II.8. ábra, (b) rész).

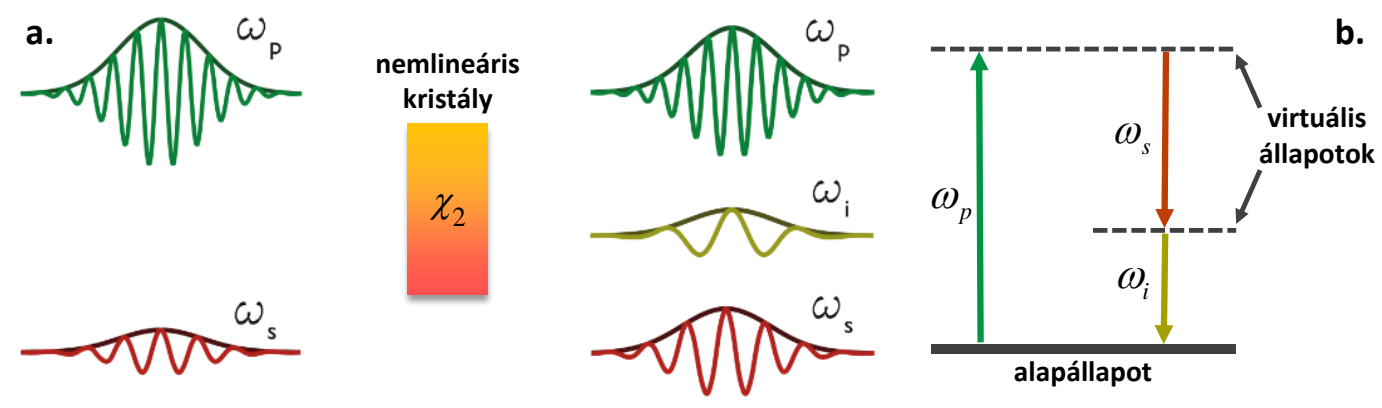

II.8. ábra A beeső és a kimenő elektromos terek az OPA folyamat során (a), illetve a foton interpretáció szemléletes képe a virtuális energiaszintekkel [84].

A nemlineáris kristályban lejátszódó kölcsönhatásra felírva az energia megmaradását a

$$
\hbar\left(\omega_{p} \pm \Delta \omega_{p}\right)=\hbar\left(\omega_{s} \pm \Delta \omega_{s}\right)+\hbar\left(\omega_{i} \pm \Delta \omega_{i}\right)
$$

egyenletet kapjuk. A magimpulzus központi frekvenciája elméletben $\omega_{p} / 2$ (ún. degenerációs állapot, amelyre $\omega_{s}=\omega_{i}$ ) frekvenciától egészen $\omega_{p}$ értékig változhat, amelynek megfelelően az idler központi frekvenciája $\omega_{s} / 2$ és 0 közötti értéket vehet fel. A mag- és pumpaimpulzusok központi frekvenciájának megválasztását erősen limitálhatja az egyes nemlineáris kristályok abszorpciója [83]. Mivel az ultrarövid impulzusok meghatározott spektrális sávszélességgel rendelkeznek, a (II.51) egyenletben ezt 
a $\Delta \omega_{p}, \Delta \omega_{s}$, illetve $\Delta \omega_{i}$ tagokkal vesszük figyelembe. Az energia megmaradása mellett a parametrikus erősítés során teljesülnie kell az impulzus megmaradásának is, amelyre vonatkozóan felírható a

$$
\vec{k}_{p} \pm \Delta \vec{k}_{p}-\left(\vec{k}_{s} \pm \Delta \vec{k}_{s}\right)-\left(\vec{k}_{i} \pm \Delta \vec{k}_{i}\right)=\Delta \vec{k}
$$

egyenlet a pumpa $\left(\vec{k}_{p}\right)$, seed $\left(\vec{k}_{s}\right)$ és idler $\left(\vec{k}_{i}\right)$ impulzusok hullámszám vektoraival. A spektrális sávszélesség ebben az esetben is fontos tényező, amit a (II.53) egyenletben a $\Delta \vec{k}_{p}, \Delta \vec{k}_{s}$, illetve $\Delta \vec{k}_{i}$ vektorokkal veszünk figyelembe [84]. A (II.53) egyenlet az ún. fázisillesztés (phase matching) elvét fogalmazza meg, amely az egyes impulzusok kristálybéli terjedésének irányára vonatkozóan ad megszorítást. Az optikai parametrikus erősítés teljes körủ matematikai leírásával kapcsolatban számos publikációt találhatunk az irodalomban, ezek közül az olvasó például a [72,85] müvekben tájékozódhat. Fontos megemlíteni, hogy a fázisillesztés alapvetően meghatározza az OPA elrendezés geometriáját: a pumpa- és magimpulzusok párhuzamos terjedése esetén kollineáris, míg szöget bezáró terjedés esetén nemkollineáris fázisillesztést kapunk. Az utóbbi nagy jelentőségét az adja, hogy ultraszéles spektrális tartományon tesz lehetővé erösítést. A nemkollineáris optikai parametrikus erősitők (noncollinear optical parametric amplification, NOPA) segítségével kompakt módon, a látható tartománytól a közeli infravörös hullámhosszakig képesek CEP-stabil ultrarövid impulzusokat elóállítani [86-88].

A néhánytól a több $10 \mathrm{~mJ}$ energiájú, néhányszor 10 fs hosszúságú impulzusokat előállító Ti:Sa alapú CPA rendszereket gyakran további parametrikus erősítő fokozatokkal kombinálva használják, amelyek segítségével különböző központi hullámhosszú ultrarövid impulzusok nyerhetőek az UV-tól egészen a középinfravörös tartományig, akár hangolható módon is [89-92]. Ezekben jellemzően a mag- és a pumpaimpulzust is a CPA frontend biztosítja. Sok esetben azonban a femtoszekundumos tartományba eső pumpaimpulzusok nem állnak rendelkezésre. Ekkor a hosszabb, több ps, vagy ns tartományba eső pumpaimpulzusok nem teszik lehetővé a femtoszekundumos magimpulzusok hatékony erősítését, mivel az utóbbiak túl rövid időtartama lekorlátozza az OPA folyamatot a pumpaimpulzus egy kis időbeli részére. Ezen felül, a nemlineáris fázis akkumulációjának, illetve az optikák sérülésének elkerülése az energetikus impulzusok elóállításához ebben az esetben is elengedhetetlen. Ebből kifolyólag a magimpulzust időben ki kell nyújtani, hogy pumpa időbeli hosszával közel egyező impulzushosszt kapjunk. Az erősítés után természetesen az impulzust újra kompresszálni kell a legnagyobb csúcsintenzitás eléréséhez: az így kapott elrendezést optikai parametrikus fázismodulált erősitésnek nevezzük (optical parametric chirped pulse amplification, $\boldsymbol{O P C P A}$ ), amely általános elvi felépítése a II.9. ábrán látható.

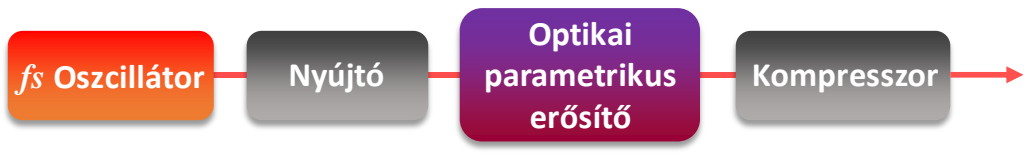

II.9. ábra OPCPA rendszer elvi felépítése.

Az OPCPA technológia az ultranagy intenzitású impulzusok előállítását is lehetővé teheti. Több nagyméretű projekt célja az ezen a sémán alapuló, PW csúcsteljesítményü impulzusok generálására alkalmas architektúra megvalósítása, bizonyos esetekben akár hibrid módon a Ti:Sa erősítés felhasználásával [12,15]. Az OPCPA rendszerek esetén a hangolhatóság mellett fontos előny lehet, hogy az OPA folyamat során a pumpaenergia nem tárolódik az erősítő közegben, így a disszipált hő mennyisége a Ti:Sa erősítőkhöz viszonyítva minimális értékü. Éppen ezért, a $10 \mathrm{kHz}$ és az annál magasabb ismétlési frekvenciájú, femtoszekundumos erősítő rendszereket gyakran OPCPA 
architektúrára építik. A diódapumpált szilárdtest (diode-pumped solid-state, DPSS) lézerek rohamos fejlődése az utóbbi tíz évben jelentősen hozzájárult az OPCPA fényforrások elterjedéséhez, mivel kellően stabil pumpaimpulzusokat tudnak biztosítani. Az ultraszélessávú OPCPA alapú fényforrások jelentős mérföldkövét jelentik például az ELI-ALPS középinfravörös (MIR) és néhány ciklusú lézerei (SYLOS), amelyek az elektromágneses spektrum különböző részein CEP-stabil impulzusokat állítanak elő $[16,93]$.

Fontos azonban kiemelni, hogy az OPCPA alapú nagyenergiájú erősítő rendszerek létrehozását több tényező jelentősen hátráltatja. Az egyik ilyen probléma a megfelelően rövid, kiváló idő- és térbeli profillal rendelkező pumpaimpulzusok biztosítása. A 10 TW feletti csúcsteljesítményü impulzusok előállításához szükséges OPCPA erősítő fokozatok meghajtásához szükséges pumpalézerek ugyanis jelenleg nem elérhetőek. Másik fontos probléma az erősítendő- és a pumpaimpulzusok időbeli szinkronizálásának stabilitása, amelyre az OPCPA erősítés különösen érzékeny.

\section{II.2.4. Kétfokozatú CPA}

A 100 TW - PW csúcsteljesítményü impulzusok anyaggal való kölcsönhatása során kiemelten fontos, hogy az impulzus időbeli intenzitásalakja milyen lefutású az impulzus elülső és hátulsó oldalán, azaz mekkora az időbeli elö- és utóimpulzus intenzitáskontraszt értéke. A legtöbb alkalmazás szempontjából a föimpulzus előtti intenzitásprofil fontos, amit előimpulzus-kontrasztnak nevezünk. Amennyiben egy $10^{19}-10^{22} \mathrm{~W} / \mathrm{cm}^{2}$ fókuszált intenzitású impulzus anyaggal lép kölcsönhatásba, az előimpulzus kontraszt értéke legalább $10^{12}$ kell legyen, hogy elő-plazma képződés ne lépjen fel. Fontos azonban, hogy a nagyintenzitású impulzusok előállítására használt Ti:Sa CPA rendszerek tipikus előimpulzus-kontrasztja $10^{5}-10^{7}$ értékü. A CPA rendszerek fényforrásaként legtöbbször használt Kerrlencsés módusszinkronizációjú (Kerr-lens mode-locking) Ti:Sa oszcillátorok impulzusainak az időbeli kontrasztja a relatíve magas $10^{10}$ értéket is eléri. Az erősítőben a kicsiny bemeneti impulzusenergia miatt $10^{6}-10^{8}$ erősítési faktor lép fel, amely intenzív ASE megjelenéséhez, azaz a zaj felerősödéséhez vezet. Az időbeli kontrasztot az ASE mellett az optikai elemeken, föként a diffrakciós rácsokon való szóródások, illetve a rendszerből származó utóimpulzusok, valamint ezeknek a kompresszort követően előimpulzusokként való megjelenése korlátozza [94,95].

Az időbeli kontraszt javítására és az impulzusenergia további növelésére a leginkább használt séma az ún. kétfokozatú CPA (double chirped pulse amplification, DCPA), amely a nevéből adódóan egy CPA rendszer után egy második, hasonló architektúrára épülő elrendezést foglal magában. Ami azonban a névből nem következik triviálisan, hogy az első CPA fokozat után az erősített és kompresszált impulzusok egy tér- és időszürő elrendezésen haladnak keresztül, mielőtt beküldenénk őket a második CPA fokozatba (II.10. ábra).

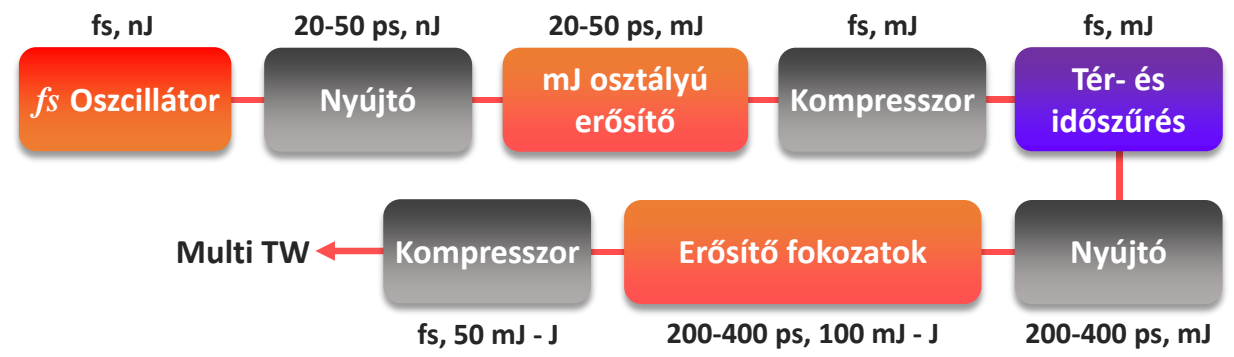

II.10. ábra DCPA rendszer elvi felépítése.

Az tér- és időszürésre nemlineáris effektusokat szokás alkalmazni, amelyek közül a leginkább elterjedt megoldás a keresztpolarizációs hullám (cross-polarized wave, XPW) keltése. Az XPW keltés egy 
harmadrendủ nemlineáris folyamat, és olyan anyagban hozható létre, amelynek $\chi^{(3)}$ harmadrendü nemlineáris szuszceptibilitása anizotróp. Az effektus során a beeső lineárisan polarizált impulzus a polarizációs irányára merőleges, szintén lineáris polarizációjú impulzust hoz létre (II.11. ábra). A keltett XPW impulzus intenzitása a beeső impulzus intenzitásának harmadik hatványával arányos. Ennek megfelelően a hatásfok csak az impulzus térben és időben legintenzívebb részei esetén lesz nagy, így a tér- és időbeli profil jelentősen kisimul, valamint az elö- és utóimpulzus kontraszt akár 4-5 nagyságrenddel is megnövelhetö.

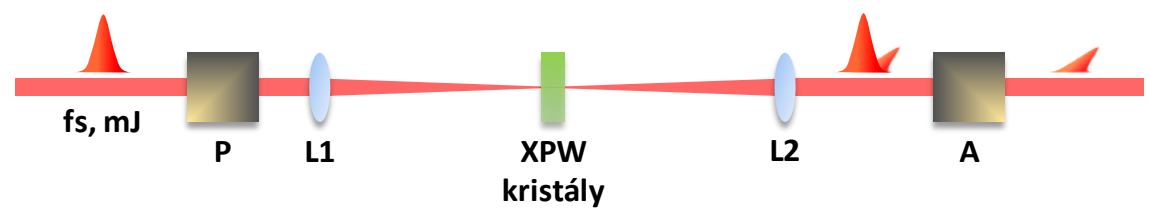

II.11. ábra XPW keltés sematikus képe. P és A polarizátort és analizátort, L1 és L2 akromatikus lencséket jelöl. Az eredeti impulzust az analizátor kioltja, amely eredményeként az elrendezést csak az XPW folyamat során keltett, időben és térben kitisztított impulzus hagyja el. Az XPW folyamat létrehozásához jellemzően $\mathrm{BaF}_{2}$ vagy $\mathrm{CaF}_{2}$ kristályt használnak.

Magas hatásfokot két-kristályos elrendezés segítségével értek el, amely révén az eredeti 10 ps-nál mért $10^{6}$ elöimpulzus-kontraszt $10^{10}$ értékre nőtt [96,97]. Fontos továbbá, hogy az XPW impulzus spektrumának szélessége a beeső impulzusénak $\sqrt{3}$-szorosa [97-99].

Az első CPA fokozat impulzusainak tér- és időbeli tulajdonságainak javítását követően azokat jellemzően egy diffrakciós rácsos elrendezésben több száz ps hosszúságúra nyújtják. Erre azért van szükség, mert az impulzusnyújtót követő számos további erősítő fokozatban a B-integrál értéke túlzottan megnövekedne a szükséges mennyiségü fázismoduláció létrehozásának hiányában. Az impulzusokat többpasszos elrendezések segítségével akár több $J$ energiára erősítik, majd végül a nyújtóval közel megegyező diszperzióval rendelkező diffrakciós rácsos kompresszorral összenyomják őket. A kompresszort az impulzusok nagy csúcsintenzitása miatt jellemzően vákuumkamrában helyezik el, elkerülve a levegőben kialakuló nemlineáris effektusokat, valamint a nagyméretü optikai rácsok károsodásait.

\section{II.2.5. Polarizáció-kódolt fázismodulált impulzuserősítés}

Napjainkban a néhányszor 10 TW-tól a több PW-ig terjedő csúcsteljesítménnyel rendelkező ultrarövid impulzusok elóállítására legelterjedtebb módon a Ti:Sa alapú lézerrendszerek teljesítenek szolgálatot. Bár az erősített impulzusok spektruma az erősítés során beszükül, illetve eltolódik a közeli infravörös irányában, ami az impulzusok hosszát jelentősen limitálja, a lézererősítés magas hatásfoka és megbízhatósága, valamint a pumpaimpulzusok tér- és időbeli profiljára vonatkozó enyhébb igények nagy előnyt jelentenek más architektúrákkal szemben. Emiatt jelen pillanatban is számos új Ti:Sa alapú rendszer épül vagy kerül installációra a kísérleti igények kielégítésére, amelyre jó példa, hogy az Extreme Light Infrastructure (ELI) [100] mindhárom pillérének PW osztályú ultrarövid impulzusú rendszerei, vagy az APOLLON projekt [11] keretében megvalósuló lézer is Ti:Sa alapúak lesznek. Több módszert kifejlesztettek már a spektrális limitációk enyhítésére, mint a DAZZLER (Fastlite) [66,101], etalonok [102], vagy spektrálisan szürő dielektrikum tükrök [103], amelyeket az erősítés során kell implementálni. Az említett metódusok akár együttes alkalmazásával 17-20 fs körüli impulzushossz érhető el. A közelmúltban egy új, polarizációs elven müködő eljárást javasoltak, amely segítségével az impulzusok erősítés előtti spektrális sávszélessége megtartható [104]. A metódus megértéséhez érdemes megemlíteni, hogy a Ti:Sa két polarizációs irányra vonatkozó erősítési hatáskeresztmetszetének értéke 
jelentősen eltérö (II.1. táblázat), mégpedig $\sigma_{\sigma} \approx 0,4 \cdot \sigma_{\pi}$ kapcsolat áll fenn közöttük. Ennek fényében az eljárás lényege, hogy a Ti:Sa alapú erősítőkben az optikai forgatási diszperzió (optical rotatory dispersion, ORD) felhasználásával a beeső impulzus spektrumának eredeti lineáris polarizációját megváltoztatjuk: a spektrális komponensek polarizációs vektorait úgy forgatjuk el, hogy a spektrum centrális részét, amely az erősítési spektrum közepén helyezkedik el, a $\sigma-$-, míg a spektrum széleit a $\pi$ tengelyhez állítjuk be (II.12. ábra). A felvázolt módszert polarizáció-kódolt erősítésnek nevezzük. Az erősítés során a beeső impulzus spektrumának centrális része kisebb, addig a spektrális szélek nagyobb erősítést érzékelnek, amely hatására az erősítés spektruma úgy hangolható, hogy a konvencionális erősítők esetében fellépő spektrális beszűkülés kompenzálható legyen. Az első, jobbra forgató kvarc kristállyal kódoljuk a spektrum polarizációs állapotait. A két félhullámlemez forgatásával állíthatjuk be, hogy az impulzus teljes spektruma a $\sigma$ - és $\pi$-tengelyek közé essen. Az erösítést követően a második, balra forgató kvarc kristály az elsőhöz képest ellentétes előjelű forgatási diszperziója révén dekódolja a spektrum polarizációs állapotait.

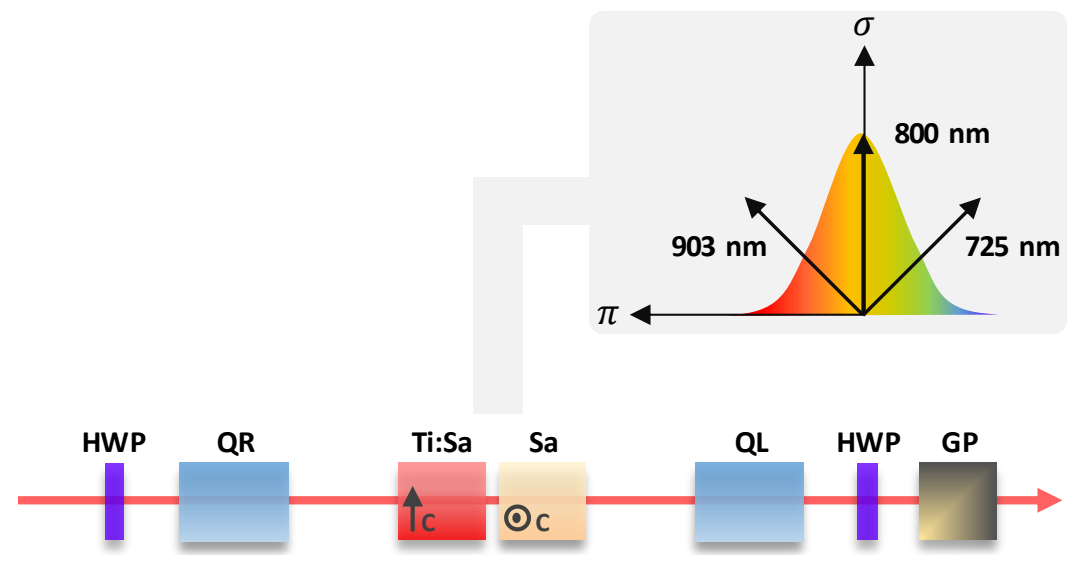

II.12. ábra Polarizáció-kódolt erősítés metódusának sematikus képe. HWP félhullámlemezt, QR és QL jobbra és balra forgató kvarc kristályokat, Sa zafír kristályt, GP pedig Glan-polarizátort jelöl. C-vel az optikai tengelyek irányát jelöltem a Ti:Sa és Sa kristályok esetén.

Mivel a Ti:Sa kristály kettőstörő, a két tengely menti impulzusterjedés között GD különbség lép fel. Ezt az időbeli késleltetést a két komponens között egy, a Ti:Sa kristállyal azonos vastagságú, de a Ti:Sa orientációjára merőleges optikai tengelyű zafír kristály segítségével lehet kompenzálni.

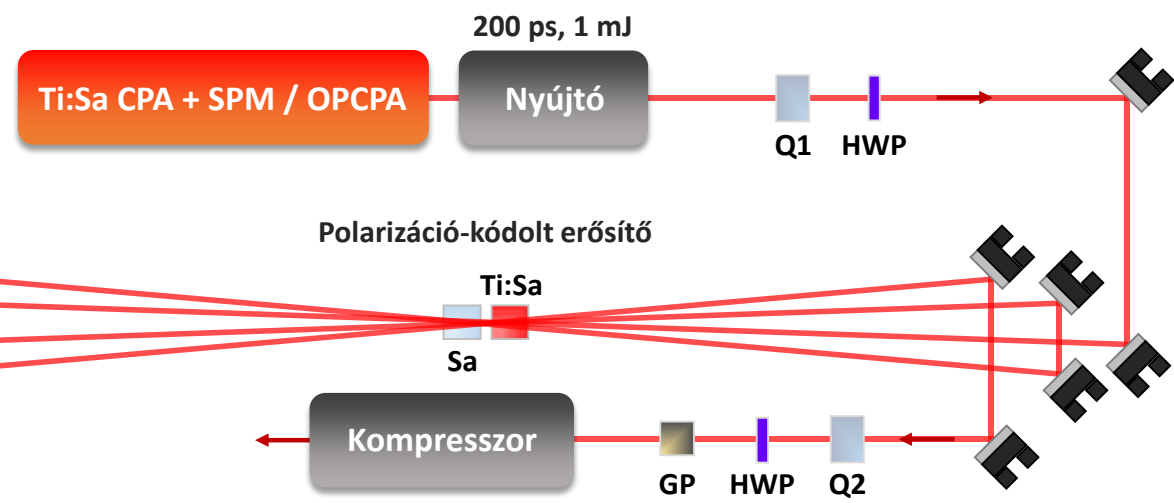

II.13. ábra PE-CPA rendszer elvi felépítése. Q1 és Q2 kvarc kristályokat, HWP akromatikus félhullámlemezeket, Sa zafír kristályt, illetve GP Glan-polarizátort jelöl.

A dekódolást követően egy polarizátoron való áthaladással a $\sigma$-polarizációjú komponens kioltásával ismét egy tisztán lineárisan poláros impulzust nyerünk. Ezért az így kapott elrendezést polarizáció- 
kódolt fázismodulált impulzuserösitésnek (polarization-encoded chirped pulse amplification, PE-CPA) nevezzük. Ennek sematikus felépítését egyetlen PE erősítő fokozattal a II.13. ábra szemlélteti. Az erősítés során a spektrális komponensek polarizációs állapota megváltozik, így azok nem dekódolhatóak vissza tökéletesen. Ez az effektus az erösítés értékével skálázódik, amely az optimális müködést a kis erősítésű, multipasszos geometriájú erősítőkre korlátozza. Ilyenek tipikusan a közép- és végerősítők a TW-PW osztályú rendszerekben. A magimpulzusokat a polarizáció-kódolt erősítés előtt ki kell nyújtani időben, majd az erősítést követően kompresszálni, a DCPA technikához hasonlóan. A kívánt impulzusenergia eléréséhez a PE erősítés több fokozatban való alkalmazása szükséges. A PE-CPA technikára vonatkozóan végzett szimulációs és kísérleti munka alapján a polarizáció-kódolt erősítés akár $200 \mathrm{~nm}$ spektrális félértékszélességü impulzusok spektrumát is képes megtartani az erősítést követően [104].

A megfelelően szélessávú magimpulzusok előállítása az erősítést megelőzően $(0,1 \mathrm{~mJ}-1 \mathrm{~mJ}$ energiával) önmagában is kihívást jelent. Ezt a hagyományos Ti:Sa alapú CPA rendszerek után például nemesgázzal feltöltött ún. üres magú optikai szálban (hollow-core fiber, HCF) önfázismoduláció (selfphase modulation, SPM) révén a kompresszált impulzus spektrumának jelentős kiszélesítésével lehet elérni [105-107]. Érdemes megemlíteni egy másik, napjainkban jelentősen kutatott módszert az erősített impulzusok utólagos időbeli összenyomására: az impulzusok spektrumának szilárdtestben való kiszélesítése, illetve fehérfény (kontinuum) keltése (white light generation, WLG), majd a diszperzió kompenzálása akár egyciklusos impulzusok előállítását is lehetővé teszi [108-110].Másik módszer lehet, ha a hagyományos CPA helyett OPCPA rendszert használunk, amelyben a megfelelően szélessávú fázisillesztés teljesülése esetén NOPA erősítők alkalmazásával kellően széles spektrum nyerhető a Ti:Sa erősítési spektrumának tartományában.

\section{II.2.6. Átlagteljesítmény felskálázása koronglézerek segítségével}

A nagy átlagteljesítményü lézersugárzás előállításához több koncepció jelent meg a lézermüködés geometriájára és az aktív közeg hütésére vonatkozóan, mint az ún. innoslab [111,112], vagy az optikai szállézerek és erősítők [113,114]. A leginkább alkalmazott megoldást az ún. korong architektúra (thin disk, $\boldsymbol{T D})$ jelentette, amely első kísérleti demonstrációjára 1994-ben került sor [115].

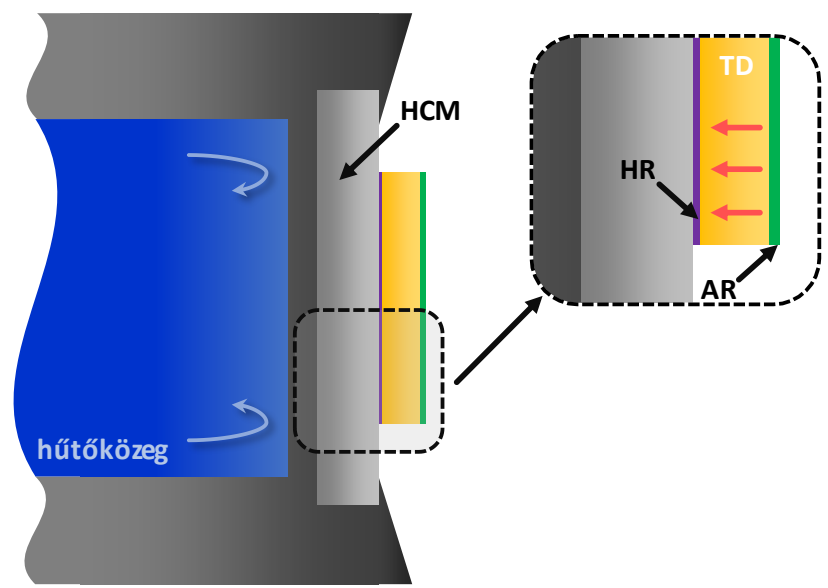

II.14. ábra Koronglézer fejegység sematikus képe. HCM jó hővezető képességü anyagot, HR nagyreflexiójú, AR antireflexiós rétegeket, TD pedig korong aktív közeget jelöl [41].

A koncepció lényege, hogy a hagyományos rúd típusú lézereknél alkalmazott, a nyalábirányra nézve transzverzális irányú hőkicsatolás helyett egy vékony korong geometriájú aktív közeget használunk. Ekkor a hőkicsatolás gyakorlatilag csak a nyalábbal azonos, longitudinális irányban megy végbe, amit 
úgy biztosítunk, hogy a korong alakú közeget egyik oldalával egy hőcserélőre rögzítjük (II.14. ábra). A hőcserélő korong felőli részén jellemzően valamilyen nagy hővezető képességü anyag található, például gyémánt, amely a korongban felhalmozódó hőt a lehető leghatékonyabban hivatott kicsatolni. A hőt végül egy áramoltatott hütőközeg, tipikusan víz vonja el a nagy hővezetésủ anyag felöl. Az aktív közeg hőcserélő felőli optikai felületét nagyreflexiójú (high-reflection, $\boldsymbol{H R}$ ) bevonattal ellátva mind az erősítendő, mind a pumpa hullámhosszára Ezáltal az erősítő közeg ún. aktív tükörként fog müködni, vagyis mindkét hullámhossztartományt visszaveri. Az elülső optikai felületet az imént említett mindkét hullámhossztartományra antireflexiós (anti-reflection, $\boldsymbol{A R}$ ) bevonattal szokás ellátni, hogy a müködés során fellépő reflexiós veszteségeket minimalizálják [41,116].

Az imént leírt eljárás rohamos fejlődését főként egy típusú lézerkristály, az Yb:YAG tette lehetővé. Ez a kvázi három energiaszintes rendszerrel rendelkező aktív közeg igen hosszú, $950 \mu$ s aktív szint élettartama, valamint alacsony kvantum defektusa miatt különösen alkalmas dióda lézerekkel történő közvetlen pumpálásra [117]. Továbbá, az alacsony frakcionális hődisszipációs tulajdonsága révén a hőterhelés a korong geometria segítségével jól kezelhető. Az Yb:YAG 940 és $970 \mathrm{~nm}$ körüli maximumokkal rendelkező abszorpciós spektruma jól egyezik a nagy átlagteljesítményt stabilan biztosító InGaAs diódák emissziós sávjával, amely nagy teljesítményü lézermüködést tesz lehetővé [117]. Fontos továbbá, hogy a YAG hordozó kristály relatíve magas hővezetési együtthatóval, valamint jó mechanikai tulajdonságokkal rendelkezik, amely a hőterhelés által eredményezett deformációkat jelentősen moderálja. Érdemes megjegyezni, hogy az elmúlt évtizedben a II.2.3. alfejezetben ismertetett OPCPA rendszerek rohamos fejlődése nem kis mértékben annak köszönhető, hogy a dióda pumpált Yb:YAG koronglézerek képesek 1 ps körüli, vagy akár szub-ps időbeli hosszúságú impulzusok előállítására 1030 nm hullámhossz körül. Számos OPCPA erősítő hatékony pumpálásához éppen ilyen lézerekre van szükség, amelyek ráadásul nagy ismétlési frekvenciával, és így nagy átlagteljesítménnyel is tudnak pumpaimpulzusokat biztosítani jellemzően egy frekvenciakétszerező modul után. Továbbá, egy nagy átlagteljesítményű koronglézer oszcillátorból kiindulva több fokozatú nemlineáris spektrális kiszélesítést és posztkompresszálást követően akár CEPstabil, néhány ciklusos impulzusok is elöállíthatóak [41].

A korong geometria jellemzője, hogy néhány száz $\mu \mathrm{m}$ vastagságú aktív közeget alkalmaznak. Bár az Yb:YAG tipikusan magasabb szinten adalékolható, mint a Ti:Sa, a pumpateljesítmény megfelelő szintű abszorbeálásához így is több tíz passzt kell kialakítani a pumpanyalábra vonatkozóan [116]. Ehhez bonyolult leképező tükörrendszert szokás megvalósítani, hogy a pumpanyaláb mérete és minősége az aktív közegben azonos legyen a passzok során [118]. Érdemes megemlíteni, hogy a koronglézerek pumpálásra használt dióda lézerek nyalábminősége jelentősen elmarad a Ti:Sa rendszerek esetén használt villanólámpás Nd:YAG vagy a DPSS pumpalézerekétől. Emiatt jellemzően optikai szálba csatolják a dióda lézer kimenetét, amely térszürést végez a nyalábon, majd számos leképező optika segítségével ráképezik azt az erősítő közegre. A femtoszekundumos koronglézer oszcillátorok müködése a hagyományos Ti:Sa oszcillátorokéhoz hasonló. Tipikusan a néhány $10 \mathrm{MHz}$ ismétlési frekvenciatartományban üzemelnek, közel 100 fs impulzushossz mellett [119,120].

A koronglézer oszcillátorok tipikusan $\mu \mathrm{J}$ nagyságrendủ impulzusenergiáját az ismétlési frekvencia csökkentése mellett korong erősítőkben szokás megnövelni. Ezt jellemzően regeneratív rezonátorokban végzik el, amelyekben több tíz passzt hoznak létre az erősítendő impulzusok számára [121,122]. A CPA architektúrát sikerrel alkalmazták az Yb:YAG alapú koronglézerek esetén is, amely révén energetikus, szub-ps impulzusokat állítottak elő [41,123]. Egy ilyen rendszerben mind a magimpulzusokat szolgáltató oszcillátor, mind az erősítő(k) korong geometriájúak. Az impulzusok időbeli nyújtását és 
összenyomását az ilyen rendszerekben is jellemzően diffrakciós rácsokon alapuló elrendezésekkel végzik el. A nagy csúcsteljesítményü impulzusok előállítását a CPA architektúrákban regeneratív típusú mellett multipasszos erősítőkben is szokás megvalósítani [124-126]. A hőterhelés megosztása miatt egy erősítőn belül akár több TD modul alkalmazása is előfordul [123,127]. 


\section{II.3. Vivő-burkoló fázis mérése és stabilizálása}

Az erősített femtoszekundumos impulzusok CEP-je alapvetően befolyásolja az extrém nemlineáris optikai folyamatok kimenetelét, így az attoszekundumos tudományban fellépő effektusokat, továbbá kritikus a frekvencia metrológiai alkalmazások szempontjából is. Ennek eredményeként az ultrarövid impulzusok CEP-jének detektálása és stabilizálása a lézeroszcillátorokkal és CPA rendszerekkel elérhető impulzusidő lerövidülésével egyre fontosabbá vált a 2000-es évek elején. Több kísérleti elrendezést is kifejlesztettek az elmúlt két évtizedben a CEP mérésére [128]. A CEP csúszásának, azaz az $f_{C E O}$ offszet frekvencia változásának megmérésére egy femtoszekundumos oszcillátor esetén elsőként egy nemlineáris keresztkorrelációs technikát alkalmaztak, amelyhez egy kellően nagy karhosszal rendelkező interferométert valósítottak meg [129].

\section{II.3.1. CEP-csúszás mérése: f-to-2f és 0-to-f interferometria}

A CEP csúszásának meghatározását elsőként módusszinkronizált oszcillátorok esetén végezték el. A napjainkban is leginkább használt módszer a következő elven alapul: spektrálisan és időben átfedetve ugyanazon optikai impulzussorozat különböző harmonikusait lebegési jelenséget hozhatunk létre, amely során a lebegési frekvencia megegyezik az $f_{C E O}$ értékkel. Leggyakrabban az alap és a másodharmonikus által létrehozott lebegési frekvenciát mérik, ezt a módszert f-to-2f interferometriának szokás nevezni [130-132]. Ebben az esetben az alapharmonikus spektrumának el kell érnie az oktáv szélességet, mivel a másodharmonikus keltést (second harmonic generation, SHG) követően annak alacsony frekvenciájú (vörös oldali hullámhosszak) spektrális széle lebeg össze az alapharmonikus magas frekvenciájú (kék oldali hullámhosszak) spektrális szélével (II.15. ábra, alapharmonikus és SHG frekvenciaspektrumának összelebegése).

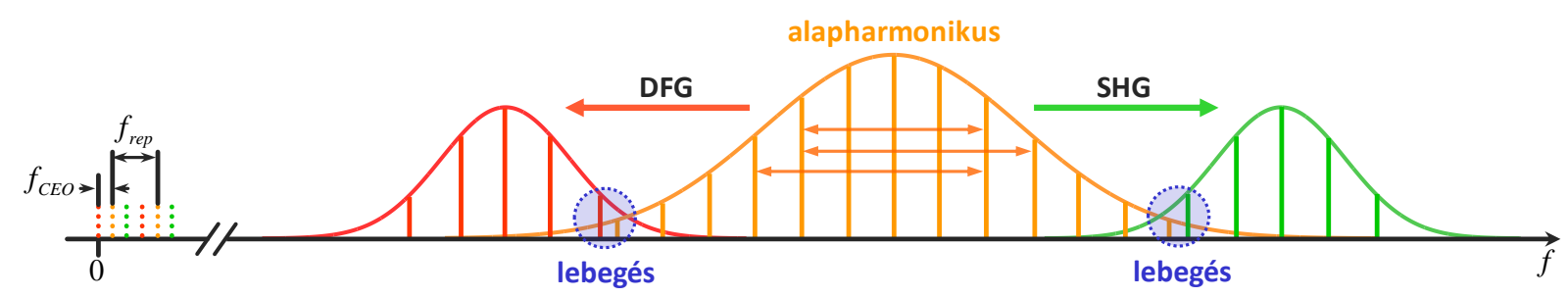

II.15. ábra $\mathrm{Az}$ f-to-2f és 0-to-f interferometria alapelve [133]. A lézer spektrumából (alapharmonikus) nemlineáris kristályban SHG vagy DFG folyamat révén az eredetivel részben átfedő addicionális spektrumot hozunk létre.

Belátható, hogy az $f_{1}$ alapharmonikus és az $f_{2}$ másodharmonikus közötti lebegés frekvenciájára a

$$
2 f_{1}-f_{2}=\left(2 f_{\text {CEO }}+2 m \cdot f_{\text {rep }}\right)-\left(f_{\text {CEO }}+2 m \cdot f_{\text {rep }}\right)=f_{\text {CEO }}
$$

összefüggés nyerhető, amely éppen az $f_{C E O}$ értéket adja meg. Ez az offszet frekvencia pedig egy fotodióda és egy spektrum analizátor segítségével jól detektálható. Alternatív megoldásként az alapharmonikus két spektrális széle közötti különbségi frekvencia keltést (difference frequency generation, DFG) alkalmazzák, amely során a DFG és az alapharmonikus jel közötti lebegési frekvenciát detektálják [130,133,134]. Ezt a technikát szokás 0-to-f interferometriának nevezni (II.13. ábra, alapharmonikus és DFG frekvenciaspektrumának összelebegése). A lézer spektrumának két széle közötti DFG keltéssel az f-to-2f interferométer esetén (II.54) egyenlettel felvázolt információt nyerjük, csupán azt az alapharmonikus alacsony frekvenciájú széle és a DFG spektrum közötti lebegéssel. Érdemes azonban megemlíteni, hogy a DFG keltés egy speciális tulajdonsággal is rendelkezik. A 
spektrum magas és alacsony frekvenciájú komponensei közötti frekvenciakeverésre vonatkozóan fennáll az

$$
f_{D F G}=\left(f_{C E O}+n_{\text {high }} f_{\text {rep }}\right)-\left(f_{C E O}+n_{\text {low }} f_{\text {low }}\right)=\left(n_{\text {high }}-n_{\text {low }}\right) f_{\text {rep }}
$$

összefüggés, amelyből kiolvasható, hogy a DFG jel független az $f_{C E O}$ értékétől. Ez azt jelenti, hogy a DFG impulzusok CEP-je eredendően stabil. Felhasználva a DFG által eredményezett passzív CEPstabilitást eredendően fázisstabil OPCPA rendszereket valósítottak meg [135-137].

A CPA illetve OPCPA rendszerek kimenetén kapható erősített impulzusok CEP-csúszásának mérését az f-to-2f technika kis módosításával szokás elvégezni. Mivel a CPA erősítők kimenetén az oszcillátor ismétlési frekvenciájánál jóval alacsonyabb, jellemzően $10 \mathrm{~Hz}$ és $10 \mathrm{kHz}$ közötti frekvenciájú impulzus sorozat csatolható ki, az alap- és a másodharmonikus által létrehozott lebegési frekvencia helyett a két tér közötti spektrális interferenciát tudjuk mérni egy spektrométer segítségével. Az f-to-2f interferométer bemenetén az impulzusok sávszélessége szinte kivétel nélkül bőven oktáv alatti, így ebben az esetben is szükséges a spektrum WLG révén történő kiszélesítése. Az elrendezés meghajtásához szükséges impulzusenergia jellemzően néhány $10 \mu \mathrm{J}$ nagyságrendủ, emiatt zafír, YAG, vagy valamilyen fluorid kristály alkalmazása célszerü a WLG folyamathoz. A spektrális interferenciához szükséges csoportkésleltetés-különbséget a két spektrálisan a széleiknél átfedő, és időben egymást a koherencia időn belül követő impulzus között a másodharmonikus keltő kristályban lévő diszperzió különbség hozza létre $[138,139]$. A módszer segítségével a jelenlegi detektorokkal $10 \mathrm{kHz}$ ismétlési frekvenciáig minden impulzus fáziscsúszása mérhető, azaz egylövéses üzemmódban tudunk detektálni.

\section{II.3.2. Alrendszerek fáziscsúszásának mérése: spektrálisan bontott interferometria}

Az erősített impulzusok CEP-csúszásának mérése és stabilizálása a CPA rendszeren való áthaladást követően az alkalmazások előtt kiemelt fontosságú. Lézerfejlesztési szempontból azonban számos esetben fontossá válik, hogy az egyes alrendszerek milyen hozzájárulással rendelkeznek a CEP csúszásához, valamint zajához. Az f-to-2f interferométerek érzékenysége nem elegendő ahhoz, hogy alrendszerek hatását egyértelmúen meg lehessen határozni. Ezen felül a nemlineáris folyamatokon alapuló detektálás az impulzus csúcsintenzitására, és így annak időbeli hosszára erős korlátozásokat vezet be. Ez a limitáció mind az oszcillátorok, mind az erősített impulzusok esetén az impulzuskompresszió minőségére nézve jelentős.

A nemlineáris effektusokat is alkalmazó detektálási sémákhoz képest számos elönyös tulajdonsággal rendelkezik az ún. spektrálisan bontott interferometria (spectrally resolved interferometry, SRI), amely egy teljesen lineáris optikai módszer. Ennél a technikánál ugyanis az intenzitás a detektor érzékenységétől eltekintve nem jelent korlátozást. Fontos továbbá, hogy a módszer csupán egy mérhető sávszélességgel rendelkező fényforrást igényel, amely lehet fehérfény-kontinuum, egy oszcillátor impulzussorozata, vagy egy erősített impulzus is [140]. Szélessávú impulzusokat tekintve az SRI alapelve a következő: két impulzus spektrális fázisa közötti különbséget méri. Ezáltal az egyik impulzus spektrális fázistolásának ismertnek kell lennie, amely mindig egy ismert referencia impulzus felhasználásával kerül biztosításra. Az másik impulzus valamilyen optikai közegen halad keresztül, amely megváltoztatja annak spektrális fázisát. Ezt a fázisváltozást a két impulzus spektrális interferenciájának mérésével kaphatjuk meg [141-147]. Tipikusan kétnyalábos interferométerek, például Mach-Zehnder vagy Michelson-típusú elrendezések használatosak a mérés elvégzéséhez. Egy 
tipikus kísérleti elrendezést a II.16. ábra szemléltet. A szélessávú fényforrás lehet szélessávú impulzus, vagy akár egy fehérfény lámpa is. Érdemes kiemelni, hogy a fényforrás sávszélességére vonatkozó követelmény alkalmazásfüggő, de az f-to-2f és 0-to-f interferométereknél jellemző oktáv szélességre nincs szükség. Jelen esetben legyen a fényforrás egy femtoszekundumos oszcillátor, amelyből származó impulzusból az első nyalábosztó (BS1) két replikát hoz létre. Az egyik replika a referencia karon halad át, amelyben egy lineáris eltoló egység mozgatásával tudjuk beállítani az interferométer egyenlő karhosszához közeli késleltetést. A másik replika a tárgykarban, az abban elhelyezett diszperzív közegen halad keresztül. A tárgy- és a referencia impulzusokat a második nyalábosztó (BS2) segítségével egyesítjük, és egy vonalas spektrométer (SM) belépő résére küldjük.

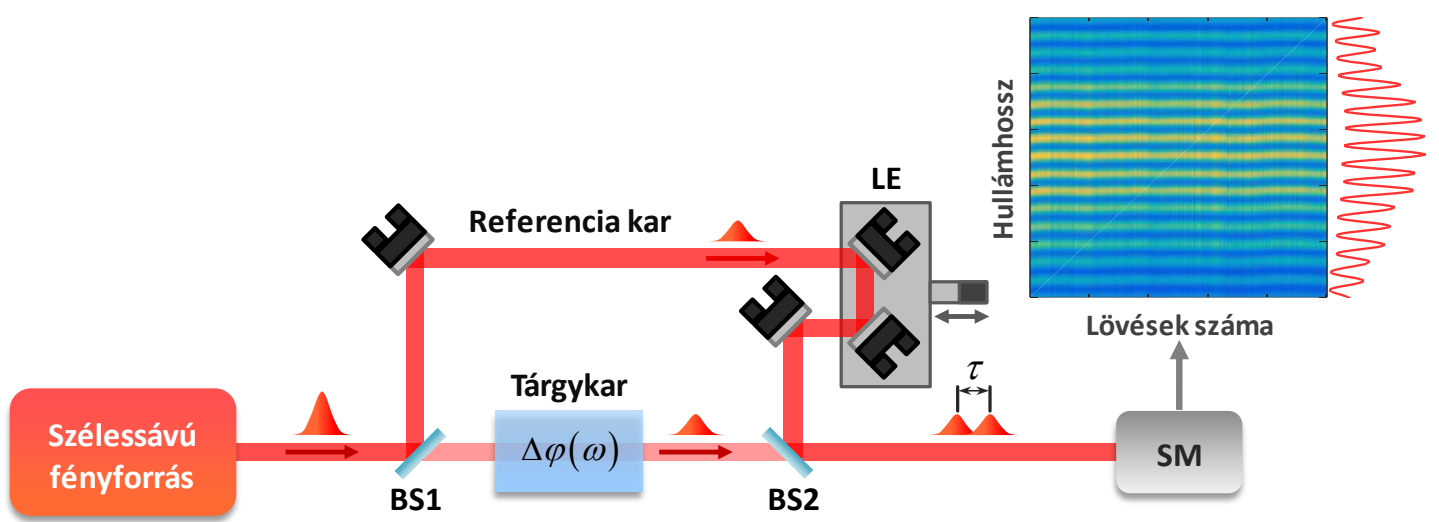

II.16. ábra SRI mérési módszerhez használt tipikus kísérleti elrendezés Mach-Zehnder típusú interferométerrel. BS nyalábosztókat, LE lineáris eltolót, SM pedig vonalas spektrométert jelöl.

A referencia karban terjedő impulzus spektrális fázisának alakja a tárgykartól teljesen független, valamint tekintettel arra, hogy csak levegőben való terjedés jön létre, a spektrális fázis jó feltételezéssel változatlan marad. Ezáltal a mérések során a referencia karban terjedő impulzus valódi referenciaként funkcionál, s így az interferométer végén mért fáziskülönbség teljes egészében a tárgykarban elhelyezett minta spektrális fázistolását fogja adni. Jelölje ekkor $I_{R}(\omega)$ a referencia, illetve $I_{S}(\omega)$ a tárgy impulzus spektrális intenzitását, amelyekkel felírható a spektrométer által detektált interferencia jel intenzitása az

$$
S(\omega)=\left|\tilde{E}_{S}(\omega)\right|^{2}+\left|\tilde{E}_{R}(\omega)\right|^{2}+f(\omega) e^{i \omega \tau}+\text { c.c. }
$$

összefüggés, ahol $f(\omega)=\tilde{E}_{S}(\omega) \cdot \tilde{E}_{R}^{*}(\omega)$. Az utolsó két tagot felírhatjuk az $2|f(\omega)| \cos \left[\varphi_{R}(\omega)-\right.$ $\left.\varphi_{S}(\omega)+\omega \tau\right]$ alakban, amely gyors modulációt eredményez a frekvencia függvényében. Ezt a modulációt nevezzük spektrális interferenciának. A moduláció átlagos periódusa fordítottan arányos a tárgy és a referencia impulzusok között beállított $\tau$ időbeli késleltetéssel. Amennyiben a kísérletileg megvalósított elrendezés a II.16. ábrán vizualizálthoz hasonlóan a referencia karban csak levegőben való impulzusterjedést valósít meg, a mért interferencia jel fázisára érvényes, hogy

$$
\arg [f(\omega)]=\varphi_{S}(\omega)-\varphi_{R}(\omega)=\Delta \varphi(\omega),
$$

azaz csak a minta által okozott $\Delta \varphi(\omega)$ spektrális fázisváltozást detektáljuk. A (II.12) kifejezéshez hasonló módon a mért $\Delta \varphi(\omega)$ fázisváltozást Taylor-sorba fejtve, a CEP változását a tárgykarban a

$$
\Delta \varphi_{C E}=\Delta \varphi\left(\omega_{0}\right)-\Delta G D \cdot \omega_{0}
$$

összefüggés adja. 
A mért interferometrikus jelből a spektrális fázistolás értéke a frekvencia függvényében kinyerhető. Ehhez munkám során a leginkább alkalmazott, gyors lefutású és a zajok kiszürésében leginkább effektívebb módszert, az ún. Fourier-transzformációs kiértékelést használtam. A kiértékelésnél fogva a teljes metódust Fourier-transzformációs spektrális interferometriának (Fourier-transform spectral interferometry, FTSI) nevezik. Tekintsünk ekkor egy 800 nm hullámhossz körül centrált, két szélessávú impulzus által létrehozott spektrális interferenciát, amelyhez egy Mach-Zehnder interferométer tárgykarjában $500 \mathrm{fs}^{2}$ GDD-vel és $300 \mathrm{fs}^{3}$ TOD-val rendelkező diszperzív közeget helyezünk el. Az interferométer két karja közötti késleltetést állítsuk 500 fs-ra, hogy jól kivehető spektrális modulációt kapjunk (II.17. ábra, (a) rész). Az interferogram által hordozott fázis információ kinyeréséhez végezzük el az inverz Fourier-transzformációt az $S(\omega)$ spektrumon, amelyre a

$$
\begin{aligned}
\mathcal{F}^{-1}\{S(\omega)\}= & E_{R}^{*}(-t) \otimes E_{R}(t)+E_{S}^{*}(-t) \otimes E_{S}(t)+ \\
& +f(t-\tau)+f(-t-\tau)^{*}
\end{aligned}
$$

kifejezést kapjuk, ahol $f(t)=E_{R}^{*}(-t) \otimes E_{S}(t)$ a két tér közötti korrelációs tag. A két korrelációs tag a közül az $f(t-\tau)$ a $t=\tau$ időpontban, addig az $f(-t-\tau)^{*}$ pedig $t=-\tau$ pontban centrált (II.17. ábra, (b) rész). Pontos kiértékeléshez szükséges feltétel, hogy a $\tau$ késleltetés értékét úgy válasszuk meg, hogy az egyes tagok ne fedjenek át az időtartományban, amely könnyen teljesíthető a referencia karban lévő lineáris eltoló pozíciójának finomhangolásával.
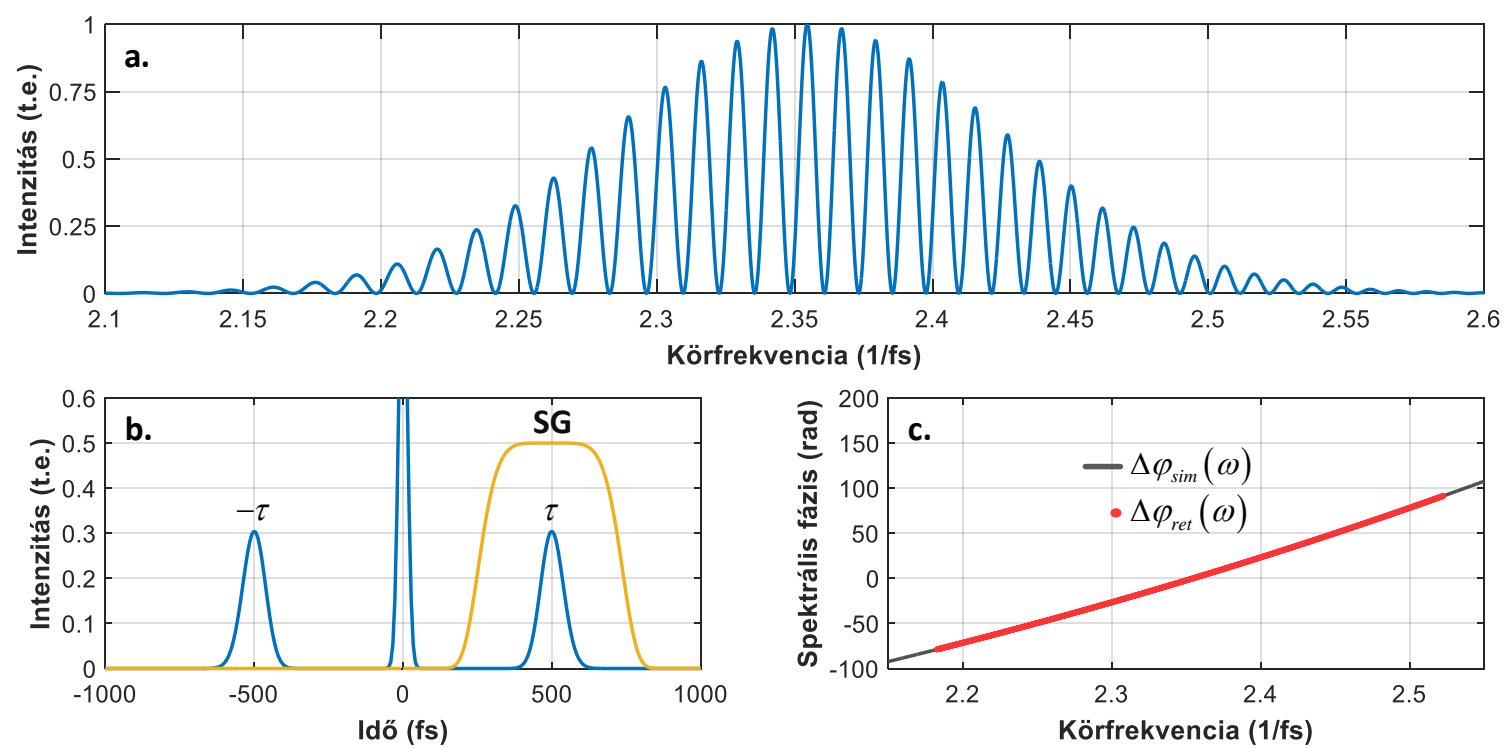

II.17. ábra Szimulált interferogram 500 fs GD, $500 \mathrm{fs}^{2}$ GDD és $300 \mathrm{fs}^{3}$ TOD fázisderiváltakkal rendelkező közegen való SRI mérésére vonatkozóan (a). Inverz Fourier-transzformációval kapott jelalak az időtartományban, illetve Super-Gauss ablakfüggvény (SG, maximális intenzitás átskálázva a jobb láthatóság miatt) a $\tau$ késleltetésnél lévő jelre (b). A megszürt időbeli jelet visszatranszformálva a frekvenciatartományba, a komplex argumentum megadja a fáziskülönbség értékét a frekvencia függvényében, ahol szürkével a szimulált fázisfüggvény, míg pirossal a kiértékelésből kinyert fázisfüggvény látható (c).

Ezt követően az időtartományban megfelelően megválasztott időablakkal kiszürjük az egyik, az ábrán jelöltek szerint a $t=\tau$ körül centrált korrelációs tagot. A megszürt jelet vissza Fourier-transzformálva a frekvenciatartományba az $f(\omega)$ frekvenciafüggő korrelációs tagot kapjuk, amely komplex argumentuma a $\Delta \varphi(\omega)$ spektrális fáziskülönbséget adja meg [146]. A spektrális fázist $2 \pi$ ugrásokkal, fésűfog alakú görbeként kapjuk meg, amelyből a hasznos fázis ún. unwrap-peléssel, azaz a $2 \pi$ ugrások eliminálásával nyerhető (II.17. ábra, (c) rész). A kiértékelt spektrális fázisra a $d \omega=\omega-\omega_{0}$ 
függvényében polinom illesztéssel meghatározható az egyes fázisderiváltak értéke, amelyekből a CEP változása is kiszámolható.

\section{II.3.3. Spektrálisan bontott interferometria soksugaras interferométerrel}

A CEP csúszásának értéke oszcillátorok esetén lineáris interferometriai módszerrel is hozzáférhető: spektrálisan, vagy spektrálisan és térben bontott interferometria felhasználásával akár $1 \mathrm{~nm}$ alatti spektrális sávszélesség mellett is meghatározható a CEP impulzusról impulzusra bekövetkező csúszása [148,149]. A módszer lényege, hogy egy rezonáns soksugaras interferométerben az oszcillátor impulzussorozatának több egymást követő impulzusa között hozunk létre spektrális interferenciát, amely esetén a mintázat pozíciójában kódolva van a CEP csúszásának értéke. A rezonáns interferométer karhossza közel meg kell, hogy egyezzen a lézeroszcillátor rezonátor hosszával. Az egyszerüsített mérési elrendezést a II.18. ábra mutatja be.

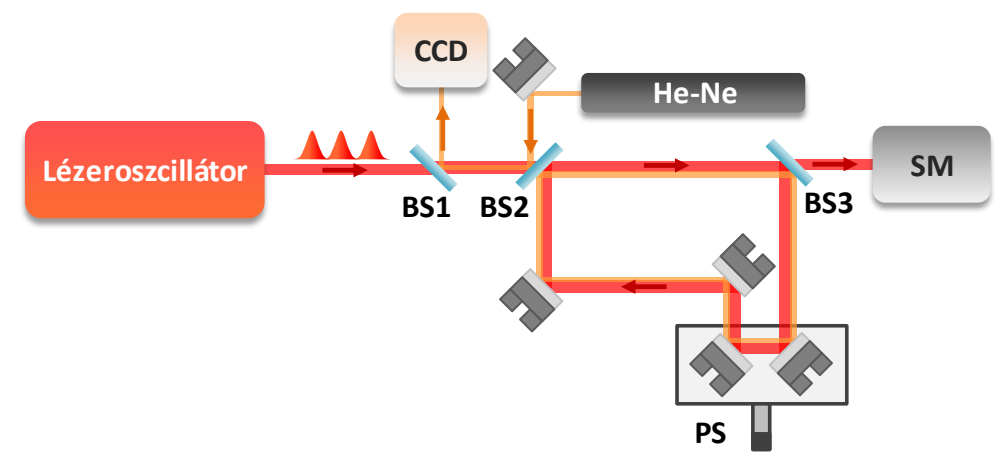

II.18. ábra Sematikus optikai elrendezés az impulzussorozatok CEP-csúszásának lineáris interferometrikus mérésére. BS1, BS2 és BS3 nyalábosztók, PS piezo eltoló egység, SM spektrométer.

Mivel a lézeroszcillátorok jellemzően a néhányszor $10 \mathrm{MHz}$ ismétlési frekvencián müködnek, a méréshez szükséges interferométer karhossza a néhány méter nagyságrendjébe esik. Ez hőmérsékleti és mechanikai eredetü stabilitási problémákat eredményez. A problémát egy segédlézer és egy CCD-n vizsgált térbeli interferencia alapján piezo-eltolóra való visszacsatolás alapján, az interferométer karhosszának úthosszstabilizálása által lehet feloldani (II.18. ábra, He-Ne lézer nyalábútja). A mérési módszer nagy előnye, hogy jóval kisebb intenzitást igényel, mint a nemlineáris optikán alapuló f-to-2f interferometria, valamint keskeny spektrális sávszélesség mellett is elvégezhető. A megvalósított prototípus esetén a mért CEP-csúszás alapzaja a legpontosabb mérés esetén 100 mrad körüli értékü volt. A metódust akár ps hosszúságú oszcillátor impulzusok CEP csúszásának mérésére is fel lehet használni, amely más módszerrel nem végezhető el [150].

\section{II.3.4. Abszolút CEP mérése: stereo-ATI}

Számos extrém nemlineáris optikai folyamat, továbbá ultragyors molekuláris effektusok vizsgálata során nem elegendő a CEP csúszásának mérése, hanem a CEP abszolút értékének, azaz a vivőhullám burkoló alatti tényleges pozíciójának ismerete is elengedhetetlenné válik. A CEP abszolút értékének mérését emiatt közvetlenül a céltárgy előtt kell elvégezni, amely a mérő berendezésre vonatkozóan is korlátozásokat vezet be. Az eddig ismertetett mérési módszerek az abszolút CEP meghatározására nem alkalmasak. Ha azonban megvizsgáljuk az atomos gázok közül például a xenon küszöb feletti ionizációs (above-threshold ionization, ATI) spektrumát, azt találjuk, hogy erősen függ az ionizáló lézerimpulzus elektromos terének alakjától, azaz a tér fázisától. Ekkor rögzítve az ATI spektrumot az impulzus 
polarizációjával párhuzamosan egyszerre két irányból, aszimmetria nyerhető, amely a CEP mérését lehetővé teszi [151,152]. Az ilyen mérési eljárásra alkalmas berendezés a II.19. ábrán figyelhető meg.

a.

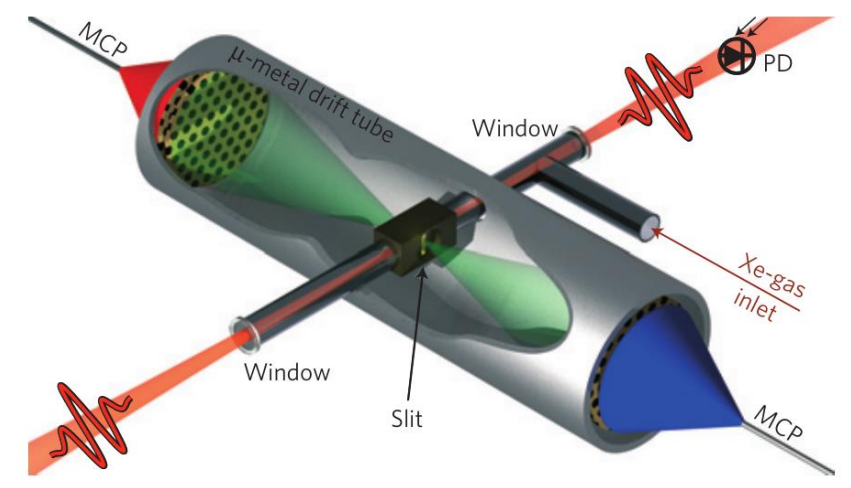

b.

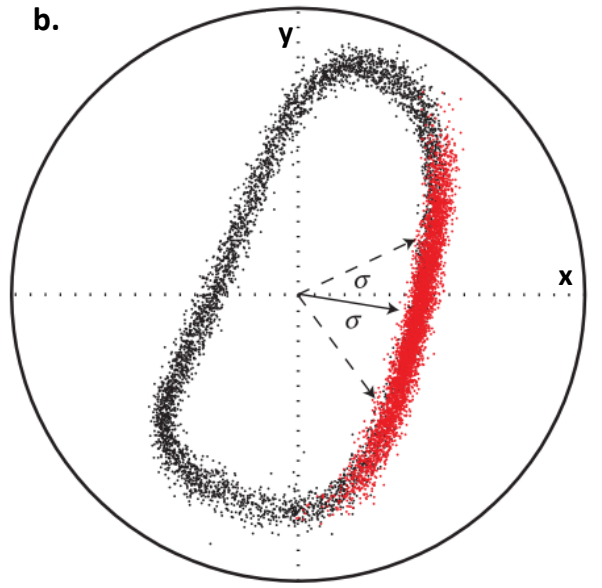

II.19. ábra Stereo-ATI fázismérő berendezés [152] sematikus képe (a). A két egymással szemben álló MCP detektor egy nagyvákuumra szívott fémcsőben helyezkedik el. A belső részbe juttatott xenon atomok a lézertér fókusza körül ionizálódnak, és az elektronokat a két MCP detektálja a drift csövekben való terjedést követően. Window vákuumablakokat, slit rést, $\mathrm{PD}$ fotodiódát, MCP detektorokat, Xe-gas inlet xenon gáz bemenetet jelöl. Mérésből [152] származó 4500 impulzus fázisa (b). A fekete pontok nem stabilizált, míg piros pontok pedig CEP-stabilizált lövéseket jelölnek, ahol a stabilizált lövések egy elöre beállított CEP érték körül adott $\sigma$ standard deviációval oszlanak el.

A mérés pontosságát alapvetően meghatározza a mérni kívánt impulzus hossza: az ATI spektrum CEPfüggése az impulzushossz csökkenésével emelkedik, azaz a gyakorlatban a néhány-ciklusos lézerimpulzusok mérése kivitelezhető megfelelő pontossággal. A beérkező lineárisan polarizált néhány ciklusos impulzus polarizációjával párhuzamosan, egymással szemben helyeznek el két repülési idő spektrométert (time of flight, TOF). Ekkor a berendezés belsejébe juttatott xenon atomok ionizációjából származó elektronok spektrumát a két TOF spektrométer végében található MCP (micro channel plate) detektorok rögzítik. A mérés minden lövés eredményét rögzíti, azaz a berendezés egylövéses módban müködik akár $100 \mathrm{kHz}$ ismétlési frekvenciájú lézer fázisstabilitásának mérését is lehetővé téve. A fotoelektron spektrumok aszimmetriáját az ún. normalizált fázis szimmetria paraméterrel jellemzik, amit a bal és jobb oldal irányában, adott elektron-energia tartományban detektált elektronszám határoz meg. Amennyiben a két fázis aszimmetria paramétert egymás függvényeként ábrázoljuk, egy ellipszis-szerü sokaságot kapunk (II.19. ábra, b rész), amely minden lövés CEP értékét tartalmazza. A görbe origótól mért sugara a mért impulzus hosszával arányos, addig az adott pontot az origóval összekötő sugár xtengellyel bezárt szöge a CEP értékét adja. A mérés elvégzéséhez tipikusan néhányszor $10 \mu \mathrm{J}$ impulzusenergia szükséges, amely alapján kiszámolható, hogy közelítőleg $10^{14} \mathrm{~W} / \mathrm{cm}^{2}$ csúcsintenzitás szükséges a fókuszban a megfelelő ATI spektrum létrehozásához. Érdemes megemlíteni, hogy a mérés az ionizált gáz alacsony nyomása miatt gyakorlatilag változatlanul hagyja a mért impulzusokat, így azok időbeli (és spektrális), valamint térbeli tulajdonságai sem degradálódnak [151-154].

\section{II.3.5. Oszcillátorok és erősítők CEP-stabilizálása}

Történeti szempontból érthető módon a módusszinkronizált femtoszekundumos oszcillátorok, konkrétan a Ti:Sa alapú fényforrások esetén sikerült először elérni, hogy a CEP impulzusról impulzusra bekövetkező változása ne véletlenszerüen jöjjön létre. Azaz nagy fontosságú, hogy a CEP változását valamilyen fix értékre rögzítsük, vagyis stabilizáljuk. Ezt a II.3.1. alfejezetben említett detektálási 
módszerek kifejlesztése tette lehetővé, azonban eddig nem merült fel, hogy a stabilizálási eljáráshoz a detektálásnak adott jel-zaj viszony feletti lebegési jelet kell szolgáltatnia. Tudományos eredményeim megértése szempontjából elengedhetetlennek tartom, hogy mind az oszcillátorok, mind pedig az erősítők után elérhető CEP-stabilizálás főbb módszereit és az elérhető fázisstabilitást áttekintsük [128].

Az Ti:Sa oszcillátorok esetén a 2000-es évek elején az ún. feed-back, vagy visszacsatolásos módszer fejlesztése kapott számottevő figyelmet, elsőként az f-to-2f detektálással [155]. Fontos mérföldkövet jelentett, amikor is egy teljesen kollineáris 0-to-f interferométer felhasználásával rendkívül nagy, $55 \mathrm{~dB}$ jel-zaj viszonnyal sikerült lebegési jelet generálni [133]. A CEP stabilizálását az oszcillátor pumpalézerének nyalábútjába helyezett akuszto-optikai modulátorra épülö szervo kör végezte. A monolitikus kialakításnak köszönhetően a széles frekvenciatartományon $(\mathrm{mHz}-35 \mathrm{MHz})$ mért fáziszaj RMS értéke mindössze 100 mrad lett, amit egy független szervo körön lévő f-to-2f interferométer mért. Ez a fáziszaj érték egy impulzus burkolója és vivőhulláma között mért 44 as időbeli bizonytalanságnak (jitter) feleltethető meg.

Öt évvel a 100 mrad fáziszajú müködés demonstrálását követően, egy új stabilizációs koncepció került kifejlesztésre, ami a feed-forward nevet kapta [156]. Az alapvető különbség a visszacsatolásos módszerhez képest, hogy a feed-forward technika esetén nincs szükség az oszcillátor müködésének megváltoztatására, amely magában hordozza a lézermüködés destabilizálásának lehetőségét. Egy addicionális akuszto-optikai frekvencia eltoló (acousto-optic frequency shifter, AOFS) egység segítségével ugyanis a Doppler-eltolódás felhasználásával az impulzus egész frekvencia spektruma eltolható a kívánt értékkel, ami éppen a CEP változásának korrekcióját fogja jelenteni. A lebegési jelet ebben az esetben egy f-to- $2 \mathrm{f}$ interferométer méri a korrekcióval egyidejüleg, amely révén a CEP stabilizálása valós időben történik. Érdemes megemlíteni, hogy az AOFS-ben történő akusztikus hullám terjedése a korrekció frekvenciaválaszának sávszélességét limitálja. A módszerben rejlő potenciált mutatja, hogy a CEP stabilitását sikerült $45 \mathrm{mrad}$ értékre javítani, amely már csupán 20 as időbeli bizonytalanságot jelentett [128].

A CEP-stabilizálás Ti:Sa oszcillátorok esetén elérhető eddigi maximumát a feed-back és feedforward módszerek kombinálása hozta el, amit kettős stabilizálásnak szokás nevezni [157]. A kettős stabilizálás során egy a pumpalézer teljesítményét szabályozó visszacsatoló kört, valamint egy feedforward kört az AOFS egységgel együtt is müködtettek. A kettős stabilizálással 20 mrad CEP-zajt, azaz 8 as időbeli bizonytalanságot értek el, amely az eddig demonstrált legalacsonyabb érték [128]. Az oszcillátorok fázisstabilizálásának további fejlesztése több szempontból is kérdéses. Egyrészt a detektált lebegés jel-zaj viszonyának jelentős javulása szükséges ahhoz, hogy egyáltalán a stabilizálás minőségének emelkedését mérni tudjuk. Másrészt, felmerül a kérdés, hogy mikor érünk el fundamentális fizikai korlátot, amely már kvantumos jelenségek által meghatározott, át nem léphető határt képez a javulásban [158].

Az oszcillátorok esetén alkalmazott sok lövésre átlagoló detektáláshoz képest az erősített impulzusok CEP-csúszásának mérését egylövéses detektálással is el lehet végezni, mivel azok energiája tipikusan $1 \mathrm{~mJ}$ körüli, vagy jóval ezen energia érték feletti. Az oktáv szélességü spektrumhoz valamilyen kristályban létrehozott WLG folyamat révén jutunk. Az adott szilárdtest roncsolási küszöbe által korlátozott impulzusenergia miatt jellemzően $100 \mathrm{~nJ}$ körüli energia konvertálható csak át szuperkontinuum formájában [128]. Az f-to-2f interferométer müködéséhez szükséges SHG folyamat szintén limitálja az elérhető jel-zaj viszonyt, amely az erősített impulzusok esetén egy spektrométer által felbontott spektrális interferencia láthatóságában fog megmutatkozni. Egy CPA rendszer CEPstabilizálása a kimeneti impulzusból leválasztott, kis energiájú rész CEP-csúszásának méréséből kapott 
jel visszacsatolásával érhető el. Ez a visszacsatolás érintheti az oszcillátort, vagy az erősítő fokozat(ok) pumpalézerét, illetve a kompresszort is [139]. A leggyorsabb korrekciós eljárást az erősítőkben használt AOPDF szervo körbe integrálása jelentette, amellyel 98 mrad RMS CEP-zajt értek el az erősítő teljes $10 \mathrm{kHz}$ ismétlési frekvenciáján [159]. 


\section{Tudományos célkitűzések}

\section{III.1. Motivációs háttér}

Jelen disszertációban összefoglalt munkám elsődleges célja a jelenleg elérhető Ti:Sa alapú erősítési technológia továbbfejlesztése. Három főbb aspektust emelnék ki, amelyek a Ti:Sa alapú erősítő rendszerek felhasználhatóságának javítását eredményezhetik. Az első ilyen terület az erősítők CEPstabilitásának lézerparaméterektől való függésének pontos ismerete. Egy CPA rendszer CEP-zajának leghatékonyabb mérséklését az erősítő fokozatok saját fáziszajának ismeretében, azok körültekintő megtervezésével és a működési paraméterek megfelelő megválasztásával lehet elérni, amely továbbá elősegíti a CEP-stabilizáló módszerek működését is.

A második főbb terület az erősítők átlagteljesítményének jelentős megnövelése. Ehhez az erősítő fokozatokban a nagy pumpateljesítmény miatt fellépő hőterhelést kell kezelni, amely súlyos nyalábdegradációhoz, végső soron akár az optikák roncsolásához is vezethet. Jelenleg a 100 TW osztályú erősítők akár $10 \mathrm{~Hz}$ ismétlési frekvencián, addig a PW osztályú erősítő rendszerek 1-3 Hz frekvencián képesek múködni [160]. Speciális pumpaenergia disztribúciós technikával akár $10 \mathrm{~Hz}$ ismétlési frekvencia is elérhető 2 PW csúcsteljesítmény mellett, amely az ELI-ALPS Kutatóközpont építés alatt álló Nagyintenzitású Lézerének (High Field Laser, $H F-2 P W$ ) első generációs kimenetét fogja jelenteni (III.1. ábra). Több alkalmazás szempontjából előnyös, ha az ismétlési frekvencia ennél nagyobb is lehet. Amennyiben ugyanis az ismétlési frekvenciát meg tudjuk növelni egy 100 TW - PW osztályú lézerrendszer esetén néhányszor $10 \mathrm{~Hz}$, vagy akár $100 \mathrm{~Hz}-\mathrm{re}$, az adott kísérlet során a méréshez szükséges idő jelentősen lerövidül, valamint egy mérés alatt az impulzusok paramétereinek változásai minimalizálódnak. Fontos továbbá, hogy az ipari alkalmazásokhoz rendkívül előnyös tulajdonság lehet egy lézerrendszer esetén a nagy csúcs- és átlagteljesítmény egyidejü megléte.

A harmadik terület, amelyen a Ti:Sa erősítő technológia további javulást érhet el, az erősítés után elérhető spektrális sávszélesség növelése. A fázismodulált impulzusok erősítése során fellépő spektrális beszükülés jelentősen korlátozza a CPA rendszerek kimenetén kapható sávszélességet, és így az elérhető legrövidebb impulzusidőt, amely a Ti:Sa lézerek hütési problémák melletti legnagyobb Achilles-sarka. Számos módszert javasoltak már az erősítési sávszélesség megnövelésére [66,103,161-164], s így a bemenő impulzusok sávszélességének erősítés során való megtartására, ezek azonban továbbra is $17 \mathrm{fs}$ körüli értékre tudták csak leszorítani az elérhető legrövidebb impulzusidő értékét.

Disszertációm során a fentiekben felsorolt fejlesztési területek közül az első kettőre, illetve ezek lehetséges megoldásaira fogok koncentrálni. Kiemelném azonban, hogy a Ti:Sa erősítőket érintő munkám az új erősítő koncepciók kutatásán túl az ELI-ALPS Nagyintenzitású Lézerének második, nagy ismétlési frekvenciájú és nagy energiájú karjának megvalósításához szükséges új technikák kifejlesztésére irányult. A HF-100 rendszer a HF-2PW lézerrel közös frontenddel rendelkezik, azonban attól eltérő koncepción fog alapulni (III.1. ábra). A megcélzott impulzushossz 10 fs értékü, amely konvencionális Ti:Sa erősítőkkel nem, ugyanakkor OPCPA erősítés révén elérhető. A szóban forgó nagy energiájú impulzusok ultranagy sávszélességü erősítésének OPCPA alapú megvalósítására nem volt még példa, valamint a szükséges ps-os pumpalézer technológia sem áll jelenleg rendelkezésre. A PECPA koncepció [104] alkalmazása Ti:Sa erősítő közeggel kellő sávszélességet biztosíthat az extrém rövid impulzusok eléréséhez. Emellett legalább 0,5 J kompresszált impulzusenergia elérése a cél $100 \mathrm{~Hz}$ ismétlési frekvencián, amely jelentős hőterhelést jelent a végerősítő Ti:Sa kristályára vonatkozóan. A 
kimeneti impulzusok továbbá CEP-stabilizáltak kell legyenek, amely újabb kihívást jelent az erősítésre vonatkozóan.

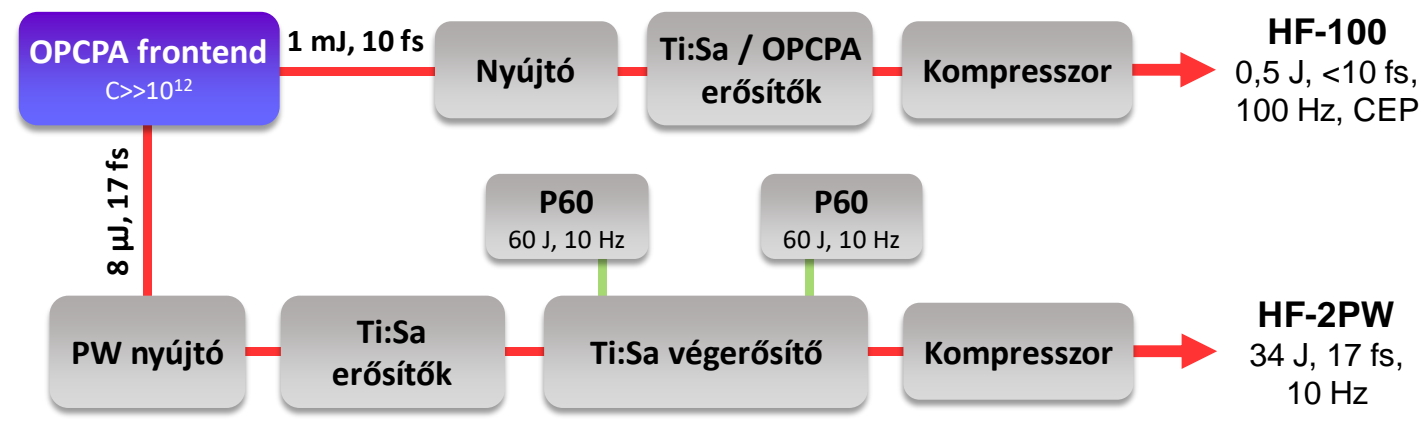

III.1. ábra ELI-ALPS HF-2PW és HF-100 lézerrendszerének sematikus képe. P60 a HF-2PW kar végerősítőjét meghajtó pumpalézereket jelöli [14].

Összefoglalva, a HF-100 csatorna megcélzott impulzusparamétereinek eléréséhez mind a Ti:Sa, mind pedig az OPCPA alapú erősítési metódus esetén jelentős fejlesztésekre van szükség. Tekintettel a Ti:Sa alapú erősítők meghajtásához szükséges pumpalézerek elérhetőségére, valamint jóval alacsonyabb költségeire, az energiában való egyszerübb felskálázási lehetőségekre, valamint a lézererősítés nagyobb hatásfokára, célszerü ezen kristályon alapuló új koncepciók kifejlesztésében gondolkodni. 


\section{III.2. Disszertáció célkitűzései}

A disszertációm alapjául szolgáló tudományos munkám célkitüzéseit a következő pontokban foglalom össze:

C1. Vizsgálatokat végzek a vízhűtéses Ti:Sa erősítők kristályában kialakuló CEP-csúszásra. Kísérletileg megvizsgálom a CEP impulzusról impulzusra vett stabilitását befolyásoló tényezőket a lézererősítés során. Meghatározom továbbá, hogy az erősítő kristály hűtésének instabilitásai milyen hatással lehetnek az erősített impulzusok CEP-jére.

C2.a. Megvizsgálom egy kriogenikus hűtésü Ti:Sa erősítőben fellépő spektrális fáziszaj értékét befolyásoló hatásokat. Továbbá meghatározom, hogy a vákuum rendszerek, illetve a kriogenikus hủtőfej mekkora fáziszaj járulékot eredményeznek az erősített impulzusok esetén. Megállapítom, hogy az erősítő müködésének különböző szakaszaiban a mechanikai eredetü zajkomponensek milyen forrásokból származnak.

C2.b. Meghatározom a termikus és mechanikai eredetü CEP-zaj értékét a Ti:Sa erősítő müködése során. Megvizsgálom az erősített impulzusok CEP-zajának statisztikai eloszlását az ismétlési frekvencia függvényében.

C3.a. Megvizsgálom az ultranagy csúcsteljesítményü TD Ti:Sa erősítő fokozatok megvalósításának lehetőségeit. Ehhez szimulációkat végzek a konvencionális és TD geometriájú erősítőkben kialakuló hőmérséklet-eloszlásokra.

C3.b. Kísérletileg megvizsgálom az erősítést egy vízhütéses Ti:Sa TD lézerfej segítségével. Megmérem a korongerősítő kristályában pumpálás mellett kialakuló hőmérséklet-változást, valamint az egyensúlyi állapotban kialakuló hőmérsékletprofilt. Továbbá megvizsgálom az Ti:Sa kristályban pumpálás esetén kialakult termikus hatások által eredményezett hullámfront-torzulás mértékét.

C4.a. Numerikus modellt építek a HF-100 lézerrendszer Ti:Sa végerősítőjének TD módszerrel való megvalósíthatóságának vizsgálatára. Megállapítom a vízhűtés hatását a kristálybéli hőmérsékleteloszlásra egy- és kétcsatornás elrendezések segítségével.

C4.b. Megvizsgálom a kétoldali hütésű Ti:Sa korongerősítők további felskálázási lehetőségeit. Nagyobb kimeneti energiájú erősítők termikus müködését fogom megvizsgálni különböző ismétlési frekvenciákon, egy- és kétkristályos lézerfejekben. 


\section{IV. Új tudományos eredmények}

A nagyintenzitású lézerekkel folytatott munkám 2013-ban indult, amikor is az SZTE TeWaTi Femtoszekundumos Lézer Laboratóriumában kísérletileg vizsgálni kezdtem az ultrarövid impulzusok fázisváltozásait Ti:Sa erősítőkben. Miután megismerkedtem a TeWaTi Ti:Sa alapú CPA rendszerének müködésével, felhasználva az MSc képzés alatt megszerzett tapasztalataimat a spektrális interferometriával kapcsolatban, két vízhütéses, multipasszos Ti:Sa erősítő elrendezést vizsgáltam meg a vivő-burkoló fázis stabilitására vonatkozóan.

Miután 2014 szeptemberében csatlakoztam az ELI-ALPS Kutatóközpont Lézer Infrastruktúra Osztályának Nagyintenzitású Lézer Csoportjához, figyelmem az ultranagy intenzitású erősítő rendszerek felé is irányult. Modell számításokat kezdtem végezni a 100 TW-tól egészen a néhány PW csúcsteljesítményü impulzusok előállítására alkalmas Ti:Sa alapú végerősítő fokozatok hőterhelésére vonatkozóan. Mind stacionárius, mind pedig időfüggő, numerikus szimulációkon dolgoztam, amelyek a Ti:Sa koronglézeres architektúrájú alkalmazását célozták meg.

A vízhűtéses erősítők mellett a nagy átlagteljesítményü CPA rendszerekben kriogenikus hűtést alkalmaznak a Ti:Sa kristályok hőterhelésének kompenzálására, amely az elrendezés fázis stabilitását több okból is potenciálisan leronthatja. Tekintettel arra, hogy az erősített ultrarövid impulzusok egyik fő alkalmazása a disszertáció írásakor (és valószínüleg még a közeli jövőben is) a másodlagos források, például izolált attoszekundumos impulzusok létrehozása magasharmonikus sugárzásból, az impulzusok spektrális fázisának stabilitása kiemelt fontosságú. Miután 2015 második felében a TeWaTi laborban elérhetővé vált egy Ti:Sa kristály hűtésére alkalmas kriogenikus hűtőegység, a vízhűtéses mérésekhez hasonló multipasszos erősítő elrendezést kezdtem kísérletileg vizsgálni az erősített impulzusok spektrális fázisának stabilitására vonatkozóan. A kriogenikus hütéshez szükséges vákuum rendszerek, valamint a hütőfej mechanikai rezgéseinek hatására külön figyelmet fordítottam.

A koronglézer geometriájú Ti:Sa erősítés potenciáljának demonstrálására 2015 őszén a Berlinben található Max-Born-Institut nagyintenzitású lézerének felhasználására nyílt lehetőség. A LaserLab Access program és az ELI-ALPS segítségével 2016 márciusáig összesen hét hetet töltöttem az intézetben, ahol jelentősen hozzájárultam az első koronglézer architektúrájú Ti:Sa erősítő megvalósításához és müködésének demonstrációjához. A nagyintenzitású lézer végerősítőjének magés pumpaimpulzusait felhasználva kutatótársaimmal felépítettünk egy aktív tükrös elrendezésü korongerősítőt. Miután karakterizáltuk az erősítést, méréseket végeztünk az erősítő kristályban kialakult hőmérséklet térben bontott profiljára vonatkozóan, valamint megmértük a nyalábfront torzulás értékét teljes hőterhelés alatt egy segédlézer felhasználásával.

Új tudományos eredményeim közül először a vízhütéses Ti:Sa impulzuserősítők fázisstabilitásával fogok foglalkozni, részletesen tárgyalva a kísérleti tapasztalatokat. A második részben egy kriogenikus hütésű Ti:Sa erősítő fázis- és mechanikai stabilitásmérése során született eredményeimet fogom ismertetni. A 100 TW osztályú lézerrendszerekben leginkább alkalmazott Ti:Sa végerősítő fokozatok továbbfejlesztésével kapcsolatos eredményeimről a harmadik és negyedik részben számolok be. A harmadik részben egy korong típusú Ti:Sa végerősítő kísérleti demonstrációja során született eredményeket mutatom be. Végül, az utolsó szakaszban a Ti:Sa korongerősítők termikus viselkedésével kapcsolatos numerikus modellezés eredményeiről fogok beszámolni. 


\section{IV.1. Vízhütéses Ti:Sa erősítők fázisstabilitása}

Az optikai rácsokon alapuló impulzusnyújtó és kompresszor egységek esetén kísérletileg már kimutatták, hogy ezen alrendszerek mechanikai rezgései egyértelmüen hozzájárulnak a teljes rendszer CEP-stabilitásának romlásához [165]. Az optikai parametrikus erősítés folyamatát már szintén megvizsgálták lineáris interferometriai módszer segítségével [166], ahol szignifikáns CEP-zaj növekedést tapasztaltak az erősítés folyamatának hatására, továbbá a pumpaimpulzusok időzítésének hatásait is meghatározták az erősített és az idler impulzusok CEP-jére vonatkozóan [167]. Az egyes alrendszerek CEP-stabilitásának vizsgálata ezzel ellentétben mindeddig nem terjedt ki a Ti:Sa alapú erősítő fokozatokra. Egy teljes CPA rendszer fázisstabilitását alapvetően befolyásolja, hogy az egyes alrendszerek milyen módon járulnak hozzá a stabilitás leromlásához. A CEP stabilizálásának módszereit és határait a II.3.5. alfejezetben már ismertettem. Fontos megemlíteni, hogy a stabilizálás hatékonyságát jelentősen növelni tudjuk, ha az egyes alrendszerek passzív módon is stabil fázist eredményeznek. Ebben az alfejezetben a CEP fluktuációinak szisztematikus vizsgálatát fogom bemutatni a lézerparaméterek változtatásának függvényében egy vízhütéses, többpasszos Ti:Sa erősítő esetében.

\section{IV.1.1. Kísérleti módszer és elrendezés}

Egy többpasszos Ti:Sa erősítő CEP-stabilitásának meghatározásához kielégítő, ha az erősített impulzusok spektrális fázisának változását mérjük az eredeti, nem erősített és fázisában érintetlenül hagyott impulzusokéhoz képest. Mindezt az SRI módszer felhasználásával tehetjük meg, ugyanis ezen metódus csak a tárgy és a referencia impulzus közötti fáziskülönbséget méri [140]. Történetesen, ha a belépő impulzusból egy nyalábosztó segítségével egy replikát generálunk, amely levegőben fog terjedni, annak spektrális fázisa, és így CEP-je is gyakorlatilag változatlan marad a megfelelő környezeti tényezők biztosítása mellett. Ennek megfelelően az így keletkezett replika tökéletes referencia lesz a mérés számára. Mindezt a gyakorlatban úgy tudjuk megvalósítani, hogy egy Mach-Zehnder típusú kétnyalábos interferométert véve, a tárgykarban építjük fel a többátmenetes Ti:Sa erősítőt, addig a referencia karban pedig a tárgykarban létrejövő terjedéssel közel azonos mértékű időbeli késleltetést valósítunk meg.

A méréseket a Szegedi Tudományegyetem Természettudományi és Informatikai Karának Optikai és Kvantumelektronikai Tanszékén található TeWaTi Femtoszekundumos Lézerlaboratóriumában végeztem el. A méréshez szükséges előerősített magimpulzusokat a TeWaTi-ban található Ti:Sa alapú CPA rendszer frontendje szolgáltatta. A rendszer fényforrása egy egyedi építésủ Ti:Sa oszcillátor volt, amely 60 nm félértékszélességü, megközelítőleg 20 fs hosszúságú impulzusokat biztosított a kimenetén $72 \mathrm{MHz}$ ismétlési frekvenciával (IV.1.1. ábra).

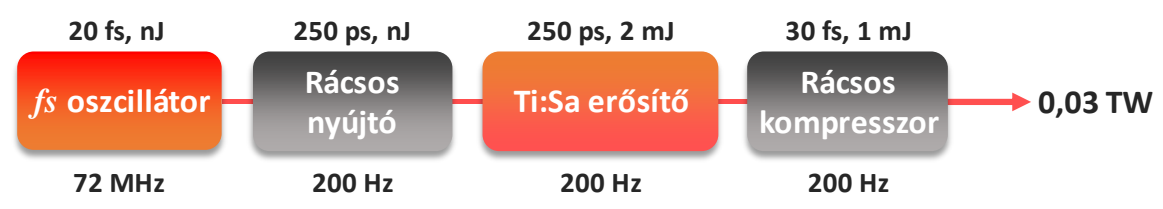

IV.1.1. ábra TeWaTi lézerrendszerének frontendje a felújítás előtt.

Az oszcillátor impulzusait egy diffrakciós rácsos impulzusnyújtó 250 ps hosszúságúra nyújtotta, majd egy Pockels-cellán alapuló elrendezés az impulzusok ismétlési frekvenciáját változtatható módon lecsökkentette. Ezt követően a nyújtott oszcillátor impulzusok egy tízpasszos Ti:Sa előerősítőben $2 \mathrm{~mJ}$ energiára erősödtek az eredeti 2 nJ értékről. Az erősítő ismétlési frekvenciája $200 \mathrm{~Hz}-\mathrm{re}$ lett beállítva, amit a Ti:Sa kristályban kialakuló termikus lencse effektus korlátozott. A rendszer végén egy rácsos 
impulzus kompresszor az erősített impulzusokat 30 fs körüli hosszra nyomta össze $1 \mathrm{~mJ}$ kimeneti energiával.

A mérések elvégzéséhez egy aszimmetrikus osztású Mach-Zehnder interferométert (Mach-Zehnder interferometer, MZI) építettem fel. A tárgykarban egy kompakt, hárompasszos Ti:Sa erősítőt valósítottam meg, amelyben 10-es erösítési faktort terveztem elérni. Ennek fényében az interferométer bemenetén egy 90\%:10\% osztású nyalábosztót (IV.1.1. ábra, BS1) helyeztem el. Így a beeső intenzitás 90\%-a a referencia karba, addig 10\%-a pedig a tárgykarba lett beküldve. Ezáltal biztosítani tudtam, hogy az MZI kimenetén közel azonos intenzitású impulzusokat tudjak egyesíteni, amelyhez egy 50\%:50\% osztású nyalábosztót (IV.1.1. ábra, BS2) használtam fel. A teljes mérési elrendezést a IV.1.2. ábra szemlélteti.

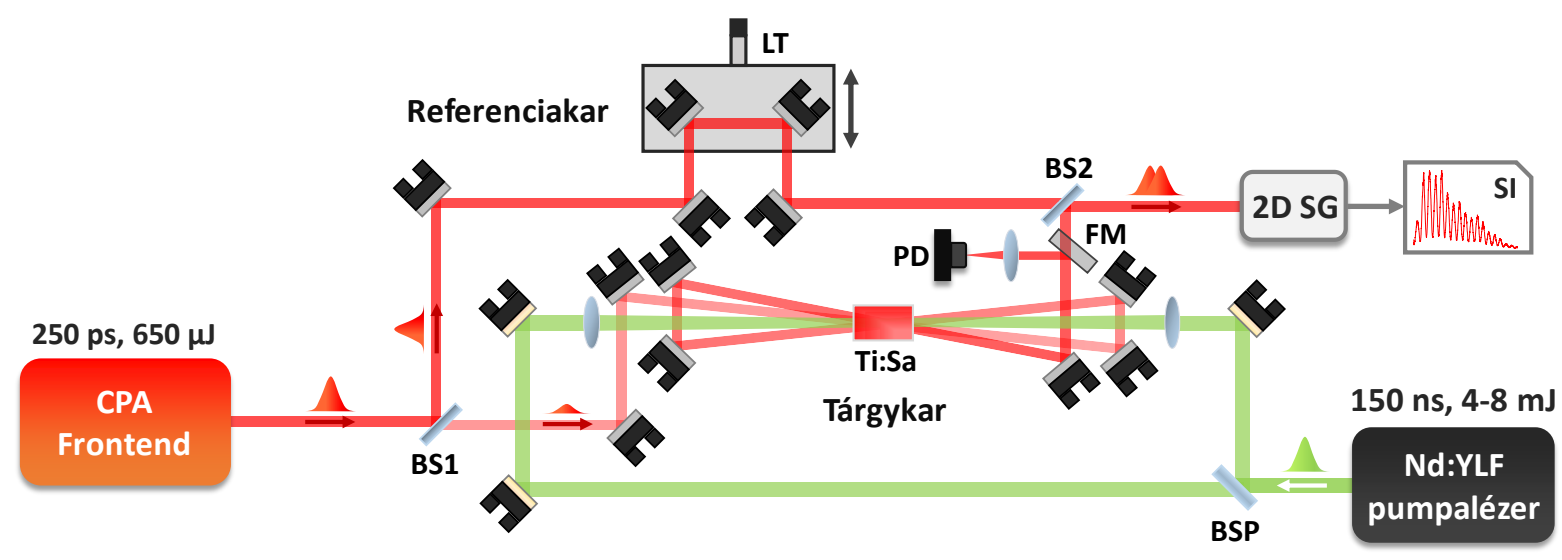

IV.1.2. ábra Mérési elrendezés a CEP stabilitásának vizsgálatához. BS1 és BS2 nyalábosztókat, LT lineáris eltolót, FM csapótükröt, PD fotodiódát, 2D SG leképező spektrográfot és SI spektrális interferenciát jelöl.

A frontend $2 \mathrm{~mJ}$ kimeneti energiájából a mérések nagy részében $650 \mu \mathrm{J}$ került becsatolásra az MZI bementére, amelyből így $65 \mu \mathrm{J}$ a tárgykarba jutott. A referencia karban egy lineáris eltoló segítségével hangolható módon tudtam állítani a két kar közötti időbeli késleltetést. A hárompasszos erősítőt két oldalról optikailag pumpáltam egy Photonics Industries DM32-527 típusú Nd:YLF DPSS pumpalézer segítségével, amely 150 ns FHWM hosszúságú, hangolható energiájú impulzusokat biztosított $527 \mathrm{~nm}$ hullámhosszon. A pumpalézer $0.2 \%$ RMS energiastabilitású impulzusokat generált elegendő energiával, hogy az erősítőt telítésbe vigyem. Technikai megvalósítás szempontjából fontos megjegyeznem, hogy az említett pumpalézer hajtotta meg a fentebb leírt előerősítő fokozatot is. Mivel a pumpaimpulzusok időzítése a CPA rendszer részét képező előerősítő magimpulzusaihoz volt beállítva, a minta erősítő meghajtását a pumpaimpulzusok jelentős időbeli késleltetésével kellett megoldani. Az előerősítő 10 átmenetes geometriája miatt (6,9 ns időbeli késés passzonként) mintegy $70 \mathrm{~ns}$ időbeli késleltetést hoztam létre a pumpaimpulzusok esetén 20,7 m levegőben való terjedés segítségével, amit a IV.1.2. ábrán a jobb átláthatóság érdekében nem tüntettem fel. Az erősítőbe belépő pumpa- és a magimpulzusok energiáját külön tudtam változtatni, amely az erősítő lézerparaméterektől függő fázisstabilitásának vizsgálatához elengedhetetlen volt. Az interferométer kimenetén kicsatolt impulzusokat egy $0,1 \mathrm{~nm}$ spektrális felbontással rendelkező leképező spektrográf (CE Optics, CEO-2D-800) bemenetére irányítottam. A spektrálisan és térben bontott interferenciát a térbeli tengely mentén kiátlagolva, spektrálisan bontott interferenciát rögzítettem. A megfelelően sürü, jól kiértékelhető interferogramokat a referencia kar egyenlő karhossztól való néhány tíz $\mu$ m-rel történő elhangolása biztosította. A mért interferogramok kiértékelésére a II.3.2. alfejezetben ismertetett Fourier-transzformációs módszert alkalmaztam, amely kellően alacsony kiértékelési zajt, és gyorsaságot biztosított. A teljes mérési 
elrendezés bedobozolásra és letakarásra került, hogy a légmozgás által okozott háttérzajt lecsökkentsem. Fontos továbbá, hogy a mérő rendszert tudományos célokra optimalizált, nagy szilárdságú és stabilitású optikai asztalon építettem fel, illetve megfelelően merev optomechanikákat alkalmaztam, tovább növelve a mérö rendszer passzív stabilitását.

Az általam felhasznált Ti:Sa kristály egy merőleges vágású, téglatest alakú, 8 × 8 × 14 mm méretű (14 mm az optikai minőségű felületek közötti távolság, vagyis a kristály hasznos hossza) darab volt, amely mindkét optikai felülete AR bevonatot kapott $532 \mathrm{~nm}$-re és $800 \mathrm{~nm}$ körüli hullámhossztartományra. Az erősítő közeg mért abszorpciós tényezője $2.31 / \mathrm{cm}$ értékü volt $527 \mathrm{~nm}$ hullámhosszon, amely alapján egy pumpaimpulzus egyszeri átmenetével az energia 96\%-a abszorbeálódik a kristályban. Így a hatékony erősítéshez elegendő volt a kristályban egyszeri átmenetet kialakítani a pumpaimpulzusokra vonatkozóan. A Ti:Sa kristályt réz foglalatban helyeztem el, amelyben a kristály közvetlenül hütővízzel érintkezett az optikai felületeire merőleges felületek mentén. Normál körülmények között a kristályt $16^{\circ} \mathrm{C}$-ra hütöttem le egy a CPA rendszertől függetlenül üzemeltetett hütőberendezés segítségével.

A kísérletek későbbi szakasza folyamán a TeWaTi laboratórium lézerrendszere jelentős fejlesztésen esett át (IV.1.3. ábra). A korábbi, egyedi építésű fényforrást egy Femtolasers Rainbow típusú, szintén Ti:Sa alapú lézeroszcillátor váltotta fel. Az új fényforrás már 7 fs hosszúságú, ultranagy spektrális szélességü impulzusokat generált $74 \mathrm{MHz}$ ismétlési frekvencián. Az impulzusok nyújtása a korábbi rácsos nyújtó helyett egy F5 üvegrúd segítségével lett megvalósítva, amely eredményeként az impulzusok időbeli hossza 30 ps körüli értéket vett fel.

\begin{tabular}{|c|c|c|c|c|c|}
\hline $7 \mathrm{fs}, \mathrm{nJ}$ & 30 ps, nJ & 30 ps, $\mu$ & & $30 \mathrm{ps}, 2 \mathrm{~mJ}$ & $25 \mathrm{fs}, 1,3 \mathrm{~mJ}$ \\
\hline fs oszcillátor & $\begin{array}{l}\text { Üvegtömb } \\
\text { nyújtó }\end{array}$ & $\begin{array}{c}\text { Ti:Sa erősítő } \\
5 \text { passz }\end{array}$ & $\begin{array}{l}\text { DAZZLER } \\
\text { + Pockels }\end{array}$ & $\begin{array}{c}\text { Ti:Sa erősítő } \\
5 \text { passz }\end{array}$ & $\begin{array}{c}\text { Rácsos } \\
\text { kompresszor }\end{array}$ \\
\hline $74 \mathrm{MHz}$ & $74 \mathrm{MHz}$ & $74 \mathrm{MHz}$ & $200 \mathrm{~Hz}$ & $200 \mathrm{~Hz}$ & $200 \mathrm{~Hz}$ \\
\hline
\end{tabular}

IV.1.3. ábra TeWaTi CPA lézerrendszerének frontendje a felújítás után.

A nyújtott impulzusok a teljes oszcillátor ismétlési frekvencián 5 passzban lettek erősítve a korábbival majdnem megegyező architektúrájú előerősítőben, amit követően áthaladtak a Pockels-cellán és egy DAZZLER-en. Az utóbbi eszköz a spektrális fázis különböző rendjeinek hangolására, valamint a spektrális amplitúdó modulációjával a spektrális beszükülés csökkentésére volt használva. Az impulzusok ezt követően újabb 5 passzban tovább erősödtek a korábban is elért $2 \mathrm{~mJ}$ energiáig. Végül az erösített impulzusok egy transzmissziós elvü, rácsos impulzuskompresszorban kerültek összenyomásra közel 25 fs időbeli hosszra $1,3 \mathrm{~mJ}$ impulzusenergia mellett. A későbbiekben felújított CPA rendszerként fogok hivatkozni a fejlesztéseken átesett rendszerre.

\section{IV.1.2. Vízhűtés és a pumpaimpulzusok hatásai}

Méréseim során elsőként a Ti:Sa kristály hűtésének be- és kikapcsolt, vagyis a kristálytartó egységben a hütővíz áramlásának beindításával és megszüntetésével elért állapotokban mérhető CEPváltozást vizsgáltam meg. Ahhoz, hogy a hủtés meglétének hatását a lehető legjobban ki tudjam mutatni, az erősítő kristályt a rendelkezésre álló legnagyobb ismétlési frekvencián és legnagyobb energiával, vagyis $200 \mathrm{~Hz}$-en $8 \mathrm{~mJ}$ energiájú impulzusokkal pumpáltam. Ebben az esetben ugyanis a pumpaimpulzusokból az erősítő közegben disszipált hő a legnagyobb értékủ, és így a hűtővíz áramlásának leállítása a kristály pumpált térfogatában számottevő hőmérséklet-növekedést eredményez. A Ti:Sa törésmutatójának hőmérsékletfüggése által ezt a mérés során CEP elcsúszásaként fogjuk detektálni. A mag- és a pumpaimpulzusok kristályon belüli térbeli átfedésének optimalizálását követően 
13-szoros erősítést értem el a harmadik passz után. A vízhütés kikapcsolása az erősítésre is hatással volt, azonban ez föként az erősített impulzusok energiastabilitásának romlását jelentette. Ennek köszönhetően az inteferogramok láthatósága változott a mérés folyamán, ami a kiértékelés során elhanyagolhatóan kicsiny hibát eredményezett. A mérés eredményeit a IV.1.4. ábra szemlélteti.

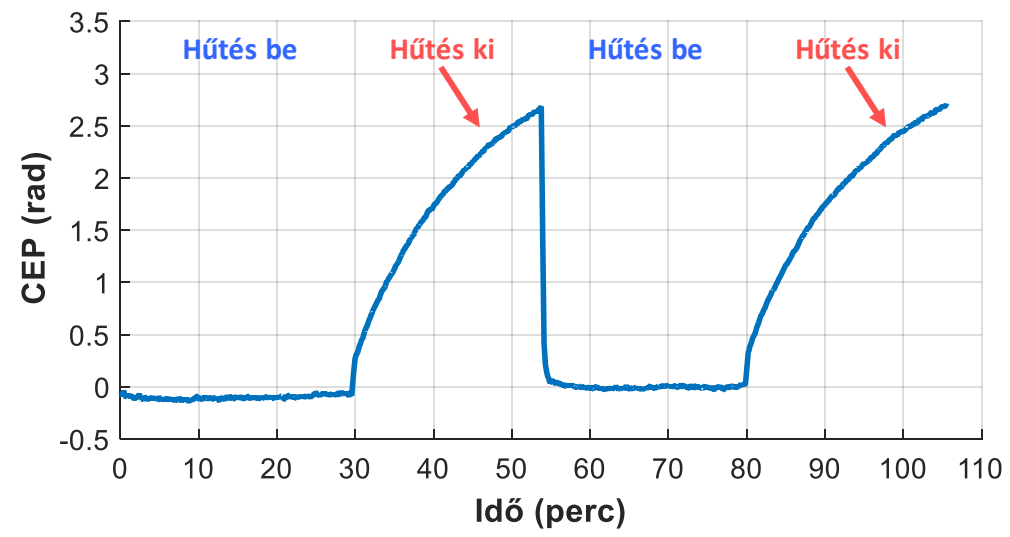

IV.1.4. ábra Ti:Sa kristály hütésének hatása a CEP-re. A tendencia jobb láthatósága érdekében az adatsort mozgó átlaggal simítottam.

A IV.1.4. ábrán a CEP változását a tárgykarban a 0. és a 30. perc, valamint az 54. és a 80. perc közötti szakaszokon a kristály vízhütésének müködése mellett, míg a 30. és az 54. perc közötti, illetve a 80. perc utáni részeken pedig a hütés müködése (átfolyás) nélkül mértem. Jól észrevehető, hogy a hütés megszünését követően a kristály pumpált térfogatának, amelyen a magimpulzusok áthaladnak, törésmutatója megváltozik, amely a hömérséklet emelkedésének tudható be. Ezáltal a CEP több mint 2,6 rad értéket csúszik el mintegy 24 perc alatt, és a fázisgörbe tendenciájából láthatóan a termikus egyensúly beállása ennyi idő után sem valósult meg. Amint a vízhűtés visszakapcsolásra került, a CEP közel ugyanarra az értékre áll vissza, amely a hủtés kikapcsolása előtt fennállt.

A fentiek alapján az már egyértelmü, hogy a pumpaimpulzusok abszorpciója révén bekövetkezö hőmérséklet-növekedés a CEP jelentős változását eredményezi, azonban kérdéses, hogy a hőhatás-e az egyetlen pumpa abszorpcióhoz köthető effektus. Ennek meghatározásához az egységnyi hőmérséklet növekedés esetén mérhető CEP-csúszás mérését tüztem ki célul. A CEP változását két esetben mértem a kristály hütésének folyamatos üzemeltetése mellett, a hütővíz hőmérsékletének változtatásával: nem pumpált és pumpált esetben.

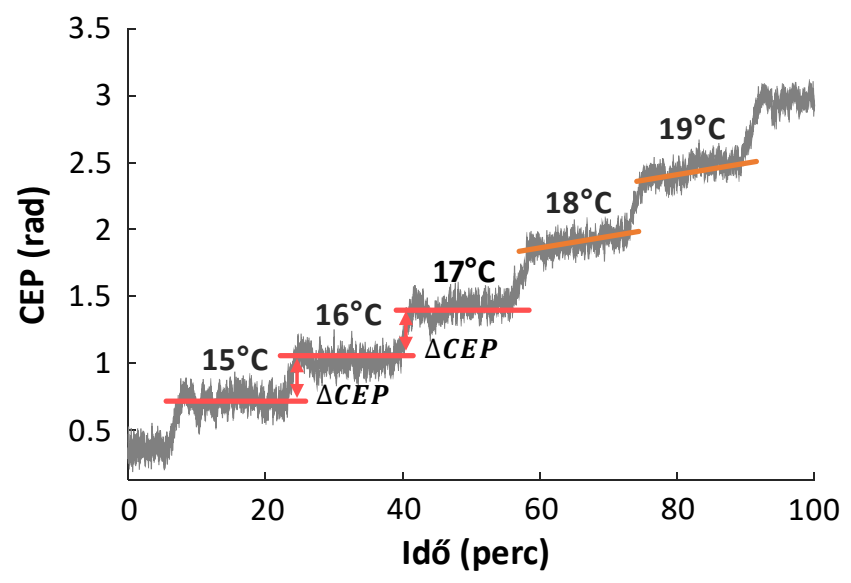

IV.1.5. ábra CEP léptetése a hütővíz hőmérsékletének segítségével. 
A hűtővíz hőmérsékletének élő monitorozásához a recirkulációs hűtőberendezés (Lytron) víztartályába egy a fázismérés során is használt számítógéphez kapcsolt Greisinger GMH3710 típusú hőmérőt helyeztem. Az első esetben, azaz pumpálás nélkül $20 \mathrm{~Hz}$ ismétlési frekvencián vettem fel az interferogramokat, miközben a hűtővíz hőmérsékletét $14^{\circ} \mathrm{C}$ és $20^{\circ} \mathrm{C}$ között változtattam (IV.1.5. ábra). Az egyes vízhőmérsékletek hűtőberendezésen való beállítását követően a kristálybéli hőmérsékleti egyensúly beállására közelítőleg 15 perc időintervallumokat hagytam. Ennek eredményeként $17^{\circ} \mathrm{C}$ hőmérsékletig a CEP stacionárius értéket vett fel az említett időtartamok alatt, azonban $18{ }^{\circ} \mathrm{C}$ hütővíz hőmérséklet esetén már a stacionárius állapot nem tudott az megadott idő alatt beállni. Ennek oka, hogy a hűtőberendezés hatásfoka $17^{\circ} \mathrm{C}$-nál magasabb hőmérsékletek esetén csökken, és így a hütővíz hőmérséklete nem áll be ilyen rövid idő alatt. Az egyes stacionárius CEP értékekre lineáris illesztést végezve, majd az egymást követő illesztések közötti $\triangle C E P$ csúszások meghatározásával az egységnyi hőmérsékletváltozásra eső CEP-változás értékét kaptam. Erre az értékre $446 \mathrm{mrad} /{ }^{\circ} \mathrm{C}$ adódott, amelyre vonatkozólag kiemelném, hogy ez az érték az erősítő kristályon való háromszori átmenetre vonatkozó eredmény. Összehasonlításképpen, a második esetben pumpálással együtt végeztem el ezt a kísérletet: $8 \mathrm{~mJ}$ pumpaenergia és 13 -as erősítés mellett $200 \mathrm{~Hz}$ ismétlési frekvencián mértem a hütővíz hőmérsékletének léptetésével a CEP csúszását ugyanazon körülmények között. Ugyanazon illesztési eljárást elvégezve az egyes hűtővíz hőmérsékletekhez tartozó fázisgörbe platók esetén, majd azok CEP értékeinek különbségeit véve a nem pumpált esettel megegyező értéket kaptam. Ebből arra következtethetünk, hogy a pumpaimpulzusok abszorpciójának a hőhatásán kívül a mérés pontosságán belül nem lehet kimutatni egyéb effektust a magimpulzusok CEP-jére vonatkozólag.

A kristály hőmérsékletének hatását másik erősítő elrendezésben is megvizsgáltam, amelyben egy az előzőtől eltérő paraméterekkel rendelkező Ti:Sa kristály teljesített szolgálatot. Konkrétan, a IV.1.1. alfejezetben röviden ismertetett második CPA rendszer előerősítőjének kristályát alapul véve egy Michelson-típusú interferométert építettem, amely rendkívül kompakt, mindössze $25 \mathrm{~cm}$ karhosszokkal rendelkezett (IV.1.6. ábra). Az interferométert az impulzusnyújtón áthaladt oszcillátor impulzusokkal világítottam ki. Miután a nyalábosztó elülső felületéről reflektált impulzusok áthaladtak a kristályon, azokat visszatükröztem ugyanazon útvonal mentén, amelynek megfelelően kétszeri áthaladás hatását mértem. A referencia karban levegöben terjedést hoztam létre, és egyetlen tükörrel visszalöttem ugyanazon útvonal mentén a nyalábosztóra, miközben a tükröt egy egytengelyủ eltolóval állítva hangoltam a két kar közötti időbeli késleltetést, vagyis az interferogramok sürüségét.

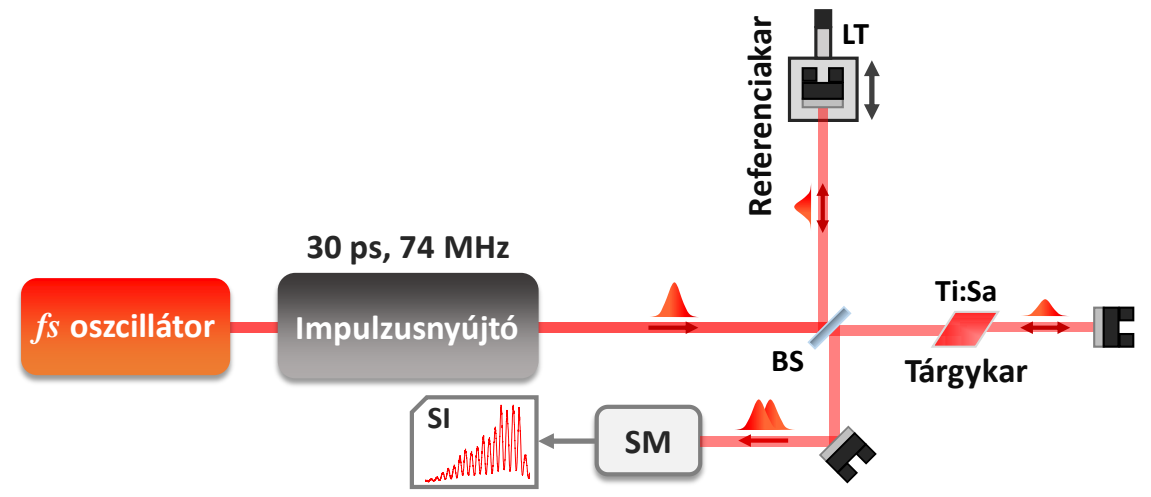

IV.1.6. ábra Kísérleti elrendezés a kristály hőmérsékletének hangolása által okozott CEP-csúszás mérésére az előerősítő kristályának felhasználásával. BS nyalábosztót, LT lineáris eltolót, SM spektrométert, Ti:Sa erősítő kristályt és SI spektrális interferenciát jelöl. 
Az interferométer bemenetén egy 50\%:50\%-os nyalábosztót helyeztem el, hogy a kimeneten jó láthatóságú interferogramokat kapjak, mivel a kísérlet során nem pumpáltam a kristályt. A mérés során a kristály hütését biztosító hủtőberendezésen hangoltam a hủtővíz hőmérsékletét a IV.1.4. ábrán látható léptetéshez hasonló fázisgörbét elóállítva, hogy az egyes lépcsőkre elsőfokú polinomot illesztve a CEP ugrásait meghatározzam. Az előerősítőben helyet foglaló Ti:Sa kristály Brewster-vágású, magas, $4.2 \mathrm{~cm}^{-1}$ abszorpciós együtthatójú, $6 \mathrm{~mm} \times 5 \mathrm{~mm}$ dimenziójú ( $5 \mathrm{~mm}$ hasznos úthossz) hengeres geometriával rendelkezett. Az interferométer kimenetét egy vonalas spektrométerbe (Thorlabs, CCS175) küldtem, amelyen a láthatóságot beoptimalizálva széles spektrális tartományon kaptam kiértékelhető interferencia csíkokat. A mérés során a hütővíz hőmérsékletét $10^{\circ} \mathrm{C}$ és $30^{\circ} \mathrm{C}$ között változtattam 15 perces időközönként. A IV.1.7. ábrán a mérésből származó CEP-csúszás egy részletét ábrázoltam, amin jól megfigyelhetők az egyes hütővíz hőmérsékleteknek megfelelő fázis platók. A platók közötti fázisugrásokat kiszámolva $110 \mathrm{mrad} /{ }^{\circ} \mathrm{C}$ érték adódott.

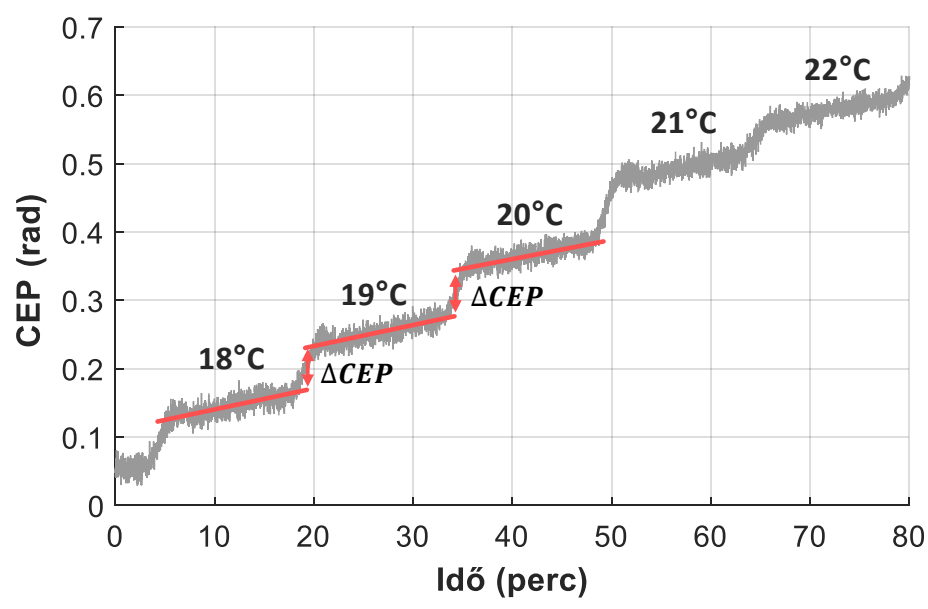

IV.1.7. ábra CEP változása a hűtővíz hőmérsékletének hangolásával. A jobb láthatóság kedveeert a mérés egy részletét ábrázoltam.

Egy modell segítségével meggyőződtem róla, hogy a mérések eredményei milyen mértékben egyeznek az elméletileg kapható értékekkel. Az egyszerüség kedvéért feltételeztem, hogy a kristály hőmérséklete homogén módon, a teljes pumpált, és az erősített impulzusok által érintett térfogatban ugyanannyival változik. Ekkor a zafír hordozó közegre a [69] munkában található, a lineáris törésmutató hőmérsékletfüggésére két hullámhosszon kapott értékeket felhasználva egy lineáris interpolációt végeztem el, amely által a hőmérséklettől és a hullámhossztól függő törésmutató függvényt nyertem $[168,169]$. Ezt a törésmutató függvényt felhasználva kiszámítható tetszőleges hosszúságú és hőmérsékletű kristályra a spektrális fázis változása a közegen való tetszőleges számú áthaladásra. A kristály hőtágulását is figyelembe véve, a IV.1.7. ábrán ismertetett eredményeknek megfelelő esetre $107 \mathrm{mrad} /{ }^{\circ} \mathrm{C}$ adódik $20{ }^{\circ} \mathrm{C}$-on, amely a mért $110 \mathrm{mrad} /{ }^{\circ} \mathrm{C}$ értékkel $2,7 \%$ eltéréssel megegyezik. A modellszámítást a IV.1.5. ábrán látható eredmények esetére elvégezve $451 \mathrm{mrad} /{ }^{\circ} \mathrm{C}$ adódott, amely 1,1\%-os eltéréssel megegyezik a mért $446 \mathrm{mrad} /{ }^{\circ} \mathrm{C}$ értékkel. Az eredmények alapján elmondható, hogy a Ti:Sa kristály hosszára normalizálva a CEP hőmérséklet-fluktuációk általi megváltozása $11 \mathrm{mrad} /{ }^{\circ} \mathrm{C} / \mathrm{mm}$ értékü, amit mind a mérések, mind pedig modell számítások alátámasztanak.

\section{IV.1.3. Lézerparaméterek hatásai}

A CEP zajának meghatározása elengedhetetlen fontosságú az inherens módon fázisstabil erősítők megvalósításához. Ehhez a CEP-zaj mérések során standard körülményként a magimpulzusok energiáját 
$65 \mu \mathrm{J}$ értékre állítottam be minden pumpaenergia és ismétlési frekvencia esetén az MZI tárgykarjában. A mérés háttérzaját $200 \mathrm{~Hz}$ ismétlési frekvencián mértem ki a Ti:Sa kristály pumpálása nélkül, miközben azt $16^{\circ} \mathrm{C}$-ra hütöttem le. A teljes elrendezést befedtem, hogy a légmozgás hatását minimálisra csökkentsem. A mérést továbbá esti órákban végeztem el, hogy az épület többi részéből származó mechanikai rezgések is eliminálhatóak legyenek. A háttérzajra az említett körülmények között 25 mrad RMS érték adódott, amit az alább ismertetésre kerülő mérési eredmények inherens módon tartalmaznak. Ezzel tehát a mérési elrendezés detektálási küszöbét kaptam meg.

Miután kimutatásra került, hogy a pumpaimpulzusok a CEP-re csak a hőterhelésükön keresztül hatnak a kísérlet paraméterein belül, a IV.1.2. ábrán ismertetett hárompasszos erősítő esetén megvizsgáltam azon két fontos lézerparaméter hatását, amelyek a hőterheléssel közvetlen kapcsolatban állnak: a pumpaimpulzusok energiáját, valamint az ismétlési frekvenciát (IV.1.8. ábra). A CEP-zaj értékét átlagolás nélkül, 5000 impulzusból álló adatsorokból számoltam ki, amely során a hosszútávú CEP-csúszásokat nem vettem figyelembe. A pumpaenergia növekedésével a IV.1.8. ábrán láthatóan közel lineárisan növekszik a CEP-zaj értéke, amely az így növekedő hőterhelést jelzi. Míg $20 \mathrm{~Hz}$ ismétlési frekvencián a 4,5 mJ pumpaenergia esetén közel $37 \mathrm{mrad}$, addig $8 \mathrm{~mJ}$ energia esetén már $91 \mathrm{mrad}$ értékre nőtt a CEP-zaj értéke. Az ismétlési frekvencia növelése esetén a zaj a legkisebb pumpaenergiától eltekintve csökkenő tendenciát mutat. Ez a tendencia legjobban $8 \mathrm{~mJ}$ pumpaenergia esetén figyelhető meg, amikor is 91 mrad-ról 42 mrad-ra csökken a CEP zajának értéke, ha az ismétlési frekvenciát 20 Hz-röl 200 Hz-re növeljük.

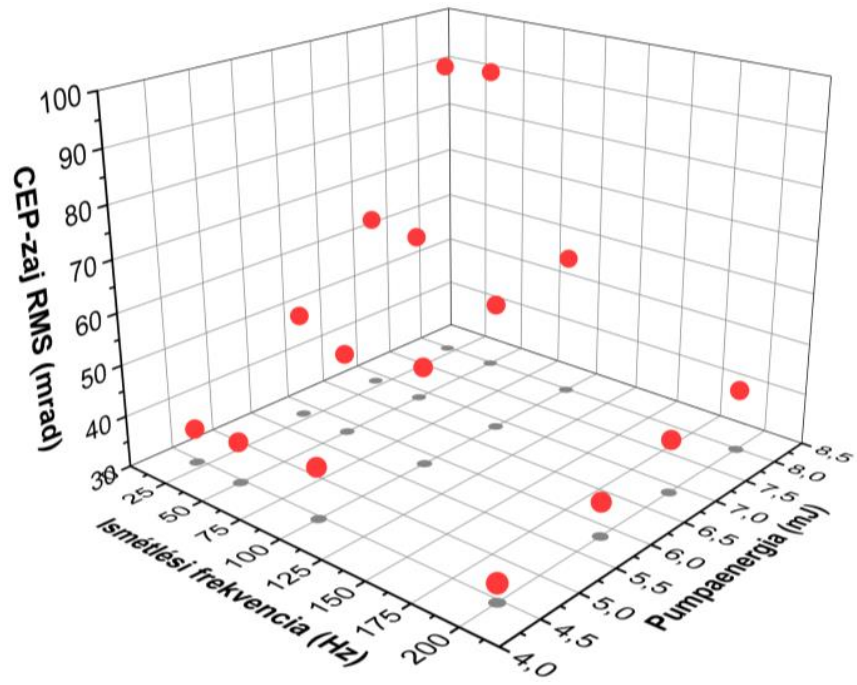

IV.1.8. ábra CEP-zaj az ismétlési frekvencia függvényében különböző pumpaimpulzus energiák esetén a hárompasszos erősítőben.

A hárompasszos minta erősítőbe becsatolt magimpulzusok energiáját változtatva megvizsgáltam annak hatását a CEP-zajra vonatkozóan. Egy attenuátor segítségével $10 \mu \mathrm{J}$ és $120 \mu \mathrm{J}$ között változtattam a magimpulzusok energiáját, miközben mértem a CEP zaját. A méréseket $200 \mathrm{~Hz}$ ismétlési frekvencián, $8 \mathrm{~mJ}$ energiájú pumpaimpulzusokkal történő gerjesztés mellett végeztem. Az eredmények szerint a magimpulzusok energiájának változtatása nem volt hatással a CEP zajára vonatkozóan a mérés pontosságán belül. Ebből arra következtethetünk, hogy az erősítés telítődése sem befolyásolja kimutatható mértékben a CEP zaját.

A nemlineáris fázisváltozásoktól származó CEP-csúszás meghatározásához kiszámoltam az erősítő kristályban, valamint a levegőben akkumulálódó nemlineáris fázis értékét. A Ti:Sa, valamint a levegő nemlineáris törésmutatójának [170] és a magimpulzusok csúcsintenzitásának fejlődését figyelembe 
véve a hárompasszos erősítőben egy egyszerủ modellt alkottam, amely megadja a nemlineáris fázistolás értékét az erősítő kimenetén. Az erősítő első passzában az kristály elülső felületén $0,1 \mathrm{GW} / \mathrm{cm}^{2}$ csúcsintenzitást feltételezve, amely megfelelt a kísérleti értékeknek, a teljes nemlineáris fázistolásra $12 \mathrm{mrad}$ adódott. Ennek az értéknek a túlnyomó többségét a Ti:Sa kristályban fellépő nemlineáris fázis akkumulációja adta. Tekintettel arra, hogy a mért CEP-zaj minden esetben nagyobb volt mint $30 \mathrm{mrad}$, a nemlineáris fázis változásából származó járuléka a mért CEP-zajhoz elhanyagolható.

\section{IV.1.4. Ismétlési frekvencia hatásának részletesebb elemzése}

A CEP-zaj és az erősített impulzusok ismétlési frekvenciája közötti összefüggést indokoltnak láttam egy másik erősítő fokozatban is megvizsgálni. Erre a TeWaTi felújított CPA rendszerét használtam fel. Kiváló lehetőség volt egy már müködő Ti:Sa erősítő egyik passzát megvizsgálni a korábbi módszerrel, amely az előerősítő esetében adott volt. Az előerősítő utolsó, tizedik passzát egy Mach-Zehnder típusú interferométer tárgykarjába foglalva egyetlen, az erősítő közegen való átmenet hatását mértem meg.

$30 \mathrm{ps}, 1 \mathrm{~mJ}$

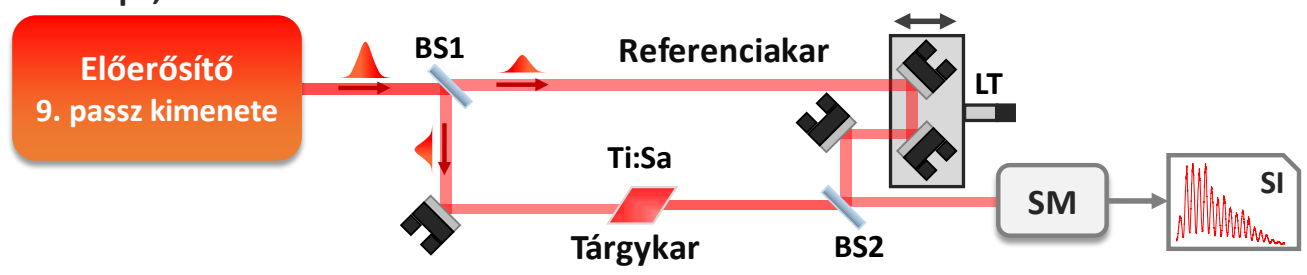

IV.1.9. ábra Mérési elrendezés az előerősítő 10. passzának CEP-re vonatkozó hatására. A Ti:zafír kristály pumpálásával kapcsolatos nyalábokat és optikákat az egyszerüség kedvéért nem tüntettem fel. BS1 és BS2 nyalábosztókat, LT lineáris eltolót, SM spektrométert, SI spektrális interferenciát jelöl.

A IV.1.6. ábrán jelölt mérési elrendezésben használt, $5 \mathrm{~mm}$ úthosszúságú Ti:Sa kristályon való egy átmenet méréséhez a IV.1.9. ábrán látható interferométert építettem fel. Az interferométer bemenetén egy 30\%/70\%-os nyalábosztót használva, kompenzálva az erősítés hatását, a tárgykarba a bemenő nyaláb intenzitásának 30\%-át csatoltam be.

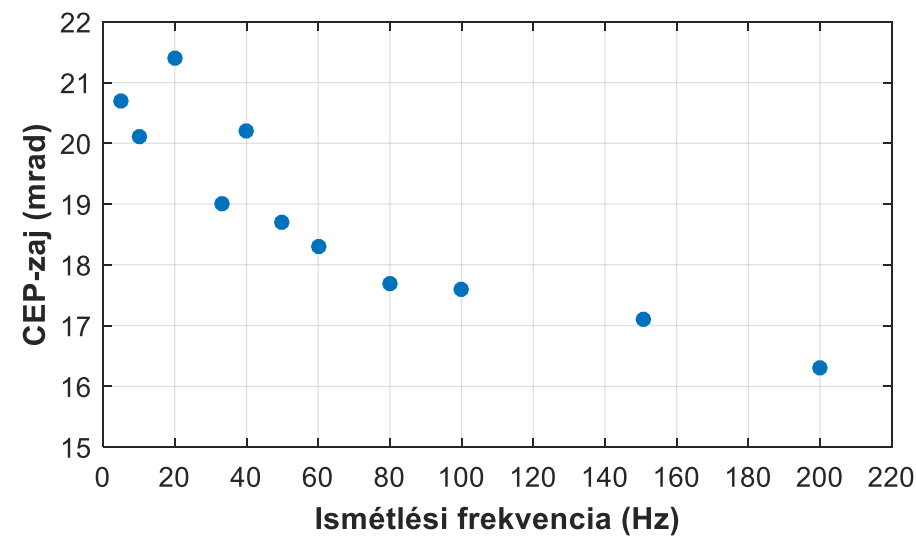

IV.1.10. ábra Mért CEP-zaj változása az ismétlési frekvencia függvényében egy átmenetes erősítésre.

Az interferométer kimenetén végül egy 50\%:50\%-os nyalábosztóval egyesítve a nyalábokat a korábban használt vonalas spektrométer segítségével rögzítettem az interferogramokat. Az erősítő kristályt az előerősítő működtetéséhez szükséges $20 \mathrm{~mJ}$ energiával pumpáltam, miközben változtattam a rendszer ismétlési frekvenciáját $5 \mathrm{~Hz}$ és $200 \mathrm{~Hz}$ között. A CEP-zaj értékét átlagolás nélkül, $10^{4}$ impulzusból álló adatsorokból számoltam ki $20 \mathrm{~Hz}$ ismétlési frekvenciáig, majd $10 \mathrm{~Hz}$ ismétlési frekvenciától már 10 percben limitáltam a mérési időt a lézerrendszer hosszútávú instabilitásának elkerülése miatt. Az 
ismétlési frekvencia növelésével a hárompasszos erösítő esetén is látott tendenciát kaptam vissza, miszerint a CEP-zaj értéke exponenciális jellegü csökkenést mutat (IV.1.10. ábra). A CEP-zaj IV.1.10. ábrán látható viselkedése azzal magyarázható, hogy az ismétlési frekvencia csökkenésével két egymást követő impulzus között egyre nagyobb időintervallum található. Ennek megfelelően az egyes impulzusok közötti termikus-, mechanikai- illetve légmozgásból származó zavarokból egyre több integrálódik be a mért zajba.

\section{IV.1.5. Diszkusszió}

A szobahőmérsékleten, vízhűtéssel üzemeltetett multipasszos Ti:Sa erősítők inherens CEPstabilitásának maximalizálásához szükséges a fázist degradáló effektusok azonosítása, és körültekintő tervezéssel való kiküszöbölése. Méréseim alapján a vízhűtő kör stabilitása kulcsfontosságú lehet mind a CEP elcsúszásának, mind pedig zajának szempontjából. Az ismétlési frekvencia függvényében végzett mérések eredményei azt mutatták, hogy az alacsonyabb frekvenciájú erősítők esetén a CEP-zaj megnövekszik. Ez annak köszönhető, hogy az egymást követő impulzusok között eltelt időtartam megnő, amely által a kristály hőmérsékletének megváltozása, valamint az erősítő geometriát körülvevő levegő mozgása és hőmérséklet-változása egyre nagyobb hatást fejt ki az impulzus fázisára.

Fontos megemlíteni, hogy a lézererősítőkben az impulzusok energiájának növekedésével passzról passzra egyre több nemlineáris fázis akkumulálódik, amit persze igyekeznek minimumon tartani az impulzusok kinyújtásával. Ugyanakkor, az impulzusnyújtás mértékét limitálja, hogy a magasabb diszperziós rendek kompenzálására milyen eszközök állnak rendelkezésre. A nagyenergiájú pumpalézerek tipikusan villanólámpával pumpált Nd:YAG technológiát használnak, amelyek jellegzetessége, hogy 1,5-2\% RMS energiastabilitást produkálnak. Az ilyen rendszerekben az erősített jel intenzitásának ingadozása amplitúdó-fázis csatolásként fog jelentkezni, amely a nemlineáris fázistolás révén CEP-zajt is eredményezhet. Méréseim során a Nd:YLF DPSS pumpalézer hosszútávú stabilitása $0,2 \%$ RMS értékü volt, amely révén a mérés érzékenységén belül a nemlineáris fázisváltozásból származó CEP-zajt nem tudtam detektálni. Továbbá, mindkét felhasznált CPA rendszer esetén az impulzusnyújtás elegendően nagy értékü volt ahhoz, hogy a B-integrál értéke alacsony legyen. Így a B-integrál impulzusról impulzusra bekövetkező változása elhanyagolható volt a mérések során.

Az erősítés során további, a CEP zaját befolyásoló effektus lehet a populáció inverzió által eredményezett törésmutató változás a Ti:Sa kristályban. Mivel a pumpaimpulzusok energiastabilitása miatt a populáció inverzió lövésről lövésre bekövetkező változásai alacsonyabb értéküek lehetnek csak, mint a mérés detektálási küszöbe, így az ebből az effektusból származó CEP-zaj járulék nem volt mérhetö.

A CEP erősítőbeli elcsúszásának stabilizálásához megfelelően stabil hủtőkört kell alkalmazni, valamint az erősítő elrendezés körüli légteret jól el kell szigetelni bármely légmozgástól. Továbbá, az optomechanikák beépítése során az optikai asztal szintjéhez minél közelebbi, kis nyalábmagasságot kell alkalmazni, hogy a mechanikai komponensek rezgéseit minimalizáljuk, ami úthosszváltozást eredményez a levegőben való terjedés során. A CEP-zajra vonatkozólag elmondható, hogy a pumpaimpulzusok energiájának növelésével lineárisan növekszik. Ezen felül, az ismétlési frekvencia csökkenésével a CEP-zaj exponenciális jellegü növekedést mutat, ami az egymást követő impulzusok közötti időtartam növekedése miatt következik be. Ugyanis, az impulzusok közötti időtartammal együtt a fáziszajba integrálódó termikus és mechanikai eredetű zajok mennyisége megemelkedik. Ennek fényében, a nagy energiájú, villanólámpával pumpált és alacsony ismétlési frekvenciájú erősítő rendszerek a leginkább érintettek a CEP-instabilitásokra vonatkozóan. A nagy ismétlési frekvenciájú, 
DPSS pumpalézerekkel meghajtott erősítő rendszerek passzív módon fázisstabilabbak lehetnek, csupán a hosszútávú CEP-csúszások korrekciója válik mindenképpen szükségessé.

T1. Megvizsgáltam a vízhütéses Ti:Sa erősítés CEP-stabilitását a lézerparaméterek függvényében. A CEP csúszására egységnyi hőmérséklet-változásra, a kristály hosszára normalizálva $11 \mathrm{mrad} /{ }^{\circ} \mathrm{C} / \mathrm{mm}$ értéket mutattam ki. Megállapítottam, hogy az erősített impulzusok CEP-zaja a pumpaenergiával lineárisan növekszik, míg az ismétlési frekvenciával exponenciális jelleggel csökken. A magimpulzusok energiája a CEP csúszására és zajára a mérés érzékenységén belül nem volt hatással [TP1]. 


\section{IV.2. Kriogenikus hütésű Ti:Sa erősítők fázisstabilitása}

Nagy átlagteljesítményű ultrarövid impulzusok elóállítása Ti:Sa lézererősítőkben az erősítő közeg kvantum defektusa miatt jelentős hőterhelést jelent az abszorbeált pumpaenergia hődisszipációja révén. $\mathrm{Az}$ erősítő kristály hőmérsékletének emelkedése a pumpált térfogatban az erősítendő nyaláb torzulásaihoz fog vezetni, így termikus lencse, termikus eredetü mechanikai feszültség, illetve depolarizációs effektusok léphetnek fel [171]. Bár a Ti:Sa magas szobahőmérsékleten mért hővezetési együtthatóval rendelkezik, nagy átlagteljesítményü pumpálás esetén az általában alkalmazott vízhütés nem képes elegendő hő kicsatolására a kristályból. Amennyiben a kristály hőmérsékletét kriogenikus értékekre csökkentjük $(<80 \mathrm{~K})$, annak hővezetési együtthatója jelentősen megnövekszik, mégpedig a $293 \mathrm{~K}$-en mért $35 \mathrm{~W} /(\mathrm{m} \cdot \mathrm{K})$ értékről $77 \mathrm{~K}$-en $1000 \mathrm{~W} /(\mathrm{m} \cdot \mathrm{K})$, addig $30 \mathrm{~K}$ hömérsékleten már $1,6 \cdot 10^{4} \mathrm{~W} /(\mathrm{m} \cdot \mathrm{K})$ körüli értékre emelkedik meg kristálymintától függően (a kristály két polarizációs irányához tartozó hővezetési értékek kis mértékben különböznek) [75,76]. Emiatt gyakran alkalmaznak kriogenikus hütést a nagy átlagteljesítményü erősítők esetén, jellemzően folyékony nitrogén alapú hütőfejek felhasználásával. A termikus eredetü nyalábtorzulások ilyen módon jelentősen csökkenthetőek. Ugyanakkor a kriogenikus hủtés sem alkalmazható hátrányok nélkül: a rendkívül alacsony hőmérséklet miatt a kristályt vákuumkamrában kell elhelyezni, hogy a levegőben lévő víztartalom, illetve egyéb szennyeződések kicsapódását a hütött anyagok felületén megakadályozzuk. A vákuum technológia müködtetése jelentős mennyiségü mechanikai vibrációt generál, amely az optikák rezgésén keresztül az erősítendő impulzusokra is átrakódik spektrális fáziszaj formájában, amely pedig számos alkalmazás szempontjából kritikus lehet.

\section{IV.2.1. Kísérleti módszer és elrendezés}

Méréseim során a korábban már leírt SRI módszert használtam fel a spektrális fázis, valamint a CEP zajának meghatározásához. Gyakorlati tapasztalatok szerint, megfelelően megtervezett és megvalósított, mechanikailag kellően stabil interferométerrel akár $10 \mathrm{mrad}$ körüli detektálási limitet is elérhetünk a spektrális fázis zajára vonatkozóan. Mivel azonban a mért spektrális fáziszaj jellemzően a csoportkésleltetés fluktuációjából származik, a CEP zajának detektálási határa akár egy nagyságrenddel alacsonyabb is lehet. A mérési elrendezés alapzaja az interferométer karhosszainak, valamint az alkalmazott reflexiós optikák számának csökkentésével tartható minimális értéken.

A mérés alapzajának csökkentése érdekében a kriogenikusan hütött Ti:Sa erősítőt egy kis karhosszúságú Michelson-típusú interferométer tárgykarjában építettem fel. A tárgykar fényútját úgy valósítottam meg, hogy az kétszer haladjon át a kristály pumpált térfogatán, amely eredményeképpen kétpasszos erősítést nyertem. A teljes kísérleti elrendezést a IV.2.1. ábra szemlélteti. Mind a tárgy-, mind pedig a referencia karban leképezést valósítottam meg egy-egy akromatikus lencse és gömbtükör alkalmazásával, amelyre a kis nyalábméret miatt volt szükség. A kis nyalábméret tartását az indokolta, hogy a Ti:Sa kristályban, valamint a vákuumkamra ablakaiban a rövid távolságon fókuszált nyaláb csúcsintenzitása ne érjen el olyan szintet, amely már jelentős nemlineáris fázisjárulékot eredményezne. A referencia karban az akromatikus lencsén túl egyéb optika nem kapott helyet, így lényegében levegőben való terjedést valósítottam meg. Fontos megjegyezni, hogy az interferométer két karja közötti diszperzió-különbséget a Ti:Sa kristály, valamint a két vákuumablak jelentette, amely közelítőleg $1480 \mathrm{fs}^{2}$ GDD különbséget eredményezett. Ez a csoportkésleltetés diszperzió eltérés a két kar között tolerálható mértékben módosította az interferencia mintázatot, a kiértékelésben hibát nem okozott. Az interferométer be- és kicsatolását egy 70\%:30\% reflexió-transzmisszió arányú nyalábosztó biztosította. 
Fényforrásként a TeWaTi laboratórium felújított CPA rendszerét használtam fel, amely végén lévő impulzuskompresszort kikerülve a nyújtott és erôsített impulzusokat csatoltam be az interferométer bemenetén. A CPA rendszer kompresszor nélküli diszperziója alapján az impulzusok hossza 30 ps körüli volt, míg standard körülmények között az interferométer bemenetén az impulzusok mért energiája $20 \mu \mathrm{J}$ körüli értékre lett beállítva. A minta erősítőt a IV.1. fejezetben ismertetett DM30-527 pumpalézerrel hajtottam meg. A pumpaimpulzusok energiáját $10 \mathrm{~mJ}$ értéken tartottam minden vizsgált ismétlési frekvencián. Az erősítés intenzitásbéli hatásának optimális kompenzálásához egy neutrális reflektív szürőt helyeztem el a tárgykarban, amelyen való kétszeri áthaladással biztosítottam a két kar közötti intenzitáskülönbség minimális értéken tartását.

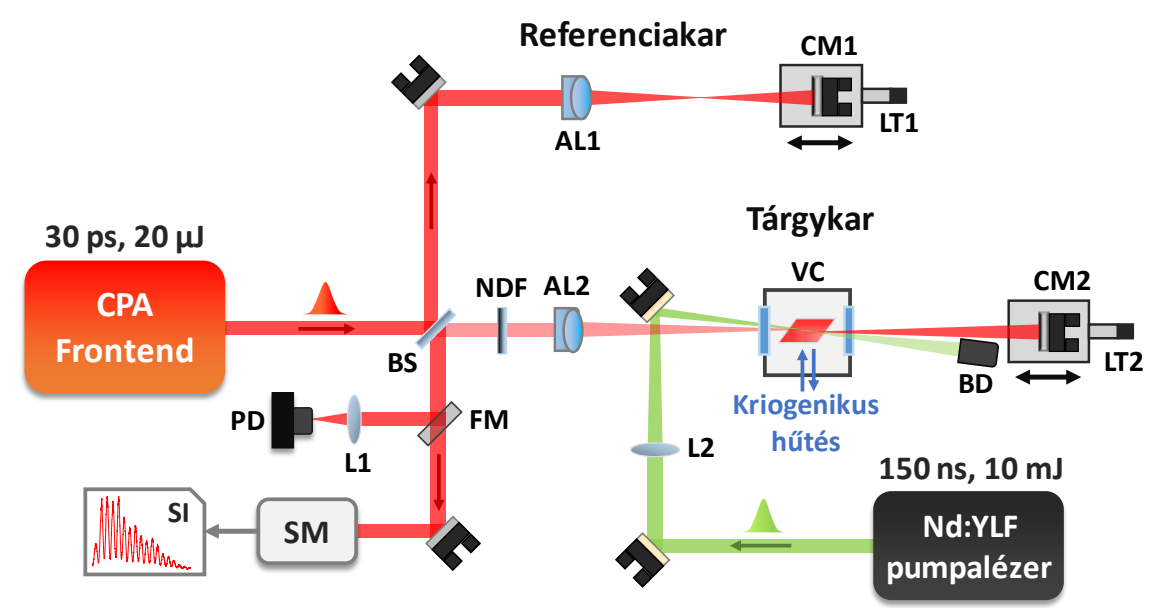

IV.2.1. ábra Mérési elrendezés a fázisstabilitás vizsgálatára a kriogenikus hűtésű Ti:Sa erősítő esetén. BS nyalábosztót, AL1 és AL2 akromatikus lencséket, NDF reflektív neutrális szürőt, L1 és L2 lencséket, CM1 és CM2 konkáv tükröket, LT1 és LT2 lineáris eltolókat, VC vákuumkamrát, BD nyalábcsapdát, FM csapótükröt, PD fotodiódát, SM spektrométert, SI pedig spektrális interferenciát jelöl.

Az interferométer kimenete után csapótükör segítségével egy megfelelően gyors fotodiódára (Thorlabs, DET10A/M) irányítottam a nyalábot, amit le is fókuszáltam a kicsiny detektorfelület miatt. Az erősítés optimalizálását a referenciakar kitakarásával végeztem el a fotodióda jelének oszcilloszkópon való vizsgálatával. A tárgy- és a referenciakar hozzájárulásával keletkező interferencia mintázatot egy egyedi építésü spektrométer segítségével vettem fel. A spektrométer detektoraként egy Basler spL2048-70km típusú vonalkamerát használtam fel, amely 2048 pixellel és $70 \mathrm{kHz}$ maximális frissítési frekvenciával rendelkezett. A spektrális felbontást úgy optimalizáltam be, hogy az impulzusok teljes spektrumát fel tudjam bontani, amely $765 \mathrm{~nm}$ és $845 \mathrm{~nm}$ közötti spektrális tartományt fedett le $0,039 \mathrm{~nm}$ felbontással 800 nm-en. A spektrométer szoftveres vezérlését egy LabView (National Instruments) alapú kód segítségével végeztem el.

A tárgykarban megépített erősítő alapját egy Brewster-szögben kivágott, $5 \mathrm{~mm}$ úthosszal és $6 \mathrm{~mm}$ átmérővel rendelkező Ti:Sa kristály szolgáltatta, amely a pumpa hullámhosszán $4.27 \mathrm{~cm}^{-1}$ mért abszorpciós együtthatóval rendelkezett. Tekintettel a kivágási szögre, a kristály mindkét optikai felülete bevonattól mentes volt. A kristály egy forgatható réz foglalatban kapott helyet, amely közvetlenül egy CryoMech PT60 típusú kriogenikus hütőfej hidegujjához került rögzítésre. A hütött foglalat egy kompakt vákuumkamrába lett foglalva, amiben 3 darab BK7 anyagú vákuumablak kapott helyet. A két egymással szemben lévő ablakon keresztül haladt az erősítendő- és a pumpanyaláb, addig a harmadik ablak pedig optikai megfigyelésre adott lehetőséget a kristály és nyalábok pozíciójára vonatkozóan. A kriogenikus hütő minimális hőmérséklete terhelés nélkül $30 \mathrm{~K}$ körüli értéken tartható, amely a hőterheléstől függően változik. Tekintettel a rendkívül alacsony hőmérsékletủ foglalatra és kristályra a 
müködési kondíciók mellett, a vákuumkamrát igen alacsony, $10^{-6}$ mbar körüli nyomásra szívtam le, amihez egy HiPace 80 (Pfeiffer Vacuum) típusú turbópumpát használtam fel.
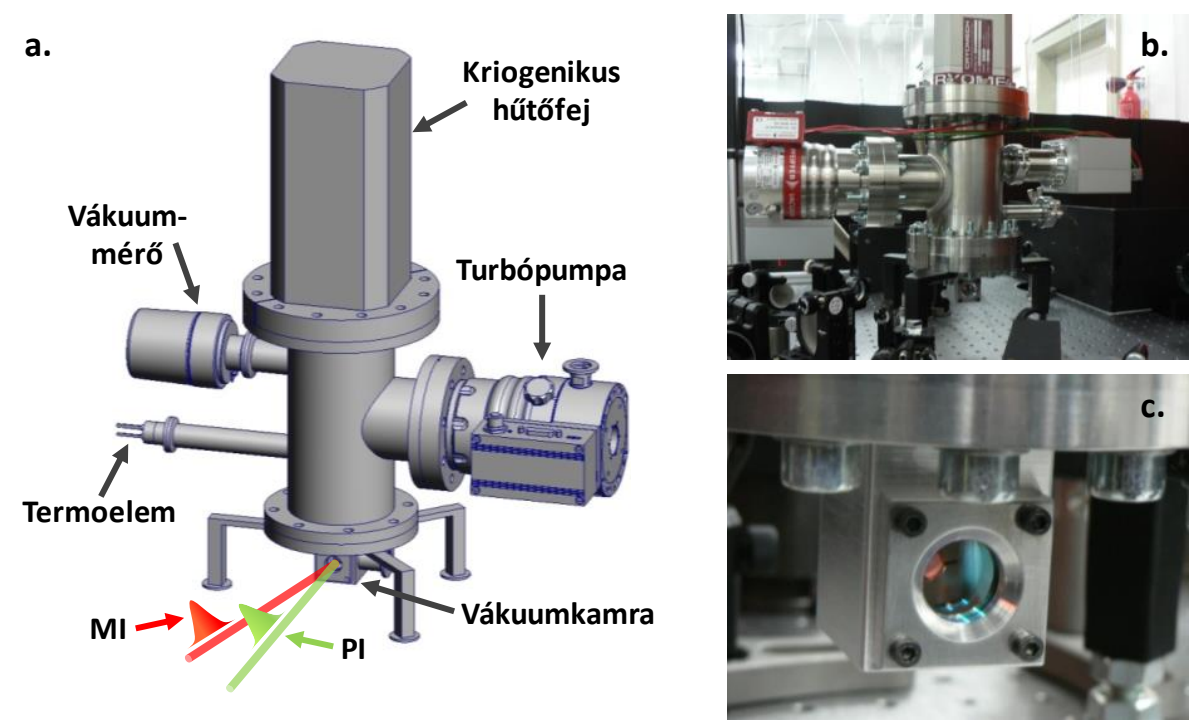

IV.2.2. ábra Kriogenikus hütő modul háromdimenziós terve a turbópumpával és a kompakt vákuumkamrával (a), ahol MI magimpulzusokat, PI pedig pumpaimpulzusokat jelöl. Fénykép a megvalósított modulról (b) és a vákuumkamráról (c), amelyen a Ti:Sa kristály jól kivehető a réz foglalatban.

A turbópumpa bekapcsolásához szükséges elővákuumot a rezgések csökkentése miatt mérési elrendezéstől mintegy $5 \mathrm{~m}$ távolságban, a laboron kívül elhelyezett XtraDry 150-2 (Pfeiffer Vacuum) típusú elővákuum-szivattyú biztosította. Mivel a turbópumpa rotorjának, valamint a kriogenikus hütőfejben található héliumnak a mozgása jelentős mechanikai rezgéseket generált, a IV.2.2. ábrán látható elrendezés alá gumi lapokat helyeztem el az optikai asztallal való mechanikai csatolás csökkentésének érdekében.

A mechanikai vibrációk vizsgálatához egy Hansford HS100 típusú gyorsulásmérö került rögzítésre az optikai elrendezéstől $20 \mathrm{~cm}$ távolságban az optikai asztal felületén. Az eszköz érzékenysége $516,6 \mathrm{mV} / \mathrm{G}$ értékre volt kalibrálva. Mivel a gyorsulásmérő analóg jelet szolgáltatott, azt egy NI USB6009 típusú konverter segítésével digitalizáltam, valamint a méréseket vezérlő számítógéphez kötve végeztem az adatok kinyerését.

\section{IV.2.2. Kiértékelési módszer és zajforrások azonosítása}

A mérési eredmények kiértékelését a vízhütéses Ti:Sa erősítő esetén is alkalmazott Fouriertranszformációs módszer segítségével végeztem el. A spektrális fázist ennek megfelelően az interferogramból kinyert fázisgörbére polinomillesztéssel határoztam meg. Fontos azonban megemlíteni, hogy jelen esetben a mechanikai vibrációk jelentős fázisjárulékot eredményeztek. A kiértékelés hibájának csökkentése miatt elsőként másodfokú polinomot illesztettem a kinyert fázisgörbékre, amelyböl meghatároztam az interferométer két karja közötti GDD különbséget. Majd ezt felhasználva, a fázisból kivonva a kapott GDD értékekből számolt másodrendü fázistagot, elsőrendủ polinomot illesztettem a GDD-vel korrigált, immáron jó közelítéssel elsőrendü fázisgörbére, amelyből megkaptam a központi hullámhosszon a $\varphi_{0}$ spektrális fázist, illetve a GD értékét. Mivel az elsőrendü polinom illesztésével alacsonyabb kiértékelési hiba nyerhető az imént említett két mennyiségre, ez az eljárás minden mérési eredménynél felhasználásra került. 
Tekintettel a $G D \cdot \omega_{0}$ zajára, amely jelentősen nagyobb értékü volt, mint a $\varphi_{0}$ esetén, a CEP csúszásának kinyerése az adatsorokból a (II.33) kifejezés segítségével hibás eredményeket szolgáltatott. Ennek oka, hogy a $G D \cdot \omega_{0}$ fázistag zaja jellemzően közel kétszerese volt a $\varphi_{0}$ zajának, amely hamisan túl nagy CEP zajt eredményezett (IV.2.3. ábra).
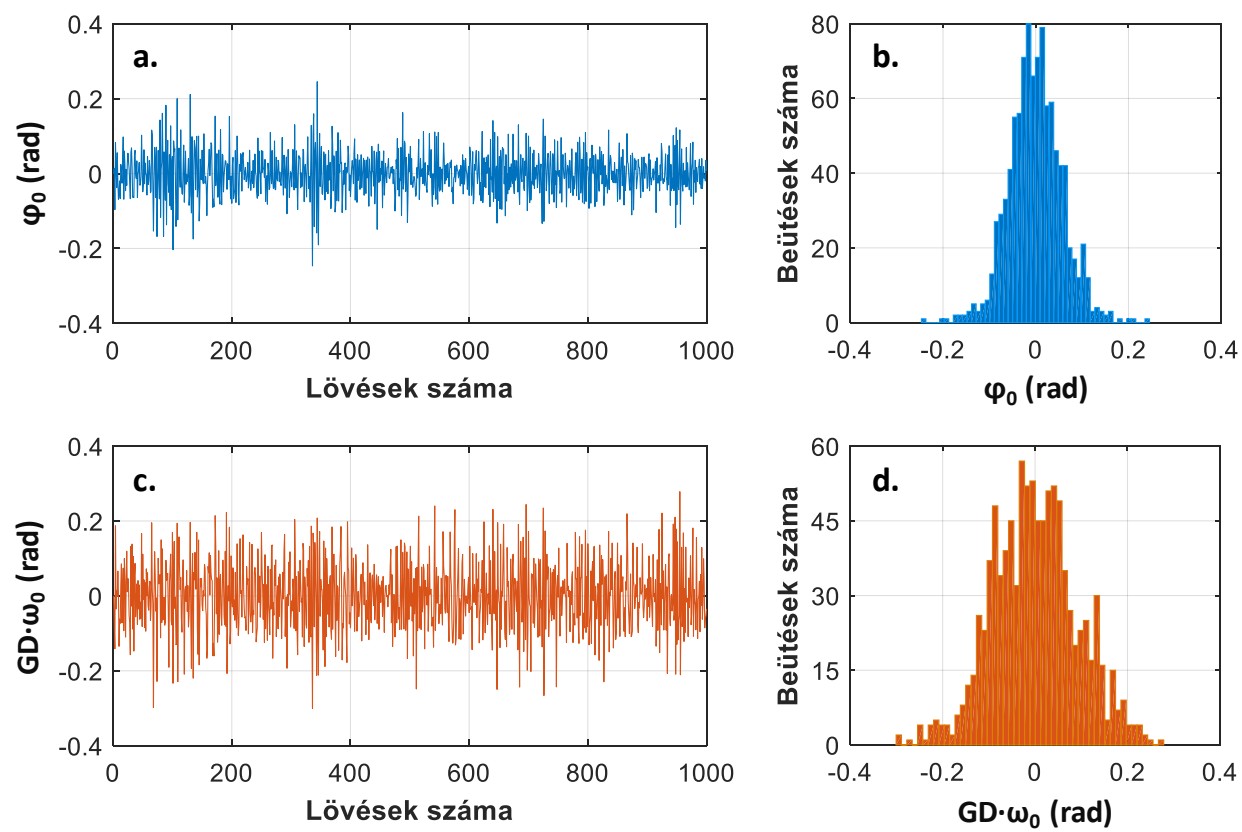

IV.2.3. ábra 1000 impulzus $\varphi_{0}(\mathrm{a})$, illetve $G D \cdot \omega_{0}$ (c) zaja. A mérést $100 \mathrm{~Hz}$ ismétlési frekvencián végeztem. A fáziszaj eloszlását a nulladik rendủ tagra (b), míg az elsőrendủ tagra (d) részek szemléltetik hisztogram formájában. Az $\varphi_{0}$ zajára 57,2 mrad, addig a $G D \cdot \omega_{0}$ zajára $92 \mathrm{mrad}$ RMS adódott.

Ahhoz, hogy a spektrális fázis mellett a CEP értékét is meg tudjuk határozni a mért adatokból, tekintsük át az erősítés során fellépő azon effektusokat, amelyek az erősített impulzusok CEP-jét befolyásolhatják. Bár a kriogenikus hütés rendkívül hatékony hőkicsatolási módszer, a mérések során használt $10 \mathrm{~W}$ átlagteljesítményű pumpálás még így is jól kimutatható hőmérsékletváltozást tud eredményezni a kristály pumpált térfogatában. A hőmérséklet-változás módosítja a kristály törésmutatóját, amely hullámhosszfüggése miatt CEP-változást is okoz. Tekintettel a mérésben jelen lévő GD-zajra, kismértékben az erősítő elrendezésben létrejövő légmozgás is hozzájárul a tükrök mozgásán túl a CEP változásához. A nemlineáris effektusokat tekintve két jelenséget érdemes megemlíteni, ezek a Kerreffektus, valamint a populáció-inverzió által létrejövő törésmutató változás. Az erősítendő nyaláb átmérőjét az előbbi effektus elkerülése miatt úgy állítottam be, hogy az interferométerbe való belépés előtt egy teleszkóp segítségével $1 \mathrm{~mm}$ körüli értékre csökkentettem. Ezáltal, a vákuumkamra két ablakában, valamint a Ti:Sa kristályban felhalmozódó nemlineáris fázistolást elhanyagolható értékre csökkentettem, tekintve, hogy az impulzusok időben nyújtottak voltak, valamint a kristályban vett nyalábátmérő $400 \mu \mathrm{m}$-nél nem volt kisebb. Végül pedig megvizsgáltam a populáció inverzió hatását is, amire az irodalomban található adatok alapján azt találtam, hogy a törésmutató változása a vizsgált spektrális tartományon a hullámhossztól effektíve függetlennek tekinthető [172]. Emiatt az erősített impulzusok CEP-jét az inverzió nem, vagy csak elhanyagolható mértékben módosíthatja.

A mérések során kimutatható két föbb zajforrást az impulzusok CEP-jére nézve a kristály hőmérséklet változása, valamint az interferométerben lévő légmozgás és a tükrök rezgése jelentette. Az utóbbi esetén a levegőben terjedés hosszának változása eredményez CEP-változást. Az erősítő kristály pumpálása nélkül az optikai elrendezésben az utóbbi forrásból származik a CEP eltolódás, amennyiben 
a kristály hőmérséklete állandó értéken van tartva, amely a kísérlet során jól teljesül is. Ebben az esetben a CEP eltolódását a (II.13) és (II.21) kifejezések alapján elsőrendü közelítésben a

$$
\Delta \varphi_{C E, \text { vibráció }}=\Delta \varphi_{0} \cdot\left(1-\left.\omega_{0} \frac{\Delta G D}{\Delta \varphi_{0}}\right|_{\text {levegó }}\right)
$$

formulával kapjuk. Fontos, hogy az elsőrendű közelítés alkalmazása a relatíve szük spektrális tartomány miatt elhanyagolható hibát eredményez. A (IV.1) kifejezésre vonatkozóan a (II.21) egyenlet alapján levezethetö a GD és a $\varphi_{0}$ viszonyára a

$$
\frac{G D}{\varphi_{0}}=\frac{1}{\omega}+\frac{1}{n_{\text {levegö }}(\omega)} \frac{d n_{\text {levegö }}(\omega)}{d \omega}
$$

alakú formula, ahol $n_{\text {levegö }}(\omega)$ a levegő frekvenciafüggő törésmutatója. Az $\omega_{0}$ központi frekvencián (IV.2) kifejezésből megkapható a $\Delta G D / \Delta \varphi_{0}$ együttható értéke, amelyre 424,7 as/rad adódik. Észrevehető, hogy ez a hányados határozza meg a $\varphi_{0}$ és a GD csatolását. Hasonló módon, a Ti:Sa kristály pumpált térfogatának hőmérséklet-változása esetén elsőrendü közelítésben az előző egyenlettel megegyezö alakú,

$$
\Delta \varphi_{C E, \text { termikus }}=\Delta \varphi_{0} \cdot\left(1-\left.\omega_{0} \frac{\Delta G D}{\Delta \varphi_{0}}\right|_{T i: S a}\right)
$$

formula adja a CEP eltolódásának értékét a mért spektrális fázis, illetve a hőmérséklet-változás esetén érvényes csatolási együttható felhasználásával. A (IV.1) és (IV.3) formulákban található együtthatókat két külön eljárás segítségével határoztam meg. Az erősítő kristály hőmérséklet-változásához rendelhető koefficiens értékét a kriogenikus hűtőfej bekapcsolási procedúrája során rögzített interferogramok kiértékeléséből kaptam. Mindezt oly módon, hogy a kristály lehülése által bekövetkező GD változást a spektrális fázis központi hullámhosszon vett értékének függvényében ábrázoltam, majd a kapott görbére elsőfokú polinomot illesztettem (IV.2.4. ábra, (a) rész).
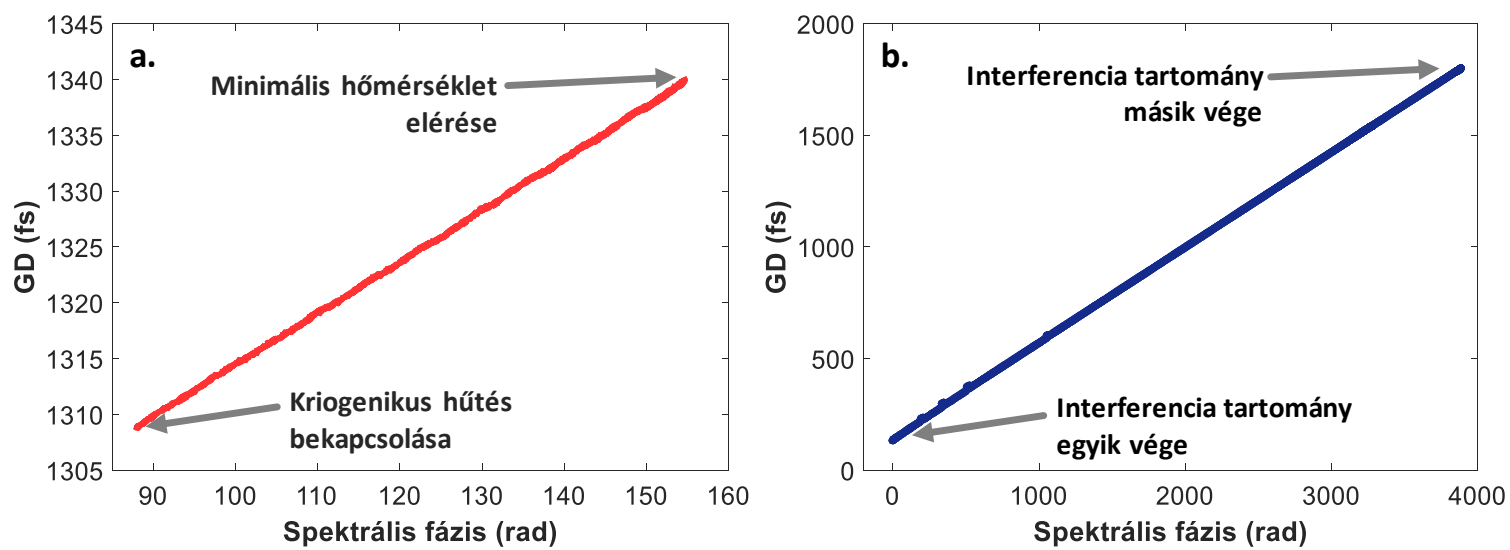

IV.2.4. ábra Csoportkésleltetés a $800 \mathrm{~nm}$ központi hullámhosszon mért spektrális fázis függvényében a kriogenikus hủtő bekapcsolási folyamata során (a), valamint a referenciakarban található lineáris eltoló pozíciójának egyirányú változtatása közben (b).

Ezek után a vibrációhoz köthető együtthatót pedig az interferométer referencia karjában lévő lineáris eltoló egyirányú mozgatásával egyidejüleg rögzített interferogramok termikus esetben már leírt módon való kiértékelésével határoztam meg (IV.2.4. ábra, (b) rész). A GD $\left(\varphi_{0}\right)$ görbéket $200 \mathrm{~Hz}$ ismétlési 
frekvenciájú, $20 \mu \mathrm{J}$ energiájú impulzusok segítségével mértem meg. A kriogenikus hűtő bekapcsolási folyamata során végzett mérésből származó adatokra illesztést végezve, a meredekségre 462,4 as/rad $\pm 0,1$ as/rad adódott. Ez a $\left(\Delta G D / \Delta \varphi_{0}\right)_{T i: S a}$ koefficiens megadja a hőmérséklet-változás esetén érvényes csatolást a GD és a $\varphi_{0}$ között. Hasonló módon, a lineáris eltoló lassú mozgatásával kapott adatokra illesztve a $\left(\Delta G D / \Delta \varphi_{0}\right)_{\text {levegó }}$ együtthatóra $427,1 \mathrm{as} / \mathrm{rad} \pm 0,1 \mathrm{as} / \mathrm{rad}$ adódott. Az így kapott együttható értéke jó egyezést mutat a (IV.2) kifejezésből számolt értékkel. A CEP zajának meghatározását a későbbiekben ezen együtthatók felhasználásával végeztem el.

\section{IV.2.3. Vákuum- és hütőrendszer hatásainak mérése}

Mint minden mérési rendszer esetén, jelen esetben is elsőként a Michelson-interferométerben inherens módon jelen lévő spektrális fáziszajt kellett meghatároznom, amely a mérések detektálási határát adja meg. Ehhez az elrendezés három különböző működési állapotában végeztem méréseket az erősítő kristály pumpálása nélkül: elsőként a mérendő impulzusok úgy haladtak át az interferométeren, hogy a rendszer passzív volt („háttér”); majd az elővákuum-szivattyút és a turbó pumpát bekapcsolva és megvárva azok normális üzemi paramétereinek beállását („vákuum”), végül a vákuumrendszerek müködése mellett bekapcsolva a kriogenikus hütőegységet, és megvárva a minimális hőmérséklet elérését („,cryo”) küldtem át az impulzusokat az elrendezésen. Az ilyen módon felvett spektrális interferencia kiértékeléséből kapott $\varphi_{0}$ zaját a IV.2.5. ábra szemlélteti.

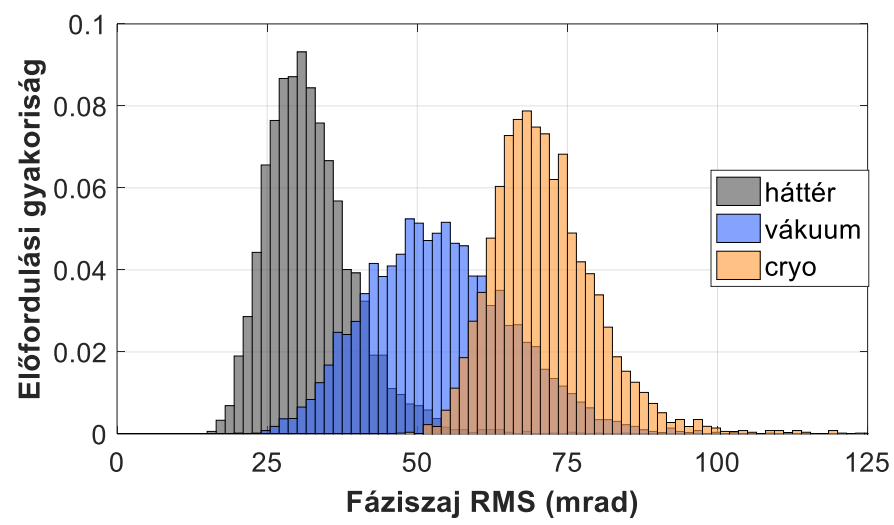

IV.2.5. ábra Spektrális fáziszaj eloszlása három különböző esetre: háttér (szürke), vákuum rendszerek üzemelése (kék) és a kriogenikus hủtőegység (és a vákuum rendszereké) működése során (sárga).

A mérések elvégzéséhez $16 \mu \mathrm{J}$ energiájú impulzusokat küldtem be az interferométerbe $1 \mathrm{kHz}$ ismétlési frekvenciával, hogy kellő mennyiségű adatot tudjak gyüjteni rövid idő alatt a rendszer hosszabb távú változásainak elkerülése miatt. A kiértékelés során az $1 \mathrm{kHz}$-es impulzussorozatból 100 impulzusos periódusokat kiválasztva számoltam ki a fáziszaj RMS értékét, majd a teljes adatsorra nézve meghatároztam a kapott RMS értékek eloszlását. Az első müködési fázisban (passzív stabilitás, nincs aktív eszköz) 32 mrad RMS fáziszaj volt mérhető, amely a mérési elrendezés alapzaját jelentette (IV.2.5. ábra, szürke hisztogram). Miután az elővákuum-szivattyút, illetve a turbó pumpát is üzembe helyeztem, a zaj 54 mrad RMS értéküre nőtt (IV.2.5. ábra, kék hisztogram). Végül a kriogenikus hütő üzemelése során, amely kondíciók eléréséhez 30 percet kellett várnom a bekapcsolástól számítva, a fáziszaj már 72 mrad RMS értékre emelkedett (IV.2.5. ábra, sárga hisztogram). Mivel az egyes eszközök független zajforrásoknak tekinthetőek, a fáziszaj járulékaik geometriailag összegződnek. Ez alapján meghatároztam, hogy a vákuum-rendszerek mintegy $43 \mathrm{mrad}$, addig a kriogenikus hütőfej $47 \mathrm{mrad}$ RMS fáziszajt eredményeznek egyenként. Mindezek pontos frekvenciaeloszlásaira vonatkozólag a IV.2.5. alfejezetben fogok kitérni. 


\section{IV.2.4. Ismétlési frekvencia és erősítés hatásai}

Változtatva a mag- és pumpaimpulzusok ismétlési frekvenciáját megvizsgáltam, hogy az erősítőn való áthaladás miként változtatja meg a magimpulzusok CEP-zaját az egymást követő impulzusok között eltelt időtartam megváltozásának függvényében. A mérés során a $20 \mu \mathrm{J}$ energiájú magimpulzusok ismétlési frekvenciáját 50 és $1000 \mathrm{~Hz}$ között változtattam a lézerrendszer időzítő elektronikáját felhasználva (Thales Laser, Masterclock). A mérések során a Ti:Sa kristályt $10 \mathrm{~mJ}$ energiájú pumpaimpulzusokkal gerjesztettem, amelyek ismétlési frekvenciáját a magimpulzusokéval azonos módon változtattam. Minden esetben 10 körüli értékủ erősítést hoztam létre a kristályon való kétszeri áthaladással. Minden ismétlési frekvencia esetén több mint $2 \cdot 10^{5}$ számú impulzus által létrehozott interferogram került rögzítésre, kivéve $50 \mathrm{~Hz}$ és $100 \mathrm{~Hz}$ frekvenciákon, amikor is a mérés ideje 20 percben lett maximálva a lézerrendszer hosszú távú változásainak kiküszöbölése miatt. A kapott $\varphi_{0}$ zajértékekből a (IV.2.1) és (IV.2.2.) formulákba a mért $d G D / d \varphi_{0}$ együtthatók behelyettesítésével meghatároztam a CEP-zaj hőmérsékleti és mechanikai eredetü értékét a különböző ismétlési frekvenciákon. Ebből az adódott, hogy a mechanikai eredetü járulék $50 \mathrm{~Hz}$ ismétlési frekvencián 0,79 mrad RMS értéket, addig a frekvenciát $1000 \mathrm{~Hz}$-ig növelve már csak 0,39 mrad értéket szolgáltatott, és a két frekvencia között a zaj monoton csökkenést mutatott. Ez egyértelmüen elhanyagolható mértékủ CEP-zaj hozzájárulás egy lézerrendszer esetén. A termikus eredetű CEP-zaj járulék alakulását az ismétlési frekvencia függvényében a IV.2.6. ábra szemlélteti.

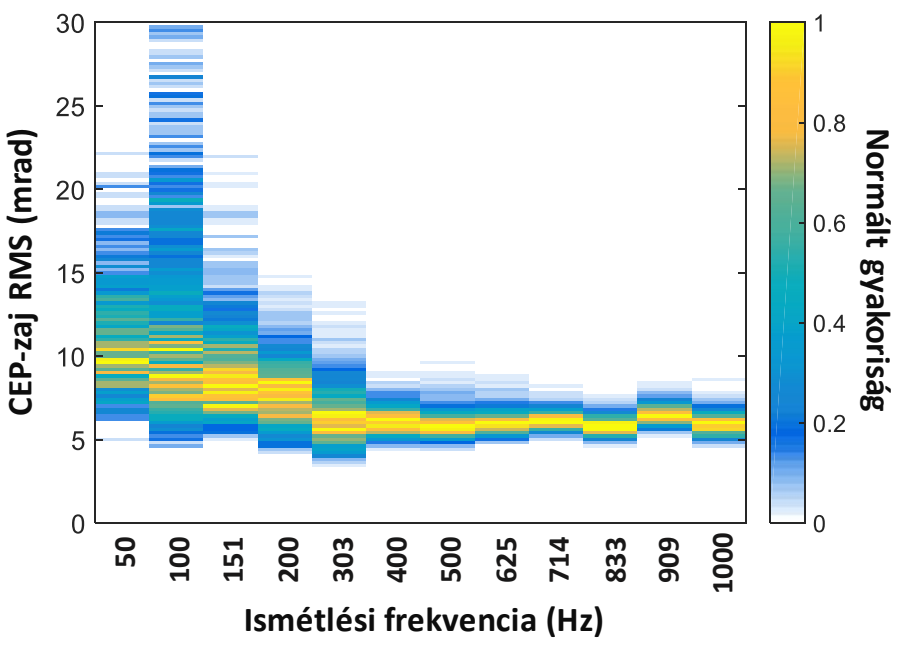

IV.2.6. ábra Termikus eredetü CEP-zaj eloszlás különböző ismétlési frekvenciák esetén. Az erősítő kristályt 10 mJ energiájú pumpaimpulzusok gerjesztették.

Az első fontos eredmény a IV.2.6. ábra alapján, hogy ugyanazon kiértékelést használva, ugyanazon 100 impulzusos periódusú átlagolással, a CEP-zaj eloszlása az alacsonyabb ismétlési frekvenciák irányában egyre kiszélesedik. Továbbá, az $50 \mathrm{~Hz}$ frekvencia felől haladva a nagyobb frekvenciák felé a CEP-zaj értéke csökken egészen $400 \mathrm{~Hz}$-ig, amikor is az ismétlési frekvenciát tovább növelve a zaj értéke gyakorlatilag konstans marad. Mindkét jelenség azzal magyarázható, hogy az ismétlési frekvencia csökkentésével két egymást követő impulzus között egyre nagyobb időintervallum helyezkedik el, amely által egyre több zaj rakódik rá az impulzusokra. Ez mind a mechanikai, mind a termikus eredetü zajra egyúttal érvényes kijelentés. Fontos megjegyezni, hogy az előző fejezetben ismertetett vízhütéses erősítő egyetlen átmenetére $50 \mathrm{~Hz}$-en nagyobb, mintegy 18,7 mrad értékü termikus eredetű CEP-zajt mértem, míg jelen esetben 11,5 mrad körüli értéket kaptam a kétpasszos erősítőre vonatkozólag. Ez a különbség a valóságban nagyobb, hiszen a kriogenikus hütés felhasználása miatt jelentősen megnőtt a 
mérési elrendezés háttérzaja, amely miatt a CEP-zajra vonatkozóan kapott értékek felső becslésnek tekinthetőek. Az eredmények alapján elmondható, hogy a kriogenikus hütés a termikus eredetü CEP-zaj értékét a szobahőmérsékleten mérhető értékhez képest harmadára, vagy annál kisebbre limitálja.

Annak ismeretében, hogy a kriogenikus hütőfej jelentős zajforrást jelentett, a mérés háttérzajának csökkentésével két kísérletet végeztem a pumpálás, azaz az erősítés folyamatának vizsgálatára. A kriogenikus hütőegységet ugyanis a mérés kezdetén kikapcsolva megszüntettem a jelentősebb zajforrást, ugyanakkor a vákuum-eszközöket továbbra is múködtetnem kellett azon okból, hogy a vákuum csökkenése ne okozzon kifagyást a kristály felületén. Az interferométert a két mérés során $20 \mu \mathrm{J}$ energiájú és $200 \mathrm{~Hz}$ ismétlési frekvenciájú impulzusokkal hajtottam meg, amikor is az utóbbi paraméter biztosította, hogy hosszabb mérési időtartam se eredményezzen túl nagy adatsort, de még kellő mennyiségü impulzust mérjünk le. A két mérés egyikét pumpaimpulzusok nélkül, míg a másikat azokkal végeztem (erősítés nélkül és erősítéssel). A mérés megkezdésekor a kriogenikus hütés még aktív volt, megvárva a stabil minimális hőmérséklet beállását, majd ezt követően lekapcsoltam a hűtőfejet. Ezáltal a mérés háttérzaját mintegy 20 mrad RMS értékkel csökkentettem. A kriogenikus hütés kikapcsolásától számítva 80 percen át vettem fel az interferogramok alakulását, amelyeket kiértékelve a két esetre vonatkozólag a IV.2.7. ábra (a) részén látható görbéket kaptam a $\varphi_{0}$ értékére.
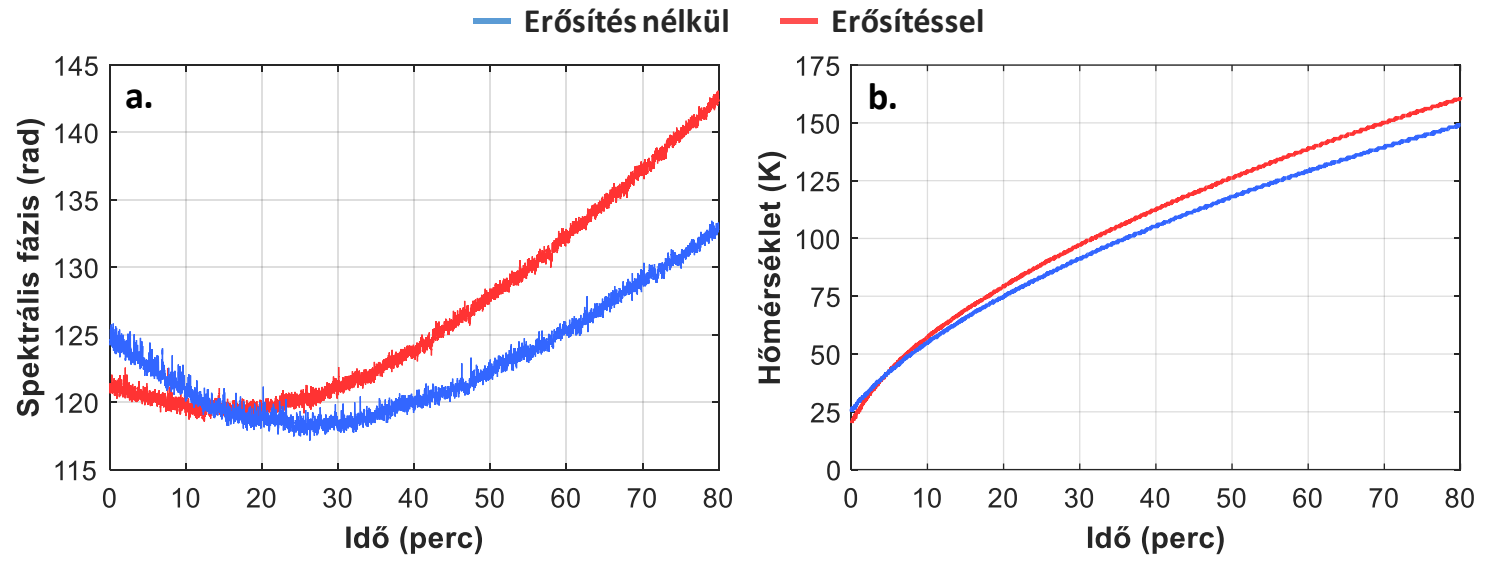

IV.2.7. ábra Spektrális fázis 800 nm-en mért értékének (a) és a kristálytartó hőmérsékletének (b) változása két esetben: erősítés nélkül (kék), illetve erősítés mellett (piros).

A spektrális fázis mérése mellett, azzal időben szinkronizált módon a vákuumkamrában lévő kristálytartó hőmérsékletét is monitoroztam (IV.2.7. ábra, (b) rész), amelyhez egy T-típusú termoelemet használtam fel. A mért adatok alapján a kristálytartó hőmérséklete $25 \mathrm{~K}$ körüli értékről a nem pumpált esetben 149 K-ig, míg pumpált esetben pedig 160 K-ig emelkedett. Mindeközben a IV.2.7. ábra (a) része alapján a $\varphi_{0}$ értéke is jelentősen eltolódott, a pumpaimpulzusok hőterhelésének köszönhetően eltérő módon. Ugyanakkor, ha megfigyeljük a két görbe zajszintjeit, az a két esetben azonosnak mutatkozik, sőt, a hőmérséklet mérés határán belüli megnövekedésével sem változott észrevehetően. Erről akkor bizonyosodhatunk meg, ha összehasonlítjuk a fázis zajának eloszlását a két esetben, amely a IV.2.8. ábrán figyelhető meg. Az erősítés nélkül, illetve erősítéssel mért eloszlások között nincs a mérés hibáján belül észrevehető különbség, azok lefutása mindkét oldalon megegyezik. A IV.2.8. ábra alapján elmondható, hogy a méréshatáron belül nincs szignifikáns hatása a Ti:Sa kristály pumpaimpulzusokkal való felgerjesztésének és energiakicsatolásának a magimpulzusok spektrális fáziszajának eloszlására a vizsgált hőmérsékleti tartományban. Ez azt is jelenti, hogy az általam használt rendkívül stabil pumpalézer impulzusai nem növelték meg mérhető módon a spektrális fázis zaját a populáció inverzió által okozott törésmutató-változás révén. 

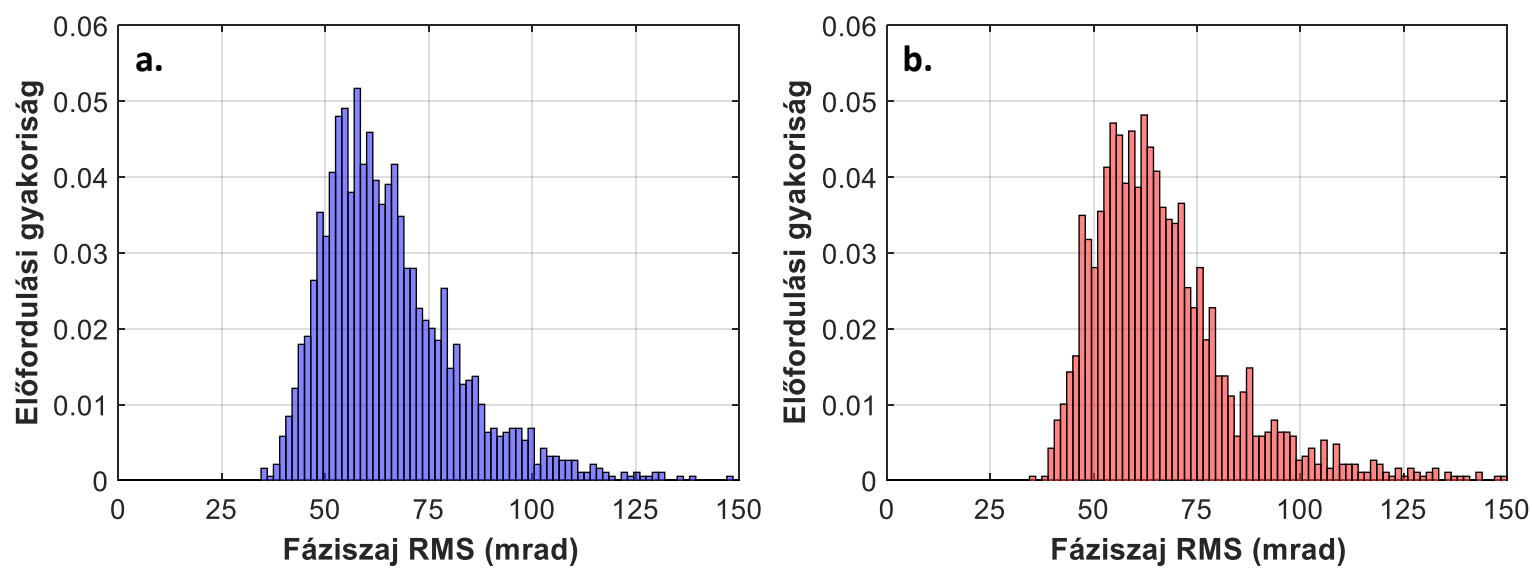

IV.2.8. ábra Spektrális fázis 800 nm-en mért zajának eloszlása erősítés nélkül (kék) és erősítés mellett (piros).

Továbbá, a IV.2.8. ábrán láthatóak alapján a különbözö ismétlési frekvenciákon mért termikus és mechanikai eredetű CEP-zaj értékek felső becsléseknek tekinthetőek.

\section{IV.2.5. Rezgési- és optikai zajspektrumok összehasonlítása}

A mérési elrendezésben jelen lévő mechanikai eredetủ zajforrások beazonosítása alapvető fontosságú ahhoz, hogy megállapítsuk azon zajkomponensek eredetét, amelyek a mérendő impulzusok spektrális fázisára is rárakódnak. Ehhez a IV.2.1. alfejezet végén említett gyorsulásmérőt használtam fel, amit az interferométer közelében elhelyezve, és az interferogramok felvételéhez időben szinkronizálva végeztem méréseket. A gyorsulásmérö $24 \mathrm{kHz}$ frekvenciával mintavételezett, amely a Nyquist-Shannon mintavételezési elv szerint $12 \mathrm{kHz}$-ig enged betekintést a mechanikus rezgések frekvenciaspektrumába. A mérésből kapott adatsorok minden másodpercén FFT-algoritmust végigfuttatva, majd az átlagos spektrális teljesitménysürüséget (Power Spectral Density, PSD) kiszámolva megkaptam a vibrációs spektrumot az interferométer különböző müködési szakaszaira vonatkozólag (IV.2.9. ábra, (a-c) rész). Háttérként (IV.2.9. ábra, (a) rész) az $50 \mathrm{~Hz}$-es elektronikus hálózatból származó zajt, annak felharmonikusait, valamint az asztal és az optikák rezgéseit lehet felfedezni, amelyek közül az utóbbiak a laboratórium padlójából származnak (épületbeli rezgések). A vákuum-rendszerek üzemelése során legfőképpen a turbó pumpa rotorjának forgási frekvenciája $(1500 \mathrm{~Hz})$ és annak felharmonikusai ismerhetőek fel egyértelmüen újabb zajforrásként (IV.2.9. ábra, (b) rész). Végül a kriogenikus hütés müködtetése esetén a teljes zajspektrum megemelkedett, valamint jól kivehetően megjelent egy megközelítőleg 2-5 kHz frekvenciatartományon jelentős zajnövekmény (IV.2.9. ábra, (c) rész), továbbá néhány $1 \mathrm{kHz}$ frekvencia alatti csúcs is kiemelkedett az alapzajhoz képest, amelyek az optomechanikai komponensek sajátfrekvenciái lehetnek.

A megfelelő összehasonlítás elvégzéséhez a zaj spektrális eloszlását az interferogramokból is meghatároztam a következő módon. Az interferométert a teljes lézerrendszeren átküldött oszcillátor impulzusokkal kivilágítva vettem fel az interferogramokat. A jelszint csökkenése miatt a mért nyalábot ráfókuszáltam a spektrométer belépő résére egy $200 \mathrm{~mm}$ fókusztávolságú akromatikus lencse segítségével. A kiolvasás $10 \mathrm{kHz}$ sebességre limitálta a mintavételezést, amely 3,2 s időtartamig történt az NI Max szoftver [173] segítségével. Ebben az esetben a mintavételezési törvény szerint $5 \mathrm{kHz}$ frekvenciáig tudtuk vizsgálni a zaj spektrumát. Számos mérés adatait összesítve, majd a kiértékelésből nyert $\varphi_{0}$ adatsorokat FFT-algoritmussal feldolgozva és PSD-t számolva a IV.2.9. ábra (d-f) részén látható eredményeket kaptam. Megvizsgálva a IV.2.9. ábra (d) részét, az interferométer háttérzajában csúcsok figyelhetőek meg $280 \mathrm{~Hz}$ és $600 \mathrm{~Hz}$ körül. Mindkét csúcs az optomechanikai komponensek 
mechanikai rezonanciáinak köszönhetö, amelyek közül a 600 Hz körüli csúcs a gyorsulásmérővel kapott spektrumban is felfedezhető.
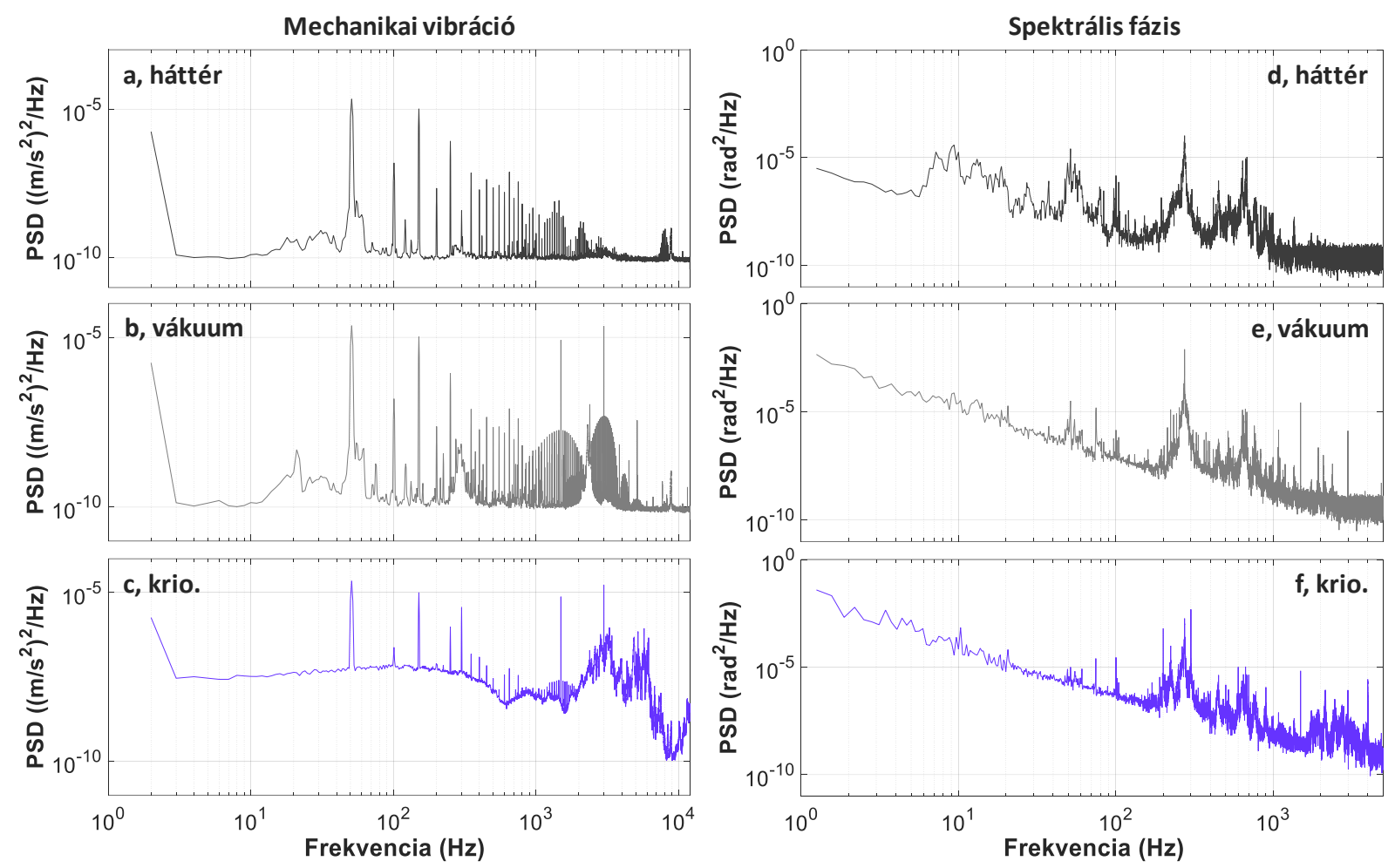

IV.2.9. ábra Spektrális teljesítménysürüség a gyorsulásmérővel rögzített vibrációs jelből, valamint az interferométer kimenetén mért spektrális fázisának zajából FFT-vel nyert adatokból a mérési elrendezés különböző működési szakaszaiban: háttér (a és d), vákuum eszközök működése (b és e), valamint a kriogenikus hütőegység operációja (és vákuum eszközök) során (c és f).

A turbó pumpa felpörgési szakaszában a vezérlő elektronikáján végigkövetett forgási frekvenciaértékek alapján $600 \mathrm{~Hz}$ körül a kísérletek során a teljes elrendezés jól hallhatóan berezonált, amely azt mutatja, hogy ezen a frekvencián az elrendezésnek sajátfrekvenciája van. Az elővákuum-szivattyú működési paramétereit és a turbó pumpa teljes forgási frekvenciáját elérve az interferogramokból nyert zajspektrumban is jól kivehető a turbó forgási frekvenciája, illetve annak felharmonikusai (IV.2.9. ábra, (e) rész). A kriogenikus hủtés müködése során pedig jól beazonosítható a vibrációs spektrumban is látott $2 \mathrm{kHz}$ és $5 \mathrm{kHz}$ közötti szélessávú zaj, amely tehát egyértelmüen a kriogenikus hütőfejben áramló hélium mozgásának tulajdonítható. A IV.2.9. ábra (a-c) részein $10 \mathrm{kHz}$ frekvencia körül látható csúcsok mérési hibák, ugyanis a rezgésmérő érzékenysége ezen a frekvenciatartományon már jelentősen változik.

\section{IV.2.6. Diszkusszió}

A kétpasszos erősítő elrendezésben a Ti:Sa kristály pumpálása nélkül megmérve a magimpulzusok spektrális fázisának zaját az SRI módszerrel megkaptam a vákuum- és kriogenikus hütőeszközök fáziszaj járulékait, amelyeket egy kriogenikus hủtésű erősítő tervezésénél figyelembe kell venni. Mind a vákuum-, mind pedig a hütési technika jelentős mechanikai vibrációt eredményez, amely az erősítőbeli úthosszváltozás révén GD fluktuációkat okoz. Ez többcsatornás erősítés és koherens nyalábkombináció esetén jelentős problémát okozhat. Továbbá, a tervezés során figyelembe kell venni, hogy a minimális hőmérséklet elérése, valamint a nagy átlagteljesítményü pumpálás esetén más-más fázisviszonyok jönnek létre az erősített impulzusokban. 
A hőmérséklet változásából, valamint a mechanikai vibrációkból (levegőben való terjedés hossza) származó CEP-zaj frekvenciafüggése a vízhűtéses erősítés során mért tendenciához hasonló lefutást mutatott. Ugyanakkor, az extrém hatékony kriogenikus hütésnek köszönhetően a termikus eredetủ CEPzaj értéke jelentősen lecsökkent. Az erősítés nélkül és erősítés mellett mért spektrális fáziszajban nem találtam detektálható különbséget, ami azt mutatja, hogy a kriogenikus hütés mellett stabil pumpalézer segítségével a termikus zaj kiküszöbölhetö. A B-integrál értéke a mérés során elhanyagolható mértékủ volt, amit a nyalábméretek megfelelő megválasztása, az alacsony impulzusenergia, valamint a nyújtott impulzusok alkalmazása biztosított.

A $10 \mathrm{kHz}$ frekvenciának megfelelő mintavételezéssel végzett interferometrikus méréseket az optikai elrendezés közelében, az optikai asztalhoz rögzített gyorsulásmérővel kapható rezgésértékek spektrumával hasonlítottam össze. A PSD spektrumokból egyértelmüen felismerhetőek voltak a turbó pumpa rotorjának rotációs frekvenciája, illetve annak felharmonikusai, valamint a kriogenikus hủtő 2 és $5 \mathrm{kHz}$ közötti frekvenciasávban található zajkomponensei. Megfigyelhető volt továbbá, hogy $1 \mathrm{kHz}$ frekvencia alatt több, az optomechanikai komponensek sajátfrekvenciájának megfelelő csúcs is jelentkezett.

A mérések eredményei rámutattak azokra a problémákra, amikkel egy kriogenikus hütésủ, nagy átlagteljesítményü Ti:Sa erősítő megvalósításra során különös figyelmet kell fordítani, hogy a spektrális fázis és a CEP stabilitása ne romoljon le számottevő módon. A jelenleg elérhető fázisstabilizáló rendszerek ugyanis csak limitált sávszélességgel képesek a CEP zajkomponenseinek kompenzálására.

T2.a. Meghatároztam egy kriogenikus hütésü Ti:Sa erősítő spektrális fáziszaját a vákuum-, illetve a hütőrendszerek müködési szakaszainak függvényében. A vákuum-, és a kriogenikus rendszerek spektrális fáziszaj járulékára is 50 mrad RMS körüli értéket kaptam [TP2]. A spektrális fázis zajspektrumát összehasonlítottam az optikai elrendezés mechanikai rezgéseinek frekvenciaeloszlásával, amely alapján azonosítottam a főbb zajforrásokat.

T2.b. Megmértem az erősített impulzusok spektrális fáziszaját az ismétlési frekvencia függvényében. Meghatároztam a CEP termikus és mechanikai eredetü zajának statisztikai eloszlásait. A termikus eredetü CEP-zajra 12 mrad RMS alatti, addig a mechanikai eredetü fáziszajra $1 \mathrm{mrad}$ alatti értékeket kaptam [TP2]. 


\section{IV.3. Ultranagy csúcsteljesítményü impulzusok előállítása Ti:Sa korongerősítőkben}

A CPA rendszerek esetében ismertetett impulzusnyújtás és összenyomás szükséges, de nem elégséges feltétele az impulzusok hatékony erősítésének, a nemlineáris fázistolás minimalizálásának, illetve az optikák sérülésektől való megóvásának. Az impulzusok energiasürüsége szintén fontos paraméter, amelynek az erősítők hatékony müködése esetén a telítődési értékhez közelinek kell lennie. Emellett a lézerrendszer optikái sem terhelhetőek tetszőleges energiasürüségü impulzusokkal, különösen igaz ez az impulzuskompresszorok diffrakciós rácsaira. A CPA és DCPA rendszerekben az erősített impulzusok energiájának jelentős növelése így a pumpa- és az erősítendő nyalábok, valamint a lézerrendszerben található optikák átmérőjének növekedését követeli meg. Ennek köszönhetően a 100 TW körüli csúcsintenzitású impulzusok előállítására alkalmas Ti:Sa alapú erősítő rendszerek esetén már nagy apertúrás ( $>3 \mathrm{~cm}$ átmérő) kristályokat használnak a végerősítő fokozatokban. A megnövekedett apertúra révén a transzverzális irányban jelentősen megnőtt erősítés értéke felülmúlhatja a longitudinális irányút (az átmérő nagyobb a kristály hasznos vastagságánál), amely hatására parazita effektusok léphetnek fel. Amennyiben az ASE aktív közeg peremeiről való visszaverődéseire zárt kör alakul ki, azaz egy rezonátor jön létre a kristályon belül, és az erősítés értéke elegendő a veszteségek leküzdésére, parazita oszcillációkat kapunk. Számos különböző oszcillációs módus jöhet létre az erősítő közegben, amelyek fellépése erősen függ a közeg felületeinek reflexiós együtthatójától [52,174]. Nagy apertúrás kristályok esetén a nagy úthossz miatt a transzverzális irányú parazita oszcillációk (transverse parasitic generation, $\boldsymbol{T P G}$ ) a leginkább káros hatásúak, mivel ezekre különösen nagy erősítés jöhet létre (IV.3.1. ábra, (a) rész). A parazita lézermüködés az erősítő közegből nem kívánt energiakicsatolást eredményez, amely az erősítendő impulzusok által érzékelt térbeli erősítési profilt jelentősen lerontja (IV.3.1. ábra, (c) rész), és ez az effektus a növekvő átmérővel egyre erőteljesebbé válik [175].
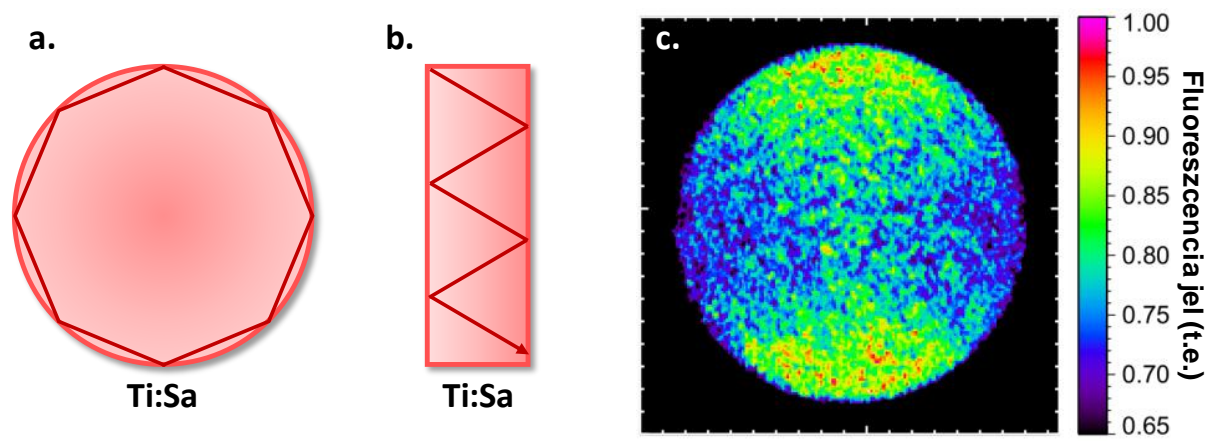

IV.3.1. ábra Gyürü típusú TPG a kristályban, felülnézetből (a). TASE lehetséges útvonala a kristályban, oldalnézetből (b). Mért fluoreszcencia eloszlás egy 52 J energiájú impulzussal pumpált Ti:Sa kristályban, ahol a két szélen horizontális irányban lévő, kékkel jelölt foltok TPG jelenlétére utalnak [176].

A kristály apertúrájának növekedésével a TPG-nél még inkább jelentős korlátozást jelent az erősítésre vonatkozóan a transzverzális irányban fellépö erösitett spontán emisszió (transverse amplified spontaneous emission, $\boldsymbol{T A S E}$ ), amely a kristály peremének reflexióját jelentősen lecsökkentve is fellép (IV.3.1. ábra, (b) rész) [177]. A TASE az erősítő közeg átmérőjének és vastagságának arányától, a longitudinális erősítés értékétől, illetve a felületi normálissal bezárt szögtől függően különböző mértékben csökkenti a tárolt energiát. A parazita effektusok elnyomását a gyakorlatban a kristály pereméröl származó reflexiók csökkentésével oldják meg: az erősítő közeg peremén, annak törésmutatójához illesztett törésmutatójú abszorpciós hatású polimer vagy folyadék elhelyezésével a perem reflexiói jelentősen mérsékelhetőek [175,176,178,179]. A TPG hatás küszöbét ilyen technikával 
hatékonyan lehet megnövelni, azonban a TASE küszöb az apertúra növelésével továbbra is limitálja a kicsatolható impulzusenergia értékét.

A Ti:Sa erősítőkből kicsatolható impulzusenergia, illetve az ismétlési frekvencia növelését a pumpaimpulzusok átlagteljesítményének emelkedése révén limitálja a kristályban fellépő hőterhelés is. Miután a lézeraktív közeg elnyeli a pumpaimpulzusok energiáját, a gerjesztett szintről termikus relaxációval, azaz fononok keletkezésével, továbbá a nem sugárzásos átmenettel a gerjesztett állapotból az alapállapot felé, valamint az alapállapotba való termikus relaxációval hő disszipálódik a kristályban [180]. Az így keletkező hőmérsékletprofil az erősítendő nyaláb hullámfrontját jelentősen torzítja, és termikus lencsét eredményezhet, amely megváltoztatja a nyaláb paramétereit. A termikus lencse által az erősítő közeg, illetve az erősítő, illetve az azt követő alrendszerek optikái sérülhetnek a lokálisan fellépő túl nagy energiasürüség miatt [181].

\section{IV.3.1. Pumpálás közbeni energiakicsatolás korongerősítőben}

A transzverzális lézeraktivitás mérséklésére a gyakorlatban használt törésmutató illesztett abszorberek hatékonysága az erősítő kristály átmérőjének növelésével egyre csökken. Emiatt a nagyenergiájú Ti:Sa erősítőkben a szokványos erősítési folyamat megváltoztatását javasolták [182]. Hagyományos esetben az erősítő kristályt felgerjesztjük a felső, lézeraktív energiaszintre egy pumpaimpulzus abszorpciója révén, az erősítendő impulzus első átmenete előtt. Ezt követően több passz segítségével ürítjük ki a közegben tárolt energiát. Ez a folyamat néhány $\mathrm{cm}$ apertúrájú erősítő kristályokig hatékonyan alkalmazható, azonban amint a kristály apertúrája meghaladja a vastagságát, a parazita effektusok megjelenésével leromlik az erősítő hatékonysága. A pumpálás és az energiakicsatolás időzítésének újrahangolásával a probléma jelentősen mérsékelhető: az erősítő közeget elsőként felpumpáljuk a TPG vagy TASE által meghatározott küszöb populáció inverzióig, majd energiát csatolunk ki az erősítendő impulzus első átmenetével, amit követően tovább pumpáljuk a közeget ismét a parazita küszöbig, majd a következő erősítendő impulzus átmenettel energiát csatolunk ki, és így tovább (IV.3.2. ábra). A módszert pumpálás közbeni energiakicsatolásnak (extraction during pumping, EDP) nevezzük [177,182].

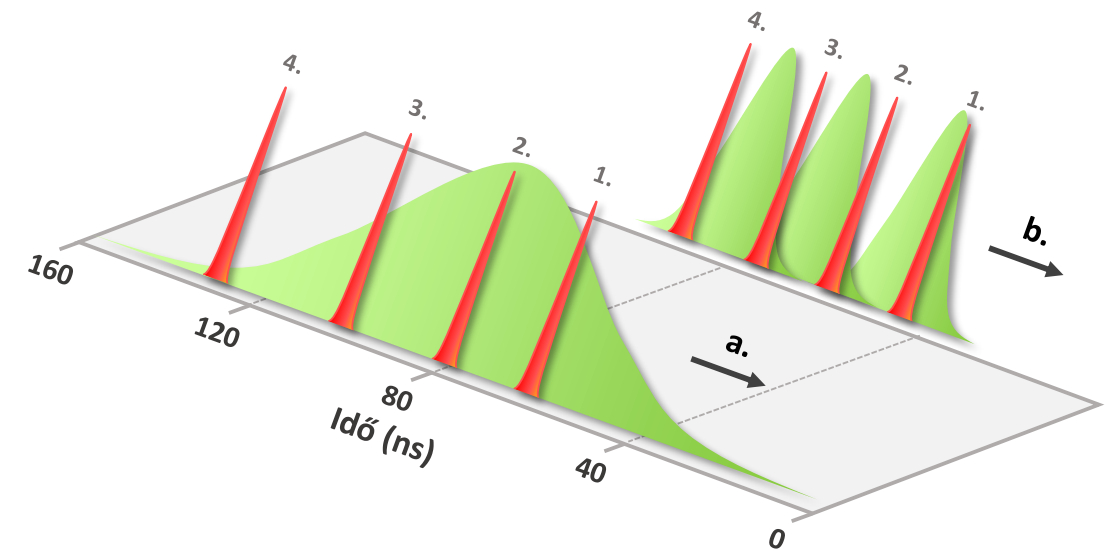

IV.3.2. ábra EDP típusú erősítés folyamatának idődiagramja két esetre, amikor egy hosszabb ( 100 ns félértékszélesség) pumpaimpulzus (a), vagy több rövidebb ( 5-40 ns félértékszélesség) pumpaimpulzus gerjeszti az erősítő közeget. Az erősítendő impulzusok közegen való áthaladásának optimális időzítését a parazita küszöb elérése határozza meg.

A pumpaenergia konvencionálistól eltérő időbeli megosztása azt eredményezi, hogy a TPG és a TASE nem tud jelentős mértékben megnövekedni az egyes erősítendő impulzus átmenetek között, amely így megakadályozza a populáció inverzió nem kívánt lecsökkenését a kristály pumpált térfogatában. Az 
EDP módszer hagyományos, törésmutató illesztett abszorber peremen való kombinált használatával nagymértékben csökkenthető a TPG és a TASE hatása [12,183].

Számos alkalmazáshoz a nagyenergiájú impulzusok 100 TW - PW csúcsteljesítménye mellett a jelenleg elérhetőnél jóval nagyobb ismétlési frekvencia is szükséges. Ez azt jelenti, hogy mind az erősített, mind pedig a pumpaimpulzusok átlagteljesítménye néhányszor $100 \mathrm{~W}$-tól a néhány kW értékig is megemelkedhet. A legnagyobb problémát az utóbbi jelenti, ugyanis az erősítő közeg hőterhelése már néhányszor $10 \mathrm{~W}$ esetén is jelentős hullámfront torzulásokat okozhat. A megnövekedett hőterhelést a konvencionális, nyaláb irányára nézve transzverzális hőkicsatolás, vagyis az általában használt hengeres geometriájú Ti:Sa kristályok palástja mentén történő hütés nem képes kompenzálni. A II.2.6. alfejezetben ismertetett koronglézerek esetén alkalmazott geometria viszont éppen a nagy átlagteljesítményű lézermüködés során fellépő hőterhelés kezelésére lett kifejlesztve. A koronglézer geometriát mindeddig jellemzően csak az Yb-mal adalékolt erősítő közegek esetén alkalmazták oszcillátorokban és erősítőkben. A Ti:Sa $35 \mathrm{~W} /(\mathrm{m} \cdot \mathrm{K})$ szobahőmérsékleti hővezetési tényezője és $220 \mathrm{~nm}$ körüli emissziós sávszélessége a koronglézerekben leginkább használt Yb:YAG kristály $11 \mathrm{~W} /(\mathrm{m} \cdot \mathrm{K})$ hővezetéséhez és $11 \mathrm{~nm}$ széles emissziós sávjához képest jelentős javulást eredményezhet egy koronglézeres elrendezésben alkalmazva. A Ti:Sa koronglézer geometriában való alkalmazásával potenciálisan ultranagy csúcsintenzitású impulzusokat állíthatunk elő, méghozzá korábban elérhetetlen átlagteljesítmény mellett.

Fontos azonban, hogy a szóban forgó 100 TW csúcsteljesítményủ rendszerek esetén szükséges 3$5 \mathrm{~cm}$ kristály apertúrára nézve a korong geometriával éppen a IV.3.1. alfejezetben említett TPG és TASE limitációk lépnének fel. Emiatt a korong geometria előnyének kihasználásához szükség van a transzverzális lézeraktivitás egyidejü mérséklésére is. Ennek fényében kutatótársaimmal az EDP időzítési eljárás és a koronglézer geometria egyidejü alkalmazását javasoltuk a 100 TW és annál nagyobb csúcsteljesítményt biztosító Ti:Sa végerősítők esetére. Egy lehetséges EDP-korongerösitő (extraction during pumping - thin disk, EDP-TD) lézerfejének egyszerüsített képét a IV.3.3. ábrán vázoltam fel.

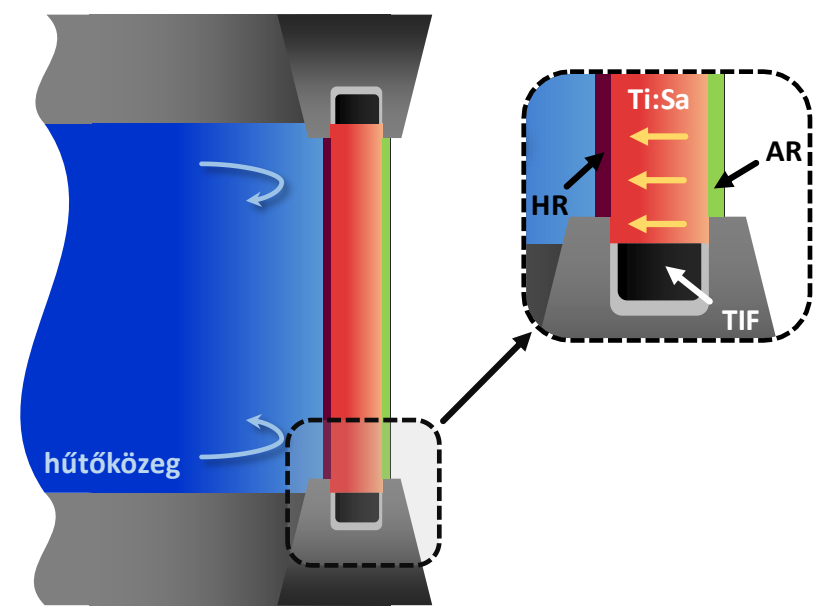

IV.3.3. ábra Egy lehetséges EDP-TD erősítő modul sematikus képe. A sárga nyilak a hőterjedés irányát jelölik. Belenagyítva az ábra jobb alsó részébe, HR nagy reflexiójú, AR pedig alacsony reflexiójú dielektrikum réteget jelöl a pumpa- és az erősítendő jel hullámhosszaira optimalizálva, és TIF törésmutató illesztett abszorber folyadék a kristály peremén.

A IV.3.3. ábrán látható erősitő modul esetén a Ti:Sa korong első oldala AR, míg hátsó oldala HR bevonattal van ellátva a pumpa $(532 \mathrm{~nm})$ illetve az erősítendő impulzus (700-900 nm) hullámhossztartományára. Ennek megfelelően az erősítő közeg aktív tükörként funkcionál: mind a 
pumpa, mind pedig az erősítendő impulzusok áthaladva a kristályon visszaverődnek a hátsó felület HR rétegéről. Az így kapható erősítő elrendezés geometriája egy hagyományos korongerősítőhöz képest jelentősen egyszerübb lehet. Ennek oka, hogy egyrészt a Ti:Sa korong a több $10 \mathrm{~mm}$-es átméröje miatt akár több mm-es vastagsággal is rendelkezhet, valamint a kristály abszorpciós hatáskeresztmetszete jóval nagyobb a szokásos koronglézerek aktív közegeinél mérhetőknél. A pumpaimpulzusok kívánt mértékü abszorpciójának elérése - amely jellemzően 90-95\% - ebből következően csupán néhány átmenettel megoldható, szemben az Yb:YAG koronglézereknél megszokott néhányszor tíz átmenettel. Az elrendezés egyszerüsödésének másik oka, hogy a Ti:Sa erősítési hatáskeresztmetszete is jóval nagyobb a tipikus koronglézer közegekénél, így a nagyobb egy passzban kialakuló erősítés miatt elegendő 4-6 átmenet megvalósítása a tervezett energiakicsatolás eléréséhez. A IV.3.3. ábrán észrevehető, hogy a kristály peremén helyet kapott a törésmutató-illesztett abszorber is, amely jelenleg folyadék halmazállapotban áll rendelkezésre, ezért a kristály szélénél a befogatásban kialakított csatornában kaphat helyet.

\section{IV.3.2. EDP-TD erősítő termikus modellje}

Az EDP-TD módszer konvencionális erősítőkkel szembeni előnyeinek demonstrációjához egy kétdimenziós numerikus modellt építettem végeselem módszerrel (finite element method, FEM), a COMSOL Multiphysics [184] szoftver segítségével. A modell felhasználásával a Ti:Sa kristályban a pumpaimpulzusok abszorpciója által kialakuló stacionárius hőmérséklet-eloszlást határoztam meg. Tekintettel arra, hogy a legkorszerübb PW osztályú Ti:Sa erősítők esetén vízhütéssel 1-10 Hz ismétlési frekvencia érhető el, érdemes az EDP-TD módszert ilyen paraméterekkel rendelkező konvencionális erősítőkkel összevetni. Ehhez egy 2 PW csúcsteljesítményü impulzusok elöállítására alkalmas, $120 \mathrm{~J}$ energiával $10 \mathrm{~Hz}$ ismétlési frekvencián pumpált végerősítő fokozatot vizsgáltam, amit konvencionális és korong geometriájú hütéssel is szimuláltam. A modell csak a Ti:Sa kristályt, és a befogatást tartalmazta. A hütött felületen konstans hőmérsékleti peremfeltételt vettem fel, jelentősen leegyszerüsítve a termikus probléma megoldását. Tekintettel a hengeres szimmetriára, a hőmérséklet eloszlását csupán a kristály felére kellett kiszámolnom. A hütés hőmérsékletét mindkét esetben a vízhütéses lézerek esetén tipikus $15{ }^{\circ} \mathrm{C}$-ra állítottam be. A pumpaimpulzusok $95 \%$-os abszorpcióját a konvencionális erősítő esetén kétoldali pumpálással egy passzban, addig a EDP-TD erősítő esetén a IV.3.3. ábrán felvázolt aktív tükörként funkcionáló elrendezés szerint, egyoldali pumpálással és két átmenettel (effektíve négy) értem el. A pumpaimpulzusok hőterhelését a kristályban a Függelék XI.1. alfejezetében található (XI.8) egyenletek felhasználásával adtam meg. Ehhez a konvencionális erősítő esetén egy $3 \mathrm{~cm}$ vastag és $12 \mathrm{~cm}$ átmérőjü, addig az EDP-TD erősítőre egy $1 \mathrm{~cm}$ vastag és $11 \mathrm{~cm}$ átmérőjü kristályt vettem fel a modellben. A Ti:Sa kristály hőmérsékletfüggő paramétereit a COMSOL Material Library [185] szoftverrészlet zafír anyagra vonatkozó értékeinek felhasználásával adtam meg. A szoftver által tartalmazott paramétereket összevetettem az irodalomban foglaltakkal, és meggyőződtem róla, hogy azok a modellezett hőmérséklet-tartományra helyesek [75,186,187].

A konvencionális erősítő kristályának hủtött pereme a IV.3.4. ábra (a) részének jobb oldala volt, amely az erősítő közeg oldalsó felületét jelentette. Továbbá, a kristály befogatását is figyelembe vettem, amely az $50 \mathrm{~mm}$ radiális koordinátától eredményez változást a hőmérséklet alakulásában (IV.3.4. ábra, (c) rész). Az EDP-TD erősítő esetén a IV.3.4. ábra (b) részén a felső oldal volt a hütött perem. A IV.3.4. ábra (a) és (b) részén látható kétdimenziós hőmérséklet-eloszlásokról leolvasható, hogy a csúcshőmérséklet, valamint a radiális irányú hőmérséklet-gradiens értéke is rendkívül eltérő a két esetre. Utóbbi még inkább egyértelmüvé válik a IV.3.4. ábra (c) részén vizualizált görbék alapján. A 
pumpaimpulzusok abszorpciójából származó hőterhelés esetén az erősítés hatásfokát is figyelembe vettem, amely a konvencionális erősítőben 40\%, addig az EDP-TD modul esetén 60\%-nak volt feltételezve. A konvencionális erősítés esetén a kristály oldalsó felületén való hütés jól láthatóan jelentős hőmérséklet-különbséget eredményez a közeg centruma és szélei között, amely jelentős termikus lencsét eredményezne egy valódi erősítőben már egyszeri áthaladásra is. Ezt lehetséges úgy csökkenteni, hogy egy erősítő elrendezésben két lézerfejet helyeznek el, amely révén két kristály között oszlik meg a nagy fütőteljesítmény.

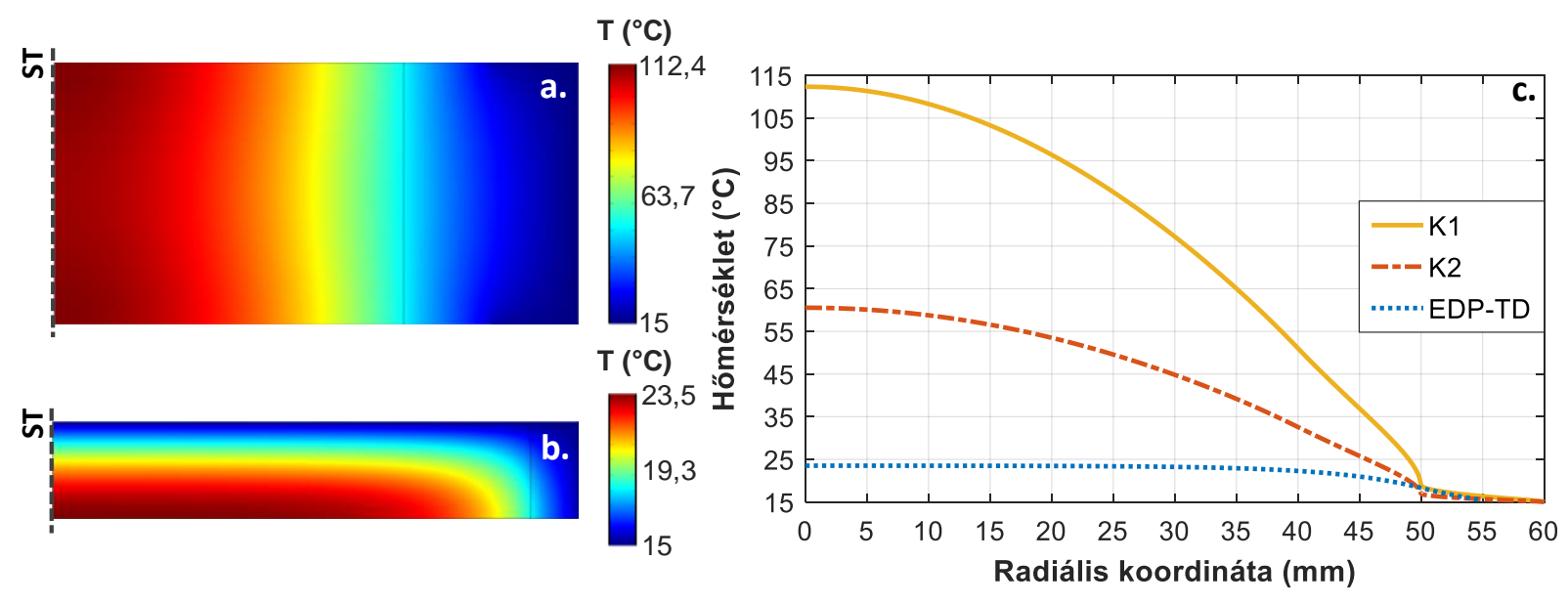

IV.3.4. ábra Kétdimenziós hőmérséklet-eloszlás a konvencionális erősítő (a), és az EDP-TD erősítő kristályában (b), ahol ST szimmetriatengelyt jelöl. Összehasonlítás az első felület hőmérsékletének radiális függésére az (a, K1), (b, EDP-TD), és a két lézerfejet tartalmazó konvencionális erősítőre (K2) vonatkozóan.

Kiszámolva a hőmérséklet-eloszlást két azonos méretü erősítő közeget feltételezve az elrendezésben, kétoldali pumpálás mellett még mindig $60,5^{\circ} \mathrm{C}$ hömérséklet adódik mindkét Ti:Sa kristály centrális részén (IV.3.4. ábra, (c) rész, K2 görbe), amennyiben a pumpaenergia és az erősítés azonos a két kristályban. Összehasonlítva az egy-, és két lézerfejet tartalmazó, konvencionális erősítők hőmérsékleti gradienseit az EDP-TD módszerrel és azonos pumpaenergiával kaphatóval, nagy különbséget tapasztaltam. Míg a konvencionális erősítőknél $93,5^{\circ} \mathrm{C}$ és $43,6^{\circ} \mathrm{C}$ a különbség az egy és két erősítő fejet tartalmazó eseteknél, addig az EDP-TD erősítőben ez az érték 5,2 ${ }^{\circ} \mathrm{C}$. Érdemes megemlíteni, hogy az imént ismertetett eredmények elérése során alkalmazott hőmérsékleti peremfeltétel a hütés ideális esete. Ugyanakkor, a két erősítő koncepció közötti különbségek világosan demonstrálják az TD módszer előnyeit a hủtés szempontjából.

\section{IV.3.3. EDP-TD végerősítő kísérleti elrendezése}

Az EDP-TD erősítő müködésének kísérleti demonstrációjához a Max-Born-Institut für Nichtlineare Optik und Kurzzeitspektroskopie im Forschungsverbund Berlin e.V. intézetben [188] kutatótársaimmal felépítettünk egy multipasszos erősítő elrendezést, és karakterizáltuk annak müködési paramétereit. Az említett intézet két nagyintenzitású lézerrendszer csatornának adott otthont, amelyek közös frontenddel (IV.3.5. ábra, „Frontend” rész) rendelkeztek. Az egyik csatorna egy Ti:Sa alapú, 70 TW (2,5 J, 35 fs) csúcsteljesítményü impulzusok előállítását lehetővé tevő, egyedi építésű rendszer volt [189]. Ezzel szemben a másik csatorna egy kommerciális erősítő rendszer (Amplitude Technologies, [190]) volt 100 TW csúcsteljesítményű impulzusokkal. Mivel a kísérlet során az utóbbi csatornát használtuk fel, annak felépítésével fogok részletesen foglalkozni a következő bekezdésben.

A 100 TW csúcsteljesítményű rendszer egy Ti:Sa alapú DCPA rendszer volt 2,5 J energiával és 25 fs impulzushosszal a kimenetén. A frontend 25 fs hosszúságú, 1,2 mJ energiájú impulzusokat biztosított 
$10^{9}$ impulzuskontraszt (elöimpulzus-kontraszt a föimpulzushoz képest) és $10 \mathrm{~Hz}$ ismétlési frekvencia mellett. Az így keletkező impulzusokon időszürést végeztek el XPW keltés felhasználásával egy vákuum kamrában elhelyezett elrendezés segítségével [191]. Ennek hatására az impulzusok kontrasztja $10^{12}$ értékre nőtt, míg energiájuk a kezdeti értékről töredékére csökkent. Az XPW fokozatban időszürt impulzusokat 400 ps hosszúságúra nyújtották egy diffrakciós rácsokon alapuló elrendezésben (IV.3.5. ábra, „TW nyújtó” rész), majd több Ti:Sa alapú erősítőben növelték meg az impulzusenergiát. A végerősítő előtt a magimpulzusok energiája elérte az $500 \mathrm{~mJ}$-t. A $500 \mathrm{~mJ}$ energiájú magimpulzusok a kriogenikus hütésủ végerősítőn végig haladva $4 \mathrm{~J}$ energiát értek el, amit a szintén rácsos, vákuumban elhelyezett impulzuskompresszor 25 fs hosszúságúra nyomott össze 2,5 J kimeneti impulzusenergia mellett, amely 100 TW csúcsteljesítménynek felelt meg (IV.3.5. ábra, elhalványított rész).

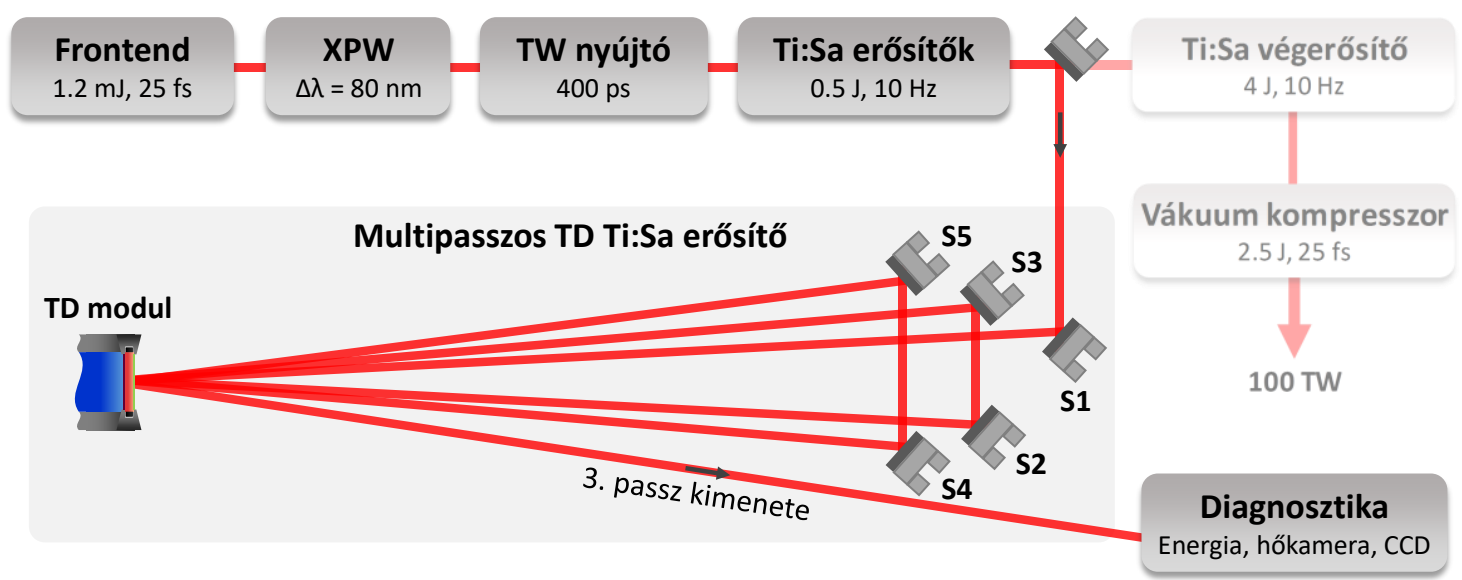

IV.3.5. ábra 100 TW csúcsteljesítményü lézerrendszer kísérletben felhasznált része, illetve a kísérleti EDP-TD erősítő optikai elrendezése. Elhalványítva ábrázoltam a kísérlet során kikerült végerősítőt, valamint az impulzuskompresszort.

A kísérlet során a végerősítőt áthidalva a magimpulzusokat az EDP-TD erősítő elrendezésbe küldtük. Az erősítendő impulzusokra egy hárompasszos elrendezést valósítottunk meg, amely a kristály hátoldali reflexiója révén hat passznak felelt meg. A teljes elrendezést az erősítendő impulzusokra vonatkozóan a IV.3.5. ábra alsó része szemlélteti.

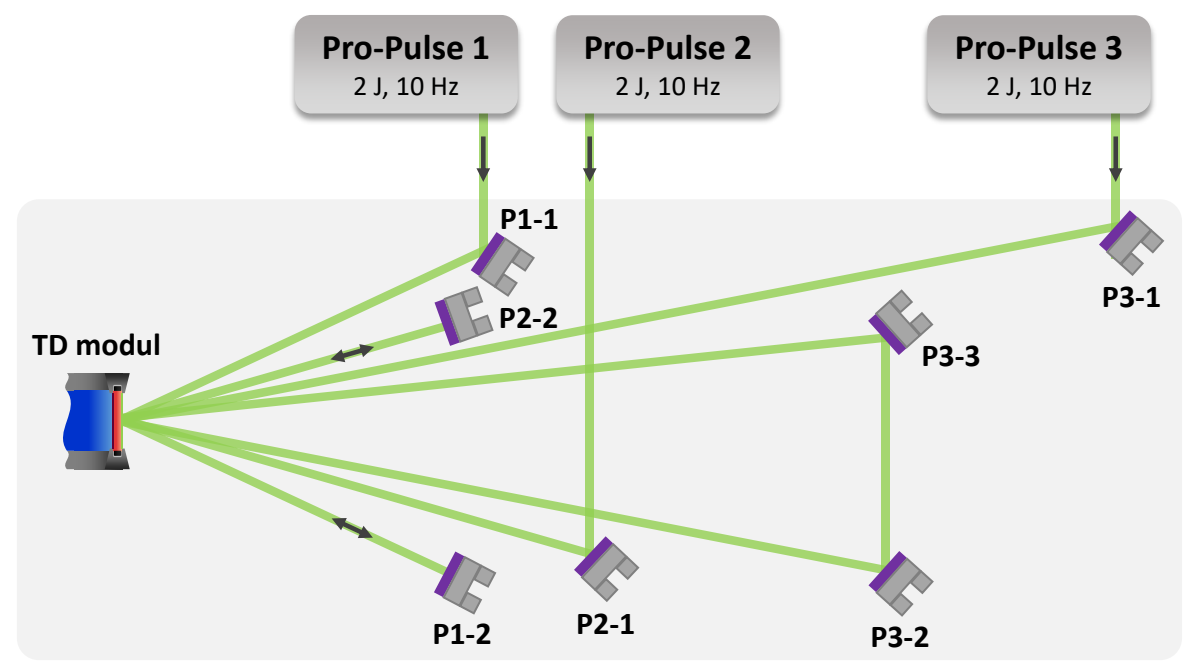

IV.3.6. ábra EDP-TD erősítő pumpálásának optikai elrendezése. Mindhárom pumpalézer nyalábja kétszer verődött vissza a kristály hátsó felületéről, amely effektíve 4 passznak felelt meg az aktív közegben. 
Az eredeti végerősítőt négy Pro-Pulse (Amplitude Technologies) [190] típusú pumpalézer hajtotta meg $10 \mathrm{~Hz}$ ismétlési frekvencián, egyenként $2 \mathrm{~J}$ energiájú és 6,8 ns időbeli félértékszélességü impulzusokkal $532 \mathrm{~nm}$ hullámhosszon. Ezen pumpalézerek közül a kísérlet ideje alatt az egyik nem volt használható állapotban, így az eredetileg $8 \mathrm{~J}$ teljes pumpaenergiából $6 \mathrm{~J}$ energiát tudtuk felhasználni. Mindhárom pumpalézer által biztosított nyaláb esetén két átmenetet alakítottunk ki a Ti:Sa kristályon keresztül, amely effektíve négy passznak felel meg, mivel az impulzusok a kristály hátsó felületén lévő HR rétegről visszaverődnek (IV.3.6. ábra). Az erősített impulzusok energiáját egy nagy csúcsteljesítményü impulzusok detektálására alkalmas (Coherent, PM30V1) energiamérővel mértük. Ezen felül a kristályt egy CCD kamera segítségével monitoroztuk, amely a pumpaimpulzusokkal történő gerjesztés hatására kialakuló fluoreszcencia profil megfigyelését tette lehetővé. Továbbá az erősítendő impulzusokkal való energiakicsatolást az egyes passzokban a kristály közelében elhelyezett gyors fotodióda (Thorlabs, DET10A/M) segítségével, a fluoreszcencia időbeli lefutásának mérésével vizsgáltuk. A kristályban felhalmozódó hő hatására bekövetkező hőmérséklet-változás monitorozására egy hőkamerát (MicroEpsilon, TIM-160 [177]) használtunk fel. Mind a pumpa-, mind pedig az erősítendő impulzusok esetén a passzok kialakítása során a hagyományos Ti:Sa erősítőkre is jellemző, minimális szögek kialakítására törekedtünk a megfelelő térbeli átfedés biztosítása érdekében. A mag- és a pumpaimpulzusok átméröje 24 mm-re lett beállítva a kristály elülső felületén, amely a közeg teljes vastagságában állandónak volt tekinthetö.

A kísérlethez egy, az ELI-ALPS mérnökei által megvalósított TD hütő egységet használtunk fel, amelybe egy $35 \mathrm{~mm}$ átméröjü és $3 \mathrm{~mm}$ vastagságú Ti:Sa korongot fogattunk be. A kristály elülső felületére AR, míg a hátsó felületére pedig HR dielektrikum réteg került a pumpa- (532 nm) és a magimpulzusok (800 nm körül) hullámhosszaira optimalizálva. A kristály abszorpciós együtthatója a pumpaimpulzusok hullámhosszára vonatkozóan $2 \mathrm{~cm}^{-1}$ értékü volt. A felhasznált TD modul prototípusának háromdimenziós képét a IV.3.7. ábra (a) része szemlélteti.

a.

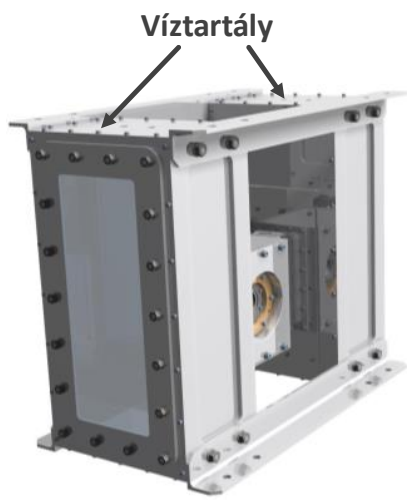

b.

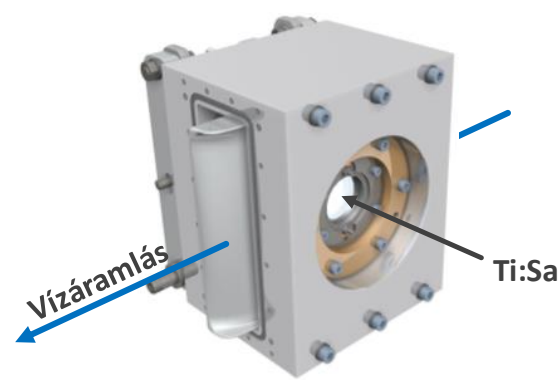

IV.3.7. ábra TD modul prototípus elölről (a), illetve központi rész kialakítása (b).

A központi egységhez (IV.3.7. ábra, (b) rész) két víztartály csatlakozik, amelyek felső részénél lett kialakítva a hütővíz be- és kivezetése. A bemenetre nyomáscsökkentő szelep lett felszerelve, hogy a folyadékáramlás sebességét a nyomás révén szabályozni lehessen. Továbbá, a kristállyal közvetlen kapcsolatban lévő áramlási csatorna vastagságát egy külső csavar segítségével tudtuk állítani. A kristály befogatásánál egy kisméretủ kamra lett kialakítva a korong palástja mentén, amely egy M-sorozatú (Cargille Labs) törésmutató-illesztett folyadékban (TIF, 1,76 értékü törésmutató $800 \mathrm{~nm}$ hullámhosszon) feloldott IR140 típusú (Exciton) abszorber festékkel lett feltöltve (IV.3.8. ábra). A Ti:Sa kristály hátsó felületével érintkező hűtőcsatorna részben a hütővíz áramlási sebességét a rendelkezésre álló temperáló berendezés, valamint a TD modul által megengedett víznyomás határozta meg. Ennek 
méréséhez a hütőberendezés beindítását követően a közvetlenül a kristály mögött folyásirányban elhaladó buborékok mozgását 60 fps gyorsaságú CCD kamerával rögzítettük.

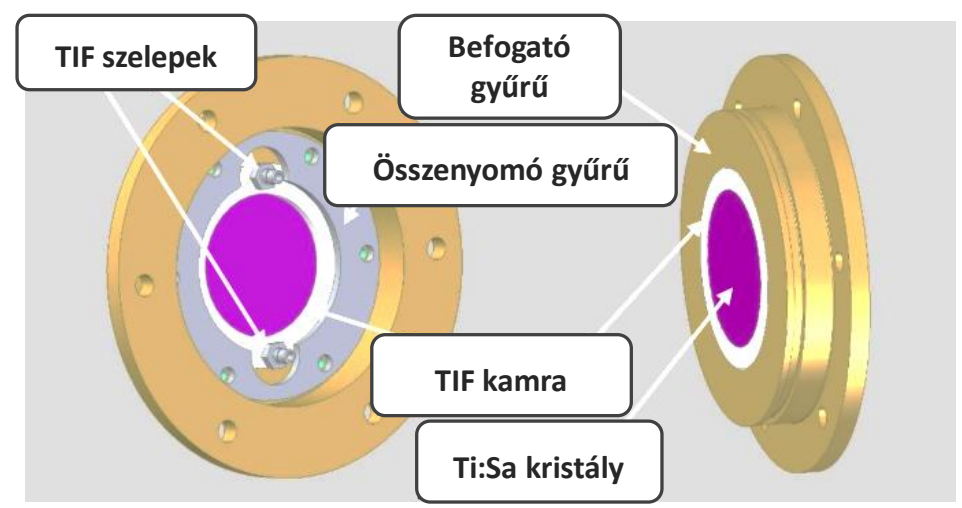

IV.3.8. ábra Ti:Sa kristály befogatásának és az abszorber elhelyezésének képe.

A buborékok mozgási sebességéből az áramlás sebességét a Ti:Sa kristály mögött $0,35 \mathrm{~m} / \mathrm{s}$ értékünek becsültük meg. A mért sebesség, valamint a csatorna geometriája alapján az áramlás lamináris volt.

\section{IV.3.4. Egylövéses erősítési kísérletek}

A IV.3.5. ábrán felvázolt erősítő elrendezés felépítését követően annak tesztelése következett egylövéses üzemmódban. Ehhez a Ti:Sa kristálytól $40 \mathrm{~cm}$ távolságra lévő gyors fotodióda (Thorlabs, DET10A/M) segítségével a fluoreszcencia időbeli lefutását vizsgáltam meg pumpálás és energiakicsatolás során. A kristályt két pumpalézerből származó egy-egy impulzus kétszeri átmenetével gerjesztve a magimpulzus becsatolása nélkül a IV.3.9. ábra (a) részén látható oszcillogramot mértem. A mért jelen egyértelmüen kivehető, hogy bár a kristály peremén az abszorber elnyomja a TPG folyamat egy részét, az EDP módszer nélkül 90 ns körül mégis jelentős parazita oszcilláció mérhető. A teljes mért abszorbeált pumpaenergia ekkor 3,4 J értékü volt. Mérve a kristályból származó szóródott fluoreszcenciát abban az esetben, amikor az abszorbeált pumpaenergiát három magimpulzus átmenettel csatoljuk ki, a IV.3.9. ábra (b) részén látható oszcillogramot kaptam. Ekkor a 110 ns-nál beinduló TPG folyamatot az első magimpulzus átmenet elnyomja, mivel energiát csatolunk ki az erősítés által (IV.3.9. ábra, (b) rész, 1. jelölés).
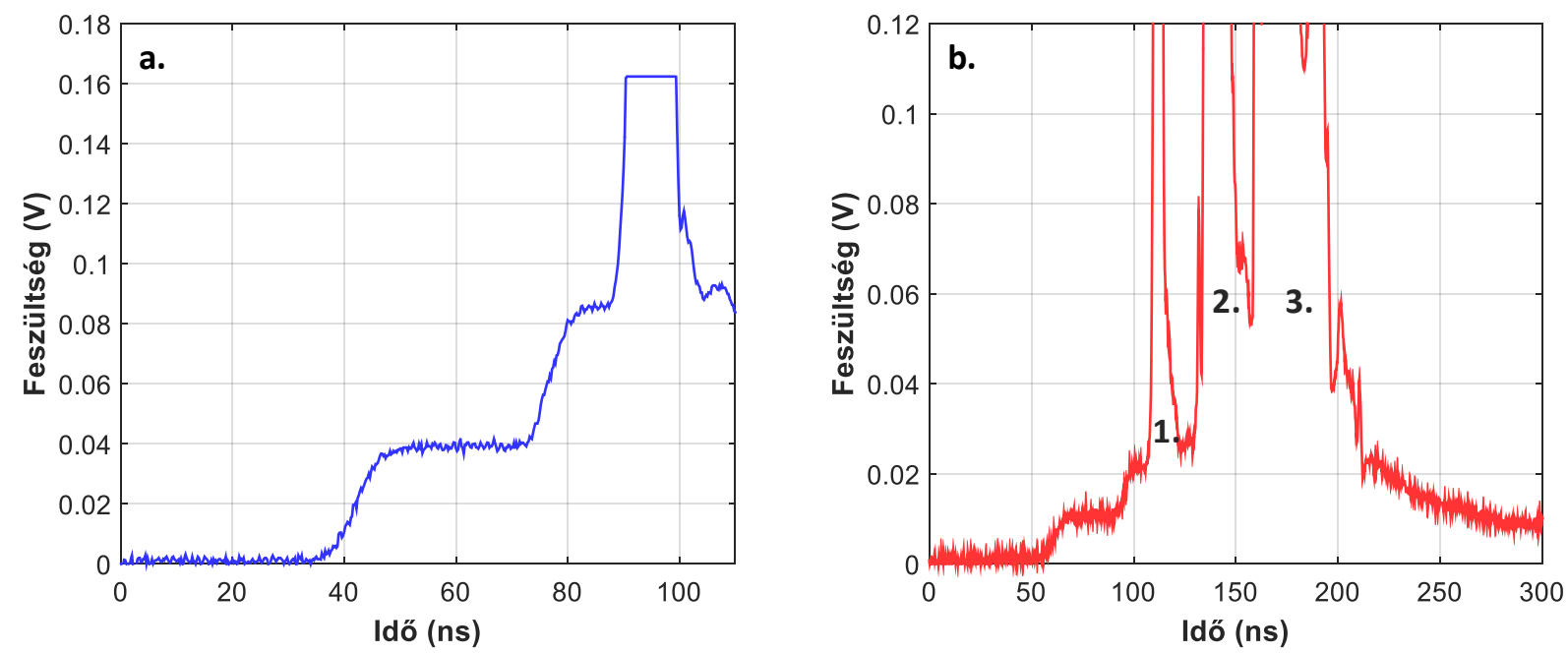

IV.3.9. ábra Ti:Sa kristály szórt fluoreszcenciájának oszcillogramjai: TPG két pumpaimpulzus kétszeri átmenetének hatására, ahol 3,4 J pumpaenergia abszorbeálódott (a), illetve pumpálás közben három magimpulzus átmenet esetén felvett jel (b). 
A kristályt ezt követően egy újabb pumpaimpulzus átmenete során bekövetkező abszorpcióval tovább gerjesztettem, mivel a TPG limit alá kerültünk az első magimpulzus átmenet során bekövetkező erősítéssel. Az ekkor fellépő TPG aktivitást a második magimpulzus átmenet mérsékelte (IV.3.9. ábra, (b) rész, 2. jelölés), majd végül a harmadik átmenet során is hasonlót mértem (IV.3.9. ábra, (b) rész, 3. jelölés).

Az optimális erősítés eléréséhez az erősítő minden passzának finom állítását kellett elvégezni, miközben az egyes pumpalézerekből származó impulzusok időzítését is precízen kellett hangolni. Mindhárom pumpalézer magimpulzusokhoz való szinkronizálását elektronikus úton értük el. A passzonkénti időzítést a pumpanyaláb tükreinek pozíciója határozta meg. Az első átmenet után a magimpulzus energiája $1 \mathrm{~J}$ értékre nőtt, amely a bemenethez képest kettes erősítésnek felel meg. A IV.3.6. ábrán alkalmazott jelöléseket követve, a 1. és a 3. pumpalézer impulzusait felhasználva gerjesztjük először az erősítő közeget. A 2. pumpalézer impulzusait a második és a harmadik magimpulzus átmenet közé lettek időzítve.
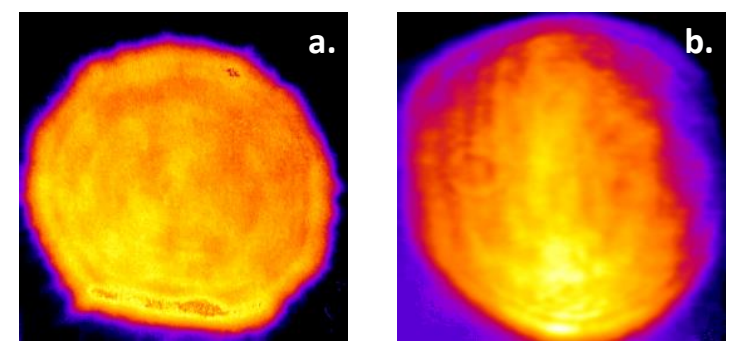

IV.3.10. ábra Közeli térben felvett tipikus nyalábprofilok a pumpaimpulzusok esetében (a), valamint a magimpulzusok harmadik passza után (b).

Mindhárom pumpalézer nyalábjainak kétszeri, a Ti:Sa kristály hátoldaláról való reflexióval $85 \%$ abszorpciót értük el, amely révén $5 \mathrm{~J}$ pumpaenergia nyelődött el az erősítő közegben. A magimpulzusok három átmenetével (effektíve 6) az erősítő kimenetén 2,6 J energiát sikerült kicsatolni. Az optikaioptikai hatásfok az erősítés során a magimpulzusok $0,5 \mathrm{~J}$ bemeneti energiáját figyelembe véve ez alapján 42\%-ra tehető. Fontos megemlíteni, hogy az Yb:YAG korongerősítő elrendezésekben a kívánt erősítést jellemzően több tíz passz segítségével érik el, addig jelen esetben elegendő volt mindössze három passzt kialakítani. Ezt a Ti:Sa kristály jóval nagyobb vastagsága, magasabb abszorpciója illetve emissziós hatáskeresztmetszete tette lehetővé. Egy CCD kamera segítségével mind a pumpa, mind pedig a magimpulzusok tipikus közeli térbeli nyalábprofilját rögzítve a III.3.10. ábrán látható nyalábkeresztmetszeteket kaptuk. A magimpulzusok nyalábprofiljában felfedezhető flat-top profiltól való eltérést a kísérlet során felhasznált Ti:Sa kristály hengeres hátsó felülete, valamint a pumpaimpulzusok profiljában lévő intenzitásgyürük erősítési profilra gyakorolt hatása okozta. $\mathrm{Az}$ előbbi effektus a kristály vágására és polírozására vonatkozó minőségi probléma eredménye.

\section{IV.3.5. $10 \mathrm{~Hz}$-es pumpálás termikus hatása}

Az erősítés optimális müködésének kimutatása mellett a kísérlet másik fő célja a korong geometria hűtési hatásfokának szokásos erősítőkhöz képesti jelentős javulásának kimutatása volt. A hőkicsatolás hatékonyságának vizsgálatához a már említett hőkamerát használtam fel, amelyet az EDP-TD modulhoz, pontosabban a kristály elülső felületétől megközelítőleg $30 \mathrm{~cm}$-re helyeztem el a pumpa- és magimpulzusok nyalábjai alatt. Emiatt a kamera kis szög alatt képezte le a kristályt és a körülötte lévő befogatás kis részét, azonban ez a hőmérséklet mérésében nem okozott problémát. A kamera chipje 160 x 120 pixeles felbontással tudott felvételt készíteni a 7,6 és $13 \mu \mathrm{m}$ közötti spektrális tartományon, 
120 fps sebességgel. Az érzékenységi tartomány a kamera gyári kalibrációja alapján a $-20{ }^{\circ} \mathrm{C}$ és $100{ }^{\circ} \mathrm{C}$ közötti hőmérséklet sávot fedte le. A hőkamera pozícionálását a IV.3.11. ábra mutatja. A hütés hatékonyságának teszteléséhez az erősítő elrendezés módosítása nélkül, két pumpalézer felhasználásával gerjesztve a kristályt mértem a hőmérséklet növekedését.

a.

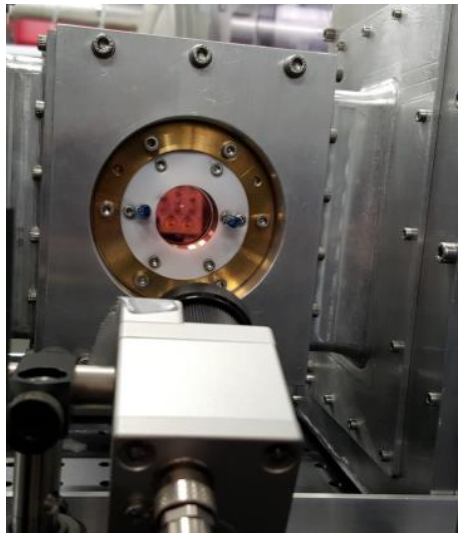

b.

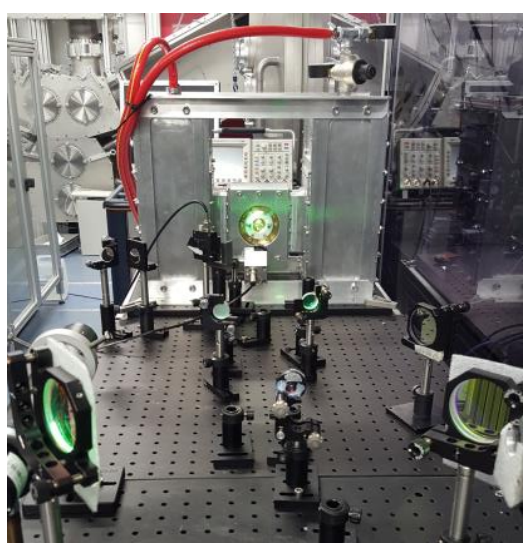

IV.3.11. ábra Hőkamera elhelyezése a TD modul előtt (a). TD modul a pumpálás közben (b). A fotó készítésekor a pumpaenergia a nyalábutak beállításához használt értékre lett korlátozva.

A mérés során magimpulzusok nem haladtak át az erősítőn, így energiakicsatolás nem történt erősítés formájában. Az erősítő közeget $4 \mathrm{~J}$ energiájú impulzusokkal pumpáltam $10 \mathrm{~Hz}$ ismétlési frekvencián a korábban használt geometriában, vagyis 2 passz (effektíve 4) volt felhasználva mindkét pumpanyaláb esetén. A mérés során .ravi fájl formátumban (radiometrikus videó formátum) rögzítettem a kristálybéli hőmérséklet-változást, amely később jól kiértékelhető adatokat biztosított. A hőmérséklet mérését a pumpálás kezdete előtt 4 másodperccel hamarabb indítottam el, majd a pumpálást követően 15 másodperccel később állítottam le. Az előbb leírt időzítési eljárás révén a kristály pumpálás előtti, hütés mellett kialakult hőmérsékleti egyensúlybéli állapotát vettem fel.
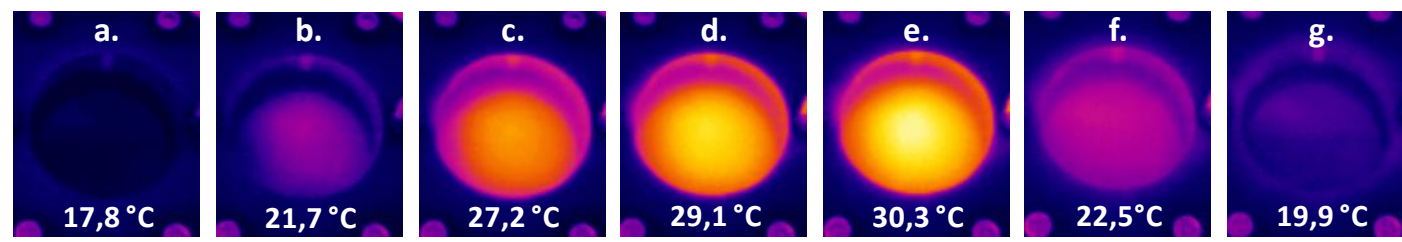

$30,3{ }^{\circ} \mathrm{C}$

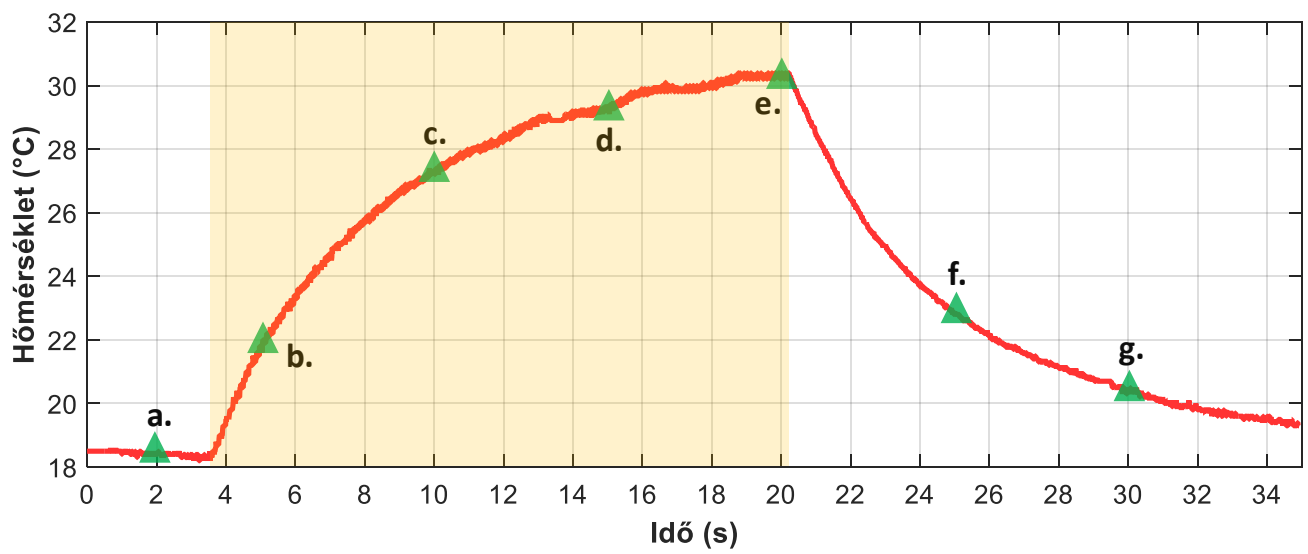

IV.3.12. ábra Maximális hőmérséklet időbeli fejlődése a Ti:Sa kristályban $10 \mathrm{~Hz}$ ismétlési frekvenciájú pumpálás esetén (piros görbe). A pumpálás időtartamát a narancssárga terület jelöli. A pillanatnyi hőmérsékleteloszlásokat az (a), (b), (c), (d), (e), (f) és (g) jelölésű képek prezentálják. Az egyes hőképek alján feltüntetett értékek a maximális hőmérsékletet jelölik az adott pillanatnyi eloszlásban. 
Az utóbbi pedig a felmelegedett kristály további, a hőterhelés megszünését követő lehűlési folyamatának rögzítését biztosította. A kristályban kialakult maximális hőmérséklet pumpálás hatására való megemelkedését, majd a pumpálás megszűnése utáni lecsökkenését a IV.3.12. ábra szemlélteti. A IV.3.12. ábráról leolvasható, hogy a pumpálás megkezdésétől közelítőleg 16 másodpercre volt szükség, hogy a kristály elérje a hőmérsékleti egyensúlyi állapotot. A csúcshőmérséklet értékére csak $30,3{ }^{\circ} \mathrm{C}-\mathrm{t}$ mértem, amely tekintettel a közel $40 \mathrm{~W}$ abszorbeált pumpateljesítményre, valamint a hütővíz alacsony, $0,35 \mathrm{~m} / \mathrm{s}$ áramlási sebességére igen alacsonynak mondható. Az első időpillanat $(2 \mathrm{~s})$ kivételével 5 másodpercenként ábrázolt hőmérséklet eloszlások (IV.3.12. ábra, (b), (c), (d), (e), (f) és (g) részek) egyértelmüen azt mutatják, hogy a hőmérsékletprofil mentes bármely jelentős hőmérsékleti gradienstől, valamint a pumpált térfogat szélein és centrumában kialakult hőmérséklet közötti különbség nem nagyobb mint $4{ }^{\circ} \mathrm{C}$ minden esetben. Az említett hőmérséklet-különbséget a hőmérsékleti egyensúlyban a IV.3.13. ábrán figyelhetjük meg. A hosszútávú működés vizsgálatára nem volt lehetőség, mert a Ti:Sa kristály elülső oldalán lévő antireflexiós réteg minőségi problémái miatt néhány száz pumpaimpulzust követően jelentős sérüléseket tapasztaltunk a rétegben. Ahogyan az a IV.3.13. ábrán észrevehetö, a kristály elülső felületén kialakult stacionárius hőmérséklet-eloszlás kissé aszimmetrikus.

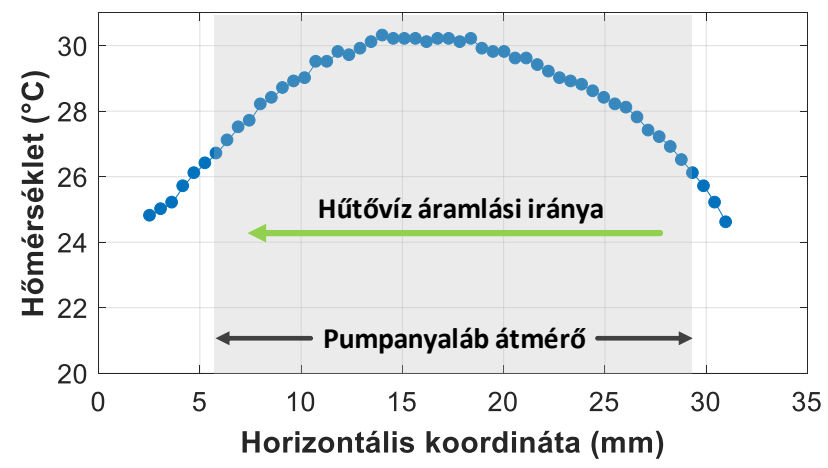

IV.3.13. ábra Hőmérséklet-eloszlás a kristály középső horizontális síkjában, a kristály elülső felületén.

Ennek oka, hogy a hütő folyadék és a kristály közötti hőátadási tényező a kristály azon szélétől, amellyel a folyadék elsőként érintkezik, lecsökken. Ezt a IV.3.13. ábrán a görbe jobb szélének alacsonyabb hőmérséklet értékei jelzik. Mivel a hủtővíz a kristályból hőt csatol ki, a víz hőmérséklete megnövekszik, és így annak dinamikai viszkozitása, valamint a két közeg közötti hőmérséklet-különbség lecsökken. Érdemes megemlíteni, hogy a kristályban a pumpálás eredményeként, az erősítés hiányában nagyobb mértékben fellépő TPG-t a kristály szélén elhelyezett abszorber elnyelni, azonban ennek pontos mértéke nem ismert. Az elnyelt TPG energia hőterhelést jelent a Ti:Sa kristály peremén, amely megemeli a szélek hőmérsékletét. Fontos azonban, hogy a jelen esetben kialakult hőmérséklet-gradiens igen kicsiny, így potenciálisan a kristályon történő többszöri áthaladás sem fogja jelentősen torzítani az erősítendő impulzusok hullámfrontjait.

\section{IV.3.6. Hullámfront torzulásának mérése}

Az erősített nyaláb alkalmazhatóságát egyértelmủen meghatározza, hogy annak hullámfrontja milyen mértékben torzult az erősítés folyamán. A végerősítőket követően gyakran alkalmaznak hullámfront korrekciót, amely deformálható tükrök felhasználásával valósítható meg [191]. A hullámfront torzulásához hozzájárul az aktív közeg felületi minőségének inhomogenitása a nyaláb által érintett felületen, a törésmutató megváltozása a kristály pumpált térfogatában a hőmérséklet megnövekedésének köszönhetően, a hőtágulás által a be- és kilépő felületek meghajlásai, valamint a 
hőmérséklet-változás hatására kialakuló mechanikai stressz által indukált kettőstörés a fotoelasztikus hatás révén [171].

Az EDP-TD erősítőben kialakuló hullámfront torzulást egy egyszerủ elrendezés segítségével mértem meg. Egy He-Ne lézer (Melles Griot) kitágított nyalábja segítségével kivilágítottam a Ti:Sa kristály teljes apertúráját, majd a hátsó felületről visszavert nyalábot egy teleszkópon keresztül egy SchackHartmann típusú (Imagine Optics, HASO) hullámfront szenzorba lőttem (IV.3.14. ábra).

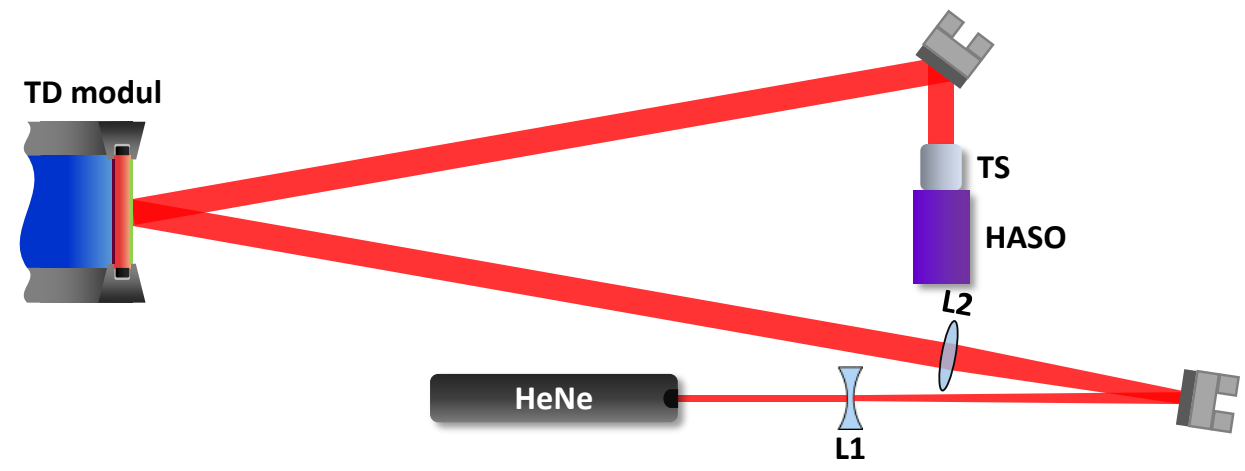

IV.3.14. ábra Hullámfront torzulásának mérésére felhasznált elrendezés. L1 és L2 lencséket, TE teleszkópot és HASO hullámfront szenzort jelöl. A nyaláb méretét az ábrán a jobb láthatóság érdekében lecsökkentettem.

A teleszkópra azért volt szükség, hogy a nyaláb méretét a HASO szenzor chip méretének közel felére csökkentsem. Mivel az erősítőben fellépő hullámfront-torzulást a pumpaimpulzusok abszorpciójának termikus hatásai határozzák meg, a hullámfront mérést a IV.3.5. fejezetben leírt hőmérsékletmérési kísérlettel szinkronizálva végeztem el. A $4 \mathrm{~J}$ energiájú impulzusokkal való pumpálás megkezdésétől rögzítettem a hullámfront torzulását. Mivel a pumpált kristálytérfogaton kívül az erősítendő impulzusok hullámfrontjának változásaihoz a kristály további részei nem járulnak hozzá, elegendő a pumpaimpulzusok által érintett apertúra részt vizsgálni. Az erősítés szempontjából a termikus egyensúlyi állapotban kialakult torzulás a legfontosabb, amit a IV.3.15. ábra szemléltet a pumpált kristály apertúrára vonatkozólag. A IV.3.15. ábra (a) részén a kristály pumpálandó apertúráján áthaladó He-Ne nyaláb hullámfrontját láthatjuk, amely a Ti:Sa kristály vágása és rétegezése során keletkezett inhomogenitásoknak köszönhetően már eleve rendelkezik 0,32 $\mu \mathrm{m}$ P-V (Peak-to-Valley, a maximum és minimum közötti különbség abszolút értéke) és $0,06 \mu \mathrm{m}$ RMS értékü hullámfront torzulással.
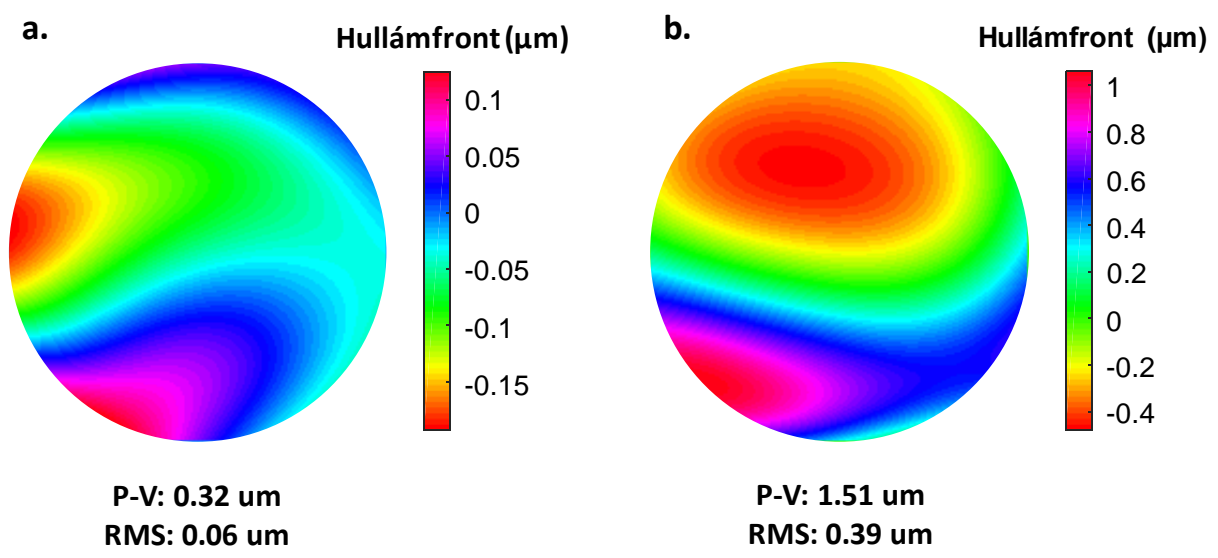

IV.3.15. ábra Hullámfront torzulása a pumpált apertúrában: hullámfront a pumpálás előtt (a) és a pumpálás közben a termikus egyensúly állapotában (b).

A IV.3.15. ábra (b) része már a pumpálás hatására kialakult hőmérsékleti egyensúly állapotában került rögzítésre (20 s időpillanatban a IV.3.12. ábrán). Megfigyelhető, hogy a P-V érték 1,51 $\mu$ m-re, addig az 
RMS érték pedig 0,39 $\mu$ m-re nőtt, ami egyértelmüen jelzi a termikus hatások jelenlétét. Felhívnám azonban a figyelmet arra, hogy ezen hullámfront paraméterek a kristály vastagságán kétszeri áthaladásra vonatkoznak.

\section{IV.3.7. Diszkusszió}

Az Yb-adalékolású erösítő közegek esetén kifejlesztett koronglézer geometria nagy áttörést jelentett az ultrarövid impulzusok elöállítására alkalmas fényforrások átlagteljesítményének növelésében. Ugyanezen geometria az ultranagy intenzitású impulzusok előállítására alkalmas Ti:Sa végerősítőkben való alkalmazása az elérhető ismétlési frekvencia jelentős megnövekedését eredményezheti. Az előzetes modellszámítások alapján az EDP-TD metódus nagymértékben csökkenti az erősítő kristályban kialakuló hőmérsékleti gradiens értékét a konvencionális erősítőkhöz képest.

Az EDP-TD végerősítő kísérleti demonstrációjához szükség volt egy 100 TW osztályú lézerrendszerre, amely mind a mag- mind pedig a pumpaimpulzusokat biztosítani tudta. Ehhez a MaxBorn-Institut 100 TW csúcsteljesítményü rendszerét használtam fel. Kutatótársaimmal kísérletileg demonstráltam egy EDP-TD Ti:Sa végerősítő müködését. A kísérlet során felhasznált $35 \mathrm{~mm}$ átmérőjü és $3 \mathrm{~mm}$ vastagságú Ti:Sa kristály a hátsó felületén közvetlenül érintkezett a $18{ }^{\circ} \mathrm{C}$-os hütővízzel, amely $0,35 \mathrm{~m} / \mathrm{s}$ áramlási sebességgel haladt át a hütőcsatornán. Az erősítőbe belépő $0,5 \mathrm{~J}$ energiájú magimpulzusokat 3 passz kialakításával erősítettem aktív tükör típusú elrendezésben. A pumpalézerek által biztosított $6 \mathrm{~J}$ pumpaenergiával $5 \mathrm{~J}$ abszorbeált energiát sikerült elérni a méréseink szerint, amely egyenletes eloszlása révén homogén populáció inverziót hozott létre a Ti:Sa kristályban. Az egylövéses erősítési kísérletek során 2,6 J erősített impulzusenergiát értem el a parazita effektusok elnyomásával.

A kristály hủtésének hatékonyságát $10 \mathrm{~Hz}$ ismétlési frekvencián $4 \mathrm{~J}$ energiájú impulzusokkal pumpálva vizsgáltam erősítés nélkül. Egy hőkamera segítségével rögzítettem a kristály felmelegedését, amely során a mérések szerint kevesebb, mint 20 másodperc alatt sikerült elérni a stacionárius állapotot. Az egyensúlyi állapotban mindössze $30,3{ }^{\circ} \mathrm{C}$ maximális hőmérsékletet mutattam ki, amely demonstrálja a EDP-TD módszer Ti:Sa kristállyal való használatának nagy potenciálját. A hőmérséklet mérésével párhuzamosan egy hullámfront szenzor segítségével mértem egy He-Ne lézer nyalábjának hullámfront torzulását is, amely egyszer verődött vissza a Ti:Sa kristály hátsó felületéről.

T3.a. TD geometria alkalmazását javasoltam az EDP módszerrel kombinálva nagyenergiájú Ti:Sa végerősítők átlagteljesítményének felskálázásához. Numerikus szimulációkkal összehasonlítottam egy konvencionális és egy EDP-TD technikával müködtetett 2 PW csúcsteljesítményü erősítő termikus hatásait. Az EDP-TD erősítő esetén jelentős javulást mutattam ki a hőmérséklet eloszlásában [TP3].

T3.b. Kísérletileg demonstráltam egy 100 TW osztályú EDP-TD Ti:Sa végerősítő fokozat müködését. Egylövéses kísérletekkel $5 \mathrm{~J}$ abszorbeált pumpaenergia és $0,5 \mathrm{~J}$ magimpulzus energia mellett 2,6 J erősített impulzusenergiát értem el [TP4]. A Ti:Sa kristályban kialakuló hőmérsékletet 4 J energiájú impulzusokkal $10 \mathrm{~Hz}$ ismétlési frekvencián vizsgálva egyenletes térbeli eloszlást tapasztaltam, és a hőmérséklet maximumára $30,3{ }^{\circ} \mathrm{C}$-ot kaptam. Megmértem a kristályban pumpálás esetén fellépő hullámfront torzulást a kristályon való kétszeri áthaladásra. 


\section{IV.4. EDP-TD végerősítők átlagteljesítményének felskálázása}

A IV.3. alfejezetben ismertetett szimulációs és kísérleti eredmények alapján elmondható, hogy az EDP-TD technika alkalmazása magasabb ismétlési frekvenciák, azaz nagyobb átlagteljesítményü impulzusok erősítését is lehetővé teszi a nagyenergiás erősítők esetén. Ahhoz, hogy a felskálázás termikus határait megállapítsuk, további modellszámítások elvégzése szükséges a lehetséges geometriák és lézerparaméterek mentén. Az erősítő közegben különböző lézerparaméterek mellett kialakuló hőmérséklet-eloszlás pontosabb meghatározásához szükséges a hütés részletesebb elemzése. Ehhez a hőterjedés mellett a folyadékáramlást is ki kellett számítanom, amit a COMSOL Multiphysics szoftver segítségével végeztem el. A következő alfejezetekben a HF-100 lézerrendszer Ti:Sa EDP-TD végerősítőjének lehetséges paramétereire végzett numerikus szimulációk eredményeit fogom közölni. Továbbá, a numerikus modellt felhasználva megvizsgálom az EDP-TD módszer nagyobb energiájú erősítőkre való alkalmazását különböző ismétlési frekvenciák esetén.

\section{IV.4.1. Vizsgált geometriák és lézerparaméterek}

Szimulációim során két hütési koncepciót vizsgáltam meg: egycsatornás hütést reflexiós optikai sémával (IV.4.1.1. ábra, (a) rész), valamint kétcsatornás hütést transzmissziós optikai sémával (IV.4.1. ábra, (b) rész). Az egycsatornás hütés esetén a kristály hátsó optikai felülete HR bevonattal, míg elülső felülete pedig AR bevonattal van ellátva a pumpa- és a magimpulzusok hullámhossztartományán, hasonlóan a IV.3. alfejezetben leírtakhoz.
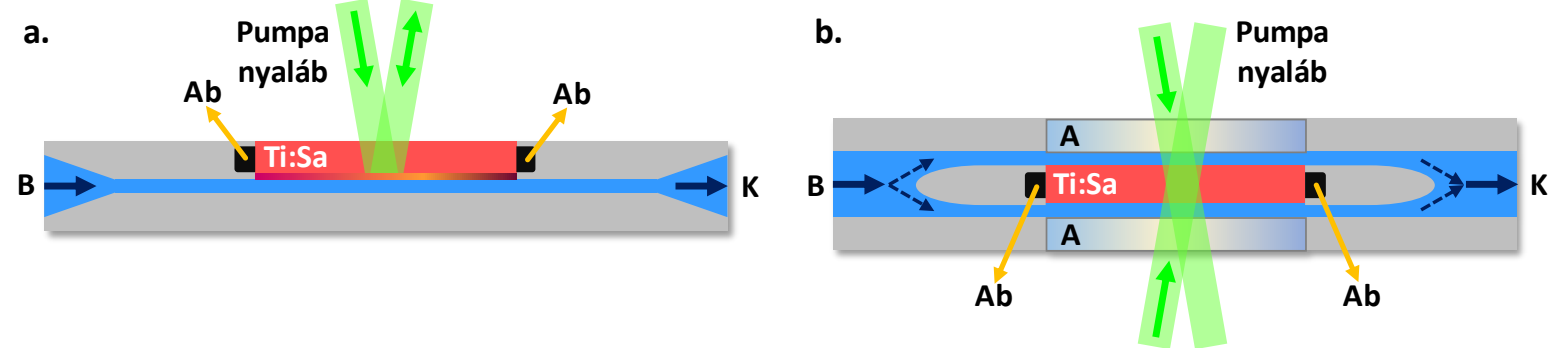

IV.4.1. ábra Sematikus hủtőmodul elrendezés felülnézeti képe egycsatornás (a) és kétcsatornás (b) esetekre, ahol B bemenetet, K kimenetet, A ablakokat, Ab pedig abszorbert jelöl.

A Ti:Sa kristály ebben az elrendezésben aktív tükörként funkcionál, amely révén egy reflexió két átmenetet jelent az erősítő közegen keresztül. Ebben az esetben a nyalábok nem haladnak át a hütőközegen, és így a nyalábok hullámfrontja nem szenved el torzulást a hütőfolyadékon való áthaladás miatt. A kétcsatornás hütés esetén a Ti:Sa kristály mindkét optikai felülete AR bevonattal rendelkezik a pumpa- és magimpulzusok hullámhosszaira vonatkozóan. A transzmissziós optikai séma maga után vonja, hogy mind a pumpa-, mind pedig a magimpulzusok áthaladnak a két folyadékcsatornán, amelynek torzító hatásai lehetnek a nyalábok hullámfrontjaira. Ennek fényében, a kétcsatornás hütést úgy kell megtervezni, hogy a folyadékáramlás mindkét csatornában kellően zavarmentes legyen.

Szimulációim során egy 100 TW csúcsteljesítményü impulzusok $100 \mathrm{~Hz}$ ismétlési frekvencián való elöállításához szükséges végerősítő fokozat paramétereit vettem alapul. Konzervatív módon 50\%-os energiakicsatolási hatásfokot feltételezve, az erősítő kristályt $6 \mathrm{~J}$ energiával pumpálva közel $3 \mathrm{~J}$ energiájú erősített impulzusok állíthatóak elő. Ehhez minden esetben a pumpaimpulzusok energiájának 95\%-os abszorpcióját tételeztem fel, amely a valóságban is kivitelezhető. Ekkor az abszorbeált pumpaenergia 50\%-a hő formájában tárolódik az erősítő kristályban. Könnyen kiszámolható, hogy ebben az esetben mind a kicsatolt magimpulzusok, mind pedig a fütési átlagteljesítmény $300 \mathrm{~W}$ körüli 
értéket vesz fel. A jó hatásfokú erősítés eléréséhez a pumpaimpulzusok $2 \mathrm{~J} / \mathrm{cm}^{2}$ energiasürüségének elérése szükséges a kristály pumpált térfogatában mindkét optikai séma esetén. Ehhez 19,5 mm átméröjü pumpanyalábra van szükség mindkét esetben. A kívánt erősítés eléréséhez a reflektív séma esetén 3 passz elegendő (effektíve 6 passz) a magimpulzusok esetére, míg a transzmissziós séma esetén ez 4 átmenettel is megoldható, mivel ekkor a kristály vastagsága nagyobb lehet. A szimulált erősító kristály egycsatornás hütés esetén egy $35 \mathrm{~mm}$ átmérőjü és $3 \mathrm{~mm}$ vastagságú, addig a kétcsatornás hủtés esetén az előzővel megegyező átméröjü, de 4 és $6 \mathrm{~mm}$ vastagságú korong volt. Kísérleti tapasztalataim alapján az egycsatornás esetben alkalmazott $3 \mathrm{~mm}$ vastagság az a minimális érték, amely a folyékony abszorber alkalmazása mellett még technikailag elfogadható, így ebben az esetben további vastagságbéli csökkentésre jelen ismereteim szerint nincs lehetőség. A két csatornás esetben a $6 \mathrm{~mm}$ vastagság az egycsatornás eset transzmissziós sémával kapható megfeleltetése (kétszeres vastagság). Ez azonban optimalizáció érdekében csökkenthető, és figyelembe véve az erősítési paramétereket, valamint az abszorber korongvastagságra vonatkozó igényét, $4 \mathrm{~mm}$ vastag kristály vizsgálata mellett döntöttem. Mindkét hütés esetén a Ti:Sa kristály abszorpciós együtthatóját 2,51/cm értékre állítottam. A pumpaimpulzusok kristályon való áthaladásainak számát a 95\%-os abszorpció eléréséhez szükséges 2 passzra (effektíve 4 passz) állítottam be az egycsatornás hütés esetén. A kétcsatornás hütést tekintve a $6 \mathrm{~mm}$ vastag kristály esetén 2 passz, addig a $4 \mathrm{~mm}$ vastag kristály esetén 3 passz volt szükséges kétoldali pumpálás mellett a kívánt abszorpció eléréséhez. Mindemellett, az abszorbeált pumpaenergia eloszlása a longitudinális irányban kellően homogén lesz, amely optimális az erősítéshez. A hütőközeg hőmérsékletére $15^{\circ} \mathrm{C}$ értéket adtam meg, amely a jelenleg elérhető hütőberendezések esetén jól alkalmazható, és standard laborkörülmények között még nem okoz az optikákon páralecsapódást.

\section{IV.4.2. Kétdimenziós modell: hőmérsékleti peremfeltétel}

Kiindulópontként egy egyszerü modellt alkottam, amelyben csak a hővezetési problémát oldottam meg a kristályban. A későbbi folyadékhűtéses szimulációk számításigénye miatt a kétdimenziós modellezés mellett döntöttem, amellyel már kellő pontosságú eredmények nyerhetőek a későbbi felskálázás során is. Tekintve, hogy számunkra kielégítő a hőmérsékleti egyensúlyban beállt hőmérséklet-eloszlás ismerete, a stacionárius hőterjedési egyenletet oldottam meg a Ti:Sa kristályban.

a. $T=T_{h}$

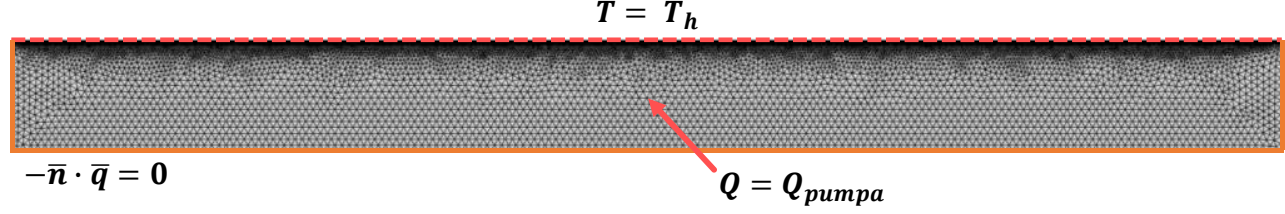

b.

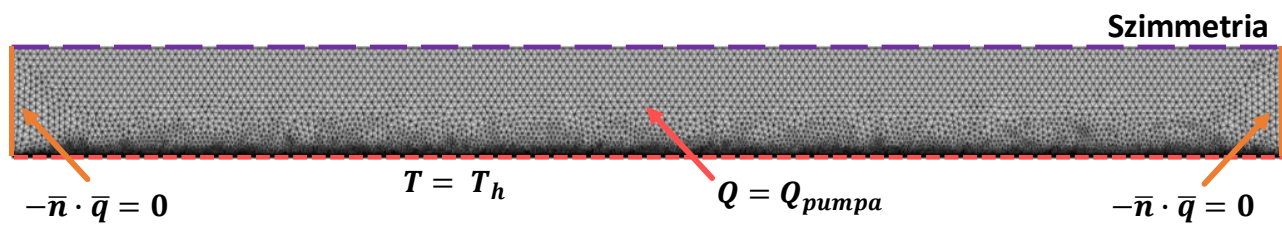

IV.4.2. ábra Peremfeltételek és a geometria hálóstruktúrája az egycsatornás (a) és kétcsatornás (b) hütésű kristály esetére. A hálózás a hőmérsékleti perem felé sűrüsödik. Pirossal a hőmérsékleti, naranccsal a hőszigetelési és lilával a szimmetria peremfeltételt jelöltem. Hőforrásként a $Q_{\text {pumpa }}$ szolgál, amely a disszipált pumpateljesítmény.

A hőterjedési probléma matematikai leírását a Függelék XI.1. része tartalmazza. A peremfeltételek megadását ebben az egyszerủ modellben a IV.4.2. ábra szemlélteti. A hütöttnek feltételezett peremen 
hőmérsékleti peremfeltételt vettem fel, amely által azt állandó hőmérsékleten tartottam. Így ezen a peremen a hőátadási tényező végtelen nagy, amely az ideális hütést szimulálja. Tekintettel arra, hogy a kétcsatornás esetben a kristály közepén longitudinális irányban végigfutó tengely szimmetriatengely, ott szimmetria peremfeltételt alkalmazva felére csökkentettem a szükséges szimulált geometriát, s így a hálóelemek számát is (IV.4.2. ábra, (b) rész). A pumpaimpulzusok hőterhelését az erősítő kristályban az egycsatornás hütés esetén a Függelék XI.1. alfejezetében leírt (XI.8), míg a kétcsatornás hütés esetén az (XI.9) egyenletek felhasználásával adtam meg. A 6 mm vastag kristály esetén két első és hátoldali átmenetet állítottam be, addig a $4 \mathrm{~mm}$ vastag korong esetén már három átmenetre volt szükség mindként oldalról. Ez azt jelenti, hogy az egyik oldalról áthaladó passzt visszareflektáljuk a kristályra, és azon újra áthalad, ezen esetben a másik felület felől. A Ti:Sa kristály hőmérséklettől függő fizikai tulajdonságait a COMSOL Material Library szoftverrészlet felhasználásával adtam meg.

Lefuttatva a modellt a két különböző hütési- és optikai séma esetére megkaptam a termikus egyensúly esetén kialakult hömérsékletprofilt a kristályban. Az egycsatornás hütés esetén $64,8{ }^{\circ} \mathrm{C}$ maximális hőmérséklet adódott szimmetrikus profillal (IV.4.3. ábra, (a) rész). A profil szimmetriája a hütött peremen felvett konstans $15^{\circ} \mathrm{C}$ hőmérsékleti peremfeltétel eredménye. Kétcsatornás hủtést szimulálva a $6 \mathrm{~mm}$ vastagságú kristály esetén $36,9^{\circ} \mathrm{C}$-ra csökkent a maximális hömérséklet értéke (IV.4.3. ábra, (b) rész), míg a vastagságot 4 mm-re csökkentve már csak $29,9^{\circ} \mathrm{C}$ adódik a csúcshőmérsékletre (IV.4.3. ábra, (c) rész). A kétcsatornás hütés esetén megduplázódott a hütött kristályfelület, amely jól látható javulást eredményezett a csúcshömérséklet értékében. A legfontosabb, hogy a kristály pumpált térfogatában a centrum és a szélek között csökkent a hőmérsékleti gradiens értéke. Ez a gradiens meghatározza az erősítendő impulzusok hullámfrontjára vonatkozó torzító hatást a kristály törésmutatójának megváltozása, a hőtágulás, illetve az anyagban keltett mechanikai feszültség által. A kristály vastagságának 4 mm-re csökkentésével további csúcshömérséklet-csökkenést értünk el, valamint a hőmérsékleti gradienst is alacsonyabb szintre szorítottuk.

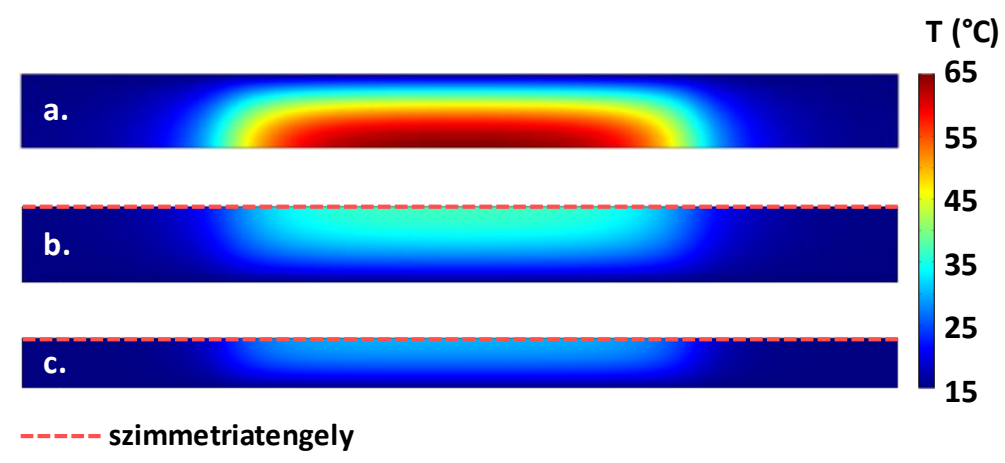

IV.4.3. ábra Hőmérséklet kétdimenziós eloszlása a $15^{\circ} \mathrm{C}$-on hütött kristályban egycsatornás hütéssel és 3 mm korongvastagsággal (a), kétcsatornás hütéssel és $6 \mathrm{~mm}$ (b) illetve $4 \mathrm{~mm}$ korongvastagság (c) mellett. A (b) és (c) ábrák esetén a kristály felét ábrázoltam.

Már ebből az egyszerü modellből is jól látható, hogy a TD módszer segítségével a kristály pumpált térfogatában jó homogenitású hőmérsékletprofilt alakíthatunk ki, amely révén nagy ismétlési frekvenciák, vagyis nagy átlagteljesítményü impulzusok esetén is fenntartható az erősítést követően a nyalábprofil minősége. Belátható azonban, hogy a fentiekben leírt egyszerü modell a valóság idealizálása, amely nem szolgál elegendő információval egy lézerfej termikus határainak pontos meghatározásához. Emiatt a modellt kiegészítettem a hütés hatásfokát alapvetően meghatározó, hűtőcsatornákban kialakuló folyadékáramlási probléma megoldásával. 


\section{IV.4.3. Kétdimenziós részletes modell}

A Ti:Sa kristály folyadékhűtésének modellezéséhez szükség van a kristályban, illetve a kristállyal érintkező hütőfolyadékban kialakuló hővezetés, valamint a folyadék áramlásának meghatározására. Mindemellett, az egyes fizikai folyamatok hatnak egymásra, vagyis a kristályból kicsatolt hő az azt átvevő folyadékréteget felmelegíti, amelynek így megváltozik a sürüsége és viszkozitása, tehát az áramlási paraméterek is módosulnak. Ebből következően a folyadékáramlást és a hővezetést leíró differenciálegyenletek csatoltak. A COMSOL szoftverben a folyadékáramlást a Computational Fluid Dynamics (CFD) modul segítségével végeztem el. Tekintettel arra, hogy nagy hütési teljesítményre van szükség, előzetesen kijelenthetö, hogy a kristály hütött felületénél IV.3. fejezetben használt $0,35 \mathrm{~m} / \mathrm{s}-$ nál nagyobb, több m/s értékü folyadékáramlási sebességre van szükség. A nagy áramlási sebesség miatt már átmeneti áramlásról van szó a csatornában, emiatt a turbulens áramlást leíró modellek egyikét kellett alkalmaznom. Egy ún. nyirás réteg szállitás (shear stress transport, SST) modellt [193-195] használtam fel, amely egy alacsony Reynolds-számú modell. Erre azért van szükség, mert a kristály és a hütőfolyadék határfelületén végbemenő hőtranszport felbontása nagy pontosságot igényel. Az SST modell alapegyenleteinek tárgyalása a Függelék XI.2. részében található. Ez a modell bár jelentős számítási kapacitást használ fel, nem alkalmaz fal-függvényeket az áramlási csatorna falához közeli régiókban, ezáltal az áramlási sebesség határrétegét (boundary layer) nem közelítéssel adja meg, hanem az áramlást leíró egyenletekböl közvetlenül határozza meg. Normál esetben az áramlási paraméterek meghatározására az ún. $k$ - $\omega$ vagy $k$ - $\varepsilon$ [196] típusú turbulens modelleket szokás alkalmazni, amelyek jóval kisebb számítási igénnyel rendelkeznek, azonban a jelen problémánál jóval nagyobb Reynoldsszámú $\left(>10^{5}\right)$ áramlások leírására optimálisak és a falakhoz közeli régiókban közelítéseket használnak.

A szükséges áramlási sebesség kialakításához a kristály és a folyadék érintkezési régiójában a két hütési módszer esetére különböző csatorna elrendezések kerültek megtervezésre az ELI-ALPS mérnökei által. Tekintettel arra, hogy a csatornarendszer méretei $60 \mathrm{~cm}$ x $6,5 \mathrm{~cm}$ x $6 \mathrm{~cm}$ körüliek, annak középső metszetét kétdimenziós esetben modelleztem le a számítási igények lecsökkentése, valamint a háromdimenziós konvergencia-problémák elkerülése miatt. A két különböző csatorna elrendezés CAD modelljeit a COMSOL szoftverbe importáltam, ezeket a IV.4.4. ábra szemlélteti.

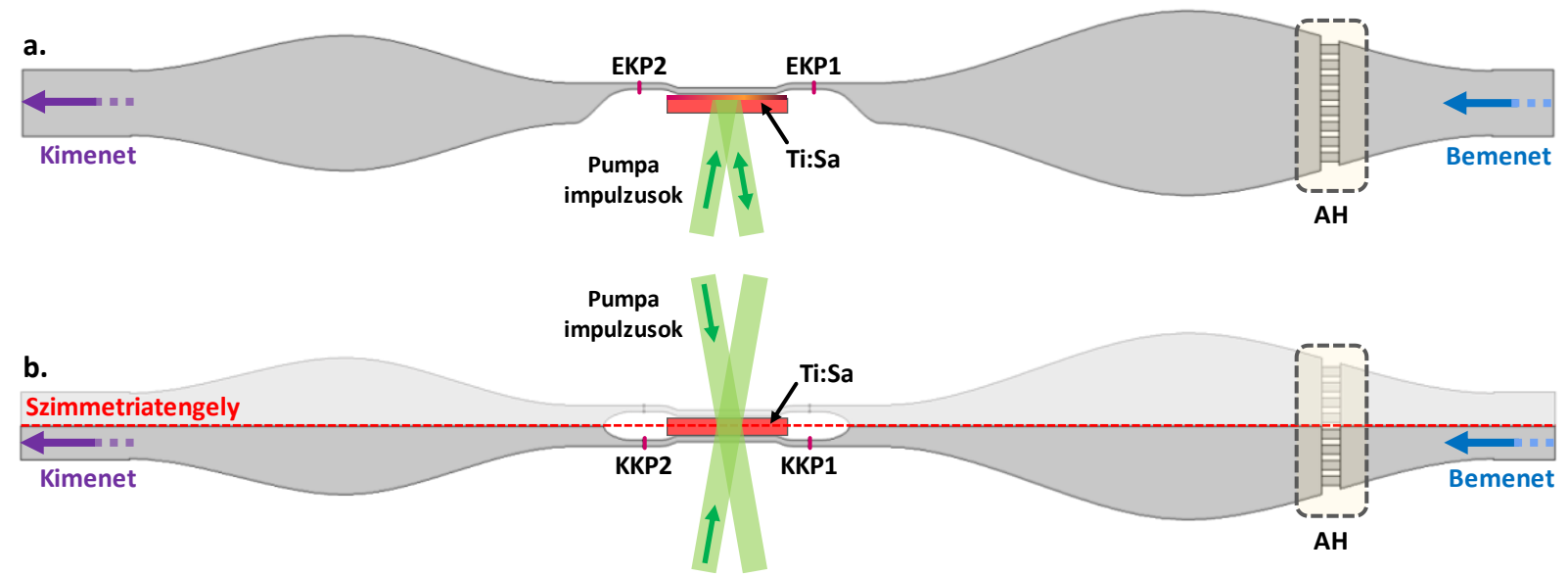

IV.4.4. ábra Egycsatornás (a) és kétcsatornás (b) hűtés kétdimenziós modelljei a pumpanyaláb útvonalának feltüntetésével. AH áramlás homogenizáló elemet, EKP1 és EKP2 egycsatornás központi peremet, KKP1 és KKP2 kétcsatornás központi peremet jelölnek.

Mivel az SST modell megoldása ilyen méretü geometriára még kétdimenziós esetben is magas számítási igényü (amennyiben a kellő sűrüségü hálózás legenerálható, > 24 óra), valamint konvergencia- 
problémák léphetnek fel, a modell futtatását két részre osztottam. Elsőként a IV.4.4. ábrán látható csatornákban az egyszerúbb $k-\omega$ modell [196] segítségével meghatároztam a stacionárius áramlási paramétereket, amely a mérsékelt időigény miatt volt előnyös. A megoldás jóságát a COMSOL szoftverben található, az eredmények között kapott ún. Wall lift-off érték segítségével ellenőriztem, amely a falakhoz közeli régiókban a hálózás sürüségéhez kapcsolódó mennyiség. Ezt követően leszükítettem a modellezett geometriát oly módon, hogy a IV.4.4. ábrán egycsatornás esetben EKP1 és EKP2-vel, míg a kétcsatornás esetben KKP1 és KKP2-vel jelölt peremekig vettem fel a csatornát a kontaktzóna belsejétől kifelé haladva, illetve a kristályt hozzáadva megkaptam a részletes modell alapjául szolgáló geometriát. A kétcsatornás esetben mind az egyszerübb $k$ - $\omega$ modell futtatásakor, mind a részletes modell esetén a teljes geometria felét vettem csak fel, mivel a hosszanti tengely szimmetriatengelyként használható. A $k-\omega$ modellhez használt teljes csatornát tartalmazó modellben az említett peremek (EKP és KKP) virtuálisak, arra használhatóak, hogy a kapott áramlási paramétereket ezen peremeken kezdeti feltételként csatolhassuk a részletesebb áramlás-hőtani modellhez. Ennek megfelelően a részletes modell jóval kisebb méretủ geometriájában az EKP és KKP peremek az áramlás be- és kimeneti peremfeltételeit vették fel, ahol is bemeneti peremfeltételként a $k$ - $\omega$ modell lefuttatásának eredményeként kapott sebességprofilt, nyomást, turbulens kinetikus energiát és a fajlagos disszipációs sebességet adtam meg [196].

A $k$ - $\omega$ modellből származó áramlási paraméterek alapján megadott kezdeti feltételekkel és a csatorna bemenetén felvett peremfeltétellel elértem, hogy a központi rész geometriáján értelmezett SST modell mindig konvergáljon, valamint a valósághoz közelebb álló feltételeket kaptam az áramlásnak a csatorna korábbi részében való fejlődésének figyelembe vétele miatt. Az áramlást leíró egyenleteket stacionárius esetre oldottam meg. A hütőfolyadék kompresszibilitását elhanyagoltam, mivel kis méretű csatornáról beszélünk, és relatíve kis távolságú áramlásról, amely révén jelentős sürüségváltozásról nincs szó a rendszerünkben. A laboratóriumi megvalósítás, valamint a kedvező fizikai tulajdonságai miatt hütőfolyadékként vizet tételeztem fel, amelynek a bemeneten felvett hőmérsékletét a korábbiaknak megfelelően $15^{\circ} \mathrm{C}$-ra állítottam. A csatorna kimenetén mind a $k$ - $\omega$, mind az SST modell esetén konstans zéró nyomású peremfeltételt szabtam. A csatorna falait hőszigeteltnek tételeztem fel. A víz hőmérsékletfüggő fizikai tulajdonságait a COMSOL Material Library [184] adatainak felhasználásával adtam meg. Hőforrásként a (IV.4.1.) és (IV.4.2.) formulák alapján megadott abszorbeált pumpaenergiát definiáltam.

\section{IV.4.4. Eredmények egycsatornás hütés esetére}

Az egycsatornás hütés esetén a csatorna bemenetén szükséges kezdeti áramlási sebességet a bemeneti peremre merőleges profillal állítva a kristállyal való érintkezési zónában $2,2 \mathrm{~m} / \mathrm{s}$ és $6,3 \mathrm{~m} / \mathrm{s} \mathrm{közötti}$ áramlási sebességet hoztam létre. Tekintettel arra, hogy ha a csatorna bemenetére vízcsövet csatolunk, a csatolóelemen való áthaladás a folyadékban jellemzően zavarokat okoz. Emiatt a diffúzor elött egy homogenizáló szükítő elem került elhelyezésre. Ezt követően a konfúzorban a csatorna szükülésével relatíve egyenletes növekedés jön létre az áramlási sebességben, majd az a kontakt zónában felveszi csúcsértékét. Végül a csatorna kitágulásával az áramlás sebessége lecsökken, majd a folyadék elhagyja a hütőfejet a kimeneti csatlakozáson keresztül (IV.4.4. és IV.4.5. ábrák). A $k$ - $\omega$ modellből adódó, IV.4.5. ábrán megfigyelhető áramlási sebességeloszlások bár jól mutatják, hogy a kontakt zónában sikerült homogén sebességprofilt kialakítani, a hőkicsatolás folyamatát ezen modell használatával erősen alábecsülnénk. Ennek oka, hogy a sebesség gradiense a falak mentén a fal-függvények használata miatt jóval kisebb a valóságban fellépő értékeknél. 


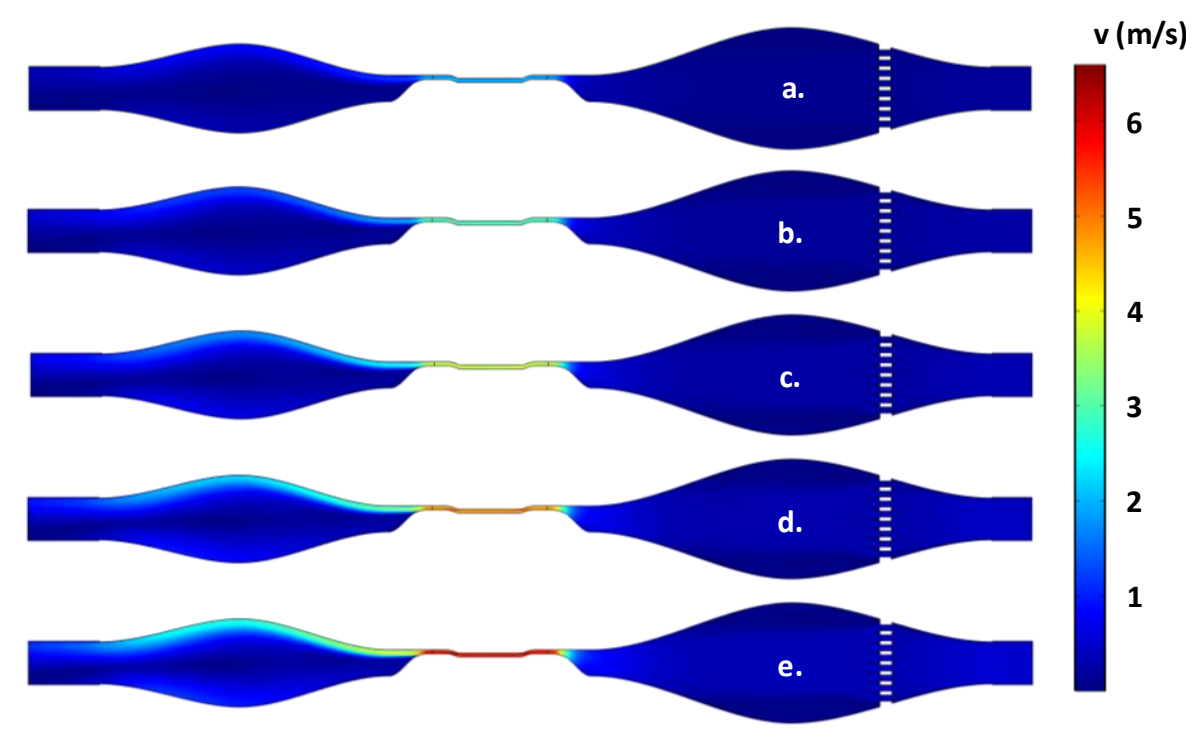

IV.4.5. ábra A $k$ - $\omega$ modellből áramlási sebesség abszolút értékének eloszlása az egycsatornás hütés esetén különböző bemeneti sebességekre: $0,17 \mathrm{~m} / \mathrm{s}$ (a), $0,25 \mathrm{~m} / \mathrm{s}$ (b), $0,33 \mathrm{~m} / \mathrm{s}$ (c), 0,42 m/s (d) és $0,5 \mathrm{~m} / \mathrm{s}$ (e).

Az SST modellt a hővezetéssel csatolva, illetve a geometria központi részét a fizikai problémának megfelelően jóval sürübben behálózva a részletes modell megoldható. Mivel az SST modell nem használ fal-függvényeket, a háló a falakon és azokhoz közeli régiókban jelentősen sürübb kell, hogy legyen, mint a $k$ - $\omega$ modell esetén (IV.4.6. ábra).

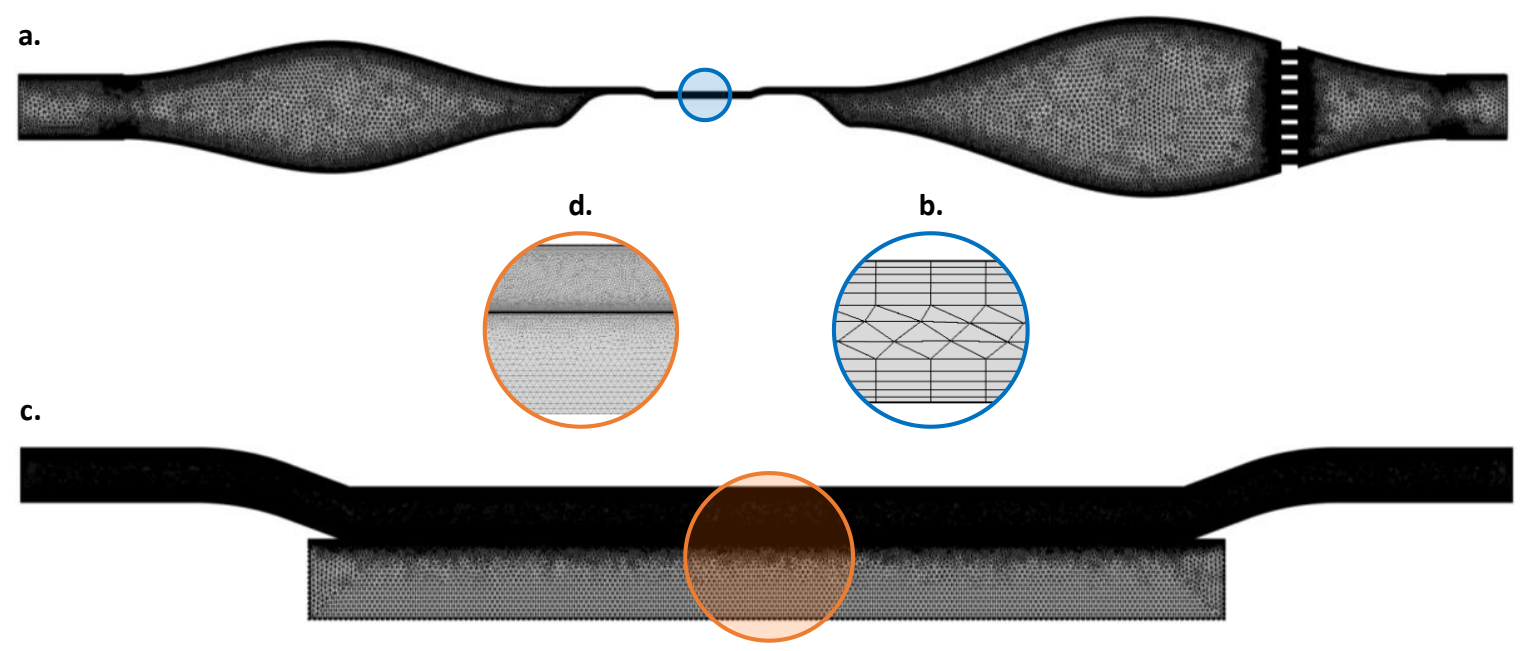

IV.4.6. ábra Hálózás összehasonlítása a két részmodell esetén. A háló a teljes csatorna esetén 48000 elem számosságú (a), amely a kékkel jelzett nagyításban jól láthatóan ritkának minősíthető (b). A központi rész modellje esetén a háló annak ellenére, hogy a teljes geometria területének csupán 62-ed részét fedi le, számossága így is 164000-re tehető (c). Belenagyítva a (c) részbe, a csatorna és a kristály hálózásának megnövekedett sürüsége jól kivehető (d).

Továbbá, mind az áramlási paraméterek kiszámításához, mind a hőkicsatolás korrekt feloldásához szükséges a csatorna falai, valamint a kristály és a folyadék érintkezési peremén az ún. határréteg hálózás (boundary layer mesh) alkalmazása. A határfelületeknél való jó adaptációs lehetőségei miatt minden modellben háromszög alapú hálózást alkalmaztam. A szimuláció lefuttatását követően az SST modell esetén is ellenőriztem a beépített jósági tényezőt, amely az ún. cella középpontjától mért távolság, amely egy dimenziómentes mennyiség, és a fal menti hálósűrúséget jellemzi. Amennyiben ez a mennyiség 0,5 érték alatti a geometria minden részén a csatorna be és kimeneti részeitől eltekintve, a megoldás elfogadható [184]. A hővezetési probléma megoldása kevésbé érzékeny a háló sűrűségére. A 
kristály és a folyadék érintkezési peremén a háló eleve rendkívül sűrü az áramlás felbontása miatt, a kristály belsejében pedig a háló adaptálódik ehhez a sürüséghez a perem közelében.

Az áramlási sebesség SST modell megoldásából származó eloszlásait a IV.4.7. ábra (a-e) részein figyelhetjük meg. A kontaktzónában jól kifejlődött áramlási profilokat kaptam, amelyek optimálisak a kristályban felhalmozódó hő kicsatolására. Ábrázolva a hőmérséklet stacionárius eloszlását a IV.4.7. ábra (f-j) részein láthatóakat kaptam. A IV.4.7. ábra (f) részén megfigyelhető eloszlás az (a) részben vizualizált sebességeloszlás esetén adódott, és így tovább a többi részábra esetén. A hőmérséklet profilja a Ti:Sa kristályban kismértékben aszimmetrikus, amely annak köszönhető, hogy a höátadási tényező a kristály és a víz között a folyás irányában lecsökken. Ez a folyamat a kristály felületénél jelen modell esetén $50 \mu \mathrm{m}$ körüli vastagságú hőmérsékleti határréteg [197] fejlődésével kapcsolatos. A folyadék áramlásának irányában haladva ugyanis a határrétegen belül csökken a hőmérsékleti gradiens a kristály és a folyadék részecskéi között, amely révén csökken a hőátadás is. Az effektus eredményeként a kristály azon fele, amely a folyadékkal elsőként érintkezik, alacsonyabb, addig a túlsó oldala magasabb hőmérsékletü lesz, valamint a hőmérséklet profilja a kristályon belül aszimmetriát mutat.

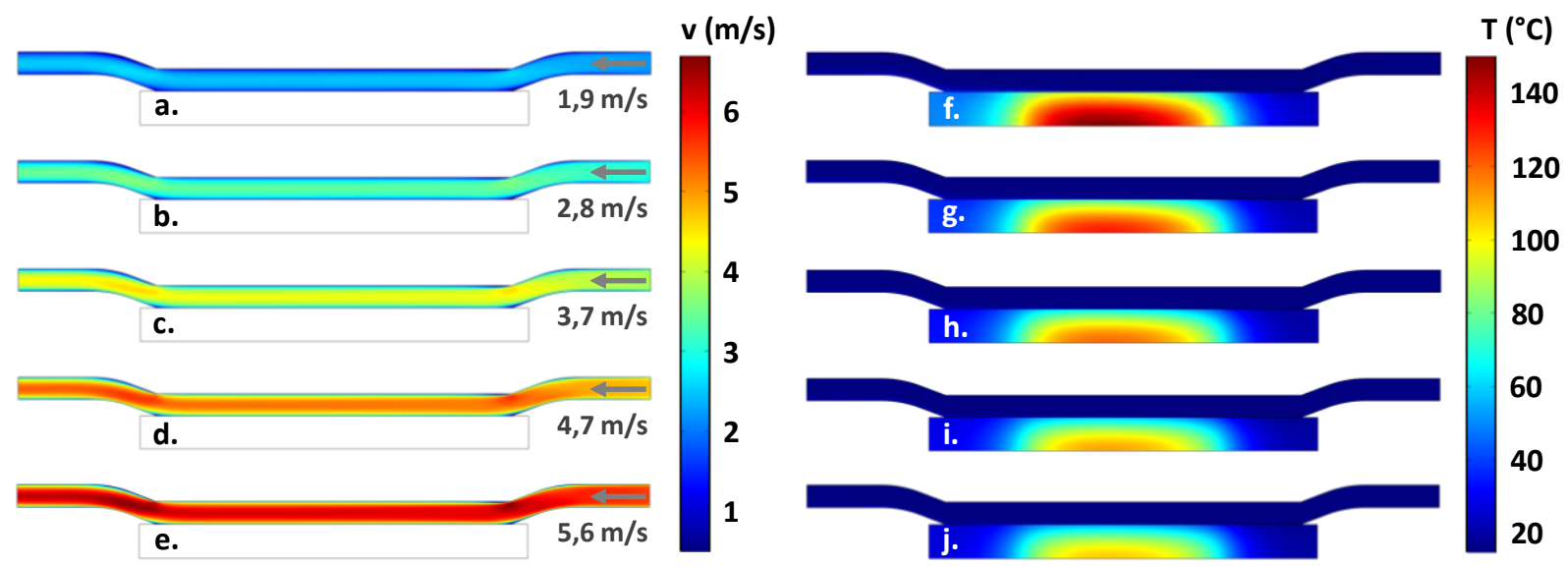

IV.4.7. ábra SST modellből kapott áramlási sebesség abszolút értékének eloszlása különböző bemeneti sebességek esetén (a-e), illetve az SST modellhez csatolt hővezetési egyenletek megoldásaként adódott hőmérséklet-eloszlások a velük egy magasságban vizualizált áramlási sebességeknek megfelelően (f-j).

A hütővíz kezdeti hőmérsékletéhez képest kialakult maximális hőmérséklet-növekedés értékét a kristály belsejében különböző áramlási sebességek esetén a IV.4.8. ábra mutatja be.

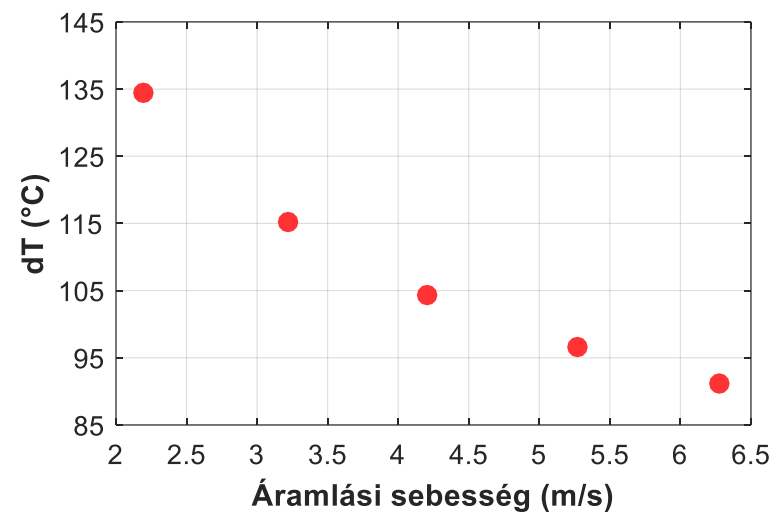

IV.4.8. ábra Hőmérséklet maximális növekedése különböző áramlási sebességekre az egyoldali hűtés esetén.

A IV.4.8. ábráról leolvasható, hogy a kristállyal érintkező csatornarészben kialakuló áramlási sebesség $2,2 \mathrm{~m} / \mathrm{s}$-ról $6,3 \mathrm{~m} / \mathrm{s}$-ra történő megnövelésével a maximális hömérséklet-változás $134,5^{\circ} \mathrm{C}$-ról $91,2{ }^{\circ} \mathrm{C}$ ra mérsékelhető. Az alacsonyabb maximális hőmérséklet miatt csökken a gradiens értéke a pumpált 
terület szélei és centruma között. Továbbá, jól látható, hogy a IV.4.7. ábra (f) részén látható hőmérsékletprofil egyre szimmetrikusabbá válik a (j) részig haladva. Ez az erősítendő nyalábra nézve egyre kisebb hullámfront torzulást jelent az erősítés folyamán. Összehasonlítva a IV.4.2. alfejezetben ismertetett, hőmérsékleti peremfeltétellel kapott eredményt az egycsatornás hütésre a folyadékhütéses modellel, a két modell közötti mintegy $26^{\circ} \mathrm{C}$ eltérés az előbbi modell ideális esetétől való eltérés mértékét mutatja.

A kiszámított hőmérséklet-változás hatását a hullámfrontra az erősítendő impulzus kristályon való áthaladása során érzékelhető optikai úthosszkülönbség meghatározásával vizsgáltam meg. Ehhez a Ti:Sa törésmutatójának hőmérsékletfüggését használtam fel. Számításaim során nem vettem figyelembe a hőtágulásból, illetve a mechanikai feszültségek által indukált kettőstörésből származó járulékokat [171]. Mivel a hőmérséklet profiljának homogenitása miatt ezek jóval kisebbek, mint a törésmutató hőmérsékletfüggéséből származó járulék, az eredmények jó közelítésnek tekinthetőek. A kristály törésmutatójának változását 799 nm hullámhosszon számoltam ki, és az egyik optikai perem felől haladva a másik peremig a transzverzális irányban integráltam azt a

$$
\Delta d(x, y)=\int \frac{d n}{d T}\left[T(x, y)-T_{v i z}\right] d y
$$

kifejezés szerint, ahol $\Delta d$ az optikai úthosszkülönbség, $d n / d T$ a Ti:Sa törésmutatójának elsőrendü hőmérsékletfüggése, valamint $T_{v i ́ z}$ a hütőfolyadék kezdeti hőmérséklete. A kristály $d n / d T$ együtthatójának értékének $799 \mathrm{~nm}$ hullámhosszon $1,229 \cdot 10^{-5} 1 /{ }^{\circ} \mathrm{C}$-ot vettem [69].

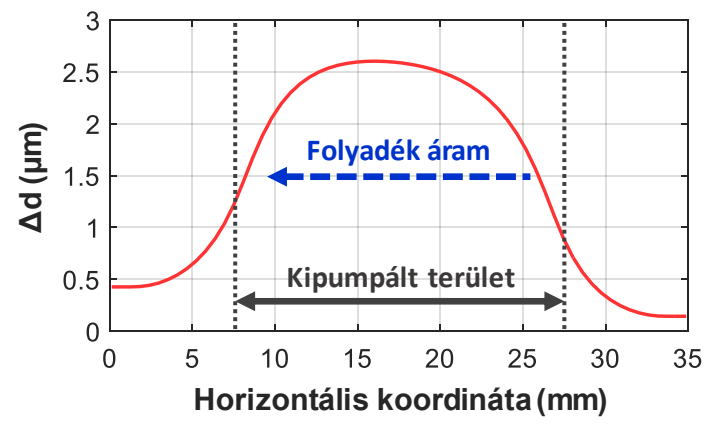

IV.4.9. ábra Optikai úthosszkülönbség a radiális irány mentén a kristályon történő egyszeri áthaladásra. Az áramlási sebesség $6,3 \mathrm{~m} / \mathrm{s}$ volt a kontaktzónában.

Az ezek alapján 6,3 m/s áramlási sebességre és egy passzra számolt optikai úthosszkülönbséget a IV.4.9. ábrán figyelhetjük meg. A $\Delta d$ görbén is látható, hogy a hőmérséklet-eloszlásnak megfelelően, a hőátadási együttható csökkenése miatt sugárirányban enyhe aszimmetria alakul ki.

\section{IV.4.5. Eredmények kétcsatornás hütés esetére}

A kétcsatornás hűtés alkalmazása a IV.4.2. alfejezet eredményei alapján a hütési teljesítmény jelentős növekedését eredményezi. Ehhez az egycsatornás esetben alkalmazott modellezési eljárást felhasználva, elsőként a $k$ - $\omega$ modellt lefuttatva a kétcsatornás geometria felére, a hosszanti tengely mentén szimmetria peremfeltételt alkalmazva közelítő megoldást nyertem az áramlási paraméterekre. Az egycsatornás esettel megegyező kontaktzónában mérhető áramlási sebességek eléréséhez szükséges bemeneti sebességet állítottam be, a bemeneti peremre merőleges profillal, amely eredményeként kapott sebességeloszlásokat a IV.4.10. ábra szemlélteti. A IV.4.10. ábrán csak a csatorna alsó felét mutatom be, mivel az áramlás a hosszanti tengelyre szimmetrikus. Érdemes megemlíteni, hogy mivel a csatorna 
kétszer nagyobb keresztmetszettel rendelkezik a kontaktzónában, így kétszer akkora bemeneti áramlási sebességre van szükség ugyanazon kristálymenti sebesség eléréséhez, mint az egycsatornás esetben.

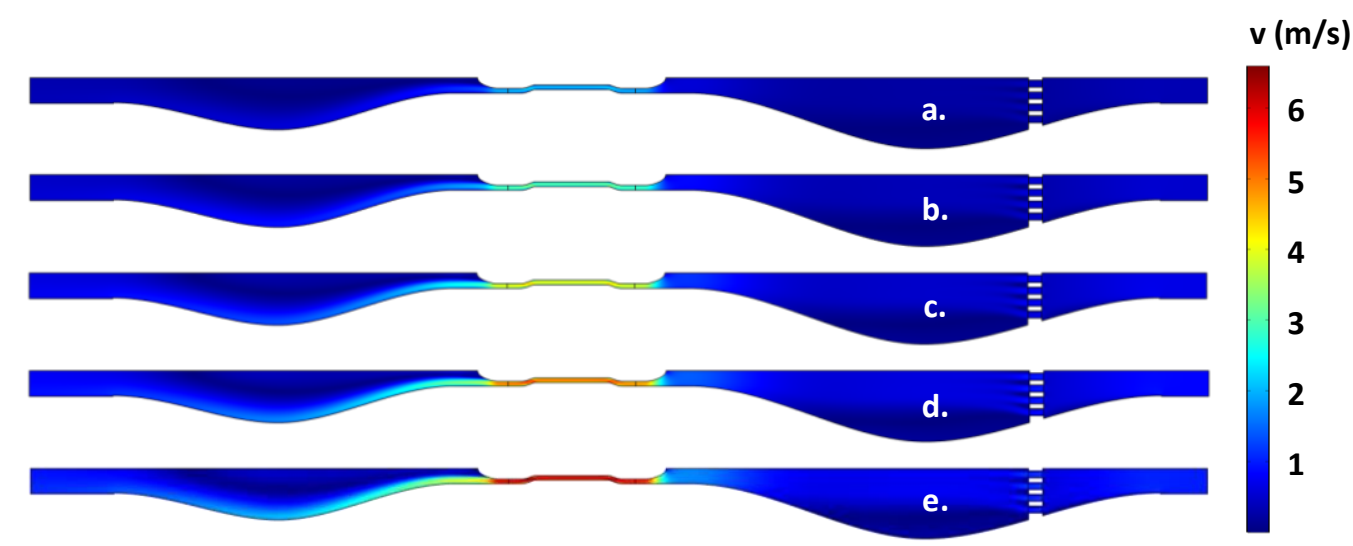

IV.4.10. ábra A k- $\omega$ modellből kapott áramlási sebesség abszolút értékének eloszlása különböző bemeneti sebességek esetén, amelyek megegyeznek az egycsatornás esetben mért bemeneti sebességek kétszeresével.

A $k$ - $\omega$ modell eredményei alapján megadva a kezdeti- és peremfeltételeket, az SST-hőterjedés csatolt modellt is lefuttattam a IV.4.10. ábrán látható bemeneti áramlási sebességeknek megfelelő paraméterekre. Ebből megkaptam a kontaktzóna és közvetlen közelében kialakult stacionárius áramlási sebességeloszlásokat, amiket a IV.4.11. ábra (a-e) része szemléltet.

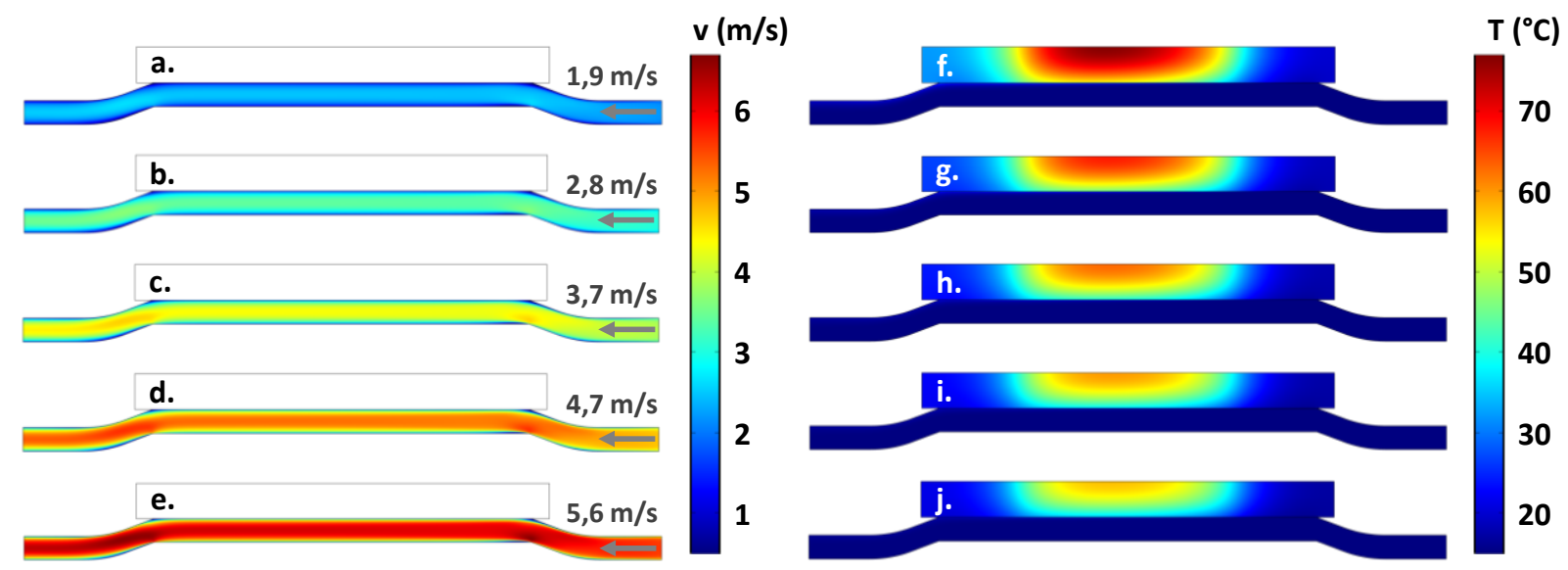

IV.4.11. ábra SST modellből kapott áramlási sebesség abszolút értékének eloszlása az egyik kontaktzónában különböző bemeneti sebességek esetén (a-e), illetve az SST modellhez csatolt hővezetési egyenletek megoldásaként adódott hőmérséklet-eloszlások, a velük egy magasságban vizualizált áramlási sebességeknek megfelelően (f-j) a 6 mm vastag Ti:Sa kristály esetében.

Az áramlás sebességeloszlásaiból ismét jól kivehető, hogy a hütéshez optimális, homogén sebességprofilokat sikerült elérni a kristály közelében. Az ezekhez tartozó hőmérséklet eloszlásokat a $6 \mathrm{~mm}$ vastagságú kristályban és a hütőfolyadékban a IV.4.11. ábra (f-j) részén figyelhetjük meg. A kétcsatornás hütés jelentősen alacsonyabb hőmérséklet-emelkedést eredményez már a legalacsonyabb, 2,2 m/s áramlási sebesség mellett is, ha azonban ezt egészen $6,3 \mathrm{~m} / \mathrm{s}$-ig növeljük, az $42,5^{\circ} \mathrm{C}$-ra csökken a legkisebb sebesség esetén számolt $61,5^{\circ} \mathrm{C}$-ról. A kétcsatornás hütést megvizsgáltam $4 \mathrm{~mm}$ vastag Ti:Sa kristály alkalmazásával is, amellyel az eredmények alapján további jelentős hőmérsékletcsökkenést értem el a kristályban (IV.4.12. ábra) minden áramlási sebességen: 2,2 m/s sebesség esetén mintegy $10,1{ }^{\circ} \mathrm{C}$ hőmérséklet-csökkenést jelentett a kristály vastagságának 4 mm-re változtatása, és ezt a relatív csökkenés az áramlási sebesség $6,3 \mathrm{~m} / \mathrm{s}$-ra való megemeléséig közel meg is marad. Az 
egycsatornás hütés esetén megfigyelhető enyhe aszimmetria a kétcsatornás hütési rendszernél is kivehető a IV.4.11. ábrán, mértéke azonban jóval kisebb a megnövekedett hütési hatásfok miatt.

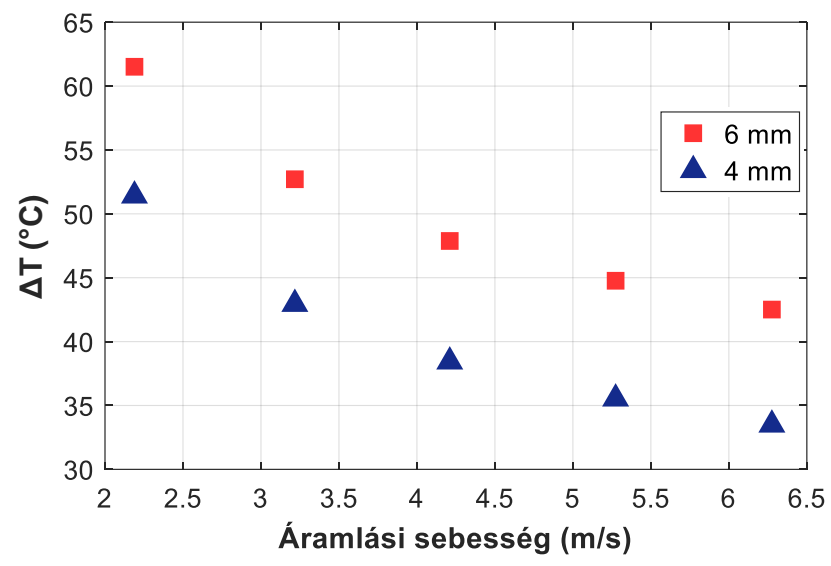

IV.4.12. ábra Hőmérséklet maximális növekedése különböző áramlási sebességek esetén $6 \mathrm{~mm}$ és $4 \mathrm{~mm}$ vastag kristályok esetén.

Összehasonlítva a IV.4.2. alfejezetben két peremen konstans hőmérsékletü modellel a kétoldali folyadékhütéssel nyert eredményeket, az ideálistól való eltérés $6 \mathrm{~mm}$ vastag kristály esetén $6,3 \mathrm{~m} / \mathrm{s}$ folyadéksebesség mellett $5,6^{\circ} \mathrm{C}$, addig $4 \mathrm{~mm}$ vastag kristály esetén pedig csak $3,6{ }^{\circ} \mathrm{C}$ értékü. Az ideális hütéssel kapott eredményhez képest kisebb eltérés a hütés hatékonyságának jelentős megnövekedését prezentálja két csatorna esetén.

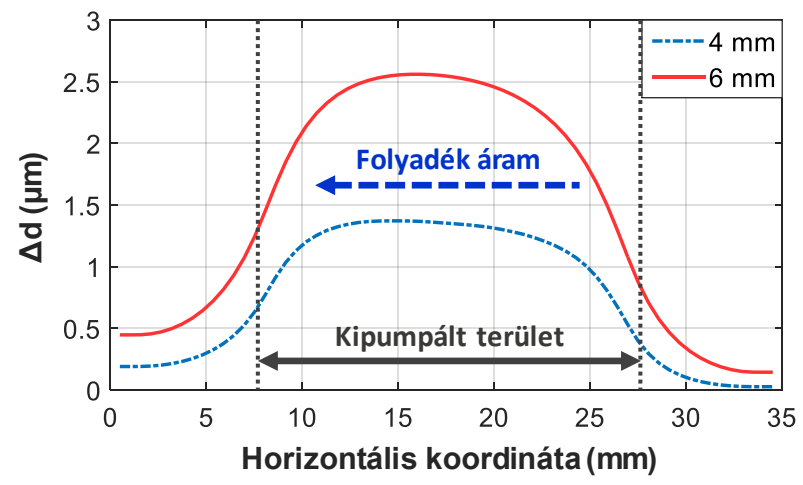

IV.4.13. ábra Optikai úthosszkülönbség a radiális irány mentén a kristályon történő egyszeri áthaladásra $6 \mathrm{~mm}$ (piros) és 4 mm (kék) vastag kristályok esetére. Az áramlási sebesség 6,3 m/s volt a kontaktzónában.

Az optikai úthosszkülönbséget megvizsgáltam a kétcsatornás hütés esetére is. A 6 mm vastag Ti:Sa korongban $6,3 \mathrm{~m} / \mathrm{s}$ áramlási sebességen egyszeri áthaladásra az egycsatornás hütésnél kapott maximális $\Delta d$ értékhez közeli eredményt kaptam, azonban a $\Delta d$ profilja kisebb aszimmetriát mutatott (IV.4.13. ábra, piros görbe). Kiszámolva a $4 \mathrm{~mm}$ vastagságú kristályban kialakult $\Delta d$ görbét egyszeri áthaladásra, a maximális $\Delta d$ érték $1,2 \mu \mathrm{m}$-t csökkent a $6 \mathrm{~mm}$ vastag korong esetéhez képest, valamint a görbe aszimmetriája is kisebb értékü lett. Ebből következően a kisebb vastagságú kristály kétcsatornás hütéssel kombinált alkalmazása a hőmérséklet gradiensének csökkentése, ezáltal a hullámfront torzulásának és a termikus lencse effektus kialakulásának elkerülése szempontjából rendkívül elönyös. A számolások során a két hütőcsatornában áramló hütővízben kialakuló optikai úthosszkülönbséget elhanyagoltam, mivel annak hőmérséklet-változása a relatíve nagy áramlási sebesség miatt alacsony, valamint csupán egy vékony, a kristály felületétől mért mintegy $50 \mu \mathrm{m}$ alatti vastagságú hőmérsékleti határrétegben lép fel. 


\section{IV.4.6. Felskálázási eredmények}

Az egy erősítő csatornából kicsatolható energia, és így a rendszer végén kompresszió után kapott csúcsteljesítmény növeléséhez több pumpaenergiára, valamint nagyobb nyalábátmérőkre és kristály méretre van szükség. Tartva az 1:10 optimális oldalarányt az EDP-TD erősítőben, bár a kristály vastagsága a sugárral lineárisan, a hűtött felület azonban a sugár négyzetével skálázódik, így a hütött felület méretével gyorsan növekszik a hütés hatásfoka is. A kicsatolható energia növelésének hatásait $6 \mathrm{~cm}$ és $20 \mathrm{~cm}$ közötti átmérőjű Ti:Sa korongok esetére vizsgáltam meg, amely során kis mértékben egyszerüsítettem a modellezett csatorna geometriáját.

A hütést kétcsatornás megoldással oldottam meg, míg az optikai sémát transzmissziósnak tételeztem fel. Előbbihez a hűtőcsatorna kialakítását úgy egyszerüsítettem, hogy a csatorna csupán egy egyenes cső alakban kapcsolódik a kristályhoz, törés nélkül. Az áramlás modellezése során továbbra is felhasználtam a $k$ - $\omega$ modellt a kezdeti- és peremfeltételek megadásához, valamint a sebességprofil kifejlődésének eléréséhez a kristályhoz közeli csatornarészhez érve. A hőmérsékletprofil aszimmetriájának csökkentésére a két hütőcsatornában ellentétes irányú folyadékáramlást állítottam be, amely további javulást eredményezett (IV.4.14. ábra). Tekintettel arra, hogy az ilyen hütörendszerekben használt áramlási sebességeknél nagyobb értékre van szükség a kellő hütőteljesítmény eléréséhez, és ennek biztosítása önmagában technológiai kihívás, a modellben beállított kezdeti áramlási sebességet $4 \mathrm{~m} / \mathrm{s}-\mathrm{ra}$ állítottam be. Ezt az áramlási sebességet használtam a további összes modell esetén.

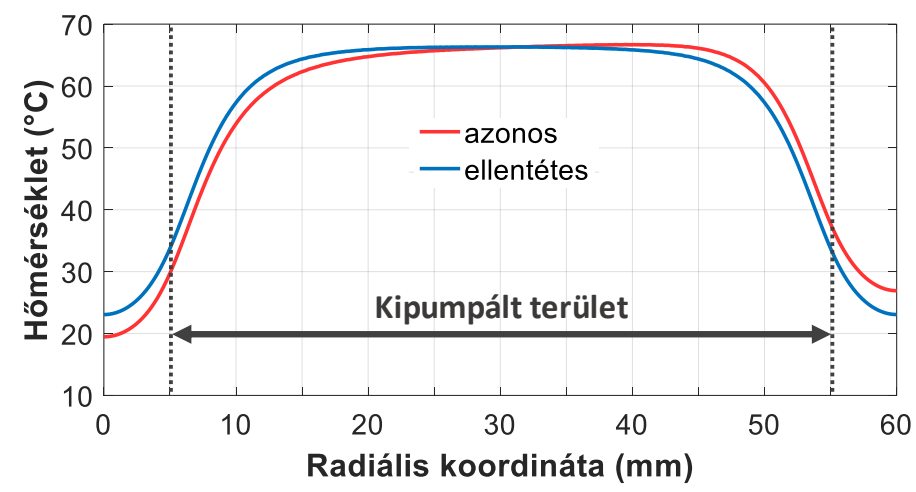

IV.4.14. ábra Hőmérsékletprofilok a kristály központi, hosszanti tengelyén azonos (piros) és ellentétes (kék) irányú folyadékáramlással való hütéssel. A modellezett Ti:Sa kristály $6 \mathrm{~mm}$ x $60 \mathrm{~mm}$ dimenziójú volt.

A pumpaimpulzusok energiáját minden kristályméret esetén úgy növeltem meg, hogy a 100 TW csúcsteljesítményü erősítők esetén előírt $2 \mathrm{~J} / \mathrm{cm}^{2}$ energiasürüséget érjek el a kristályban. A Ti:Sa korong abszorpciós együtthatóját $95 \%$ abszorpció eléréséhez hangoltam minden kristályméret esetén, amelyhez két áthaladást használtam fel mindkét oldali pumpanyaláb esetén. A hütőfolyadék kezdeti hőmérsékletét minden esetben $15^{\circ} \mathrm{C}$-ra állítottam. A nyalábok kristályon való áthaladását figyelembe véve, illetve a lehetséges kristálybefogatásra számolva, a kristály peremétől 5 mm-t elhagytam, azaz a tiszta apertúra $1 \mathrm{~cm}$-rel kisebb a megadott átmérőknél. A pumpálást két oldalról vettem figyelembe. A vizsgált ismétlési frekvenciákon (20, 40, 60, 80 és $100 \mathrm{~Hz}$ ) a hömérséklet kezdeti értékéhez képest bekövetkező megemelkedése $8 \mathrm{~cm}$ kristályátmérőig $60^{\circ} \mathrm{C}$ alatt marad, míg $40 \mathrm{~Hz}$ frekvenciáig még $20 \mathrm{~cm}$ átmérő esetén ( $>0,5 \mathrm{~kJ}$ pumpaenergia) sem nő a hömérséklet-változás $45^{\circ} \mathrm{C}$ fölé, amely esetén a fütőteljesítmény nagyobb mint $10 \mathrm{~kW}$ (IV.4.15. ábra). A hőmérséklet profilja a magasabb ismétlési frekvenciákon is sima marad, amely alacsony hőmérséklet-gradienst biztosít a pumpált terület centruma és szélei között. 


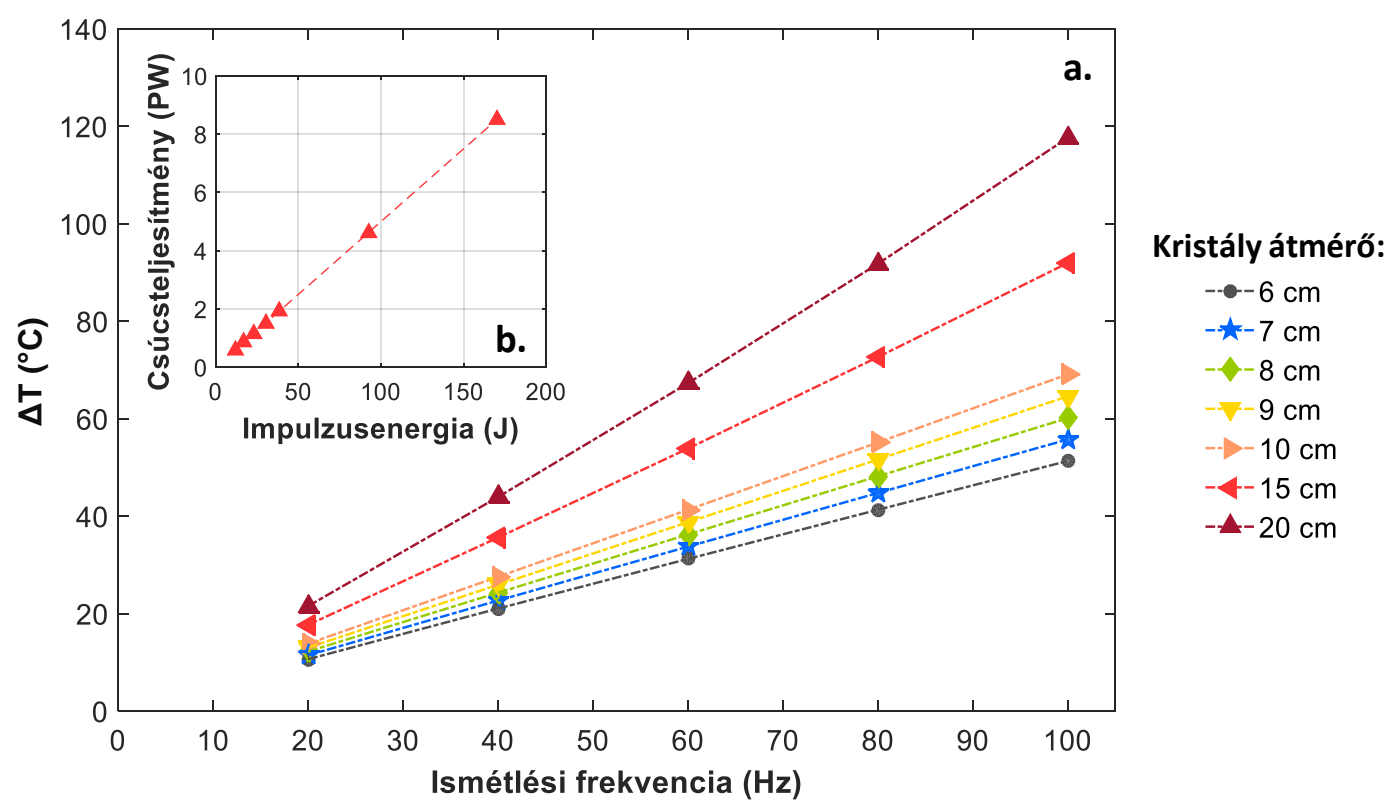

IV.4.15. ábra Hőmérséklet maximális növekedése a hütőközeg hőmérsékletéhez képest adott ismétlési frekvenciákon, különböző kristály átmérök esetén kétcsatornás hütéssel (a). A $6 \mathrm{~cm}$ átmérőtől kezdve a pumpaenergiák a következöek: 40 J, 57 J, 77 J, 101 J, 127 J, 308 J és 567 J. Kompresszált impulzusok csúcsteljesítménye az egyes kristályátmérőkre (b), ahol 60\% impulzuskompresszor hatásfokot és $20 \mathrm{fs}$ impulzushosszt tételeztem fel.

A 100 TW-nál nagyobb csúcsteljesítményü impulzusok előállításához szükséges kristályméretek esetén felmerül annak lehetősége, hogy megnöveljük a hütőcsatornák számát a következő módon. Ha a kristály vastagsága nagyobb vagy egyenlő mint $6 \mathrm{~mm}$, kísérleti tapasztalataim alapján lehetséges a kristály két egyenlő részre vágásával azok befogatása. Ekkor a két egyenlő vastagságú kristályt mindkét oldalról hütve egy három csatornás rendszert kapunk. Ezzel a módszerrel az egy kristályra jutó fütőteljesítményt megfelezhetjük, valamint a hütött felületet jelentősen megnövelhetjük. A két kristály pumpálása az egy kristályt tartalmazó erősítővel azonos módon, két oldalról valósítható meg, csupán a nyaláboknak át kell haladnia mindhárom hütőfolyadék csatornán. Ez reflexiós veszteségekhez, valamint hullámfront torzulásokhoz vezethet, azonban ezeket a pumpaenergia néhány százalékos megnövelésével, illetve az erősítő után beépített deformálható tükörrel kompenzálhatjuk. A kristály méreteinek további növelése a csatornák és az erősítő kristály korongok számának további növelését is lehetővé teszi. Ezt a módszert több esetben alkalmazták az utóbbi években, például Nd:YLF kristály alapú koronglézerekben [198], de hasonló multi-slab elrendezést használnak a DiPOLE és DiPOLE-100 Yb:YAG végerősítő fokozataiban is [199,200]. A kristályok két oldalán lévő csatornákban a hủtőfolyadék áramlását egymással ellentétesre állítottam, javítva ezáltal a hőmérsékletprofil szimmetriáját a korongokban. A Ti:Sa korongok abszorpciós együtthatóját úgy hangoltam, hogy kétpasszos kétoldali pumpálással 95\% abszorpciót érjek el a két kristályra együttesen. Az ilyen típusú, kétkristályos erősítő modulok potenciáljának demonstrációjára $100 \mathrm{~Hz}$ ismétlési frekvencián vizsgáltam a hőmérséklet változását. A középső hütőcsatorna hosszanti tengelye szimmetriatengelyként szolgált, így elegendő volt a teljes geometria felét modelleznem. Négy erősítő modult szimuláltam, mégpedig 6, 10, 15 és 20 cm átmérőjü és 3, 5, 7,5 és 10 mm vastagságú kristályokkal (IV.4.16. ábra). A IV.4.16. ábra alapján kijelenthető, hogy a kristály két részre vágásával, és három hủtőcsatorna alkalmazásával jelentősen csökkenteni tudtam a kristályokban kialakuló hőmérséklet-gradiens, valamint a hőmérséklet profilja is rendkívül előnyös módon változott. 


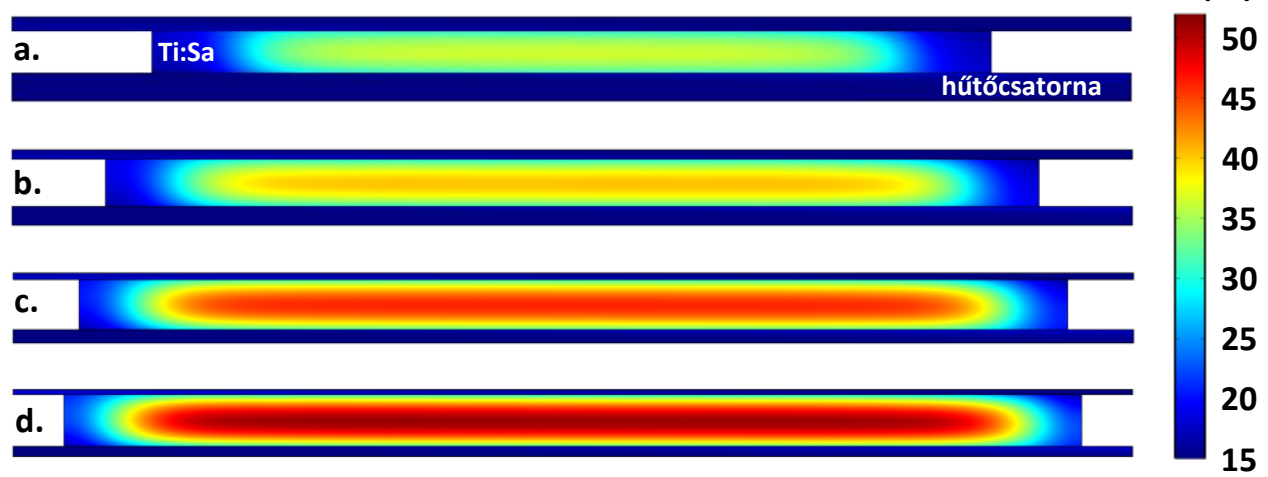

IV.4.16. ábra Hőmérséklet-eloszlás a modellezett geometriában $6 \mathrm{~cm} \times 0,3 \mathrm{~cm}$ (a), $10 \mathrm{~cm} \times 0,5 \mathrm{~cm}$ (b), $15 \mathrm{~cm}$ x $0,75 \mathrm{~cm}$ (c) és $20 \mathrm{~cm}$ x $1 \mathrm{~cm}$ (d) méretü kristályokra.

Érdemes összehasonlítani az egy kristállyal, illetve a dupla kristállyal szerelt erősítő modulok termikus viszonyait (IV.4.17. ábra).

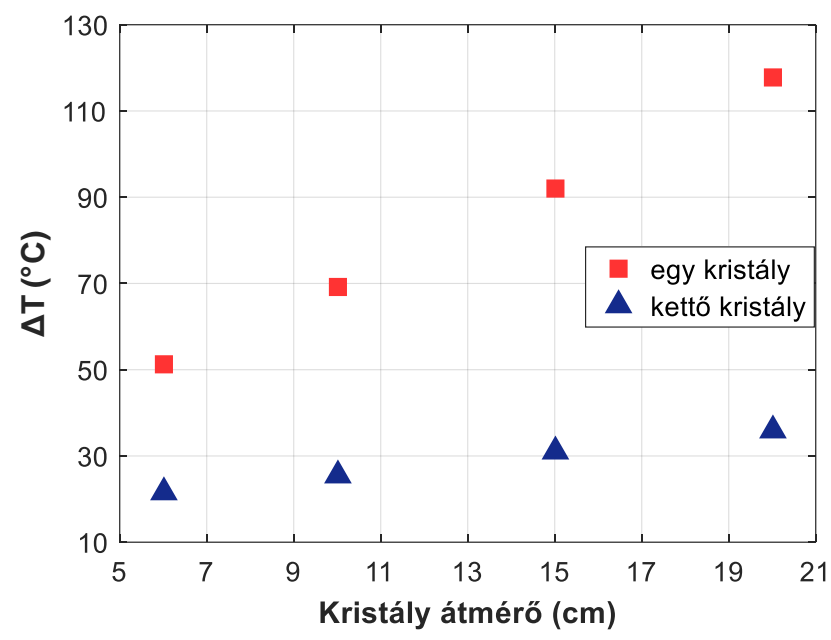

IV.4.17. ábra Hőmérséklet emelkedése egy- (piros) és két kristályból (kék) álló erősítő fejre, különböző kristály átmérők esetén.

Míg a $6 \mathrm{~mm}$ x $60 \mathrm{~mm}$ kristályt tartalmazó modulban a hőmérséklet kezdeti értékéhez képest bekövetkező megváltozása $51,3{ }^{\circ} \mathrm{C}$, addig kettévágva a kristály és megnövelve a hütőcsatornák számát ez az érték $21,5^{\circ} \mathrm{C}$-ra csökken. Ha növeljük a kristály átméröjét, bár jelentősen nő a fütőteljesítmény is, és egy kristályt tartalmazó modullal a hőmérséklet $117,7^{\circ} \mathrm{C}$-t emelkedik a kezdeti értékhez képest, addig két kristállyal ez az érték a szimulációk szerint csupán $36,1^{\circ} \mathrm{C}$ egy $20 \mathrm{~mm}$ x $200 \mathrm{~mm}$ méretű korong esetén, amely mintegy $81,6^{\circ} \mathrm{C}$ csökkenést jelent. Ezek az eredmények egyértelmúen prezentálják a multikorong erősítő modulok potenciálját. Fontos azonban megemlíteni, hogy amennyiben a törésmutató illesztett folyadékban feloldott abszorber helyett szilárd, például kerámia típusú abszorbert tudnánk használni a Ti:Sa kristály peremén, jelentősen leegyszerüsítené a kristály rögzítésének és a hủtőcsatornák vezetésének kialakítását. Ez a módszer utat nyithat a több kristályt tartalmazó EDP-TD erösítő modulok kialakításához.

\section{IV.4.7. Modell összehasonlítása a kísérleti eredményekkel}

A IV.3.5. alfejezetben ismertetett kísérlet során mért egyensúlyi hőmérséklet-eloszlást összehasonlítottam a kísérleti paraméterek alapján felépített, geometriáját tekintve egyszerüsített numerikus modellel két- és háromdimenziós esetben is. A modell a Ti:Sa kristályból, valamint egy azzal 
közvetlenül érintkező $10 \mathrm{~mm}$ vastagságú, téglatest alakú csatorna részletből állt. A csatornarészlet bemenetén $0,3 \mathrm{~m} / \mathrm{s}$ áramlási sebességet állítottam be homogén eloszlással. Ez a bemeneti sebesség éppen a kísérletek során alkalmazott azonos csatornavastagság mellett mért $0,35 \mathrm{~m} / \mathrm{s}$ áramlási sebességet eredményezett a kristállyal való érintkezési zónában a csatorna középső részén, amelyben a mérés is el lett végezve. Az abszorbeált pumpaenergia hődisszipációs hatásfokára a magimpulzusokkal való energiakicsatolás hiányát, a kvantum defektust és a vizsgált hőmérsékleten érvényes kvantum hatásfokot figyelembe véve 0,468 értéket állítottam be a modellben. Tekintettel arra, hogy a kísérlet során a hütővíz áramlása lamináris volt, a problémát megvizsgáltam mind a lamináris, mind pedig az SST turbulens folyadékáramlási modell segítségével.

Az hütővíz áramlását mind a lamináris, mind pedig az SST modell segítségével a hőterjedési problémával csatolva kiszámoltam. A kétdimenziós esetben a lamináris modellel $3,7^{\circ} \mathrm{C}$, az SST modellel számolva pedig mintegy $3,1^{\circ} \mathrm{C}$ értékkel nagyobb csúcshőmérsékletet nyertem a mért értékekhez képest, valamint a mérthez hasonló profilt kaptam a kísérleti paraméterek mellett. Az eltéréseket az áramlásra merőleges irányú hőterjedés kétdimenziós esetben való hiánya eredményezi. Átváltva a háromdimenziós szimulációkra, az eredményeket a IV.3.5. alfejezetben leírt mérésből kinyert horizontális profillal összevetve a IV.4.18. ábra (a) része mutatja.
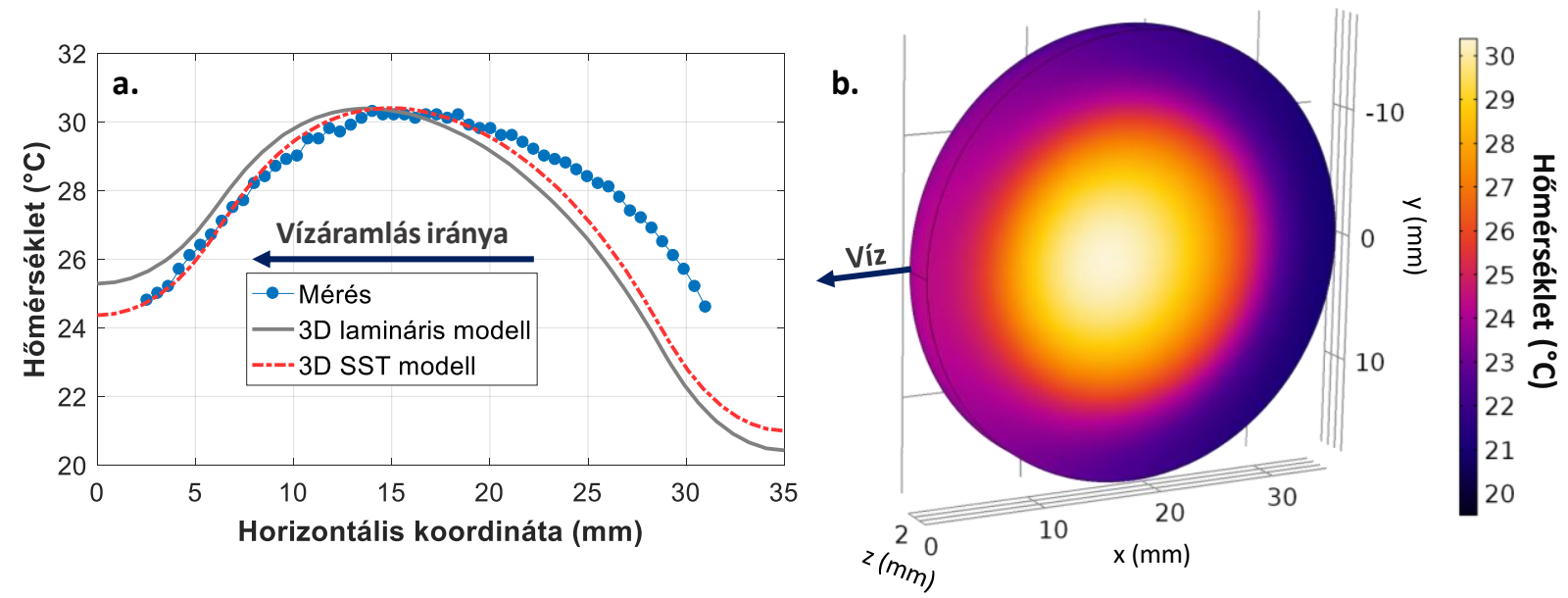

IV.4.18. ábra Mért (kék karika) és háromdimenziós lamináris (szürke folytonos vonal), valamint háromdimenziós SST modellel (piros szaggatott vonal) kapott horizontális hömérsékletprofil a $4 \mathrm{~J}$ energiával $10 \mathrm{~Hz}$ ismétlési frekvencián pumpált Ti:Sa kristály esetére (a). Háromdimenziós hőmérséklet-eloszlás a kristály elülső és oldalsó felületén az SST modellel számolt áramlás esetére (b). A háromdimenziós hőmérsékleteloszlás méréssel való összehasonlításának megkönnyítése érdekében a mért profillal azonos színkódolást használtam.

A két modell közül az SST típusú ad jobb egyezést a mért értékekkel, amely oka az lehet, hogy az áramlási csatorna falához közel ez a modell pontosabban határozza meg a sebességeloszlást. A stacionárius hőmérséklet-eloszlás csúcsát mindkét modell jól visszaadja. Ugyanakkor, mindkét modell esetén a jobb szélen alacsonyabb a számolt hőmérséklet, mint a méréssel kapott érték. Ennek oka valószínüleg a pumpaimpulzusok által gerjesztett TPG folyamat kristály szélén található abszorberben való elnyelődése, amely melegíti azt, és így a kristály peremén addicionális hőterhelés jelentkezik. A TPG folyamat kialakulásának pontos modellezése igen bonyolult, és több lézerparaméter további mérését igényelné, így erre a kalkulációim során nem került sor. A IV.4.18. ábra (b) részén ábrázolt, a kristály felületén kapott háromdimenziós hőmérséklet-eloszlást összevetve a IV.3.12. ábra (e) részén látható mért eloszlással jó egyezés figyelhető meg. Megvizsgálva a kristály középvonalai mentén a horizontális és a vertikális irányú hőmérséklet-eloszlást a IV.4.19. ábrán látható értékeket kaptam. 


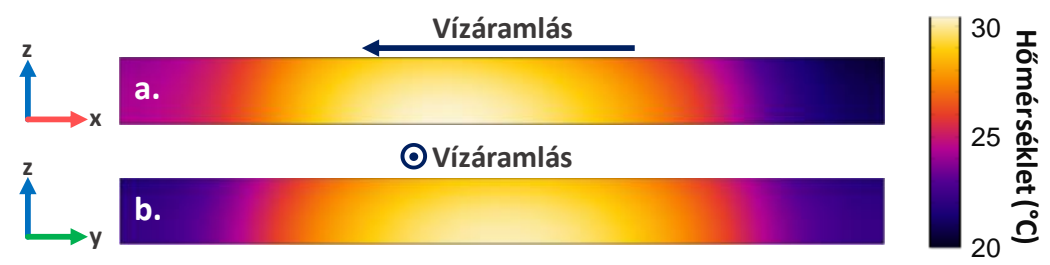

IV.4.19. ábra Háromdimenziós SST modellel kapott kétdimenziós hőmérséklet-eloszlások a kristály horizontális (a) és vertikális irányú (b) metszeteiben, a középvonalak mentén. A hủtővíz áramlási iránya a (b) esetben a lap síkjából kifelé mutat.

A Ti:Sa kristály horizontális metszetében a vízáramlás irányában enyhe aszimmetria figyelhető meg a hőmérséklet eloszlásában, azonban a hőmérséklet a kristály vastagsága mentén közel állandó. Ezzel szemben a vertikális metszetben szimmetrikus hőmérséklet-eloszlást kapunk. A szimulált hőmérsékleteloszlásban a kristály szélen kapható jelentős eltérés a mérésből nem látható, mivel a kristály széleit a befogatás eltakarja. A mért és a szimulált profilok közötti eltérés további forrása lehet még, hogy a kísérlet során az áramlás a kristály befogatásának egyenetlenségei miatt nem volt kellően sima, így a modell a hütést a kristály szélein túlbecsülte. Erre az effektusra a 100 TW / 100 Hz paraméterü erősítő fejek szimulációi során külön figyelmet fordítottam. Ezen felül, a pumpaimpulzusok térbeli intenzitásprofilja némi eltérést mutatott a szélek között, ami szintén eredményezhet eltérést a szimulációban figyelembe vett Super-Gauss eloszlású intenzitásprofilhoz képest. A vertikális hőmérséklet-profil a hőkamera szög alatti leképezése miatt torzult, illetve a kristály alsó szélét a befogatás takarja, azonban a kristály felső részén jó egyezés látható a háromdimenziós szimulált eloszlással.

\section{IV.4.8. Diszkusszió}

A IV.3. alfejezetben tárgyalt eredményekre alapozva, az EDP-TD erősítők felskálázásával kapcsolatos, részletes numerikus szimulációk váltak szükségessé. Ehhez a COMSOL Multiphysics szoftver optimális választásnak bizonyult. A szobahőmérsékletü üzemeltetés számos előnye miatt vízhütéses erősítő modulok modellezésére koncentráltam. Ehhez a hőterjedést, valamint a hủtőközeg áramlását leíró differenciál-egyenleteket kellett csatolva megoldanom. Kétdimenziós numerikus modellt építettem FEM módszerrel, amelyben mindkét problémát stacionárius esetre oldottam meg.

Megvizsgáltam egy $100 \mathrm{TW} / 100 \mathrm{~Hz}$ osztályú végerősítő modulban kialakuló stacionárius hőmérséklet-eloszlást, amelyhez egy-, illetve kétcsatornás hütési elrendezéseket használtam fel. Az egycsatornás hütés esetén az aktív tükör geometriát használva egy $3 \mathrm{~mm}$ vastag Ti:Sa kristályra számoltam ki a hőmérséklet eloszlását $6 \mathrm{~J}$ pumpálásra vonatkozóan, $50 \%$ erősítéssel való energiakicsatolási hatékonyság mellett. A kétcsatornás hütés esetében 6 és $4 \mathrm{~mm}$ vastag Ti:Sa koronggal számoltam, az egycsatornás hütésnek megfelelő lézerparaméterek mellett. Mindkét hütési koncepció esetén multipasszos pumpálást alkalmazva 95\% abszorpciót értem el. A hütést a folyadékáramlás sebességének változtatásával optimalizáltam. Az eredmények alapján elmondható, hogy a $100 \mathrm{~Hz}$ ismétlési frekvencián való erősítéshez az egycsatornás hütés mellett $91{ }^{\circ} \mathrm{C}$ feletti hőmérsékletnövekedés kapható a pumpált térfogat centrumában. Ezzel szemben a kétcsatornás hütéssel és a $4 \mathrm{~mm}$ vastag Ti:Sa kristállyal ez az érték $35^{\circ} \mathrm{C}$ alá csökkenthető. A kristályban kialakuló stacionárius hőmérsékletprofil alapján meghatároztam a törésmutató hőmérsékletfüggéséből származó optikai úthosszkülönbséget is, amellyel arányos az erősített impulzus hullámfront torzulása.

Szimulációkat végeztem a 100 TW-nál nagyobb csúcsteljesítményü impulzusok előállítására alkalmas végerősítők hűtésére vonatkozóan, amely során két koncepciót követtem. Elsőként 
kétcsatornás hütéssel és transzmissziós optikai sémával vizsgáltam a megnövelt energiájú EDP-TD erősítők termikus müködését. A második esetben kétkristályos erősítő fejeket modelleztem, ahol a hűtőcsatornák számát háromra növeltem. A szimulációs eredményekből egyértelműen kiolvasható, hogy az átlagteljesítmény nagymértékü felskálázásához a többkristályos, többcsatornás hütés alkalmazása még hatékonyabb megoldás lehet. Felmerül ugyanakkor a kérdés, hogy a hütőfolyadékon való áthaladás mind a pumpa, mind pedig az erősített impulzusok esetén addicionális hullámfront torzulásokat eredményezhet. Ezen effektusok vizsgálata a jövőben mindenképpen szükségszerü.

Az általam épített, a folyadékáramlást és hőterjedést csatolt módon tartalmazó FEM modellt a kísérleti eredményekkel összevetve mind a lamináris, mind az SST áramlási modellt alkalmazva jó egyezést kaptam. A mért eredményekhez az SST áramlási modellel számolt értékek álltak közelebb. A mért értékektől való minimális eltérést a pumpa intenzitásprofiljának optimálistól deviációja, nem tökéletes centráltsága a kristályban, valamint a TPG elnyelődése révén a kristály szélén lévő abszorber melegedése. A háromdimenziós modell kísérleti eredményekkel való egyezése azonban meggyőző, s megmutatta a modell kiváló alkalmazhatóságát a korongerősítők hütésének szimulációjára.

A korong típusú erősítés Ti.Sa közegen alapuló, reflexió és transzmissziós elrendezésekben való alkalmazhatóságát a kétdimenziós szimulációk eredményesen alátámasztották. Igazán pontos eredményeket háromdimenziós modellezéssel kaphatunk, amelyhez a konkrét geometria ismerete alapvető fontosságú. Fontos megjegyezni, hogy a kétdimenziós modellek esetén a módosításokkal kapcsolatos rugalmasság, a kisebb számítási teljesítmény- és időigény jelentősen megnöveli a felhasználhatóságot. Mivel a háromdimenziós modellek számítási- és időigénye többszöröse a kétdimenziós eseteknek, így az előbbieket leginkább a végső geometria ismeretében szokás alkalmazni. A közeljövőben a HF-100 lézerrendszer architektúrájának pontosítását követően a jelenleginél részletesebb, a parazita effektusokat is figyelembe vevő háromdimenziós szimulációkat fogok készíteni az erősítő modulokban kapható hőmérséklet-eloszlások meghatározására.

T4.a. Kétdimenziós numerikus modellezést végeztem a HF-100 lézer egy lehetséges, $100 \mathrm{TW}$ osztályú EDP-TD Ti:Sa végerősítőjének hűtésére vonatkozóan. Egy- és kétcsatornás hütési elrendezéseket megvizsgálva azt kaptam, hogy kétcsatornás hütés esetén $4 \mathrm{~mm}$ vastag kristállyal a hőmérséklet maximális emelkedése $35^{\circ} \mathrm{C}$ értékre csökkenthető [TP5].

T4.b. Nagyobb csúcsteljesítményü EDP-TD erösítőket vizsgáltam meg 8,5 PW szintig, különbözö ismétlési frekvenciákon. Kétkristályos és három hütőcsatornás elrendezést alkalmazva tovább növeltem a hütés hatásfokát, amely több kW átlag-, és több PW csúcsteljesítményü rendszerek végerősítőinek megvalósítását teheti lehetővé [TP5]. 


\section{V. Összefoglalás}

A nagyintenzitású fényimpulzusok előállítására napjainkban leginkább Ti:Sa alapú CPA és DCPA rendszereket alkalmaznak. Ennek oka, hogy a Ti:Sa erősítö közeg kiváló fizikai tulajdonságai, valamint rendkívül széles emissziós spektruma lehetővé teszi az akár több PW csúcsteljesítményü és 25 fs hosszúságú impulzusok létrehozását. A Ti:Sa technológia két legfőbb limitációja a 25 fs alatti hosszúságú impulzusok előállítása, illetve a nagy átlagteljesítmény elérése. Az előbbi probléma a Ti:Sa erősítési spektrumának alakjára és véges szélességére vezethető vissza, amely az erősített impulzusok spektrumának beszükülését és eltolódását eredményezi. Az utóbbi korlátot a lézererősítés folyamata során a pumpanyaláb abszorpciójából disszipált hő eredményezi. Nagy átlagteljesítményü pumpálás esetén ugyanis a kristály pumpált térfogatában jelentős hőmérsékleti gradiens jön létre, amely az erősített impulzusok térbeli profiljának torzulásához, végső soron az erősítő közeg és a lézerrendszer optikáinak sérüléséhez vezethet. Nagy csúcsteljesítményü lézerrendszerekben a végerösítök kristályaiban már $10 \mathrm{~Hz}$ ismétlési frekvencia esetén is több tíz watt hőteljesítmény disszipálódik, amely az erősítő átlagteljesítményének felskálázását jelentősen korlátozza.

A Ti:Sa lézererősítőkben a kristály hütését mérsékelt átlagteljesítményü pumpálás esetén szobahőmérsékleten, vízzel szokás megoldani. Fontos azonban, hogy a gerjesztett kristály az erősített impulzusok CEP-jére hatást fejthet ki, és így a lézerparaméterektől függően leronthatja annak stabilitását. Nagy átlagteljesítményü pumpálás esetén az erősítő kristályt alacsony hőmérsékletre szokás hüteni, amely révén a hővezetési együttható Ti:Sa esetén ugrásszerủen megnő, jelentősen mérsékelve ezáltal a hőmérsékleti gradienst a pumpált térfogatban. Mivel azonban az optikai és lézerparaméterek is megváltoznak ezen a hőmérsékleten, az erősítés spektrális fázisra és CEP-re kifejtett hatása a szobahőmérsékletű müködéstől egészen különböző lehet. CPA rendszerek esetén az erősített impulzusok fázisstabilitása számos kísérlet szempontjából kritikus lehet, emiatt az erősítés során fellépő fázisinstabilitások részletes vizsgálata szükséges.

Értekezésemben a Ti:Sa erősítő rendszerekben fellépő fázis instabilitásokkal, valamint az átlagteljesítmény felskálázását lehetővé tevő korongerősítő koncepcióval kapcsolatos új eredményeimről számoltam be. Eredményeim nagy mértékben elősegíthetik a jelenleg elérhető nagyintenzitású lézerek fázisstabil és nagy átlagteljesítményü müködést biztosító továbbfejlesztését. Eredményeim az ELI-ALPS HF-100 lézerrendszerének tervezéséhez és megvalósításához szükséges kutatás-fejlesztési projekt részét képezik.

Tudományos eredményeimet az alábbi tézispontokban foglalom össze:

T1. Megvizsgáltam a vízhütéses Ti:Sa erősítés CEP-stabilitását a lézerparaméterek függvényében. A CEP csúszására egységnyi hőmérséklet-változásra, a kristály hosszára normalizálva $11 \mathrm{mrad} /{ }^{\circ} \mathrm{C} / \mathrm{mm}$ értéket mutattam ki. Megállapítottam, hogy az erősített impulzusok CEP-zaja a pumpaenergiával lineárisan növekszik, míg az ismétlési frekvenciával exponenciális jelleggel csökken. A magimpulzusok energiája a CEP csúszására és zajára a mérés érzékenységén belül nem volt hatással [TP1].

T2.a. Meghatároztam egy kriogenikus hütésű Ti:Sa erősítő spektrális fáziszaját a vákuum-, illetve a hűtőrendszerek müködési szakaszainak függvényében. A vákuum-, és a kriogenikus rendszerek spektrális fáziszaj járulékára is 50 mrad RMS körüli értéket kaptam [TP2]. A spektrális fázis zajspektrumát összehasonlítottam az optikai elrendezés mechanikai rezgéseinek frekvenciaeloszlásával, amely alapján azonosítottam a főbb zajforrásokat. 
T2.b. Megmértem az erősített impulzusok spektrális fáziszaját az ismétlési frekvencia függvényében. Meghatároztam a CEP termikus és mechanikai eredetủ zajának statisztikai eloszlásait. A termikus eredetü CEP-zajra 12 mrad RMS alatti, addig a mechanikai eredetü fáziszajra $1 \mathrm{mrad}$ alatti értékeket kaptam [TP2].

T3.a. TD geometria alkalmazását javasoltam az EDP módszerrel kombinálva nagyenergiájú Ti:Sa végerősítők átlagteljesítményének felskálázásához. Numerikus szimulációkkal összehasonlítottam egy konvencionális és egy EDP-TD technikával müködtetett 2 PW csúcsteljesítményü erősítő termikus hatásait. Az EDP-TD erősítő esetén jelentős javulást mutattam ki a hőmérséklet eloszlásában [TP3].

T3.b. Kísérletileg demonstráltam egy 100 TW osztályú EDP-TD Ti:Sa végerősítő fokozat müködését. Egylövéses kísérletekkel $5 \mathrm{~J}$ abszorbeált pumpaenergia és $0,5 \mathrm{~J}$ magimpulzus energia mellett 2,6 J erősített impulzusenergiát értem el [TP4]. A Ti:Sa kristályban kialakuló hőmérsékletet 4 J energiájú impulzusokkal $10 \mathrm{~Hz}$ ismétlési frekvencián vizsgálva egyenletes térbeli eloszlást tapasztaltam, és a hőmérséklet maximumára $30,3{ }^{\circ} \mathrm{C}$-ot kaptam. Megmértem a kristályban pumpálás esetén fellépő hullámfront torzulást a kristályon való kétszeri áthaladásra.

T4.a. Kétdimenziós numerikus modellezést végeztem a HF-100 lézer egy lehetséges, $100 \mathrm{TW}$ osztályú EDP-TD Ti:Sa végerősítőjének hütésére vonatkozóan. Egy- és kétcsatornás hütési elrendezéseket megvizsgálva azt kaptam, hogy kétcsatornás hűtés esetén $4 \mathrm{~mm}$ vastag kristállyal a hőmérséklet maximális emelkedése $35^{\circ} \mathrm{C}$ értékre csökkenthető [TP5].

T4.b. Nagyobb csúcsteljesítményü EDP-TD erösítőket vizsgáltam meg 8,5 PW szintig, különböző ismétlési frekvenciákon. Kétkristályos és három hủtőcsatornás elrendezést alkalmazva tovább növeltem a hütés hatásfokát, amely több kW átlag-, és több PW csúcsteljesítményü rendszerek végerősítöinek megvalósítását teheti lehetővé [TP5]. 


\section{Summary}

\section{VI.1. Introduction}

The rise of solid-state lasers paved the way for the generation of femtosecond ( $\left.1 \mathrm{fs}=10^{-15} \mathrm{~s}\right)$ pulses with unprecedented peak intensities. Ti:Sapphire (Ti:Sa), which was first demonstrated as a laser active medium more than three decades ago, is still used in most of the laser amplifier systems capable of generating electromagnetic pulses with few tens of fs pulse duration and peak powers up to the PW $\left(1 \mathrm{PW}=10^{15} \mathrm{~W}\right)$ level. One of the main application areas of high energy femtosecond pulses is the generation of attosecond $\left(1 \mathrm{as}=10^{-18} \mathrm{~s}\right)$ pulses via high order harmonic generation inside gaseous or from solid-state media. To obtain these extremely short light wave packets, the driving field, i.e. the femtosecond laser pulse has to be controlled not only in amplitude, but in phase, too. More precisely, the spectral phase and part of it, the carrier-envelope phase (CEP) of few-cycle pulses has a huge impact on the generation process of isolated attosecond pulses, and on the outcome of many light-matter interactions. If the phase changes in a pulse-to-pulse nature, the instability can lead to the failure of the given experiment. Environmental conditions are significantly affecting the operation of the laser system, and thus the pulse parameters, which can vary on different time scales. Accordingly, the usability of amplified femtosecond pulses highly depends on the stability of the pulse parameters, which are delivered to the target.

Ti:Sa based CPA and DCPA systems suffer from two major issues. The available compressed pulse duration tends to be limited to around $25 \mathrm{fs}$ after compression, which is caused by the narrowing and shifting of the amplified pulse spectrum. The other limitation exists in the scaling of output average power. The heat deposition in the laser gain medium is a serious technological issue, which scales with the average power of the pump pulses. The temperature gradient in the pumped volume of the crystal distorts the spatial profile of the amplified pulses, which can lead to damages of the gain medium or the optical components in the laser system. In high energy Ti:Sa laser systems, even at $10 \mathrm{~Hz}$ repetition rate the amplifiers can produce tens of watts average power pulses, which leads to the same amount of heat deposited in the gain medium. This means, that scaling up of the operation of the laser system requires highly efficient cooling schemes to be realized.

The results presented in this thesis are part of the development work devoted to the HF-100 arm of the High Field Laser of the ELI-ALPS Research Institute. The HF-100 system is planned to provide CEP stabilized pulses with $0.5 \mathrm{~J}$ of energy, $10 \mathrm{fs}$ temporal duration at $100 \mathrm{~Hz}$ repetition rate. To produce such particular pulse parameters, the currently available Ti:Sa technology needs to be significantly improved in three major points. Firstly, the CEP drift and noise contribution of Ti:Sa amplifiers needs to be precisely identified and controlled. Secondly, the cooling efficiency of currently available amplifier heads has to be significantly improved. Finally, the gain narrowing effect, which limits the available pulse duration by decreasing the bandwidth of amplified pulses, needs to be compensated. This thesis concentrates on the first two points, which were addressed about the improvement of the current Ti:Sa amplification schemes.

The aims of this thesis were to characterize the carrier-envelope phase instabilities originating from Ti:Sa amplifiers operated at room and cryogenic temperatures. Furthermore, the operation of the first thin disk 100 TW class Ti:Sa amplifier was demonstrated at room temperature. Finally, the results of numerical simulations on $100 \mathrm{TW}$ class Ti:Sa thin disk amplifiers operating at $100 \mathrm{~Hz}$ repetition rate, and the upscaling of the thin disk Ti:Sa amplification are presented. The experimental work presented 
in this thesis was performed in the TeWaTi Femtosecond Laser Laboratory of the Department of Optics and Quantum Electronics of the University of Szeged (Szeged, Hungary), and in the Max-Born-Institute for Nonlinear Optics and Short Pulse Spectroscopy (Berlin, Germany). The numerical modeling was conducted by using the computational infrastructure and software licenses of the ELI-ALPS Research Institute (Szeged, Hungary).

\section{VI.2. Objectives}

CEP stability of intense few cycle laser pulses is crucial for many applications, especially for isolated attosecond pulse generation, coherent beam combination and ultraprecise frequency metrology. The contributions of individual subsystems to the CEP instability in a high peak power laser system have been investigated in a few cases, only. In case of diffraction grating based stretcher-compressor pairs it was shown, that mechanical vibrations can induce CEP fluctuations on a shot-to-shot basis. Noncollinear optical parametric amplification in an OPCPA system has been also studied before, in which the amplifier was also shown to have significant CEP noise contribution. However, no study has ever been conducted on the CEP fluctuations due to chirped pulse Ti:Sa amplifier stages. The precise knowledge of the CEP drift and noise in a Ti:Sa amplifier would be highly beneficial for the design and implementation of phase stable high peak power laser systems. Also, it is extremely important to understand, what physical effects can contribute to the phase instabilities during the amplification process.

C1. The first aim of my thesis was to investigate the CEP drift in the crystals of water-cooled Ti:Sa amplifiers. I will determine the effects of laser amplification on the CEP, experimentally. Furthermore, I will determine the effects of cooling instabilities of the gain medium on the CEP of the amplified pulses.

High average power operation based on Ti:Sa amplification often requires extreme cooling solutions to eliminate spatial distortion effects of the amplified pulses, like thermal lensing, which can lead to damages of the optical components, including the gain medium itself. It is well known, that by decreasing the temperature of solid-state laser materials, one can benefit from the significantly improved thermal properties of these media. In case of Ti:Sa, the thermal conductivity increases to around $1000 \mathrm{~W} /(\mathrm{m} \cdot \mathrm{K})$ at $77 \mathrm{~K}$, while if we decrease the temperature to around $30 \mathrm{~K}$, this value can be as high as $1.6 \cdot 10^{4} \mathrm{~W} /(\mathrm{m} \cdot \mathrm{K})$. The application of cryogenic cooling to solid-state laser materials brought significant improvement in the output average power. However, the application of cryogenic temperature necessitates the use of vacuum systems to avoid the condensation of water and contaminations of air on the amplifier crystal. The refrigerator and the vacuum systems can bring severe amount of mechanical vibration to the optical setup, which can destroy the phase stability of the amplifier system.

C2.a. I will investigate the effects of amplification on the spectral phase noise in a cryogenically cooled Ti:Sa amplifier. I will determine the spectral phase noise contributions of the vacuum and cryogenic systems. Also, I plan to identify the noise sources of mechanical origin in the different operational stages of the amplifier.

C2.b. I will determine the thermally and mechanically originated CEP noise contributions of the Ti:Sa amplifier. Moreover, I will investigate the statistical distribution of the CEP noise of amplified pulses for different repetition rates of operation. 
Ultrahigh peak power pulses in the $100 \mathrm{TW}$ - PW regime can be reached with the application of large aperture laser crystals. However, by increasing the aperture of the gain media, the gain along the transversal direction (i.e. perpendicular to the beam propagation direction) tends to be higher than along the longitudinal direction. This leads to the rise of parasitic effects, like transverse parasitic generation $(T P G)$ and transverse amplified spontaneous emission (TASE), which can limit the stored energy in the gain medium, and so the energy that can be extracted by the seed pulses. On the other hand, high pulse energies in the Joule regime required for ultrahigh peak intensities with femtosecond pulse durations, will lead to high average power operation even at a low repetition rate of $10 \mathrm{~Hz}$. Since a large amount of the absorbed pump pulse energy is deposited as heat in the gain medium, operating the laser at high average power will put a high demand on the cooling system of the amplifier itself. The special geometry of thin disk lasers, optimized for diode-pumped operation was proved to be extremely efficient in upscaling the average power of $\mathrm{CW}$ and also pulsed output of these arrangements. In this technique a disk of the gain medium with a thickness of around a few hundreds of $\mu \mathrm{m}$ is attached to a heat sink by bonding it to a diamond or other heat spreader. The method was mostly applied for Yb-doped gain media, especially to Yb:YAG crystals. However, the higher room temperature thermal conductivity and the extremely broad emission spectrum of Ti:Sa could potentially promote this material to be used in ultrahigh peak and high average power laser systems in combination with the thin disk geometry.

C3.a. I will investigate the possibilities of the realization of ultrahigh peak power TD Ti:Sa amplifier stages. I will perform simulations on the temperature distribution in conventional and TD amplifier stages.

C3.b. I will investigate the amplification in a water-cooled TD laser head experimentally. I will measure the temperature change and the steady-state temperature profile in the Ti:Sa crystal during pumping. Finally, I will determine the wavefront distortion due to thermal effects in the amplifier crystal induced by the pump pulses.

Since many applications require large number of pulses for a single measurement campaign, it is highly advantageous for pulses to have ultrahigh peak power and a high repetition rate at the same time, which leads to average powers from 100s of $\mathrm{W}$ to $\mathrm{kW}$. This can be only achieved, if the thermal issues connected with the amplification process in laser crystals, especially in Ti:Sa, are well engineered. Numerical simulations can provide a test bed for the investigation of different cooling schemes based on the thin disk geometry. Building a numerical model, that resolves the flow of the coolant and the heat transfer of both the gain medium and the fluid in the coolant channel is necessary to support the design and development of new amplifier head arrangements.

C4.a. I will build a numerical model for a possible TD Ti:Sa final amplifier of the HF-100 system. I will determine the effect of water-cooling on the temperature profile in the gain medium with single- and double-sided cooling arrangements.

C4.b. My final aim was to investigate the upscaling prospects of the double-sided cooling scheme for TD Ti:Sa amplifiers. I plan to determine the thermal conditions of amplifiers with higher output energy at different repetition rates, with single and double disk laser heads.

\section{VI.3. Methods of investigation}

Throughout my research activity I have used different experimental techniques, devices, and software, not to mention the numerical simulation codes. I will summarize these in a few main points: 
M1. I have performed measurements on the CEP drift and noise of water-cooled Ti:Sa amplification by using the method of spectrally resolved interferometry (SRI). I have built an asymmetrically split MachZehnder interferometer with a three-pass amplifier in its sample arm. Stretched and amplified pulses of a CPA system were coupled to the interferometer. As a pump source, a Nd:YLF laser with a long term energy stability of $0.2 \%$ root mean square $(R M S)$ was used. For the detection of the interference fringes I have used a high-resolution imaging spectrograph. The interference fringes were averaged along the spatial axis, which resulted in spectrally resolved fringes. The fringes were evaluated by using the Fourier-transformation method, for which I have compiled a code in MATLAB environment. Based on the spectral phase extracted from the fringes, I have performed polynomial fitting to determine the phase derivates, and the CEP drift. I have conducted measurements on a second amplifier stage pumped with more energetic pulses, in which a Ti:Sa crystal with smaller thickness was investigated. By using the temperature and frequency dependence of the refractive index of the crystal, I have built a simple model to compare the experimentally obtained results on the effect of cooling on the CEP with theory.

M2.a. I have investigated the spectral phase fluctuations of a cryogenically cooled, double-pass Ti:Sa amplifier by using the SRI technique. To decrease the noise of the measurement, I have built the amplifier in the sample arm of a compact Michelson-type interferometer. The Ti:Sa crystal in its copper mount was placed in a compact vacuum chamber, and attached to the cold finger of a cryogenic refrigerator, which was operated with liquid helium, and had a minimal temperature of around $30 \mathrm{~K}$. During the operation of the cryogenic cooler, I have reached a minimal pressure of $10^{-6}$ mbar. I have built and calibrated a high-resolution spectrometer with a line scan camera capable of reaching $70 \mathrm{kHz}$ frame rate for the detection of the interference fringes. For the evaluation, I have used the Fouriertransformation method. I have measured the spectral phase noise during different operation stages of the setup, i.e. operation of the vacuum and cryogenic systems, without pumping the Ti:Sa crystal. To measure the effect of amplification on the spectral phase, I have coupled stretched and amplified pulses from CPA system to the interferometer. For the investigation of the phase noise spectrum of the amplifier, I have performed a high-speed measurement with $10 \mathrm{kHz}$ acquisition rate of the interference fringes, by using pulses from the Ti:Sa oscillator of the CPA system. I have also measured the mechanical vibrations by using an accelerometer attached to the optical table.

M2.b. To determine the CEP drift in the amplifier, I have measured the dependence of the zero and first order spectral phase derivates on the length of the reference arm of the interferometer, and on temperature of the Ti:Sa crystal. I have investigated the effect of amplification on the phase by exciting the Ti:Sa crystal with pump pulses of constant $10 \mathrm{~mJ}$ energy. I have set a gain of ten, to compensate for the asymmetrical split of the interferometer. For pumping the amplifier, I have used the same pump laser, which was utilized in the water-cooled amplifier experiments. By turning off the cryogenic refrigerator, I have also investigated the effect of amplification on the spectral phase noise around the minimal temperature with a decreased measurement noise.

M3.a. I have built a numerical model by using the finite element method (FEM) in the COMSOL Multiphysics software for the investigation of cooling in TD and conventional Ti:Sa final amplifier stages. By using a constant temperature boundary condition at the cooled surfaces, I have obtained stationary temperature results for the two types of amplifiers, with ideal cooling.

M3.b. I have contributed to the experimental demonstration of the first TD Ti:Sa amplifier stage with the extraction during pumping (EDP) method by building the optical setup and performing diagnostics. 
The EDP-TD amplifier was operated by using the seed and pump pulses of the final cryogenically cooled amplifier of a 100 TW peak power laser system. The active mirror geometry consisted of three passes for the seed pulses, and two passes for the pump pulses from three pump lasers with $2 \mathrm{~J}$ pulse energy at a maximal repetition rate of $10 \mathrm{~Hz}$, each. By using a photodiode in front of the Ti:Sa disk, I have measured the scattered fluorescence from the crystal to investigate transversal lasing. By using a thermal camera, I have investigated the temperature changes in the Ti:Sa crystal during pumping. I have used a Shack-Hartmann wavefront sensor to measure the wavefront distortion due to the temperature gradient in the crystal induced by pump pulses. For this, I have used the beam of a $\mathrm{He}-\mathrm{Ne}$ laser, which was reflected from the back side of the Ti:Sa crystal.

M4.a. I have built a two dimensional FEM numerical model, which simulated the cooling of the Ti:Sa crystal in a $100 \mathrm{TW}$ class amplifier module. I have tested single- and double-sided cooling arrangements, where both the coolant water flow and the heat transfer in both the crystal and the coolant were incorporated to the model. The geometry of the laser head was provided the engineers of ELI-ALPS. I have optimized the cooling efficiency by changing with the coolant flow velocity inside the coolant channels.

M4.b. I have performed simulations for amplifier modules with higher peak power by increasing the pump energy, and the Ti:Sa disk size. I have set the diameter of the Ti:Sa crystal and the pump beam in order to obtain the same pump energy fluence in all cases. Moreover, I have also investigated the effect of contra-directional flows, multiple crystals and coolant channels on the temperature distribution in the laser head.

\section{VI.4. New scientific results}

The summary of my scientific results is given in the thesis points of the following:

T1. I have investigated the CEP stability of water-cooled Ti:Sa amplification for different laser parameters. I have found a CEP drift of $11 \mathrm{mrad} /{ }^{\circ} \mathrm{C} / \mathrm{mm}$ for unit temperature change, normalized to the length of the crystal. I have measured a linear increase of the CEP noise with the pump energy, and an exponential like decrease with the repetition rate. Within the sensitivity of the measurement, I have not found any effect of the seed energy on the CEP drift and noise [TP1].

T2.a. I have measured the spectral phase noise of a cryogenically cooled Ti:Sa amplifier in different operational stages of the vacuum- and cooling systems. Spectral phase noise contributions of around $50 \mathrm{mrad}$ RMS for both the vacuum-, and the cryogenic systems have been found, individually [TP2]. Moreover, I have compared the spectral phase noise spectra with the frequency distribution of the mechanical noise measured in the optical setup, and I have identified the main noise sources.

T2.b. I have measured the spectral phase noise of the amplified pulses for different repetition rates. Statistics of the thermally and mechanically originated CEP noise contributions of the amplifier have been determined. I have found CEP noise values less than 12 mrad RMS for the thermal, and less than 1 mrad RMS for the mechanical contributions, respectively [TP2].

T3.a. I have suggested the EDP method to be used in combination with the TD technique for the average power scaling of Ti:Sa final amplifiers. By using numerical simulations, the thermal conditions of $2 \mathrm{PW}$ peak power amplifiers operated with conventional and the EDP-TD methods 
have been compared. I have found, that the EDP-TD technique significantly improved the distribution of temperature in the gain medium [TP3].

T3.b. I have experimentally demonstrated the operation of a 100 TW class Ti:Sa EDP-TD final amplifier. By performing single shot experiments, an amplified pulse energy of $2.6 \mathrm{~J}$ with $5 \mathrm{~J}$ of absorbed pump and $0.5 \mathrm{~J}$ of input seed energy has been reached. I have measured the temperature change in the Ti:Sa crystal in case of pumping with pulses of $4 \mathrm{~J}$ energy at $10 \mathrm{~Hz}$ repetition rate, without amplification of seed pulses. I have found a uniform distribution of temperature with a peak value of $30.3^{\circ} \mathrm{C}$. Finally, I have measured the wavefront distortion due to pump pulses for two passes through the crystal [TP4].

T4.a. I have conducted two dimensional numerical simulations on the cooling efficiency of a possible EDP-TD Ti:Sa final amplifier of the HF-100 laser. I have investigated single- and doublechannel cooling arrangements. I have shown, that by using a $4 \mathrm{~mm}$ thick crystal in case of the double-channel cooling, the temperature difference can be lowered down to $35^{\circ} \mathrm{C}$ [TP5].

T4.b. I have investigated EDP-TD amplifiers with higher peak power at different repetition rates, up to the $8.5 \mathrm{PW}$ level. I have further increased the cooling efficiency by using double crystal arrangements with three coolant channels. This technique holds promise on making amplifiers with multiple $\mathrm{kW}$ average, and multiple PW peak powers feasible [TP5]. 


\section{Köszönetnyilvánítás}

Jelen fejezetben megpróbálom összegyüjteni mindazokat, akik közvetlenül, vagy közvetve hozzájárultak a disszertációm megírásához vezető úthoz. Elsőként szeretnék köszönetet mondani $D r$. Osvay Károlynak, aki a BSc képzéstől kezdve ellátott tanácsaival, útmutatásával, valamint olyan látásmóddal ismertetett meg a kutató pályán, amely nélkülözhetetlen volt munkám során. Szeretném továbbá megköszönni neki, hogy korán bekapcsolódhattam a TeWaTi Kutatócsoport tagjaként a femtoszekundumos lézerekkel kapcsolatos kutatásokba, amely hatalmas mennyiségü tapasztalatot és élményt jelentett számomra. Köszönöm témavezetőmnek, Dr. Börzsönyi Ádámnak, aki a laboratóriumi munkával kapcsolatos alapvető ismereteket, a spektrális interferometriához köthető rengeteg tapasztalatot megosztotta velem. Türelme, oktató kritikái, valamint kedvessége és pozitív hozzáállása szintén nélkülözhetetlenek voltak kutatásaim sikerében.

Szeretném megköszönni a Nagyintenzitású Lézer Csoport tagjai közül Dr. Vladimir Chvykovnak, hogy az ELI-ALPS-nál folytatott munkám során a kezdetektől fogva támogatta kutatói törekvéseimet. Barátságos és pozitív hozzáállása, valamint tapasztalatainak megosztása szintén fontos volt az idáig vezető úton. Köszönöm továbbá Dr. Huabao Caonak, hogy kreativitásával ösztönözte munkámat, amely során bármely alkalommal bizalommal fordulhattam hozzá ötleteimmel, problémáimmal kapcsolatban. Laborbéli munkám során számos hasznos tanáccsal látott el, amelyek a gördülékeny problémamegoldást nagyban elösegítették. Szeretném megköszönni Dr. Mikhail Kalashnikovnak, hogy munkám során rendkívül hasznos kritikáival és ötleteivel hozzájárult a kutatások sikereihez. Köszönöm továbbá, hogy a Max-Born-Institut-ban való kutatói tevékenységem idején rendelkezésre bocsátotta a szükséges kutatási eszközöket, valamint a munkám során tanúsított közvetlenségéért és segítségéért.

Köszönöm Dr. Jójárt Péternek, aki rengeteg hasznos ötletével, technikai megoldásaival és tapasztalataival nagymértékben hozzájárult a munkám sikereihez. Továbbá köszönöm neki, hogy disszertációm alapos lektorálásával jelentősen hozzájárult a dolgozat minőségéhez.

Szeretném megköszönni korábbi évfolyamtársaimnak, immáron jelenlegi kollégáimnak a TeWaTi Kutatócsoportból, illetve az ELI-ALPS-tól, kiemelve Kovács Mátét és Flender Rolandot, akik a TeWaTi lézerrendszerének üzemeltetésén túl baráti segítséget nyújtottak a mindennapok során. Kiemelném továbbá Tóth Szabolcsot, aki meghatározta a munkanapok hangulatát, valamint a nemlineáris optikával és lézerekkel kapcsolatos diszkussziók révén hozzájárult a szakmai fejlődésemhez. Köszönöm Börzsönyi Ferencnek, aki a TeWaTi Laboratóriumban biztosított állandó technikai segítséget és baráti hozzáállást a problémák megoldásában. Köszönöm továbbá Dr. Kovács Attilának hasznos tanácsait a spektrális interferometriával kapcsolatos kérdésekben, valamint Dr. Kiss Bálintnak, hogy jelentősen hozzájárult a pozitív és vidám munkakörnyezet kialakításához.

A kutatói munka mellett keletkezö ügyintézéssel kapcsolatban mindig bátran fordulhattam Verseghy Veronikához, majd Unghváryné Kerekes Arikához a TeWaTi Kutatócsoportnál. Az ELI-ALPS-nál folytatott munkám során pedig kiemelném Zimányiné Horváth Verát, Váradi Zitát és Ékesné Balogh Renátát, akik segítségükkel szintén hozzájárultak a felmerülö gondok kezeléséhez.

Köszönöm az ELI-HU Nonprofit Kft. vezetőinek, hogy lehetővé tették doktori tanulmányaim elvégzését.

Köszönöm családtagjaimnak, hogy támogatásukkal és biztatásukkal hozzájárultak céljaim eléréséhez. 
Nem juthattam volna idáig leendő feleségem, Csongrádi Krisztina odaadó támogatása, türelme és szeretete nélkül, így szeretném megköszönni évtizedes kitartását, amely mindig átsegített a nehézségeken. Ösztönző és biztató hozzáállását nem fogom tudni elégszer meghálálni.

Kutatási eredményeim az Európai Unió támogatásával, a TÁMOP 4.2.2.A-11/1/KONV-2012-0060 azonosító számú, „Impulzuslézerek alkalmazása az anyagtudományban és a biofotonikában” címü projekt forrásai nélkül nem valósulhattak volna meg. Munkám során nélkülözhetetlenek voltak a Laserlab-Europe EC-GA 284464, továbbá a Laserlab-Europe EC-GA 654148, valamint a LaserlabEurope EC-FP7 284464 azonosítószámú források. Munkámat és eredményeim megvalósulását a GINOP-2.3.6-15-2015-00001 azonosítószámú, „ELI lézer kutatóközpont megvalósítása (ELI-ALPS) nagyprojekt, 2. fázis" című forrás biztosította. Továbbá, eredményeim az Európai Unió támogatásával, az Európai Szociális Alap társfinanszírozásával, az EFOP-3.6.2-16-2017-00005, azonosítószámú, „Ultragyors fizikai folyamatok atomokban, molekulákban, nanoszerkezetekben és biológiai rendszerekben" címü forrás segítségével jöttek létre. 


\section{Gyakran használt rövidítések jegyzéke}

\begin{tabular}{|c|c|c|}
\hline Rövidítés & Angol nyelvü kifejezés & $\begin{array}{l}\text { Magyar nyelvü } \\
\text { megfeleltetés }\end{array}$ \\
\hline Ti:Sa & Ti:Sapphire & titán-zafír \\
\hline CEP & carrier-envelope phase & vivő-burkoló fázis \\
\hline$G D$ & group delay & csoportkésleltetés \\
\hline$G D D$ & group delay dispersion & csoportkésleltetés diszperzió \\
\hline TOD & third order dispersion & harmadrendủ diszperzió \\
\hline FOD & fourth order dispersion & negyedrendü diszperzió \\
\hline$Q O D$ & fifth order dispersion & ötödrendű diszperzió \\
\hline RMS & root-mean square & négyzetes középérték \\
\hline$C P A$ & chirped pulse amplification & $\begin{array}{l}\text { fázismodulált } \\
\text { impulzuserősítés }\end{array}$ \\
\hline$A S E$ & amplified spontaneous emission & erősített spontán emisszió \\
\hline OPA & optical parametric amplification & optikai parametrikus erősítés \\
\hline ОРСРА & $\begin{array}{l}\text { optical parametric chirped pulse } \\
\text { amplification }\end{array}$ & $\begin{array}{l}\text { optikai parametrikus } \\
\text { fázismodulált } \\
\text { impulzuserősítés }\end{array}$ \\
\hline DPSS & diode-pumped solid-state & dióda pumpált szilárdtest \\
\hline$D C P A$ & double chirped pulse amplification & $\begin{array}{l}\text { kétfokozatú fázismodulált } \\
\text { impulzuserősítés }\end{array}$ \\
\hline$X P W$ & cross-polarized wave & kereszt-polarizált hullám \\
\hline$W L G$ & wight light generation & fehérfény keltés \\
\hline$T D$ & thin disk & korong geometria \\
\hline$H R$ & high-reflection & magas reflexiójú \\
\hline$A R$ & anti-reflection & alacsony reflexiójú \\
\hline$S H G$ & second harmonic generation & másodharmonikus keltés \\
\hline$D F G$ & difference frequency generation & különbségi frekvencia keltés \\
\hline$S R I$ & spectrally resolved interferometry & $\begin{array}{l}\text { spektrálisan bontott } \\
\text { interferometria }\end{array}$ \\
\hline$M Z I$ & Mach-Zehnder interferometer & $\begin{array}{l}\text { Mach-Zehnder } \\
\text { interferométer }\end{array}$ \\
\hline PSD & power spectral density & $\begin{array}{l}\text { spektrális } \\
\text { teljesítménysürüség }\end{array}$ \\
\hline$T P G$ & transverse parasitic generation & $\begin{array}{l}\text { transzverzális parazita } \\
\text { lézermüködés }\end{array}$ \\
\hline$T A S E$ & $\begin{array}{l}\text { transverse amplified spontaneous } \\
\text { emission }\end{array}$ & $\begin{array}{l}\text { transzverzális erősített } \\
\text { spontán emisszió }\end{array}$ \\
\hline$E D P$ & extraction during pumping & $\begin{array}{l}\text { pumpálás közbeni } \\
\text { energiakicsatolás }\end{array}$ \\
\hline$E D P-T D$ & extraction during pumping - thin disk & $\begin{array}{l}\text { pumpálás közbeni } \\
\text { energiakicsatolás } \\
\text { koronglézer geometriával }\end{array}$ \\
\hline
\end{tabular}


végeselem módszer 


\section{Irodalomjegyzék}

1. T. H. Maiman, "Stimulated Optical Radiation in Ruby," Nature 187, 493-494 (1960).

2. B. P. Abbott et al, "Observation of gravitational waves from a binary black hole merger," Phys. Rev. Lett. 116, 1-16 (2016).

3. F. Krausz and M. Ivanov, "Attosecond physics," Rev. Mod. Phys. 81, 163-234 (2009).

4. K. Yamakawa, M. Aoyama, S. Matsuoka, T. Kase, Y. Akahane, and H. Takuma, "100 TW sub20 fs Ti:sapphire laser system operating at a $10 \mathrm{~Hz}$ repetition rate," Opt. Lett. 23, 1468 (1998).

5. V. Yanovsky, V. Chvykov, G. Kalinchenko, P. Rousseau, T. Planchon, T. Matsuoka, A. Maksimchuk, J. Nees, G. Cheriaux, G. Mourou, and K. Krushelnick, "Ultra-high intensity300-TW laser at $0.1 \mathrm{~Hz}$ repetition rate.," Opt. Express 16, 2109-2114 (2008).

6. M. Aoyama, K. Yamakawa, Y. Akahane, J. Ma, N. Inoue, H. Ueda, and H. Kiriyama, "0.85PW, 33-fs Ti:sapphire laser.," Opt. Lett. 28, 1594-1596 (2003).

7. "CLPU VEGA PW Laser, VEGA-2," https://www.clpu.es/en/facilties-vega-features.

8. K. Nakamura, H. S. Mao, A. J. Gonsalves, H. Vincenti, D. E. Mittelberger, J. Daniels, A. Magana, C. Toth, and W. P. Leemans, "Diagnostics, Control and Performance Parameters for the BELLA High Repetition Rate Petawatt Class Laser," IEEE J. Quantum Electron. 53, 1-22 (2017).

9. "Extreme Light Infrastructure - Nuclear Physics, High Power Laser System," http://www.elinp.ro/research-activities-ra1.php.

10. W. Leemans, Report of Workshop on Laser Technology for K-BELLA and Beyond (2017).

11. "APOLLON Laser," https://portail.polytechnique.edu/luli/en/cilex-apollon/apollon.

12. J. H. Sung, H. W. Lee, J. Y. Yoo, J. W. Yoon, C. W. Lee, J. M. Yang, Y. J. Son, Y. H. Jang, S. K. Lee, and C. H. Nam, "4.2 PW, 20 fs Ti:sapphire laser at 0.1 Hz," Opt. Lett. 42, 2058-2061 (2017).

13. "Extreme Light Infrastructure - Beamlines, HAPLS Laser," https://www.elibeams.eu/en/facility/lasers/13-pw-30-j-10-hz-beamline/.

14. S. Kühn, M. Dumergue, S. Kahaly, S. Modal, M. Füle, T. Csizmadia, B. Farkas, B. Major, Z. Várallyay, F. Calegari, M. Devetta, F. Frassetto, E. Mansson, L. Poletto, S. Stagira, C. Vozzi, M. Nisoli, P. Rudawski, S. Maclot, F. Campi, H. Wikmark, C. L. Arnold, C. M. Heyl, P. Johnsson, A. L'Huillier, R. Lopez-Martenz, S. Haessler, M. Bocoum, F. Boehle, A. Vernier, G. Iaquaniello, E. Skantzakis, N. Papadakis, C. Kalpouzos, P. Tzallas, F. Lépine, D. Charalambidis, K. Varjú, K. Osvay, and G. Sansone, "The ELI-ALPS facility : the next generation of attosecond sources," J. Phys. B At. Mol. Opt. Phys. 50, 132002 (2017).

15. X. Zeng, K. Zhou, Y. Zuo, Q. Zhu, J. Su, X. Wang, X. Wang, X. Huang, X. Jiang, D. Jiang, Y. Guo, N. Xia, S. Zhou, Z. Wu, J. Mu, H. Peng, and F. Jing, "Multi-petawatt laser facility fully based on optical parametric chirped-pulse amplification," Opt. Lett. 42, 2014-2017 (2017).

16. R. Budriūnas, T. Stanislauskas, J. Adamonis, A. Aleknavičius, G. Veitas, D. Gadonas, S. Balickas, A. Michailovas, and A. Varanavičius, "53 W average power CEP-stabilized OPCPA system delivering 55 TW few cycle pulses at $1 \mathrm{kHz}$ repetition rate," Opt. Express 25, 5797 5806 (2017).

17. J. C. Diels and W. Rudolph, Ultrashort Laser Pulse Phenomena, 2nd ed. (Elsevier, 2006).

18. M. Born and E. Wolf, Principles of Optics, 7th ed. (Cambridge University Press, 1999). 
19. C. Rullière, Femtosecond Laser Pulses: Principles and Experiments, 2nd ed. (Springer, 2003).

20. A. Weiner, Ultrafast Optics (John Wiley \& Sons, Inc, 2009).

21. J. D. Jackson, Classical Electrodynamics (John Wiley \& Sons, Inc, 1999).

22. I. Walmsley, L. Waxer, and C. Dorrer, "The role of dispersion in ultrafast optics The role of dispersion in ultrafast optics," Rev. Sci. Instrum. 72, (2001).

23. D. H. Sutter, G. Steinmeyer, L. Gallmann, N. Matuschek, F. Morier-Genoud, U. Keller, V. Scheuer, G. Angelow, and T. Tschudi, "Semiconductor saturable-absorber mirror-assisted Kerr-lens mode-locked Ti:sapphire laser producing pulses in the two- cycle regime," Opt. Lett. 24, 631-633 (1999).

24. G. Steinmeyer, "A review of ultrafast optics and optoelectronics," J. Opt. A Pure Appl. Opt. 5, R1-R15 (2002).

25. G. Steinmeyer, D. Sutter, L. Gallmann, N. Matuschek, and U. Keller, "Frontiers in Ultrashort Pulse Generation: Pushing the Limits in Linear and Nonlinear Optics," Science 286, 15071512 (1999).

26. S. Backus, C. G. Durfee, M. M. Murnane, and H. C. Kapteyn, "High power ultrafast lasers," Rev. Sci. Instrum. 69, 1207-1223 (1998).

27. U. Morgner, F. X. Kärtner, S. H. Cho, Y. Chen, H. a Haus, J. G. Fujimoto, E. P. Ippen, V. Scheuer, G. Angelow, and T. Tschudi, "Sub-two-cycle pulses from a Kerr-lens mode-locked Ti:sapphire laser," Opt. Lett. 24, 411-413 (1999).

28. R. Ell, U. Morgner, F. X. Kärtner, J. G. Fujimoto, E. P. Ippen, V. Scheuer, G. Angelow, T. Tschudi, M. J. Lederer, A. Boiko, and B. Luther-Davies, "Generation of 5-fs pulses and octavespanning spectra directly from a Ti:sapphire laser," Opt. Lett. 26, 373-375 (2001).

29. T. Brabec and F. Krausz, "Intense few-cycle laser fields: Frontiers of nonlinear optics," Rev. Mod. Phys. 72, 545-591 (2000).

30. G. Steinmeyer, B. Borchers, and F. Lücking, "Carrier-Envelope Phase Stabilization," in Progress in Ultrafast Intense Laser Science (Springer Series in Chemical Physics, 2013), pp. 89-110.

31. T. Udem, R. Holzwarth, and T. W. Hänsch, "Optical frequency metrology," Nature 416, 233 237 (2002).

32. S. T. Cundiff and J. Ye, "Colloquium: Femtosecond optical frequency combs," Rev. Mod. Phys. 75, 325-342 (2003).

33. P. A. Franken, A. E. Hill, C. W. Peters, and G. Weinreich, "Generation of optical harmonics," Phys. Rev. Lett. 7, 118-119 (1961).

34. M. Bass, P. a Franken, F. Ward, and G. Weinreich, "Optic Rectification," Phys. Rev. Lett. 9, 446-448 (1962).

35. N. Bloembergen and P. Lallemand, "Complex intensity-dependent index of refraction, frequency broadening of stimulated raman lines, and stimulated rayleigh scattering," Phys. Rev. Lett. 16, 81-84 (1966).

36. R. W. Hellwarth, "Theory of the pulsation of fluorescent light from ruby," Phys. Rev. Lett. 6, 9-12 (1961).

37. R. W. Hellwarth and F. J. McClung, "Giant Pulsations from Ruby," Bull. Am. Phys. Soc. 6, 414 (1961).

38. W. E. Lamb, "Theory of an Optical Maser," Phys. Rev. 134, A1429-A1450 (1964). 
39. L. E. Hargrove, R. L. Fork, and M. A. Pollack, "Locking of HeNe laser modes induced by synchronous intracavity modulation," Appl. Phys. Lett. 5, 4-5 (1964).

40. M. DiDomenico, "Small-signal analysis of internal (coupling-type) modulation of lasers," J. Appl. Phys. 35, 2870-2876 (1964).

41. H. Fattahi, H. G. Barros, M. Gorjan, T. Nubbemeyer, B. Alsaif, C. Y. Teisset, M. Schultze, S. Prinz, M. Haefner, M. Ueffing, A. Alismail, L. Vámos, A. Schwarz, O. Pronin, J. Brons, X. T. Geng, G. Arisholm, M. Ciappina, V. S. Yakovlev, D.-E. Kim, A. M. Azzeer, N. Karpowicz, D. Sutter, Z. Major, T. Metzger, and F. Krausz, "Third-generation femtosecond technology," Optica 1, 45-63 (2014).

42. E. P. Ippen, C. V. Shank, and A. Dienes, "Passive mode locking of the cw dye laser," Appl. Phys. Lett. 21, 348-350 (1972).

43. J. P. Letouzey and S. O. Sari, "Continuous pulse train dye laser using an open flowing passive absorber," Appl. Phys. Lett. 23, 311-313 (1973).

44. C. V. Shank and E. P. Ippen, "Subpicosecond kilowatt pulses from a mode-locked cw dye laser," Appl. Phys. Lett. 24, 373-375 (1974).

45. Z. Bor and A. Müller, "Picosecond Distributed Feedback Dye Lasers," IEEE J. Quantum Electron. 22, 1524-1533 (1986).

46. R. L. Fork, B. I. Greene, and C. V. Shank, "Generation of optical pulses shorter than 0.1 psec by colliding pulse mode locking," Appl. Phys. Lett. 38, 671-672 (1981).

47. W. Dietel, J. J. Fontaine, and J.-C. Diels, "Intracavity pulse compression with glass: a new method of generating pulses shorter than $60 \mathrm{fsec}$," Opt. Lett. 8, 4-6 (1983).

48. W. H. Knox, M. C. Downer, R. L. Fork, and C. V Shank, "Amplified femtosecond optical pulses and continuum generation at 5-kHz repetition rate.," Opt. Lett. 9, 552-554 (1984).

49. P. F. Moulton, "Ti-doped sapphire: tunable solid-state laser," Opt. News 8, 9-9 (1982).

50. P. F. Moulton, "Spectroscopic and Laser Characteristics of Ti: $\mathrm{Al}_{2} \mathrm{O}_{3}$," J. Opt. Soc. Am. B 3, 125-133 (1986).

51. D. E. Spence, P. N. Kean, and W. Sibbett, "60-fsec pulse generation from a self-mode-locked Ti:sapphire laser," Opt. Lett. 16, 42-44 (1991).

52. W. Koechner, Solid-State Laser Engineering (Springer Science + Business Media, Inc., 2006).

53. G. A. Mourou, T. Tajima, and S. V. Bulanov, "Optics in the relativistic regime," Rev. Mod. Phys. 78, 309-371 (2006).

54. D. Strickland and G. Mourou, "Compression of amplified chirped optical pulses," Opt. Commun. 56, 219-221 (1985).

55. E. B. Treacy, "Optical Pulse Compression With Diffraction Gratings," IEEE J. Quantum Electron. 5, 454-458 (1969).

56. M. Pessot, P. Maine, and G. Mourou, "1000 Times Expansion/Compression of Optical Pulses for Chirped Pulse Amplification," Opt. Commun. 62, 419-421 (1987).

57. O. E. Martinez, "Design of High-Power Ultrashort Pulse Amplifiers by Expansion and Recompression," IEEE J. Quantum Electron. 23, 1385-1387 (1987).

58. P. Maine and G. Mourou, "Amplification of 1-nsec pulses in Nd:glass followed by compression to 1 psec," Opt. Lett. 13, 467-469 (1988).

59. P. Maine, D. Strickland, P. Bado, M. Pessot, and G. Mourou, "Generation of Ultrahigh Peak 
Power Pulses by Chirped Pulse Amplification," IEEE J. Quantum Electron. 24, 398-403 (1988).

60. M. Pessot, J. Squier, G. Mourou, and D. J. Harter, "Chirped-pulse amplification of 100-fsec pulses," Opt. Lett. 14, 797-799 (1989).

61. J. V Rudd, G. Korn, S. Kane, J. Squier, G. a Mourou, and P. Bado, "Chirped-pulse amplification of $55-\mathrm{fs}$ pulses at a $1-\mathrm{kHz}$ repetition rate in a $\mathrm{Ti}^{-} \mathrm{Al}_{2} \mathrm{O}_{3}$ regenerative amplifier," Opt. Lett. 18, 2044-2046 (1993).

62. S. Backus, J. Peatross, C. P. Huang, M. M. Murnane, and H. C. Kapteyn, "Ti:sapphire amplifier producing millijoule-level, 21 -fs pulses at $1 \mathrm{kHz}$," Opt. Lett. 20, 2000-2002 (1995).

63. S. Backus, C. G. Durfee III, G. Mourou, H. C. Kapteyn, and M. M. Murnane, "0.2-TW laser system at $1 \mathrm{kHz}, "$ Opt. Lett. 25, 1256-1258 (1997).

64. C. L. Blanc, G. Grillon, J. P. Chambaret, a Migus, and a Antonetti, "Compact and efficient multipass Ti:sapphire system for femtosecond chirped-pulse amplification at the terawatt level.," Opt. Lett. 18, 140-142 (1993).

65. J. P. Chambaret, C. Le Blanc, G. Chériaux, P. Curley, G. Darpentigny, P. Rousseau, G. Hamoniaux, A. Antonetti, and F. Salin, "Generation of 25-TW, 32-fs pulses at $10 \mathrm{~Hz}$," Opt. Lett. 21, 1921-1923 (1996).

66. P. Tournois, "Acousto-optic programmable dispersive filter for adaptive compensation of group delay time dispersion in laser systems," Opt. Commun. 140, 245-249 (1997).

67. H. Burton, C. Debardelaben, W. Amir, and T. A. Planchon, "Temperature dependence of Ti:Sapphire fluorescence spectra for the design of cryogenic cooled Ti:Sapphire CPA laser," Opt. Express 25, 6954-6962 (2017).

68. "GT Advanced Technologies," https://gtat.com/products/ti-sapphire/.

69. J. Tapping and M. L. Reilly, "Index of Refraction of Sapphire between 24 and $1060^{\circ} \mathrm{C}$ for Wavelengths of 633 and 799 nm," J. Opt. Soc. Am. A Opt. Image Sci. 3, 610-616 (1986).

70. M. J. Weber, Handbook of Laser Science and Technology, Volume IV, Optical Materials: Part 2 (CRC Press, 1986).

71. I. H. Malitson and M. J. Dodge, "Refractive Index and Birefringence of Synthetic Sapphire," in Journal of the Optical Society of America (1972), Vol. 62, p. 1405.

72. R. W. Boyd, Nonlinear Optics, 3rd ed. (Academic Press, 2008).

73. J. M. Eggleston, L. G. DeShazer, and K. W. Kangas, "Characteristics and Kinetics of LaserPumped Ti:Sapphire Oscillators.," IEEE J. Quantum Electron. 24, 1009-1015 (1988).

74. T. A. Planchon, F. Burgy, J. P. Rousseau, and J. P. Chambaret, "3D Modeling of amplification processes in CPA laser amplifiers," Appl. Phys. B Lasers Opt. 80, 661-667 (2005).

75. D. C. Brown, "The promise of cryogenic solid-state lasers," IEEE J. Sel. Top. Quantum Electron. 11, 587-599 (2005).

76. M. G. Holland, "Thermal conductivity of several optical maser materials," J. Appl. Phys. 33, 2910-2911 (1962).

77. R. L. Aggarwal, A. Sanchez, M. M. Stuppi, R. E. Fahey, A. J. Strauss, W. R. Rapoport, and C. P. Khattak, "Residual Infrared Absorption in As-Grown and Annealed Crystals of $\mathrm{Ti}_{2} \mathrm{Al}_{2} \mathrm{O}_{3}$," IEEE J. Quantum Electron. 24, 1003-1008 (1988).

78. N. G. Basov, R. V Ambartsumyan, V. S. Zuev, P. G. Kryukov, and V. S. Letokhov, "Nonlinear amplification of light pulses," Sov. Phys. JETP 23, 16-22 (1966). 
79. G. L. Lamb, "Analytical descriptions of ultrashort optical pulse propagation in a resonant medium," Rev. Mod. Phys. 43, 99-124 (1971).

80. L. M. Frantz and J. S. Nodvik, "Theory of pulse propagation in a laser amplifier," J. Appl. Phys. 34, 2346-2349 (1963).

81. C. E. Byvik and A. M. Buoncristiani, "Analysis of Vibronic Transitions in Titanium Doped Sapphire Using the Temperature of the Fluorescence Spectra," IEEE J. Quantum Electron. 21, 1619-1624 (1985).

82. C. Le Blanc, P. Curley, and F. Salin, "Gain-narrowing and gain-shifting of ultra-short pulses in Ti: sapphire amplifiers," Opt. Commun. 131, 391-398 (1996).

83. R. R. Thomson, D. T. Reid, and C. T. Leburn, Ultrafast Nonlinear Optics (Springer, 2013).

84. H. Fattahi, Third-Generation Femtosecond Technology (Springer Theses, 2014).

85. S. Guha and L. P. Gonzalez, Laser Beam Propagation in Nonlinear Optical Media (CRC Press, 2014).

86. G. Cerullo and S. De Silvestri, "Ultrafast optical parametric amplifiers," Rev. Sci. Instrum. 74, $1-18$ (2003).

87. G. Cirmi, C. Manzoni, D. Brida, S. De Silvestri, and G. Cerullo, "Carrier-envelope phase stable, few-optical-cycle pulses tunable from visible to near IR," J. Opt. Soc. Am. B 25, B62B69 (2008).

88. G. Cerullo, A. Baltuška, O. D. Mücke, and C. Vozzi, "Few-optical-cycle light pulses with passive carrier-envelope phase stabilization," Laser Photonics Rev. 5, 323-351 (2011).

89. A. Harth, M. Schultze, T. Lang, T. Binhammer, S. Rausch, and U. Morgner, "Two-color pumped OPCPA system emitting spectra spanning 15 octaves from VIS to NIR," Opt. Express 20, 3076-3081 (2012).

90. M. Baudisch, B. Wolter, M. Pullen, M. Hemmer, and J. Biegert, "High power multi-color OPCPA source with simultaneous femtosecond deep-UV to mid-IR outputs," Opt. Lett. 41, 3583-3586 (2016).

91. L. von Grafenstein, M. Bock, D. Ueberschaer, K. Zawilski, P. Schunemann, U. Griebner, and T. Elsaesser, " $5 \mu \mathrm{m}$ few-cycle pulses with multi-gigawatt peak power at a $1 \mathrm{kHz}$ repetition rate," Opt. Lett. 42, 3796-3799 (2017).

92. U. Elu, M. Baudisch, H. Pires, F. Tani, M. H. Frosz, F. Köttig, A. Ermolov, P. St.J. Russell, and J. Biegert, "High average power and single-cycle pulses from a mid-IR optical parametric chirped pulse amplifier," Optica 4, 1024-1029 (2017).

93. N. Thiré, R. Maksimenka, B. Kiss, C. Ferchaud, P. Bizouard, E. Cormier, K. Osvay, and N. Forget, "4-W, 100-kHz, few-cycle mid-infrared source with sub-100-mrad carrier-envelope phase noise," Opt. Express 25, 1505-1514 (2017).

94. M. Kalashnikov, K. Osvay, and W. Sandner, "High-power Ti:Sapphire lasers: Temporal contrast and spectral narrowing," Laser Part. Beams 25, 219-223 (2007).

95. N. Khodakovskiy, M. Kalashnikov, E. Gontier, F. Falcoz, and P.-M. Paul, "Degradation of picosecond temporal contrast of Ti:sapphire lasers with coherent pedestals," Opt. Lett. 41, 4441-4444 (2016).

96. A. Jullien, S. Kourtev, O. Albert, G. Chériaux, J. Etchepare, N. Minkovski, and S. M. Saltiel, "Highly efficient temporal cleaner for femtosecond pulses based on cross-polarized wave generation in a dual crystal scheme," Appl. Phys. B Lasers Opt. 84, 409-414 (2006). 
97. A. Jullien, L. Canova, O. Albert, D. Boschetto, L. Antonucci, Y. H. Cha, J. P. Rousseau, P. Chaudet, G. Chériaux, J. Etchepare, S. Kourtev, N. Minkovski, and S. M. Saltiel, "Spectral broadening and pulse duration reduction during cross-polarized wave generation: Influence of the quadratic spectral phase," Appl. Phys. B Lasers Opt. 87, 595-601 (2007).

98. L. Canova, O. Albert, N. Forget, B. Mercier, S. Kourtev, N. Minkovski, S. M. Saltiel, and R. Lopez Martens, "Influence of spectral phase on cross-polarized wave generation with short femtosecond pulses," Appl. Phys. B Lasers Opt. 93, 443-453 (2008).

99. L. P. Ramirez, D. N. Papadopoulos, A. Pellegrina, P. Georges, F. Druon, P. Monot, A. Ricci, A. Jullien, X. Chen, J. P. Rousseau, and R. Lopez-Martens, "Efficient cross polarized wave generation for compact, energy-scalable, ultrashort laser sources," Opt. Express 19, 93-98 (2011).

100. "Extreme Light Infrastructure," https://eli-laser.eu/.

101. "Fastlite," http://www.fastlite.com/en/.

102. K. Yamakawa and C. P. J. Barty, "Two-color chirped-pulse amplification in an ultrabroadband Ti:sapphire ring regenerative amplifier," Opt. Lett. 28, 2402-2404 (2003).

103. F. Giambruno, C. Radier, G. Rey, and G. Chériaux, "Design of a 10 PW (150 J/15 fs) peak power laser system with Ti:sapphire medium through spectral control," Appl. Opt. 50, 26172621 (2011).

104. M. Kalashnikov, H. Cao, K. Osvay, and V. Chvykov, "Polarization-encoded chirped pulse amplification in Ti:sapphire: a way toward few-cycle petawatt lasers," Opt. Lett. 41, 25-28 (2016).

105. M. Nisoli, S. De Silvestri, O. Svelto, R. Szipöcs, K. Ferencz, C. Spielmann, S. Sartania, and F. Krausz, "Compression of high-energy laser pulses below 5 fs," Opt. Lett. 22, 522-524 (1997).

106. X. Chen, A. Jullien, A. Malvache, L. Canova, A. Borot, A. Trisorio, C. G. Durfee, and R. Lopez-Martens, "Generation of $4.3 \mathrm{fs}, 1 \mathrm{~mJ}$ laser pulses via compression of circularly polarized pulses in a gas-filled hollow-core fiber.," Opt. Lett. 34, 1588-1590 (2009).

107. J. Travers, W. Chang, J. Nold, N. Joly, and P. Russell, "Ultrafast nonlinear optics in gas-filled hollow-core photonic crystal fibers [Invited]," J. Opt. Soc. Am. B 28, A11-A26 (2011).

108. C.-H. Lu, Y.-J. Tsou, H.-Y. Chen, B.-H. Chen, Y.-C. Cheng, S.-D. Yang, M.-C. Chen, C.-C. Hsu, and A. H. Kung, "Generation of intense supercontinuum in condensed media," Optica 1, 400-406 (2014).

109. P. Lassonde, S. Mironov, S. Fourmaux, S. Payeur, E. Khazanov, A. Sergeev, J.-C. Kieffer, and G. Mourou, "High energy femtosecond pulse compression," Laser Phys. Lett. 13, 75401 (2016).

110. P. He, Y. Liu, K. Zhao, H. Teng, X. He, P. Huang, H. Huang, S. Zhong, Y. Jiang, S. Fang, X. Hou, and Z. Wei, "High-efficiency supercontinuum generation in solid thin plates at $01 \mathrm{TW}$ level," Opt. Lett. 42, 474-477 (2017).

111. P. Russbueldt, T. Mans, G. Rotarius, J. Weitenberg, H. D. Hoffmann, and R. Poprawe, "400W Yb:YAG Innoslab fs-amplifier," Opt. Express 17, 12230-12245 (2009).

112. P. Russbueldt, D. Hoffmann, M. Höfer, J. Löhring, J. Luttmann, A. Meissner, J. Weitenberg, M. Traub, T. Sartorius, D. Esser, R. Wester, P. Loosen, and R. Poprawe, "Innoslab Amplifiers," IEEE J. Sel. Top. Quantum Electron. 21, 3100117 (2015).

113. T. Eidam, S. Hanf, E. Seise, T. V Andersen, T. Gabler, C. Wirth, T. Schreiber, J. Limpert, and A. Tünnermann, "Femtosecond fiber CPA system emitting $830 \mathrm{~W}$ average output power," Opt. Lett. 35, 94-96 (2010). 
114. S. Hädrich, M. Kienel, M. Müller, A. Klenke, J. Rothhardt, R. Klas, T. Gottschall, T. Eidam, A. Drozdy, P. Jójárt, V. Zoltán, E. Cormier, K. Osvay, A. Tünnermann, and J. Limpert, "Energetic sub-2-cycle laser with $216 \mathrm{~W}$ average power," Opt. Lett. 41, 4332-4335 (2016).

115. A. Giesen, H. Hügel, A. Voss, K. Wittig, U. Brauch, and H. Opower, "Scalable concept for diode-pumped high-power solid-state lasers," Appl. Phys. B Lasers Opt. 58, 365-372 (1994).

116. A. Giesen and J. Speiser, "Fifteen years of work on thin-disk lasers: Results and scaling laws," IEEE J. Sel. Top. Quantum Electron. 13, 598-609 (2007).

117. M. C. Gupta and J. Ballato, Handbook of Photonics (CRC Press, 1997).

118. K. Schuhmann, T. W. Hänsch, K. Kirch, A. Knecht, F. Kottmann, F. Nez, R. Pohl, D. Taqqu, and A. Antognini, "Thin-disk laser pump schemes for large number of passes and moderate pump source quality," Appl. Opt. 54, 9400-9408 (2015).

119. O. Pronin, J. Brons, C. Grasse, V. Pervak, G. Boehm, M.-C. Amann, V. L. Kalashnikov, A. Apolonski, and F. Krausz, "High-power 200 fs Kerr-lens mode-locked Yb:YAG thin-disk oscillator," Opt. Lett. 36, 4746-4748 (2011).

120. J. Brons, V. Pervak, D. Bauer, D. Sutter, O. Pronin, and F. Krausz, "Powerful 100-fs-scale Kerr-lens mode-locked thin-disk oscillator," Opt. Lett. 41, 3567-3570 (2016).

121. C. Hönninger, I. Johannsen, M. Moser, G. Zhang, A. Giesen, and U. Keller, "Diode-pumped thin-disk Yb: YAG regenerative amplifier," Appl. Phys. B Lasers Opt. 426, 423-426 (1997).

122. R. Jung, J. Tümmler, and I. Will, "Regenerative thin-disk amplifier for $300 \mathrm{~mJ}$ pulse energy," Opt. Express 24, 883-887 (2016).

123. T. Nubbemeyer, M. Kaumanns, M. Ueffing, M. Gorjan, A. Alismail, H. Fattahi, J. Brons, O. Pronin, H. G. Barros, Z. Major, T. Metzger, D. Sutter, and F. Krausz, "1 kW, 200 mJ picosecond thin-disk laser system," Opt. Lett. 42, 1381-1384 (2017).

124. M. Schulz, R. Riedel, A. Willner, S. Düsterer, M. J. Prandolini, J. Feldhaus, B. Faatz, J. Rossbach, M. Drescher, and F. Tavella, "Pulsed operation of a high average power Yb:YAG thin-disk multipass amplifier.," Opt. Express 20, 5038-5043 (2012).

125. J.-P. Negel, A. Voss, M. Abdou Ahmed, D. Bauer, D. Sutter, A. Killi, T. Graf, and M. A. Ahmed, "1.1 kW average output power from a thin-disk multipass amplifier for ultrashort laser pulses," Opt. Lett. 38, 5442-5445 (2013).

126. J.-P. Negel, A. Loescher, B. Dannecker, P. Oldorf, S. Reichel, R. Peters, M. Abdou Ahmed, and T. Graf, "Thin-disk multipass amplifier for fs pulses delivering $400 \mathrm{~W}$ of average and 2.0 $\mathrm{GW}$ of peak power for linear polarization as well as $235 \mathrm{~W}$ and $1.2 \mathrm{GW}$ for radial polarization," Appl. Phys. B 123, 1-8 (2017).

127. J. Novák, J. T. Green, T. Metzger, T. Mazanec, B. Himmel, M. Horáček, Z. Hubka, R. Boge, R. Antipenkov, F. Batysta, J. A. Naylon, P. Bakule, and B. Rus, "Thin disk amplifier-based 40 mJ, $1 \mathrm{kHz}$, picosecond laser at 515 nm," Opt. Express 24, 5728-5733 (2016).

128. B. Borchers, A. Anderson, and G. Steinmeyer, "On the role of shot noise in carrier-envelope phase stabilization," Laser Photonics Rev. 8, 303-315 (2014).

129. L. Xu, C. Spielmann, A. Poppe, T. Brabec, F. Krausz, and T. W. Hänsch, "Route to phase control of ultrashort light pulses," Opt. Lett. 21, 2008-2010 (1996).

130. H. R. Telle et al., "Carrier-envelope offset phase control: A novel concept for absolute optical frequency measurement and ultrashort pulse generation," Appl. Phys. B 69, 327-332 (1999).

131. David J. Jones, Scott Diddams, Jinendra K. Ranka, Andrew Stentz, Robert S. Windeler, John L. Hall, and Steven T. Cundiff, "Carrier-envelope phase control of femtosecond mode-locked 
lasers and direct optical frequency synthesis," Science (80-. ). 288, 635-640 (2000).

132. F. W. Helbing, G. Steinmeyer, and U. Keller, "Carrier-Envelope Offset Phase-Locking with Attosecond Timing Jitter," IEEE J. Sel. Top. Quantum Electron. 9, 1030-1040 (2003).

133. T. Fuji, J. Rauschenberger, C. Gohle, A. Apolonski, T. Udem, V. S. Yakovlev, G. Tempea, T. W. Hänsch, and F. Krausz, "Attosecond control of optical waveforms," New J. Phys. 7, 1-9 (2005).

134. T. Fuji, A. Apolonski, and F. Krausz, "Self-stabilization of carrier-envelope offset phase by use of difference-frequency generation," Opt. Lett. 29, 632-634 (2004).

135. R. Budriūnas, T. Stanislauskas, and A. Varanavičius, "Passively CEP-stabilized frontend for few cycle terawatt OPCPA system," J. Opt. 17, 94008 (2015).

136. J. Vogelsang, J. Robin, B. Piglosiewicz, C. Manzoni, P. Farinello, S. Melzer, P. Feru, G. Cerullo, C. Lienau, and P. Groß, "High passive CEP stability from a few-cycle, tunable NOPADFG system for observation of CEP-effects in photoemission," Opt. Express 22, 25295 (2014).

137. B. E. Schmidt, A. D. Shiner, P. Lassonde, J.-C. Kieffer, P. B. Corkum, D. M. Villeneuve, and F. Légaré, "CEP stable 1.6 cycle laser pulses at $1.8 \mu \mathrm{m}$," Opt. Express 19, 6858-6864 (2011).

138. M. Kakehata, H. Takada, Y. Kobayashi, K. Torizuka, Y. Fujihira, T. Homma, and H. Takahashi, "Single-shot measurement of carrier-envelope phase changes by spectral interferometry," Opt. Lett. 26, 1436-1438 (2001).

139. S. Koke, C. Grebing, B. Manschwetus, and G. Steinmeyer, "Fast f-to-2f interferometer for a direct measurement of the carrier-envelope phase drift of ultrashort amplified laser pulses," Opt. Lett. 33, 2545-2547 (2008).

140. A. Borzsonyi, A. Kovacs, and K. Osvay, "What We Can Learn about Ultrashort Pulses by Linear Optical Methods," Appl. Sci. 3, 515-544 (2013).

141. W. H. Knox, "Dispersion measurements for femtosecond-pulse generation and applications," Appl. Phys. B Laser Opt. 58, 225-235 (1994).

142. A. P. Kovács, K. Osvay, Z. Bor, and R. Szipöcs, "Group-delay measurement on laser mirrors by spectrally resolved white-light interferometry.," Opt. Lett. 20, 788-790 (1995).

143. K. Misawa and T. Kobayashi, "Femtosecond Sagnac interferometer for phase spectroscopy.," Opt. Lett. 20, 1550-1552 (1995).

144. D. Meshulach, D. Yelin, and Y. Silberberg, "Real-time spatial-spectral interference measurements of ultrashort optical pulses," J. Opt. Soc. Am. B 14, 2095-2098 (1997).

145. C. Dorrer, "Influence of the calibration of the detector on spectral interferometry," J. Opt. Soc. Am. B 16, 1160-1168 (1999).

146. C. Dorrer, N. Belabas, J.-P. Likforman, and M. Joffre, "Spectral resolution and sampling issues in Fourier-transform spectral interferometry," J. Opt. Soc. Am. B 17, 1795-1802 (2000).

147. C. Dorrer and M. Joffre, "Characterization of the spectral phase of ultrashort light pulses," Comptes rendus l'Académie des Sci. Série IV, Phys. Astrophys. 2, 1415-1426 (2001).

148. K. Osvay, M. Görbe, C. Grebing, and G. Steinmeyer, "Bandwidth-independent linear method for detection of the carrier-envelope offset phase.," Opt. Lett. 32, 3095-3097 (2007).

149. P. Jójárt, Á. Börzsönyi, B. Borchers, G. Steinmeyer, and K. Osvay, "Agile linear interferometric method for carrier-envelope phase drift measurement," Opt. Lett. 37, 836-838 (2012).

150. P. Jojart, A. Boerzsoenyi, V. Soskov, F. Zomer, R. Chiche, E. Cormier, and K. Osvay, 
"Carrier-envelope phase drift measurement of picosecond pulses by an all-linear-optical means," Opt. Lett. 39, 5913-5916 (2014).

151. G. G. Paulus, F. Lindner, H. Walther, A. Baltuška, E. Goulielmakis, M. Lezius, and F. Krausz, "Measurement of the Phase of Few-Cycle Laser Pulses," Phys. Rev. Lett. 91, 253004 (2003).

152. T. Wittmann, B. Horvath, W. Helml, M. G. Schätzel, X. Gu, A. L. Cavalieri, G. G. Paulus, and R. Kienberger, "Single-shot carrier-envelope phase measurement of few-cycle laser pulses," Nat. Phys. 5, 357-362 (2009).

153. A. M. Sayler, T. Rathje, W. Müller, C. Kürbis, K. Rühle, G. Stibenz, and G. G. Paulus, "Realtime pulse length measurement of few-cycle laser pulses using above-threshold ionization.," Opt. Express 19, 4464-4471 (2011).

154. A. M. Sayler, M. Arbeiter, S. Fasold, D. Adolph, M. Möller, D. Hoff, T. Rathje, B. Fetić, D. B Milošević, T. Fennel, and G. G. Paulus, "Accurate determination of absolute carrier-envelope phase dependence using photo-ionization.," Opt. Lett. 40, 3137-3140 (2015).

155. D. J. Jones, S. T. Cundiff, T. M. Fortier, J. L. Hall, and J. Ye, "Carrier Envelope Phase Stabilization of Single and Multiple Femtosecond Lasers," Few-Cycle Laser Pulse Gener. Its Appl. 340, 317-343 (2004).

156. S. Koke, C. Grebing, H. Frei, A. Anderson, A. Assion, and G. Steinmeyer, "Direct frequency comb synthesis with arbitrary offset and shot-noise-limited phase noise," Nat. Photonics 4, 462-465 (2010).

157. B. Borchers, S. Koke, A. Husakou, J. Herrmann, and G. Steinmeyer, "Carrier-envelope phase stabilization with sub-10 as residual timing jitter.," Opt. Lett. 36, 4146-4148 (2011).

158. N. Raabe and G. Steinmeyer, "Limits of carrier-envelope phase stabilization," in High Intensity Lasers and High Field Phenomena (2016), p. HS3B.1.

159. F. Lücking, V. Crozatier, N. Forget, A. Assion, and F. Krausz, "Approaching the limits of carrier-envelope phase stability in a millijoule-class amplifier.," Opt. Lett. 39, 3884-3887 (2014).

160. C. Danson, D. Hillier, N. Hopps, and D. Neely, "Petawatt class lasers worldwide," High Power Laser Sci. Eng. 3, 1-14 (2015).

161. T. Oksenhendler, D. Kaplan, P. Tournois, G. M. Greetham, and F. Estable, "Ultrawideband regenerative amplifiers via intracavity acousto-optic programmable gain control," Springer Ser. Opt. Sci. 132, 421-426 (2007).

162. A. Trisorio, P. M. Paul, F. Ple, C. Ruchert, C. Vicario, and C. P. Hauri, "Ultrabroadband TWclass Ti:sapphire laser system with adjustable central wavelength, bandwidth and multi-color operation," Opt. Express 19, 20128-20140 (2011).

163. F. Giambruno, A. Freneaux, and G. Chériaux, "Spectral mirror for ultra-short, high peak power, multi-PW Ti:sapphire lasers," Appl. Phys. B Lasers Opt. 111, 161-164 (2013).

164. S. Zheng, W. Chen, Y. Cai, X. Lu, G. Zheng, J. Li, and S. Xu, "Intra-cavity spectral shaping based on optical rotatory dispersion in a broadband Ti : S regenerative amplifier," Laser Phys. Lett. 12, 85301 (2015).

165. I. Thomann, E. Gagnon, R. Jones, A. Sandhu, A. Lytle, R. Anderson, J. Ye, M. Murnane, and H. Kapteyn, "Investigation of a grating-based stretcher/compressor for carrier-envelope phase stabilized fs pulses.," Opt. Express 12, 3493-3499 (2004).

166. a Renault, D. Z. Kandula, S. Witte, a L. Wolf, R. T. Zinkstok, W. Hogervorst, and K. S. E. Eikema, "Phase stability of terawatt-class ultrabroadband parametric amplification.," Opt. Lett. 32, 2363-2365 (2007). 
167. G. M. Rossi, L. Wang, R. E. Mainz, H. Çankaya, F. X. Kärtner, and G. Cirmi, "CEP dependence of signal and idler upon pump-seed synchronization in optical parametric amplifiers," Opt. Lett. 43, 178-181 (2018).

168. R. S. Nagymihály, "Erősített lézernyalábok koherens összeadása," Szegedi Tudományegyetem (2012).

169. R. S. Nagymihály, "Ultrarövid lézerimpulzusok vivő-burkoló fázisának változásai multipasszos titán-zafír erősítőben," Szegedi Tudományegyetem (2014).

170. Á. Börzsönyi, Z. Heiner, A. P. Kovács, M. P. Kalashnikov, and K. Osvay, "Measurement of pressure dependent nonlinear refractive index of inert gases," Opt. Express 18, 25847-25854 (2010).

171. P. Ferrara, M. Ciofini, L. Esposito, J. Hostaša, L. Labate, A. Lapucci, A. Pirri, G. Toci, M. Vannini, and L. A. Gizzi, "3-D numerical simulation of Yb : YAG active slabs with longitudinal doping gradient for thermal load effects assessment," 22, 23344-23349 (2014).

172. K. F. Wall, R. L. Aggarwal, M. D. Sciacca, H. J. Zeiger, R. E. Fahey, and a J. Strauss, "Optically induced nonresonant changes in the refractive index of Ti: $\mathrm{Al}_{2} \mathrm{O}_{3}$," Opt. Lett. 14, 180-182 (1989).

173. "National Instruments," www.ni.com.

174. D. C. Brown, S. D. Jacobs, and N. Nee, "Parasitic oscillations, absorption, stored energy density and heat density in active-mirror and disk amplifiers," Appl. Opt. 17, 211-224 (1978).

175. F. G. Patterson, J. Bonlie, D. Price, and B. White, "Suppression of parasitic lasing in largeaperture Ti:sapphire laser amplifiers," Opt. Lett. 24, 963-965 (1999).

176. K. Ertel, C. Hooker, S. J. Hawkes, B. T. Parry, and J. L. Collier, "ASE suppression in a high energy Titanium sapphire amplifier," Opt. Express 16, 8039-8049 (2008).

177. V. Chvykov, J. Nees, and K. Krushelnick, "Transverse amplified spontaneous emission: The limiting factor for output energy of ultra-high power lasers," Opt. Commun. 312, 216-221 (2014).

178. F. Ple, M. Pittman, G. Jamelot, and J.-P. Chambaret, "Design and demonstration of a highenergy booster amplifier for a high-repetition rate petawatt class laser system," Opt. Lett. 32, 238-240 (2007).

179. J. H. Sung, S. K. Lee, T. J. Yu, T. M. Jeong, and J. Lee, "0.1 Hz 1.0 PW Ti:sapphire laser," Opt. Lett. 35, 3021-3023 (2010).

180. H. Eilers, U. Hommerich, and W. M. Yen, "Temperature-dependent beam-deflection spectroscopy of Ti3+-doped sapphire," 10, 584-586 (1993).

181. M. Zavelani-Rossi, F. Lindner, C. Le Blanc, G. Chériaux, and J. P. Chambaret, "Control of thermal effects for high-intensity Ti:sapphire laser chains," Appl. Phys. B 70, S193-S196 (2000).

182. V. Chvykov and K. Krushelnick, "Large aperture multi-pass amplifiers for high peak power lasers," Opt. Commun. 285, 2134-2136 (2012).

183. Y. Chu, Z. Gan, X. Liang, L. Yu, X. Lu, C. Wang, X. Wang, L. Xu, H. Lu, D. Yin, Y. Leng, R. $\mathrm{Li}$, and $\mathrm{Z}$. Xu, "High-energy large-aperture Ti:sapphire amplifier for $5 \mathrm{PW}$ laser pulses," Opt. Lett. 40, 5011-5014 (2015).

184. "Comsol Multiphysics," www.comsol.com.

185. "COMSOL Material Library," https://www.comsol.com/material-library. 
186. E. R. Dobrovinskaya, L. A. Lytvynov, and V. Pishchik, Sapphire (Springer Science + Business Media, Inc., 2009).

187. D. G. Archer, "Thermodynamic Properties of Synthetic Sapphire (alfa- $\mathrm{Al}_{2} \mathrm{O}_{3}$ ), Standard Reference Material 720 and the Effect of Temperature-Scale Differences on Thermodynamic Properties," J. Phys. Chem. Ref. Data 22, 1441-1453 (1993).

188. "Max-Born-Institut für Nichtlineare Optik und Kurzzeizspektroskopie im Forschungsverbund Berlin e.V.," www.mbi-berlin.de.

189. M. P. Kalashnikov, L. Ehrentraut, G. Priebe, M. Schnuerer, H. Schoennagel, S. Steinke, and W. Sandner, "Dual-Beam Ultra High Temporal Contrast Ti:Sa Laser System Based on a Double CPA Technique," in Conference on Lasers and Electro-Optics Europe (CLEO EUROPE/IQEC) (2013).

190. "Amplitude Technologies," www.amplitude-technologies.com.

191. A. Jullien, J.-P. Rousseau, B. Mercier, L. Antonucci, O. Albert, G. Chériaux, S. Kourtev, N. Minkovski, and S. M. Saltiel, "Highly efficient nonlinear filter for femtosecond pulse contrast enhancement and pulse shortening," Opt. Lett. 33, 2353-2355 (2008).

192. "Micro-Epsilon," www.micro-epsilon.com.

193. F. R. Menter, "Two-equation eddy-viscosity turbulence models for engineering applications," AIAA J. 32, 1598-1605 (1994).

194. F. Menter, M. Kuntz, and R. Langtry, "Ten years of industrial experience with the SST turbulence model," Turbul. Heat Mass Transf. 4, 625-632 (2003).

195. "The Menter Shear Stress Transport Turbulence Model," https://turbmodels.larc.nasa.gov/sst.html.

196. D. C. Wilcox, Turbulence Modeling for CFD (DCW Industries Inc., 1994).

197. T. L. Bergman, A. S. Lavine, F. P. Incropera, and D. P. DeWitt, Fundamentals of Heat and Mass Transfer, 7th ed. (John Wiley \& Sons, Inc, 2011).

198. Z. Ye, C. Liu, B. Tu, K. Wang, Q. Gao, and C. Tang, "Kilowatt-level direct-"refractive index matching liquid"-cooled Nd :YLF thin disk laser resonator," 24, 1758-1772 (2016).

199. S. Banerjee, K. Ertel, P. D. Mason, P. J. Phillips, M. De Vido, J. M. Smith, T. J. Butcher, C. Hernandez-Gomez, R. J. S. Greenhalgh, and J. L. Collier, "DiPOLE: a 10 J, 10 Hz cryogenic gas cooled multi-slab nanosecond Yb:YAG laser," Opt. Express 23, 19542-19551 (2015).

200. P. Mason, M. Divoký, K. Ertel, J. Pilař, T. Butcher, M. Hanuš, S. Banerjee, J. Phillips, J. Smith, M. De Vido, A. Lucianetti, C. Hernandez-Gomez, C. Edwards, T. Mocek, and J. Collier, "Kilowatt average power $100 \mathrm{~J}$-level diode pumped solid state laser," Optica 4, 438439 (2017).

201. E. N. L. R. Byron Bird, Warren E. Stewart, Transport Phenomena, 2nd ed. (John Wiley \& Sons, Inc, 2002).

202. G. A. Maugin, The Thermomechanics of Nonlinear Irreversible Behaviors: An Introduction (World Scientific, 1999). 


\section{Saját publikációk}

\section{X.1. Tézispontok alapjául szolgáló referált folyóiratcikkek}

TP1. A. Borzsonyi, R. S. Nagymihaly, K. Osvay, "Drift and noise of the carrier-envelope phase in a Ti:Sapphire amplifier," Laser Physics Letters 13, 015301 (2016).

DOI: https://doi.org/10.1088/1612-2011/13/1/015301

TP2. R. S. Nagymihaly, P. Jojart, A. Borzsonyi, K. Osvay, "Spectral Phase Noise Analysis of a Cryogenically Cooled Ti:Sapphire Amplifier," Optics Express 25, 6690-6699 (2017).

DOI: https://doi.org/10.1364/OE.25.006690

TP3. V. Chvykov, R. S. Nagymihaly, H. Cao, M. Kalashnikov, K. Osvay, "Design of a thin disk amplifier with extraction during pumping for high peak and average power Ti:Sa systems (EDPTD)," Optics Express 24, 3721-3733 (2016).

DOI: https://doi.org/10.1364/OE.24.003721

TP4. V. Chvykov, H. Cao, R. Nagymihaly, M. P. Kalashnikov, N. Khodakovskiy, R. Glassock, L. Ehrentraut, M. Schnuerer, and K. Osvay, "High peak and average power Ti:sapphire thin disk amplifier with extraction during pumping," Optics Letters 41, 3017-3020 (2016).

DOI: https://doi.org/10.1364/OL.41.003017

TP5. R. S. Nagymihaly, H. Cao, D. Papp, G. Hajas, M. Kalashnikov, K. Osvay, and V. Chvykov, "Liquid-cooled Ti:Sapphire Thin Disk amplifiers for high average power 100 TW systems," Optics Express 25, 6664-6677 (2017).

DOI: https://doi.org/10.1364/OE.25.006664

\section{X.2. További referált folyóiratcikkek}

P1. H. Cao, M. Kalashnikov, K. Osvay, N. Khodakovskiy, R. S. Nagymihaly, and V. Chvykov, "Active spectral shaping with polarization encoded Ti:Sapphire amplifiers for sub 20-fs multiTW systems," Laser Physics Letters, megjelenés alatt (2018).

P2. R. S. Nagymihaly, H. Cao, P. Jojart, M. Kalashnikov, A. Borzsonyi, V. Chvykov, R. Flender, M. Kovacs, and K. Osvay, "Carrier-envelope phase stability of a polarization-encoded chirped pulse Ti:Sapphire amplifier," Journal of the Optical Society of America B, megjelenés alatt (2018).

\section{X.3. Nemzetközi konferencia prezentációk}

$\mathbf{K E}$ - szóbeli elöadás, $\mathbf{K P}$ - poszter, * - elöadó

KE.1. R. Nagymihaly, P. Jojart, A. Borzsonyi*, and K. Osvay, "Increase of Carrier-Envelope Phase Noise in Water and Cryogenically Cooled Ti:Sapphire Amplifiers," in High-Brightness Sources and Light-Driven Interactions, 20-22 March 2016, Long Beach, California, USA, paper HS3B.4.

URL: https://doi.org/10.1364/HILAS.2016.HS3B.4

KE.2. M. P. Kalashnikov*, H. Cao, K. Osvay, V. Chvykov, N. Khodakovskiy, and R. Nagymihaly, "Polarization Encoded Chirped Pulse Amplification in Ti:sapphire - a Way Towards Few Cycle PW Lasers," in Conference on Lasers and Electro-Optics, 5-10 June 2016, San Jose, USA, paper SM1M.2. 
URL: https://doi.org/10.1364/CLEO_SI.2016.SM1M.2

KE.3. V. Chvykov*, H. Cao, R. Nagymihaly, M. Kalashnikov, N. Khodakovskiy, K. Osvay, "New Generation of Ultra-High Peak and Average Power Laser Systems," in $25^{\text {th }}$ Annual International Laser Physics Workshop, 11-15 July 2016, Yerevan, Armenia, invited talk, paper S4.1.1.

URL: https://www.lasphys.com/workshops/lasphys16/program-seminar-4

KE.4. V. Chvykov*, H. Cao, R. Nagymihaly, M. Kalashnikov, N. Khodakovskiy, K. Osvay, "Extraction During Pumping for Thin Disc Ti:Sapphire Amplifiers (EDP-TD)," in 25 th Annual International Laser Physics Workshop, 11-15 July 2016, Yerevan, Armenia, paper S4.1.2.

URL: https://www.lasphys.com/workshops/lasphys16/program-seminar-4

KE.5. R. S. Nagymihaly*, H. Cao, M. Kalashnikov, N. Khodakovskiy, L. Ehrentraut, K. Osvay, V. Chvykov, "Proof-of-principle experiment on a Thin Disk Ti:Sapphire amplifier with Extraction During Pumping (EDP-TD)," in 7th EPS-QEOD Europhoton Conference, 21-26 August 2016, Vienna, Austria, paper SSL-3.7.

URL: http://2016.europhoton.org/files/europhoton7_book_print_v05.pdf

KE.6. H. Cao*, R. S. Nagymihaly, M. Kalashnikov, V. Chvykov, N. Khodakovskiy, K. Osvay, "Towards few cycle PW peak and kW average power Ti:Sapphire laser systems," in International Conference on Coherence and Nonlinear Optics / International Conference on Lasers, Applications, and Technologies, 26-30 September 2016, invited talk, paper IWB1.

URL: http://iconolat16.phys.msu.ru/ICONO_LAT-2016/Program_overview.html

KE.7. R. S. Nagymihaly*, H. Cao, M. Kalashnikov, N. Khodakovskiy, L. Ehrentraut, K. Osvay and V. Chvykov, "Thin Disk Ti:Sapphire amplifiers for Joule-class ultrashort pulses with high repetition rate," in SPIE Optics + Optoelectronics, 24-27 April 2017, Prague, Czech Republic, paper 10238-11.

DOI: $h$ ttp://dx.doi.org/10.1117/12.2265290

KE.8. H. Cao*, M. Kalashnikov, K. Osvay, N. Khodakovskiy, R. S. Nagymihaly, and V. Chvykov, "Active spectral pre-shaping with polarization encoded amplifiers," in SPIE Optics + Optoelectronics, 24-27 April 2017, Prague, Czech Republic, paper 10238-09.

DOI: http://dx.doi.org/10.1117/12.2264702

KE.9. R. S. Nagymihaly*, P. Jojart, A. Borzsonyi, K. Osvay, "Measurement of spectral phase noise in a cryogenically cooled Ti:Sa amplifier," in SPIE Optics + Optoelectronics, 24-27 April 2017, Prague, Czech Republic, paper 10238-12 (2017).

DOI: http://dx.doi.org/10.1117/12.2265281

KE.10. R. S. Nagymihaly, P. Jojart, A. Borzsonyi*, K. Osvay, "Spectral phase instabilities during amplification in Ti:Sapphire," in Conference on Lasers and Electro-Optics, 14-19 May 2017, San Jose, California, USA, paper SM3I.7.

DOI: https://doi.org/10.1364/CLEO SI.2017.SM3I.7

KE.11. V. Chvykov*, R. Nagymihaly, H. Cao, M. Kalashnikov, K. Osvay, "High Repetition Rate Thin Disk Ti:Sa Amplifiers for Sub-PW class Laser Systems," in Conference on Lasers and ElectroOptics, 14-19 May 2017, San Jose, California, USA, paper STu1O.5.

DOI: https://doi.org/10.1364/CLEO_SI.2017.STu1O.5 
KE.12. V. Chvykov*, R. Nagymihaly, H. Cao, M. Kalashnikov, and K. Osvay, "High Peak Power and Repetition Rate Laser Systems with Thin Disk Ti:Sa Amplifiers," in Frontiers in Optics 2017, 18-21 September 2017, Washington, D.C. USA, paper LW5F.2.

DOI: https://doi.org/10.1364/LS.2017.LW5F.2

KE.13. V. Chvykov*, R. Nagymihaly, H. Cao, M. Kalashnikov, K. Osvay, "Ti:Sapphire as Perspective Active Media for Thin Disk Lasers and Amplifiers," in Advanced Solid State Lasers Conference, 1-5 October 2017, Nagoya, Aichi, Japan, paper AW4A.2.

DOI: https://doi.org/10.1364/ASSL.2017.AW4A.2

KE.14. R. Nagymihaly, H. Cao, P. Jojart, M. Kalashnikov, A. Borzsonyi, V. Chvykov*, K. Osvay, "Carrier-Envelope Phase Stability in a Polarization-Encoded Ti:Sa amplifier," in Advanced Solid State Lasers Conference, 1-5 October 2017, Nagoya, Aichi, Japan, paper AW1A.5. DOI: https://doi.org/10.1364/ASSL.2017.AW1A.5

KE.15. R. S. Nagymihaly*, P. Jojart, A. Borzsonyi, H. Cao, M. Kalashnikov, V. Chyvkov, J. Limpert, T. Mocek, and K. Osvay, "Investigation of spectral phase stability issues in ultrafast laser systems by spectrally resolved interferometry," International Conference on Extreme Light, 69 November 2017, Szeged, Hungary.

URL: https://www.eli-alps.hu/indico/event/12/program

KE.16. M. Kalashnikov*, V. Chvykov, H. Cao, R. Nagymihaly, N. Khodakovskiy, "Future of Ti:Sapphire lasers: combining high peak and average power," International Conference on Extreme Light, 6-9 November 2017, Szeged, Hungary.

URL: https://www.eli-alps.hu/indico/event/12/program

KP.1. A. Borzsonyi, R. S. Nagymihály, P. Jojart, and K. Osvay*, "Carrier-Envelop Phase Noise of Ultrashort Pulses in a Ti:Sapphire Amplifier," in Conference on Lasers and Electro-Optics, 914 June 2013, San Jose, California, USA, paper JTh2A.15.

DOI: https://doi.org/10.1364/CLEO_QELS.2013.JTh2A.15

KP.2. A. Borzsonyi*, R. S. Nagymihály, P. Jójárt, and K. Osvay, "Carrier-Envelope Phase Noise Increment Due to Thermal Issues of a Ti:Sapphire-Based Amplifier," in Advanced Solid-State Lasers Congress, 27 October - 1 November 2013, Paris, France, paper JTh2A.18.

DOI: https://doi.org/10.1364/ASSL.2013.JTh2A.18

KP.3. A. Börzsönyi, R.S. Nagymihály, and K. Osvay, "Thermal Originated Drift and Noise of CarrierEnvelope Phase in Ti:Sapphire Based Amplifiers," in International Conference on Ultrahigh Intensity Lasers, 12-17 October 2014, Goa, India.

KP.4. A. Borzsonyi, R. S. Nagymihály*, and K. Osvay, "Drift and Noise of Carrier-Envelope Phase in Ti:Sapphire Based Ultrashort Pulse Amplifiers," in European Conference on Lasers and Electro-Optics - European Quantum Electronics Conference, 21-25 June 2015, Munich, Germany, paper CF_P_7.

URL: https://www.osapublishing.org/abstract.cfm?uri=CLEO Europe-2015-CF_P 7

KP.5. R. Nagymihály* and V. Chvykov, "Thermal Dynamics of Petawatt Class Ti:Sapphire EDP Thin Disk Amplifiers," in Advanced Solid State Lasers Conference, 4-9 October 2015, Berlin, Germany, paper ATu2A.40 (2015).

DOI: https://doi.org/10.1364/ASSL.2015.ATu2A.40 
KP.6. R.S. Nagymihaly, P. Jojart, A. Borzsonyi, and K. Osvay*, "Carrier Envelope Phase Noise of Laser Pulses Originating from Water Cooled and Cryogenically Cooled Ti:Sapphire Amplifiers," in International Conference on Extreme Light, 23-27 November 2015, Bucharest, Romania, paper 15.

KP.7. A. Andrásik*, P. Jojart, Sz. Toth, R.S. Nagymihály, A Börzsönyi, and K. Osvay, "Development of broadband ultrashort pulse amplifiers at $80 \mathrm{MHz}$," in International Conference on Extreme Light, 23-27 November 2015, Bucharest, Romania, paper 41.

KP.8. A. Andrásik*, P. Jójárt, Sz. Toth, R. S. Nagymihály, Á. Börzsönyi, K. Osvay, "10 W multipass Ti:S amplifier for $80 \mathrm{MHz}$ repetition rate," in 7th EPS-QEOD Europhoton Conference, 21-26 August 2016, Vienna, Austria, paper PO-1.29.

URL: http://2016.europhoton.org/files/europhoton7_book_print_v05.pdf

KP.9. Sz. Tóth, R. Flender, R. S. Nagymihály, P. Jójárt, A. Andrásik*, Á. Börzsönyi, K. Osvay, "Modelling and Development of an $80 \mathrm{MHz}$ Repetition Rate tuneable OPCPA system for InVivo Deep Brain Imaging Microscopy," in 7th EPS-QEOD Europhoton Conference, 21-26 August 2016, Vienna, Austria, paper PO-3.23.

URL: http://2016.europhoton.org/files/europhoton7_book_print_v05.pdf

KP.10. R. S. Nagymihaly, P. Jojart, A. Borzsonyi, K. Osvay*, "Spectral phase noise in a cryogenically cooled Ti:S amplifier," in International Conference on Ultrahigh Intensity Lasers, 11-16 September 2016, Montebello, Canada, paper M-P11.

URL: http://www.icuil2016.org/documentation/160829_program.pdf

KP.11. V. Chvykov*, H. Cao, R. Nagymihaly, M. Kalashnikov, N. Khodakovskiy, R. Glassock, L. Ehrentraut, M. Schnuerer, and K. Osvay, "High Repetition Rate for Ultra-High Peak Power Laser Systems" in Advanced Solid State Lasers Conference, 30 October-3 November 2016, Boston, Massachusetts, USA, paper JTu2A.2.

DOI: https://doi.org/10.1364/ASSL.2016.JTu2A.2

KP.12. P. Jójárt*, J. Csontos, Á. Börzsönyi, R. S. Nagymihály, T. Eidam, J. Limpert, K. Osvay, "Interferometric phase noise measurement of water-cooled mirrors for high average-power femtosecond lasers," in SPIE Optics + Optoelectronics, 24-27 April 2017, Prague, Czech Republic, paper 10238-38.

URL: $w$ ww.spie.org/Documents/ConferencesExhibitions/EOO17\%20Abstracts\%20lr.pdf

KP.13. A. Andrásik*, Sz. Toth, R.S. Nagymihály, P. Jojart, R. Flender, A Börzsönyi, K. Osvay, "Development of few cycle Ti:Sapphire and NOPA amplifiers at $80 \mathrm{MHz}$ repetition rate," in SPIE Optics + Optoelectronics, 24-27 April 2017, Prague, Czech Republic, paper 10238-36.

URL: WWW.spie.org/Documents/ConferencesExhibitions/EOO17\%20Abstracts\%201r.pdf

KP.14. R. S. Nagymihaly*, H. Cao, D. Papp, G. Hajas, M. Kalashnikov, K. Osvay, V. Chvykov, "Water-cooled Thin Disk Ti:Sapphire Amplifiers for kW Average Power," in European Conference on Lasers and Electro-Optics - European Quantum Electronics Conference, 25-29 June 2017, Munich, Germany, paper CA-P.28 (2017).

DOI: $\underline{\text { https://doi.org/10.1109/CLEOE-EQEC.2017.8086323 }}$

KP.15. H. Cao*, M. Kalashnikov, K. Osvay, N. Khodakovskiy, R. Nagymihaly, V. Chvykov, "Active spectral shaping with polarization encoding of chirped pulses in Ti:sapphire amplifiers" in 
European Conference on Lasers and Electro-Optics and European Quantum Electronics Conference, 25-29 June 2017, Munich, Germany, paper CA_P_17.

DOI: https://doi.org/10.1109/CLEOE-EQEC.2017.8086312

KP.16. R. Nagymihaly*, H. Cao, P. Jojart, M. Kalashnikov, A. Borzsonyi, V. Chvykov, K. Osvay, "Measurement of the Carrier-Envelope Phase Noise in a Polarization-Encoded Ti:Sapphire Amplifier," in 14th International Conference on Multiphoton Processes, 24-27 September 2017, Budapest, Hungary, paper P48.

URL: https://indico.cern.ch/event/633926/attachments/1448419/2390002/ICOMP_ProgramDraft.pdf

KP.17. R. S. Nagymihaly, P. Jojart, A. Borzsonyi*, H. Cao, M. Kalashnikov, V. Chvykov, and K. Osvay, „Spectral phase noise upon amplification in Ti:Sapphire: effects of cooling and polarization encoding," in Ultrafast Optics XI, 8-13 October 2017, Jackson Hole, Wyoming, USA, paper P1.4.

URL: http://ultrafastoptics2017.org/content/3-schedule/2-full-program/ufo_xi_program.pdf

\section{X.4. Magyar konferencia prezentációk}

MP - magyar poszter, * - elöadó

MP.1. Börzsönyi Ádám, Nagymihály Roland Sándor*, Jójárt Péter, Osvay Károly, "Ultrarövid fényimpulzusok Ti:S erősítőben fellépő vivő-burkoló fázis zaja," Magyar Fizikus Vándorgyülés, 2013 augusztus 21-24, Debrecen, Magyarország, 20.4 prezentáció.

URL: http://w3.atomki.hu/Magyar_Fizikus_Vandorgyules_2013/Kivonatok_konyve.pdf

MP.2. Andrásik Attila, Jójárt Péter, Toth Szabolcs, Nagymihály Roland Sándor*, Börzsönyi Ádám, Osvay Károly, “10 W-os többpasszos Ti:S erősítő 80 MHz-es ismétlődési frekvencián,” Magyar Fizikus Vándorgyülés, 2016 augusztus 24-27, Szeged, Magyarország.

URL: http://titan.physx.u-szeged.hu/fizikus_vandorgyules_2016/node/6\#poszterek

MP.3. H. Cao*, M. Kalashnikov, K. Osvay, Nikita Khodakovskiy, Roland S. Nagymihaly and V. Chvykov, "Polarization Encoded Chirped Pulse Amplification in Ti:Sapphire - a Way towards Few Cycle PW Lasers,” Magyar Fizikus Vándorgyülés, 2016 augusztus 24-27, Szeged, Magyarország.

URL: http://titan.physx.u-szeged.hu/fizikus_vandorgyules_2016/node/6\#poszterek

MP.4. P. Jójárt*, J. Csontos, Á. Börzsönyi, R. S. Nagymihály, T. Eidam, J. Limpert, K. Osvay, "Vízhütéses optomechanikai eszközök fáziszajának mérése," Magyar Fizikus Vándorgyülés, 2016 augusztus 24-27, Szeged, Magyarország.

URL: http://titan.physx.u-szeged.hu/fizikus_vandorgyules_2016/node/6\#poszterek

MP.5. Kurucz Máté*, Börzsönyi Ádám, Kovács Máté, Nagymihály Roland, Osvay Károly, “Az SZTE TeWaTi femtoszekundumos lézerrendszer vivő-burkoló fáziscsúszásának mérése és stabilizálása," Magyar Fizikus Vándorgyülés, 2016 augusztus 24-27, Szeged, Magyarország.

URL: http://titan.physx.u-szeged.hu/fizikus_vandorgyules_2016/node/6\#poszterek

MP.6. R. S. Nagymihály*, Á. Börzsönyi, P. Jójárt, K. Osvay, "Spektrális- és vivő-burkoló fáziszaj a víz- és kriogenikus hütésủ Ti:Sa erősítőkben," Magyar Fizikus Vándorgyülés, 2016 augusztus 24-27, Szeged, Magyarország.

URL: http://titan.physx.u-szeged.hu/fizikus_vandorgyules_2016/node/6\#poszterek 
MP.7. Sz. Toth*, R. S. Nagymihaly, P. Jojart, R. Flender, A Andrásik, A Börzsönyi, K. Osvay, " 80 MHz ismétlési frekvencián müködő optikai parametrikus erősítő fejlesztése," Magyar Fizikus Vándorgyülés, 2016 augusztus 24-27, Szeged, Magyarország.

URL: http://titan.physx.u-szeged.hu/fizikus_vandorgyules_2016/node/6\#poszterek 


\section{Függelék}

\section{XI.1. Hőterjedés folyadékokban és szilárdtestekben}

Numerikus szimulációim során a Ti:Sa kristályban, valamint a folyadékban végbemenő hőterjedés leírására a stacionárius hőterjedési egyenletet használtam fel. Ehhez elsőként tekintsük a folyadékban, azaz a hütővízben lejátszódó hőterjedést, amit a

$$
\rho C_{p}\left(\frac{\partial T}{\partial t}+\mathbf{u} \cdot \nabla T\right)+\nabla \cdot\left(\mathbf{q}+\mathbf{q}_{r}\right)=\alpha_{p} T\left(\frac{\partial \rho}{\partial t}+\mathbf{u} \cdot \nabla \rho\right)+\boldsymbol{\tau}: \nabla \mathbf{u}+Q
$$

hőterjedési egyenlet ír le [184,201], ahol $\rho$ a folyadék sürüsége, $C_{p}$ az állandó nyomáson mért fajhője, u a sebességvektor,

$$
\mathbf{q}=-k_{f} \nabla T
$$

a konduktív höáram (W/m² egységben), amelyben $k_{f}$ a folyadék hővezetési együtthatója, $T$ az abszolút hőmérséklet, továbbá $\mathbf{q}_{r}$ a sugárzás általi hőáram,

$$
\alpha_{p}=-\frac{1}{\rho} \frac{\partial \rho}{\partial T}
$$

az állandó nyomáson mért hőtágulási együttható, $\boldsymbol{\tau}$ viszkózus feszültség tenzor, végül pedig $Q$ a Ti:Sa kristályból hővezetés révén átadódó hőmennyiség. A (XI.1.) egyenlet jobb oldalának első tagja a nyomásváltozások által végzett

$$
Q_{p}=\alpha_{p} T\left(\frac{\partial \rho}{\partial T}+\mathbf{u} \cdot \nabla p\right)
$$

munka, amely az adiabatikus összenyomás illetve termoakusztikus effektusok hatását veszi figyelembe. A (XI.1) egyenlet jobb oldalának második tagja pedig a

$$
Q_{v d}=\boldsymbol{\tau}: \nabla \mathbf{u}
$$

un. viszkózus disszipáció eredményeként létrejövő hőmennyiség, amely a viszkózus feszültség és a sebességtér tenzori szorzataként áll elö. Tekintettel arra, hogy a hőterjedési probléma stacionárius megoldását keressük, az (XI.1) egyenlet jelentősen egyszerüsödik, hiszen az bal oldal első tagja az időfüggés hiánya miatt eltünik, valamint a modellben nem veszünk figyelembe sugárzás alapú höáramot, így a

$$
\rho C_{p} \mathbf{u} \cdot \nabla T+\nabla \cdot \mathbf{q}=Q+Q_{p}+Q_{v d}
$$

egyenletet kapjuk a folyadékban történő hőáramlásra.

Áttérve a szilárdtestben, azaz a Ti:Sa kristályban bekövetkező hőterjedésre, a

$$
\rho_{s} C_{p, s}\left(\frac{\partial T_{s}}{\partial t}+\mathbf{u}_{t r} \cdot \nabla T_{s}\right)+\nabla \cdot\left(\mathbf{q}_{s}+\mathbf{q}_{r, s}\right)=-\boldsymbol{\alpha} T_{s}: \frac{d S}{d t}+Q_{s}
$$

kifejezést nyerjük, ahol $\rho_{s}$ a kristály sürüsége, $C_{p, s}$ az állandó nyomáson mért fajhője, $T_{S}$ a kristályban mért abszolút hőmérséklet, $\mathbf{u}_{t r}$ a transzlációs mozgás sebességvektora, $\mathbf{q}_{s}$ a kristályban kialakuló konduktív hőáram, $\mathbf{q}_{r, s}$ a sugárzásból származó hőáram, továbbá $\boldsymbol{\alpha}$ a hőtágulási együttható, $S$ a második 
Piola-Kirchhoff feszültség tenzor, és végül $Q_{s}$ a kristályban abszorbeált pumpaimpulzusok energiájából disszipálódott hőmennyiség (W/m³ egységben) [184,202]. A pumpaimpulzusok hőterhelését egyoldali pumpálás esetén a

$$
\begin{aligned}
& Q_{f 1}=P \cdot \eta \cdot e^{-\beta y} \cdot \beta \cdot F_{S G}, \\
& Q_{r 1}=P \cdot \eta \cdot e^{-\beta L} \cdot e^{-\beta(L-y)} \cdot \beta \cdot F_{S G}, \\
& Q_{f 2}=P \cdot \eta \cdot\left(e^{-\beta L}\right)^{2} \cdot e^{-\beta y} \cdot \beta \cdot F_{S G}, \\
& Q_{r 2}=P \cdot \eta \cdot\left(e^{-\beta L}\right)^{3} \cdot e^{-\beta(L-y)} \cdot \beta \cdot F_{S G},
\end{aligned}
$$

kifejezések összegével adtam meg az aktív tükör elrendezésű erősítők esetén, ahol a $f 1$ és $f 2$ indexek a kristályon való elülső felület felőli áthaladásokra, addig az $r l$ és $r 2$ indexek pedig a hátulsó felületről való reflexiókra utalnak, illetve $P$ a pumpaimpulzusok átlagteljesítménye, $\eta$ a hődisszipáció hatásfoka, $\beta$ a Ti:Sa kristály abszorpciós együtthatója, $L$ a kristály vastagsága, $y$ a transzverzális irányú térkoordináta, $F_{S G}$ pedig a térbeli profilt meghatározó, magasrendủ Super-Gauss függvény. A kétoldali pumpálás esetén a (XI.8.) kifejezések alakja kis mértékben módosul, amely alapján a

$$
\begin{aligned}
& Q_{f 1}=\frac{P}{2} \cdot \eta \cdot e^{-\beta y} \cdot \beta \cdot F_{S G}, \\
& Q_{b 1}=\frac{P}{2} \cdot \eta \cdot e^{-\beta(L-y)} \cdot \beta \cdot F_{S G}, \\
& Q_{f 2}=\frac{P}{2} \cdot \eta \cdot e^{-\beta L} \cdot e^{-\beta y} \cdot \beta \cdot F_{S G}, \\
& Q_{b 2}=\frac{P}{2} \cdot \eta \cdot e^{-\beta L} \cdot e^{-\beta(L-y)} \cdot \beta \cdot F_{S G}, \\
& Q_{f 3}=\frac{P}{2} \cdot \eta \cdot\left(e^{-\beta L}\right)^{2} \cdot e^{-\beta y} \cdot \beta \cdot F_{S G}, \\
& Q_{b 3}=\frac{P}{2} \cdot \eta \cdot\left(e^{-\beta L}\right)^{2} \cdot e^{-\beta(L-y)} \cdot \beta \cdot F_{S G},
\end{aligned}
$$

kifejezések összegeként kapható a kristályt fütő teljesítmény, ahol $f 1-f 3$ és $b 1-b 3$ indexek az elülső oldali és hátulsó oldali átmenetekre utalnak.

A (XI.7) egyenlet jobb oldalának első tagja az ún. termoelasztikus csillapítás, amely a szilárdtestben létrejövő termoelasztikus effektusok hatását foglalja magában, és a

$$
Q_{t e}=-\boldsymbol{\alpha} T: \frac{d S}{d t}
$$

alakban áll elö. Az (XI.7) kifejezést az ún. lokális hőegyensúly egyenletből lehet megkapni, amellyel kapcsolatban az olvasó a [202] forrásmunkában tájékozódhat. Ismételten, mivel stacionárius megoldást keresünk, az időfüggő tagok kiesnek az (XI.7) egyenletből, a sugárzásból származó hőáram a modellben nincs figyelembe véve, valamint a sebességvektor minden komponense a kristályra nézve nulla. Ennek megfelelően a stacionárius esetre vonatkozó hőterjedési egyenlet a

$$
\nabla \cdot \mathbf{q}_{s}=Q_{s}
$$

alakot veszi fel, ahol

$$
\mathbf{q}_{s}=-k_{s} \nabla T_{s}
$$


a szilárdtestben kialakuló hőáram, és $k_{s}$ a test hővezetési együtthatója. A hőterjedéssel kapcsolatos, rendkívül hasznos gyakorlat orientált példák találhatóak a [197] forrásban.

\section{XI.2. Turbulens folyadékáramlás SST modellje}

A turbulens folyadékáramlások szimulációja rendkívül sokrétủ probléma, alkalmazástól függően szokás a felhasznált modellt megválasztani, tekintettel a számítási igényre és a megoldáshoz szükséges időre. Kétdimenziós szimulációim során az áramlási csatorna és a Ti:Sa kristály érintkezési felületénél a hőkicsatolás pontos meghatározása miatt a határrétegeknél jól működő standard $k-\omega$, valamint a határrétegtől távoli régiókban optimális $k-\varepsilon$ modellek hasznos tulajdonságait egyesítő SST modellt választottam a hütővíz áramlásának kiszámítására. Az előbbi két modell részletes leírásával kapcsolatban a [196] munkában tájékozódhatunk.

Az SST modell a Reynolds-átlagolású Navier-Stokes (Reynolds-averaged Navier-Stokes, RANS) egyenleteken alapuló turbulencia modellek közé tartozik. A COMSOL Multiphysics szoftverben az eredeti SST alapmodell egy módosított változata került beépítésre, amely A szállítási egyenletek az SST modell esetén a $k$ turbulens kinetikus energiára, illetve az $\omega$ fajlagos disszipációs sebességre vonatkozóan összenyomhatatlan áramlásra a

$$
\begin{gathered}
\rho \frac{\partial k}{\partial t}+\rho(\mathbf{u} \cdot \nabla) k=\tilde{P}_{k}-\rho \beta^{*} k \omega+\nabla \cdot\left[\left(\mu+\sigma_{k} \mu_{T}\right) \nabla k\right], \\
\rho \frac{\partial \omega}{\partial t}+\rho(\mathbf{u} \cdot \nabla) \omega=\tilde{P}_{k} \rho \frac{\gamma}{\mu_{T}}-\rho \beta \omega^{2}+\nabla\left[\left(\mu+\sigma_{\omega} \mu_{T}\right) \nabla \omega\right]+2\left(1-F_{1}\right) \frac{\rho \sigma_{\omega 2}}{\omega} \nabla \omega \nabla k
\end{gathered}
$$

alakban írhatóak fel, ahol $\rho$ a folyadék sürúsége, $\mu$ a dinamikai viszkozitása, illetve $\mathbf{u}$ a sebességvektor, $F_{1}$ pedig egy ún. keverési függvény, amelyre érvényes az

$$
\begin{aligned}
& F_{1}=\tanh \left(\Theta_{1}^{4}\right), \\
& \Theta_{1}=\min \left[\max \left(\frac{\sqrt{k}}{\beta^{*} \omega l_{w}^{2}}, \frac{500 \mu}{\rho \omega l_{w}^{2}}\right), \frac{4 \rho \sigma_{\omega 2} k}{C D_{k \omega} l_{w}^{2}}\right], \\
& C D_{k \omega}=\max \left(\frac{2 \rho \sigma_{\omega 2}}{\omega} \nabla \omega \cdot \nabla k, 10^{-10}\right),
\end{aligned}
$$

és amely értéke nulla a falaktól távol, míg értéke egyhez tart a határrétegben [184,194,195]. Az (XI.15) kifejezésben szereplő $l_{w}$ a legközelebbi faltól mért távolság. A mindkét egyenletben előforduló $\mu_{T}$ turbulens viszkozitást a

$$
\mu_{T}=\frac{\rho a_{1} k}{\max \left(a_{1} \omega, S F_{2}\right)}
$$

kifejezés adja meg, ahol $F_{2}$ egy újabb keverési függvény, amelyre

$$
\begin{aligned}
& F_{2}=\tanh \left(\Theta_{2}^{2}\right), \\
& \Theta_{2}=\max \left(\frac{2 \sqrt{k}}{\beta^{*} \omega l_{w}^{2}}, \frac{500 \mu}{\rho \omega l_{w}^{2}}\right),
\end{aligned}
$$

valamint 


$$
S=\sqrt{2 \mathbf{S}: \mathbf{S}},
$$

amelyben $S$ a nyírási ráta invariáns mértéke. A turbulencia felhalmozódását a stagnáló régiókban egy produkciós függvény korlátozza, amit a

$$
\tilde{P}_{k}=\min \left(P_{k}, 10 \cdot \beta^{*} k \rho \omega\right)
$$

kifejezéssel definiálunk, amelyben $P_{k}$ a

$$
P_{k}=\mu_{T}\left\{\nabla \mathbf{u}:\left[\left(\nabla \mathbf{u}+(\nabla \mathbf{u})^{T}\right)\right]\right\}
$$

formulával van definiálva. A modellben szereplö $\phi$ konstansokat a nekik megfelelő $k-\varepsilon$ és $k-\omega$ modellek $\phi_{1}$ és $\phi_{2}$ konstansaiból a

$$
\phi=\phi_{1} F_{1}+\phi_{2}\left(1-F_{1}\right), \phi=\beta, \alpha, \sigma_{k}, \sigma_{\omega}
$$

keverési függvény segítségével állíthatjuk elö. Az SST modellben szereplő konstansok a következöek: $\beta^{*}=0,31, \gamma_{1}=5 / 9, \beta_{1}=3 / 40, \sigma_{k 1}=0,85, \sigma_{\omega 1}=0,5, \gamma_{2}=0,44, \beta_{2}=0,0828, \sigma_{k 2}=1, \sigma_{\omega 2}=$ $0,856[184,194]$. 